UNIVERSIDADE DE SÃO PAULO

FACULDADE DE ECONOMIA, ADMINISTRAÇÃO E CONTABILIDADE DEPARTAMENTO DE ADMINISTRAÇÃO PROGRAMA DE PÓS-GRADUAÇÃO EM ADMINISTRAÇÃo

PRÁTICAS ALTERNATIVAS EM GESTÃO DE PESSOAS:

ASTROLOGIA, FENG SHUI, GRAFOLOGIA, NUMEROLOGIA, RADIESTESIA, SHIATSU

METAFÍSICA OU NOVAS ABORDAGENS EM ADMINISTRAÇÃO?

Elenir Honorato Vieira

Orientadora: Profa. Dra. Ana Cristina Limongi-França

SÃO PAULO 
Prof. Dr. Adolpho Jose Melfi Reitor da Universidade de São Paulo

Profa. Dra. Maria Tereza Leme Fleury Diretora da Faculdade de Economia, Administração e Contabilidade

Prof. Dr. Eduardo Pinheiro Gondim de Vasconcellos Chefe do Departamento de Administração

Prof. Dr. Isak Kruglianskas Coordenador do Programa de Pós-Graduação em Administração 
ELENIR HONORATO VIEIRA

\title{
PRÁTICAS ALTERNATIVAS EM GESTÃO DE PESSOAS: \\ ASTROLOGIA, FENG SHUI, GRAFOLOGIA, NUMEROLOGIA, RADIESTESIA, SHIATSU \\ METAFÍSICA OU NOVAS ABORDAGENS EM ADMINISTRAÇÃO?
}

\begin{abstract}
Tese apresentada à Faculdade de Economia, Administração e Contabilidade da Universidade de São Paulo, como parte dos requisitos para obtenção do Título de Doutora em Administração de Empresas.
\end{abstract}

Orientadora Profa.Dra. Ana Cristina Limongi-França

SÃo PAULO 
Tese defendida e aprovada no Departamento de Administração da Faculdade de Economia, Administração e Contabilidade da Universidade de São Paulo - Programa de Pós-Graduação em Administração, pela seguinte banca examinadora:

FICHA CATALOGRÁFICA

Elaborada pela Seção de Processamento Técnico do SBD/FEA/USP

Vieira, Elenir Honorato

Práticas alternativas em gestão de pessoas : astrologia, feng shui, grafologia, numerologia, radiestesia, shiatsu. Ficção ou novas abordagens e administração ? / Elenir Honorato Vieira. São Paulo, 2005.

219 p.

Tese (Doutorado) - Universidade de São Paulo, 2005.

Bibliografia.

1. Qualidade de vida no trabalho 2. Seleção de pessoal 3. Astrologia 4. Aromaterapia I. Universidade de São Paulo. Faculdade de Economia, Administração e Contabilidade. II. Título.

$$
\text { CDD - 306.361 }
$$


Para

Minha filha, Ana Beatriz, Minha mãe, Settimia, Meu pai, Evilazio (in memorian) 


\section{AGRADECIMENTOS}

Quando a Profa. Dra. Rosa Maria Fischer, minha orientadora no mestrado em Administração de Empresas, colocou como um desafio a seleção para o doutorado, fiquei muito insegura: ser mestre é uma honra, mas teve um alto custo: por isso, buscar o doutorado parecia algo muito além das minhas possibilidades. Quando fui aprovada, tinha certo que ela seria minha orientadora, mas, sabiamente, ela recusou meu pedido. Agradeço a ela porque, hoje, tenho claro que sua decisão possibilitou que eu desatasse as amarras e pudesse caminhar com mais segurança.

Na busca por um orientador, que durou mais de um ano, tive a honra de, finalmente, ser aceita pela Profa. Dra. Ana Cristina Limongi-França. Mas a espera foi completamente recompensada: mais do que orientadora, a professora Ana tem sido minha amiga e, mais do que amiga, é a responsável por permitir que eu dê vazão a um antigo desejo: realizar um estudo diferente, provocador e instigante! Como agradecer a alguém que abre espaço para a realização de um sonho? Obrigada, professora!

Quero também render minha homenagem às pessoas que entrevistei e que são diretamente responsáveis pela conclusão deste estudo: especialistas e gestores das empresas que, gentilmente, abriram as portas de suas casas, de suas empresas e de suas vidas para me apoiar nesta empreitada.

Finalmente, quero agradecer às pessoas que estão na minha vida fora dos bancos escolares. $\mathrm{O}$ apoio afetivo que delas recebi possibilitou-me concluir este processo: minhas amigas Christina Andrews e Maria Aparecida Gamito da Silva; meus queridos José Genivaldo da Silva e Eva Freitas da Cruz; minha filha, Ana Beatriz Honorato Vieira; minha mãe, Settimia Borgiani Vieira; e meus irmãos Lourival, Solange, Ivani e Elza. 


\section{RESUMO}

As mudanças pela quais vem passando a área de gestão de pessoas têm suscitado o desenvolvimento de novas práticas, algumas ainda não validadas pela ciência, como é o caso da grafologia e do shiatsu e, outras, consideradas "ocultas" e, na melhor das hipóteses, metafísica, por sua origem mística, e que, alguns anos atrás, seria impensável o seu emprego como ferramentas em gestão empresarial, dentre elas a astrologia, a numerologia, o feng shui e a radiestesia. Este estudo identificou, descreveu e consolidou os dados de empresas que aplicam uma ou mais dessas práticas, revelando suas expectativas, quando optam por utilizálas e os resultados alcançados. O referencial teórico, que deu sustentação à pesquisa, pautouse na dimensão psíquica, através da análise da psicodinâmica organizacional e da psicologia analítica de Jung, na dimensão sociológica, através da cultura organizacional, na dimensão holística, que incorporou a perspectiva espiritual, e na dimensão administrativa, via análise das mudanças na gestão de pessoas e qualidade de vida no trabalho. Abordou-se ainda, de forma resumida, informações acerca das principais práticas alternativas. A metodologia de pesquisa consistiu de levantamentos quantitativo e qualitativo em empresas localizadas no eixo São Paulo/Rio de Janeiro, com o aprofundamento do estudo através da análise de multicasos. Foram entrevistados especialistas que atuam como consultores externos e gestores de 11 empresas de distintos portes e segmentos de atuação, que utilizam uma ou mais dessas ferramentas. Concluiu-se, dentre outros aspectos, que práticas alternativas são adotadas por diversos tipos, segmentos e portes de empresas, na maior parte das vezes, por definição da alta direção, e apenas em alguns casos, por iniciativa da área de recursos humanos. 


\begin{abstract}
The changes undergone by the personnel management area have given cause to the development of new practices, some of them still to be scientifically validated, such as graphology and shiatsu, others labeled as "occultism" and, on the best assumption, metaphysics because of their mystical origin, as for instance astrology, numerology, feng shui and radiesthesy. Years ago it would be unthinkable their use as a managerial tool. This study has identified, described and consolidated the data of firms which apply one or more of these practices, disclosing their expectations when they make an option for their use as well as the results obtained. The theoretical framework that has given support for the research was based on the psychical dimension, through the organizational psychodynamic analysis and Jung's analytical psychology, on the sociological dimension, through the organizational culture, on the holistic dimension that has incorporated the spiritual prospect, and on the administrative dimension, through analysis of the changes in the personnel management and in the life quality in the workplace. In a summarized manner, information about the main alternative practices was also given. The research methodology consisted of quantitative and qualitative surveys in firms located around the São Paulo/Rio de Janeiro axis, with a deepening of the study through multicase analysis. Interviews have been made with specialists who act as external consultants and managers of 11 firms of various sizes and market segments that use one of these tools. One of the conclusions reached is that alternative practices are adopted by firms of various types, sizes and market segments, in most cases by definition of higher management, and, just in a few cases, by initiative of the human resource area.
\end{abstract}




\section{SUMÁRIO}

Página

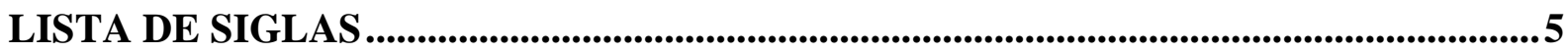

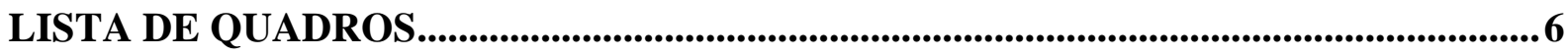

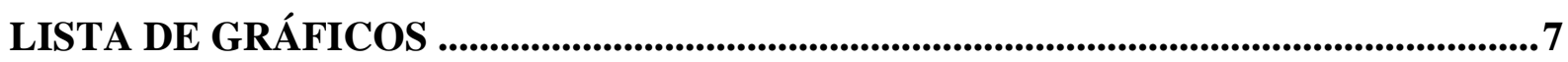

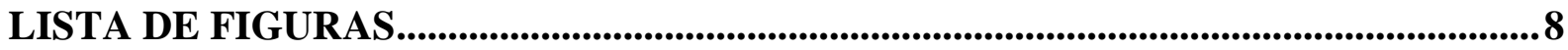

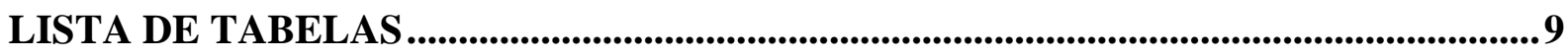

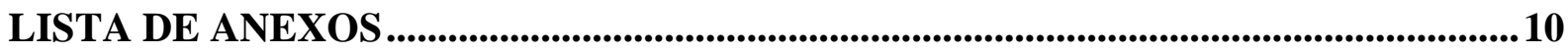

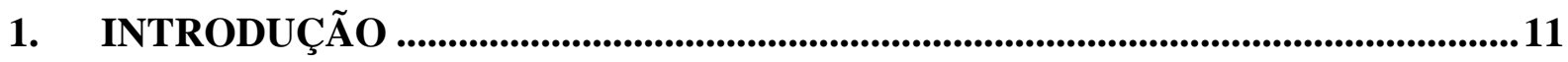

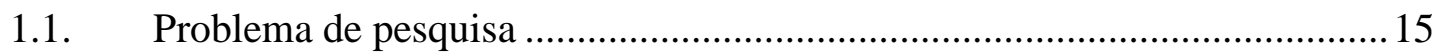

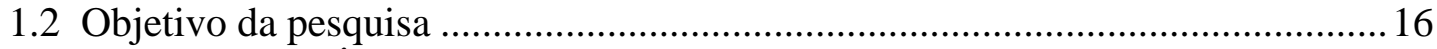

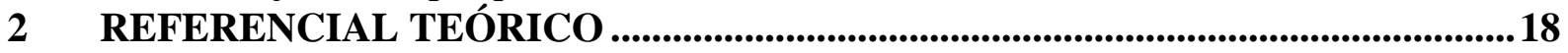

2.1 Abordagens conceituais utilizadas na pesquisa.............................................. 18

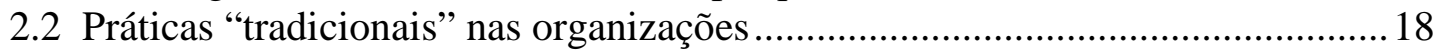

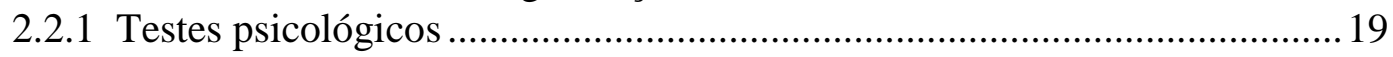

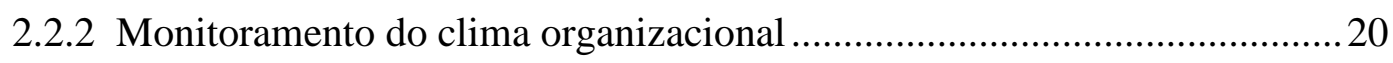

2.2.3 Avaliação de desempenho ................................................................ 21

2.3 O estudo das práticas nas áreas do conhecimento .............................................21

2.4 A dimensão psíquica e a teoria das organizações................................................23

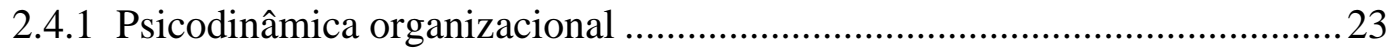

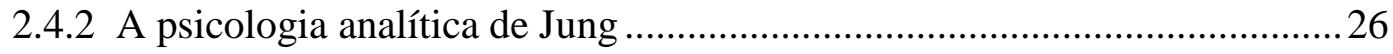

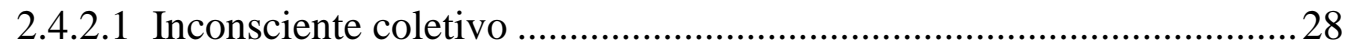

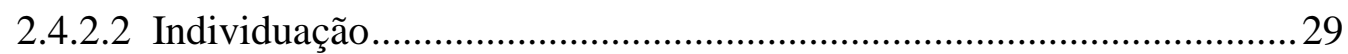

2.4.2.3 O inconsciente coletivo e a individuação no ambiente empresarial ....30

2.4.3 A psique e o alternativo ......................................................................... 31

2.5 A dimensão sociológica, o alternativo e a teoria das organizações..................... 31

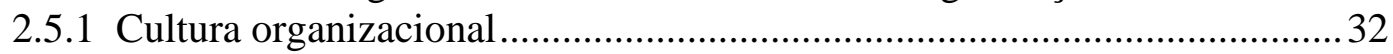

2.5.1.1 Diversidade e cultura organizacional.................................................. 33

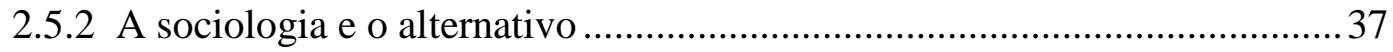

2.6 A dimensão holística na teoria das organizações ................................................ 37

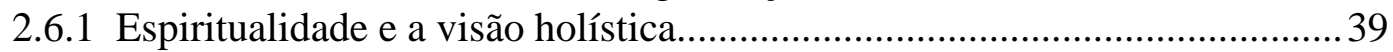

2.7 A dimensão da administração e a teoria das organizações................................. 40

2.7.1 Gestão de pessoas ................................................................................. 41

2.7.1.1 Organização por processos ........................................................ 41

2.7.1.2 Administração Estratégica de Recursos Humanos (AERH) ................ 41

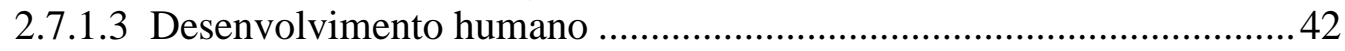

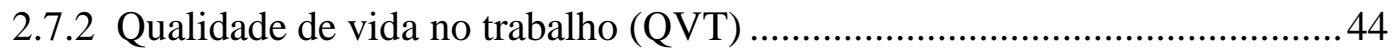




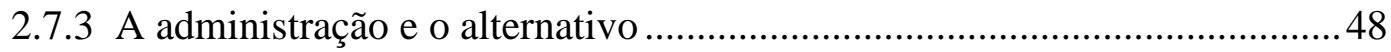

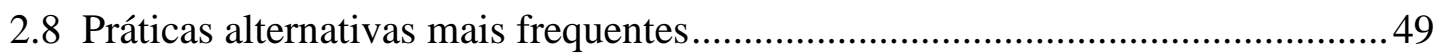

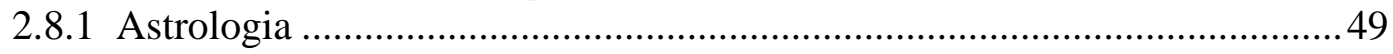

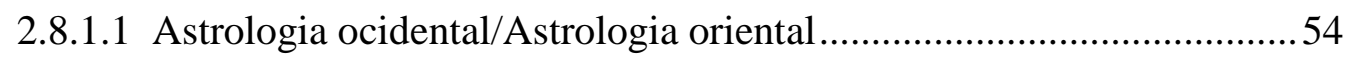

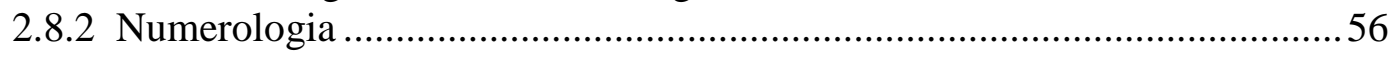

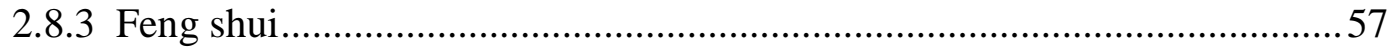

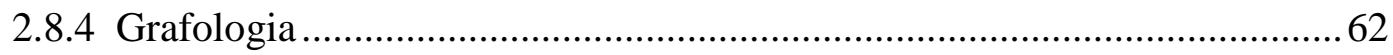

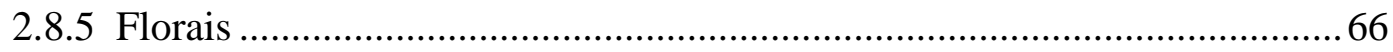

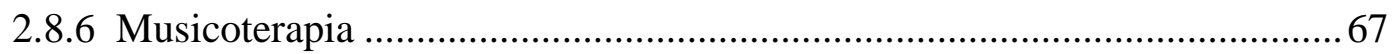

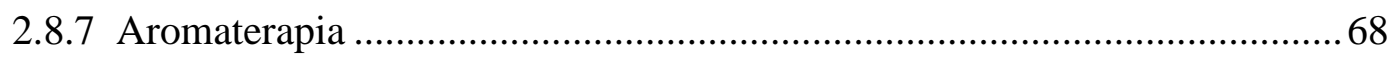

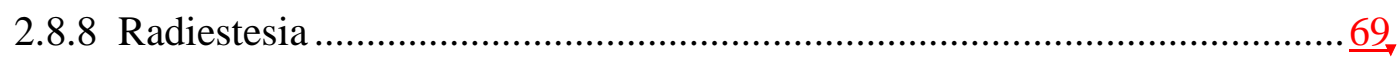

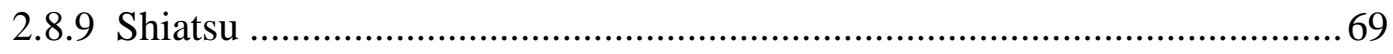

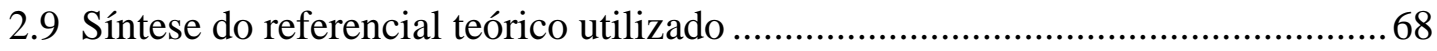

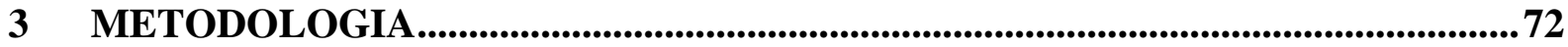

3.1 A importância do modelo metodológico …......................................................... 72

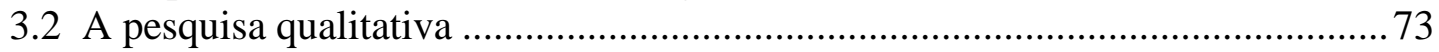

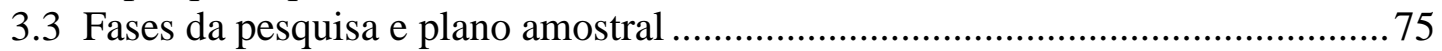

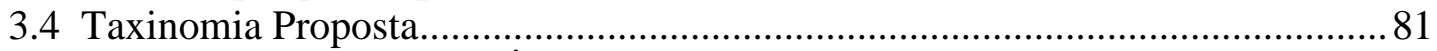

4 PESQUISA DE CAMPO E ANÁLISE DOS DADOS ..........................................82

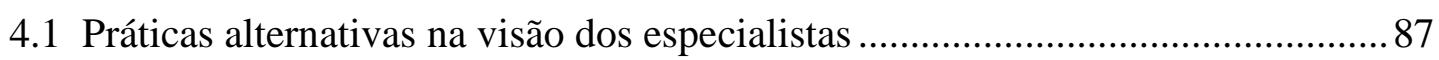

4.1.1 Trajetória de vida dos especialistas ...................................................... 90

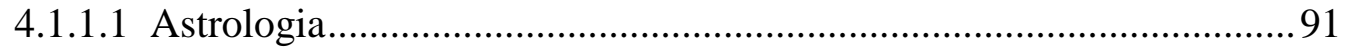

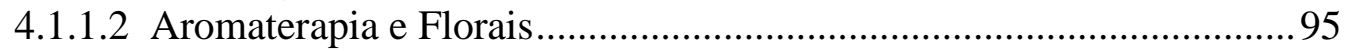

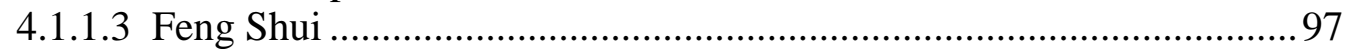

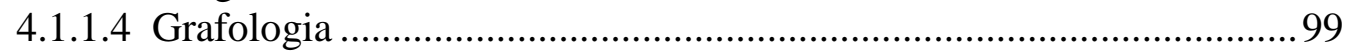

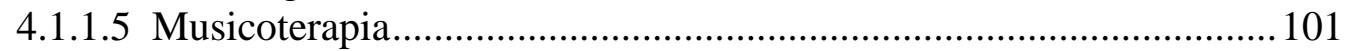

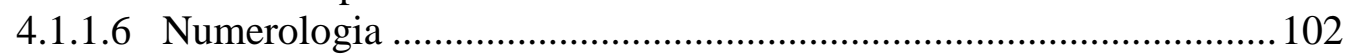

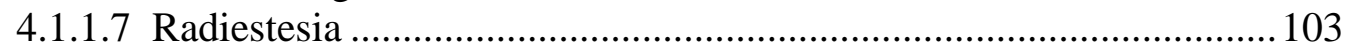

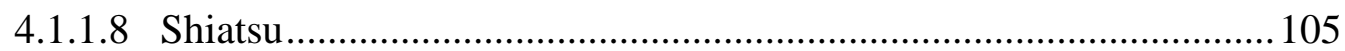

4.1.2 Resultados obtidos com a aplicação das práticas alternativas, na visão dos

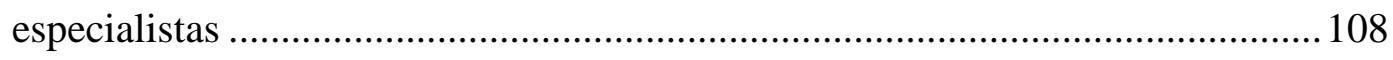

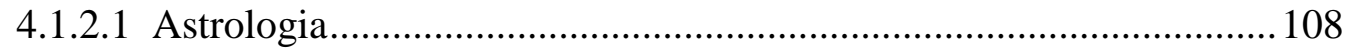

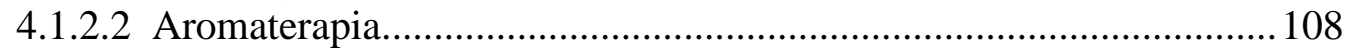

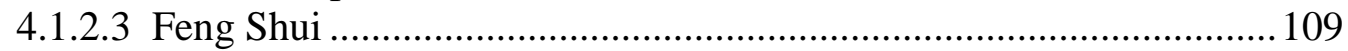

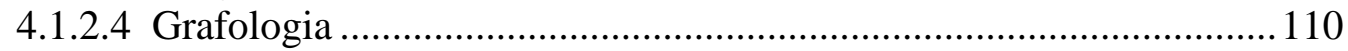

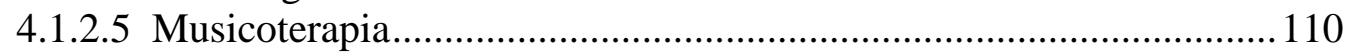

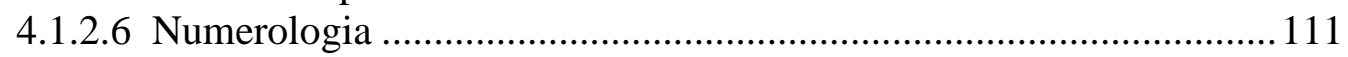

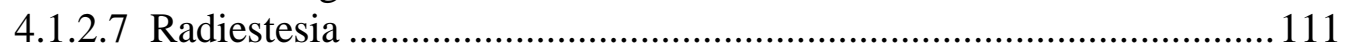

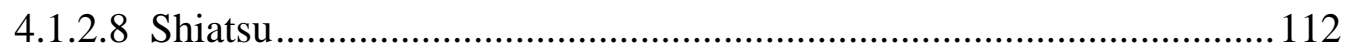

4.1.3 Vantagens e desvantagens das práticas alternativas, quando comparadas às

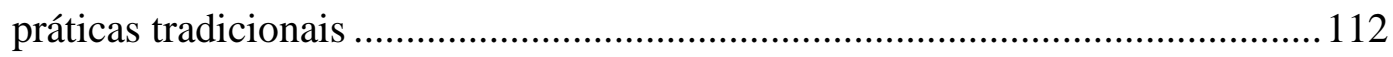

4.1.4 Como as práticas alternativas são aplicadas .......................................... 116 


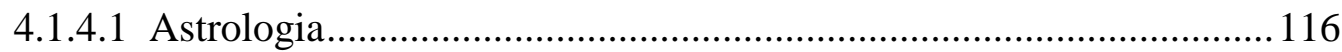

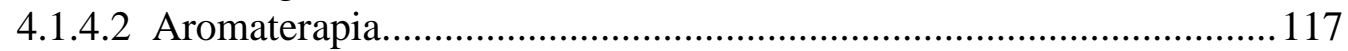

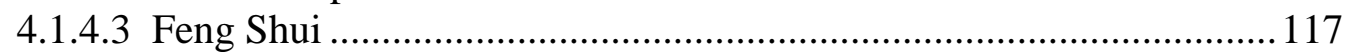

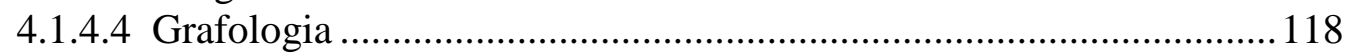

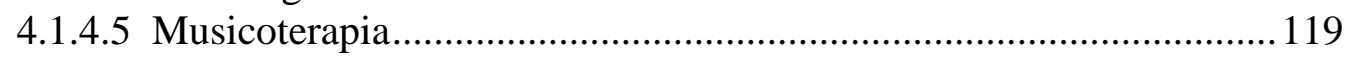

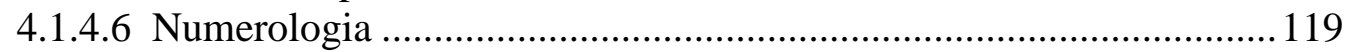

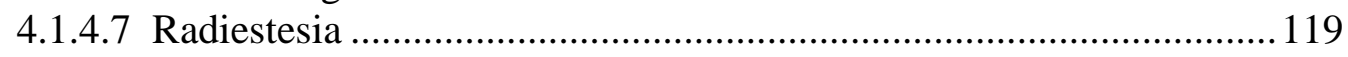

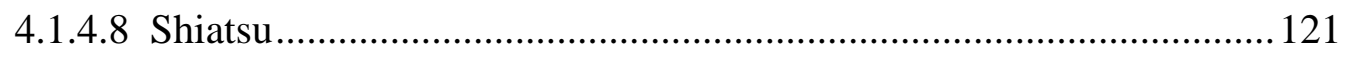

4.1.5 Aceitação das práticas alternativas em empresas .................................... 121

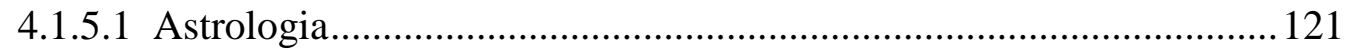

4.1.5.2 Aromaterapia/Essências Florais...................................................... 122

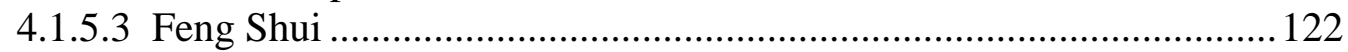

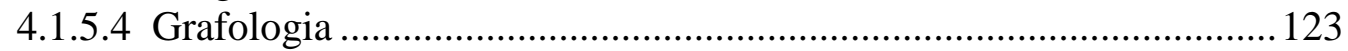

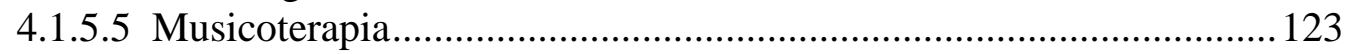

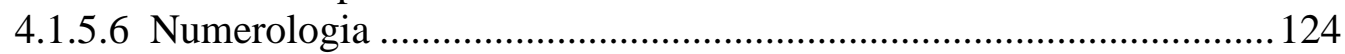

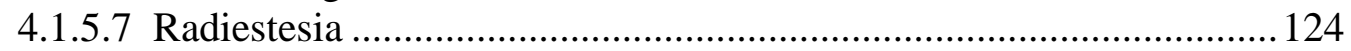

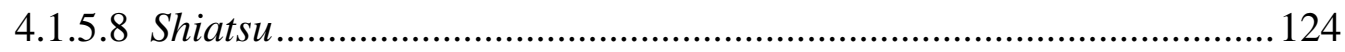

4.1.6 Relação entre visão de mundo/sociedade, valores organizacionais e a aceitação/utilização de práticas alternativas ..................................................... 125

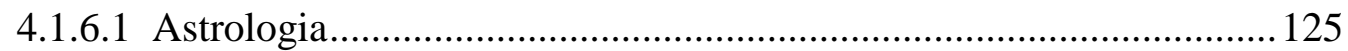

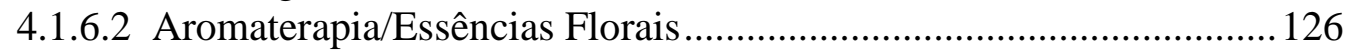

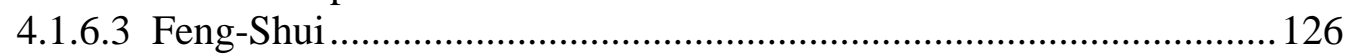

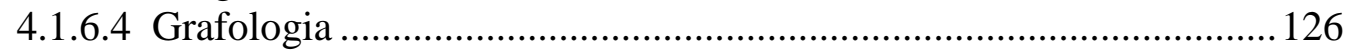

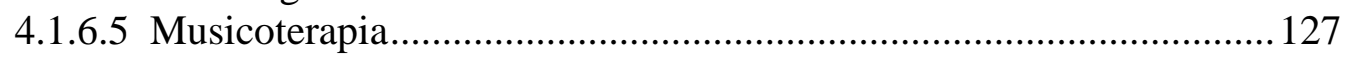

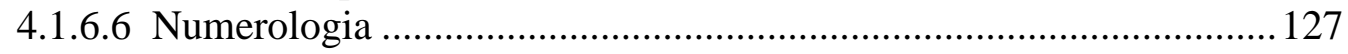

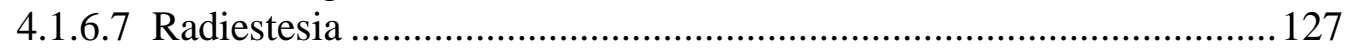

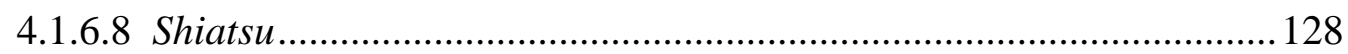

4.1.7 Aceitação ou discordância dos empregados .......................................... 128

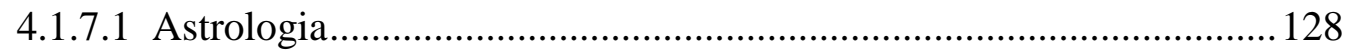

4.1.7.2 Aromaterapia/Essências Florais....................................................... 129

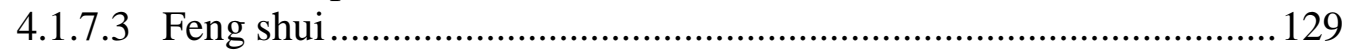

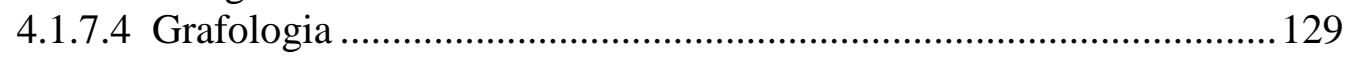

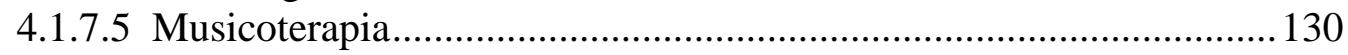

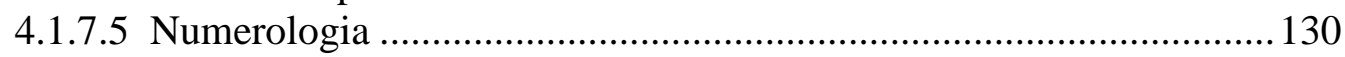

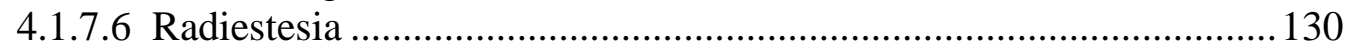

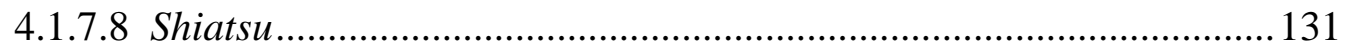

4.1.8 Relação entre a utilização de práticas alternativas e a motivação dos

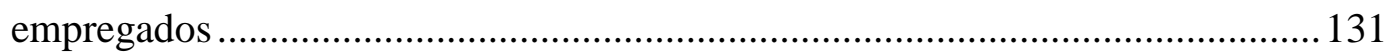

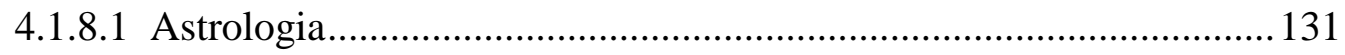

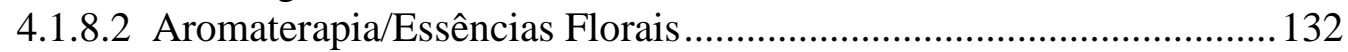

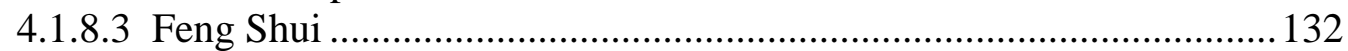

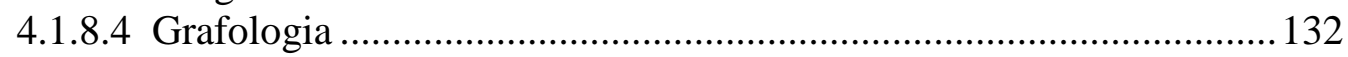

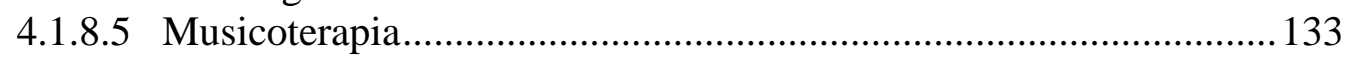

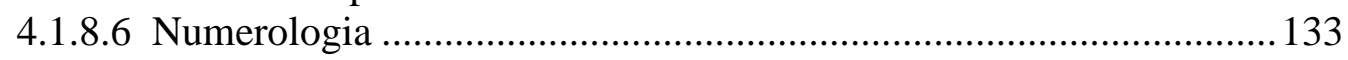

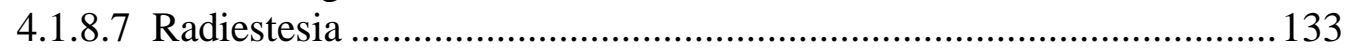

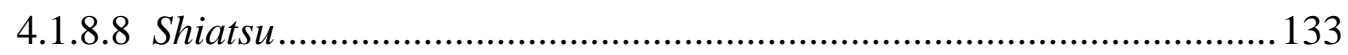


4.1.9 Relação entre a utilização de práticas alternativas e a qualidade de vida no trabalho 134

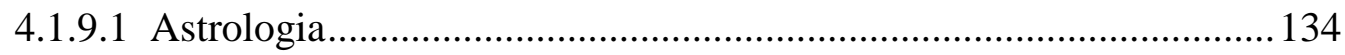

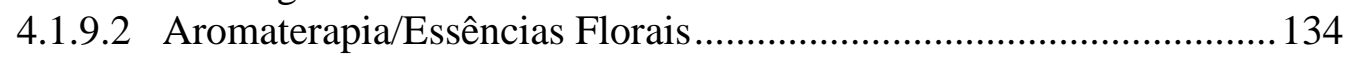

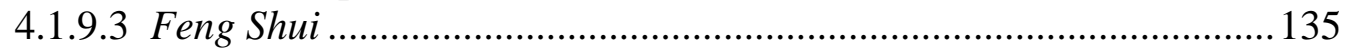

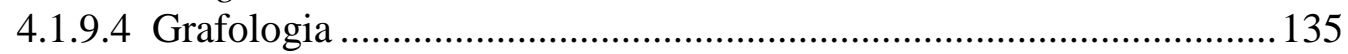

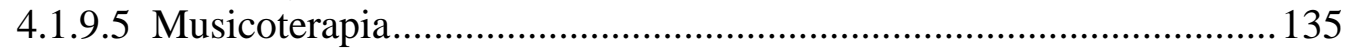

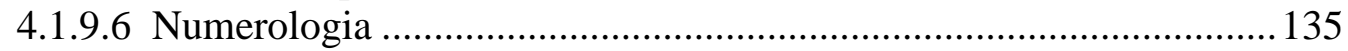

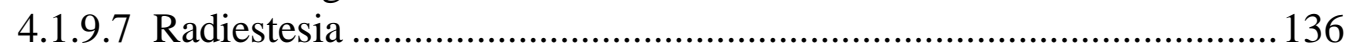

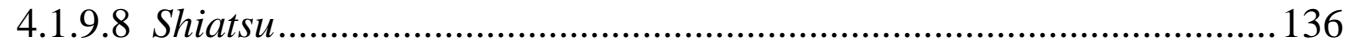

4.1.10 Análise complementar de dados coletados com os especialistas..............136

4.2 As práticas alternativas na visão dos gestores das empresas pesquisadas ........ 136

4.2.1 Perfil dos gestores entrevistados e das práticas utilizadas......................... 137

4.2.2 Descrição dos casos pesquisados......................................................... 141

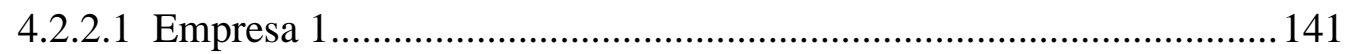

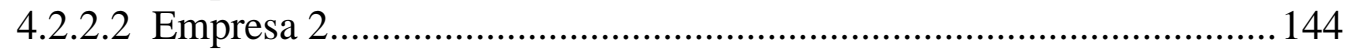

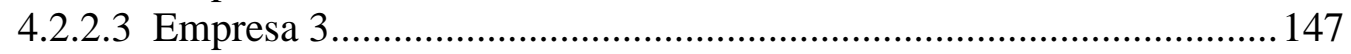

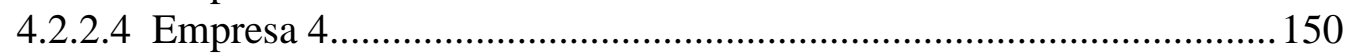

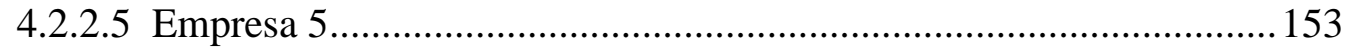

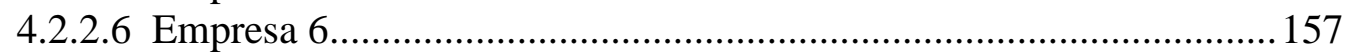

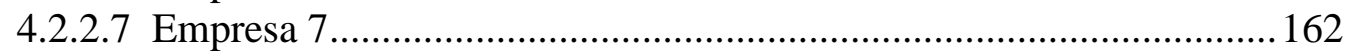

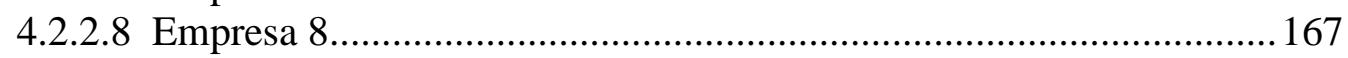

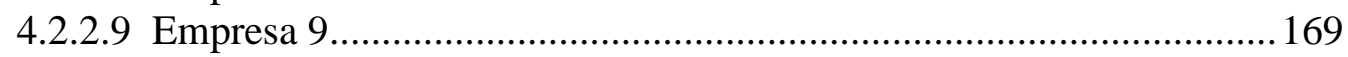

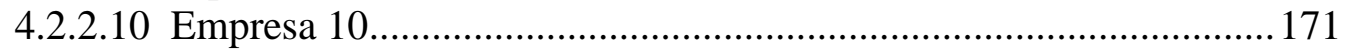

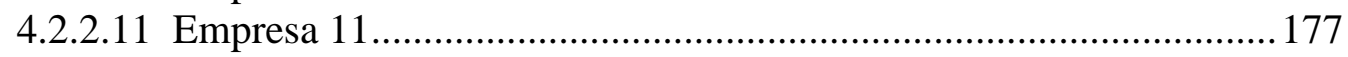

4.2.3 Análise dos dados obtidos nas empresas pesquisadas ............................. 181

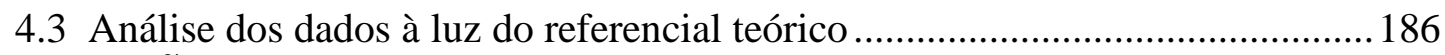

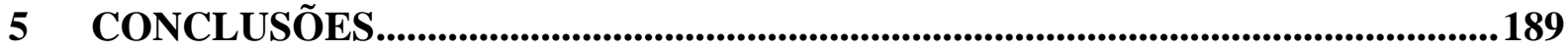

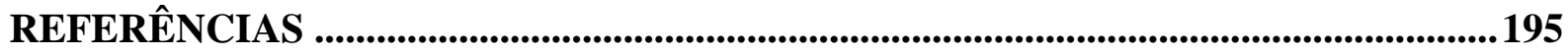




\section{LISTA DE SIGLAS}

ABQV: Associação Brasileira de Qualidade de Vida

ABTD: Associação Brasileira de Treinamento e Desenvolvimento

AERH: Administração Estratégica de Recursos Humanos

APARH: Associação Paulista de Administração de Recursos Humanos

ARH: Administração de Recursos Humanos

IPD: Institute of Personnel Management

ISMA: International Stress Management Association

ISO: International Organization for Standartization

LER: Lesão por Esforços Repetitivos

MCA: Medicina Complementar e Alternativa

OCT: Organização Científica do Trabalho

QVT: Qualidade de Vida no Trabalho

RAUSP: Revista de Administração da Universidade de São Paulo

RH: Recursos Humanos

SINARJ: Sindicatos dos Astrólogos do Rio de Janeiro

SOM: Sistema de Organização Musical

T\&D: Treinamento e Desenvolvimento

UNB: Universidade de Brasília 


\section{LISTA DE QUADROS}

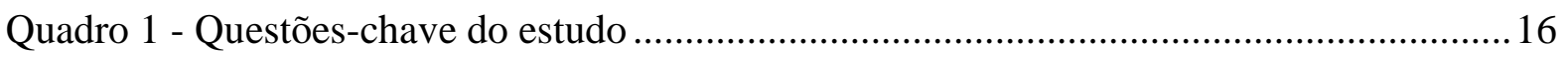

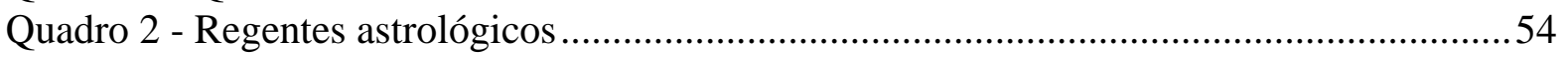

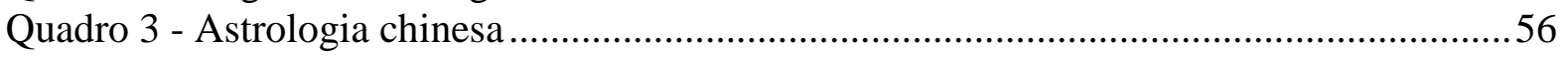

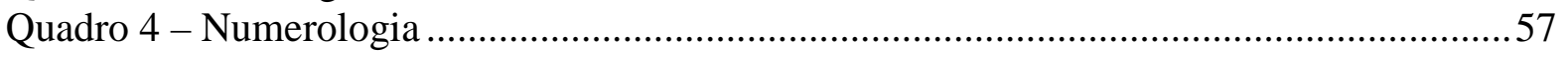

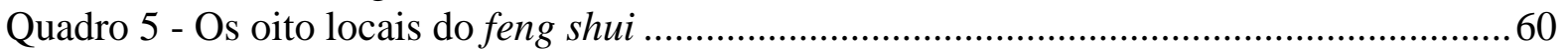

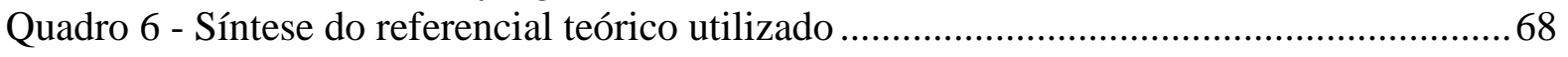

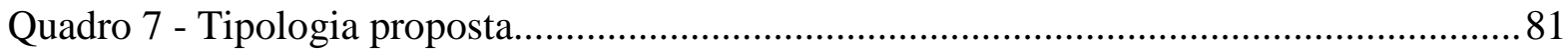

Quadro 8 - Vantagens/desvantagens das práticas alternativas quando comparada às práticas

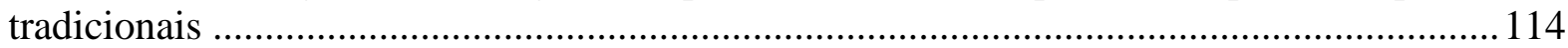




\section{LISTA DE GRÁFICOS}

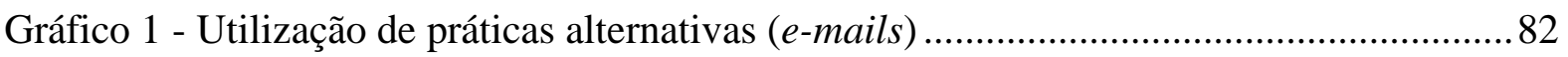

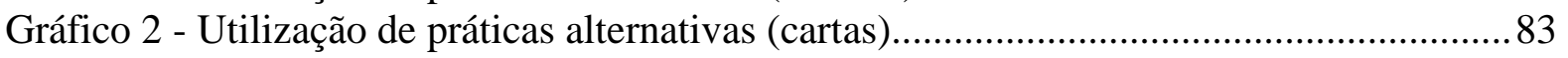

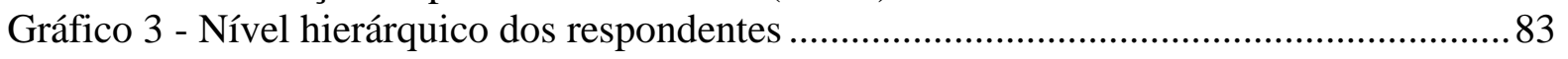

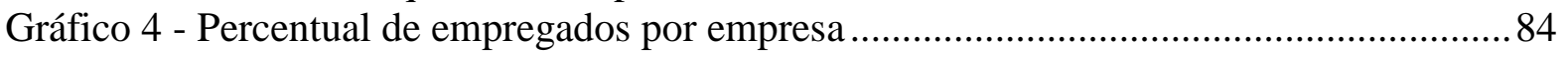

Gráfico 5 - Utilização de práticas alternativas (ConfrariaRH) ............................................... 85

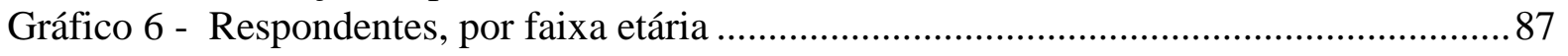

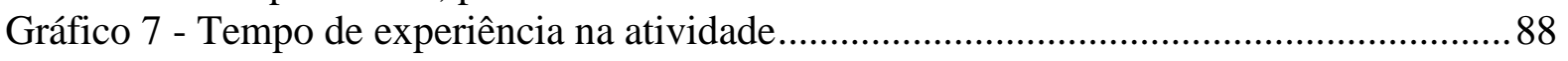

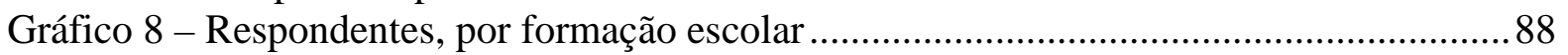

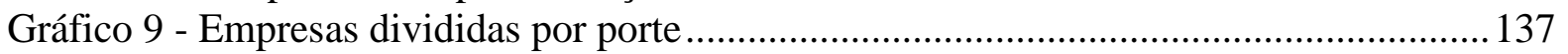

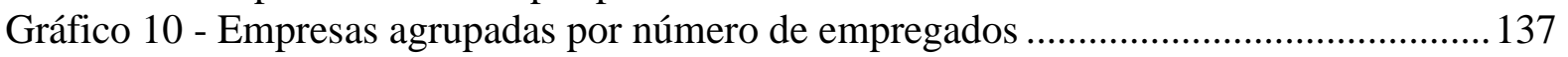

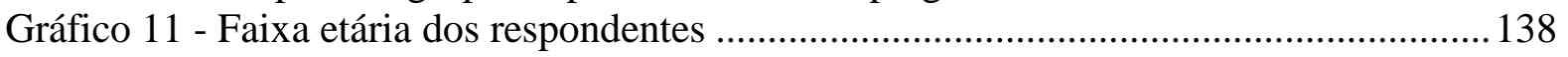

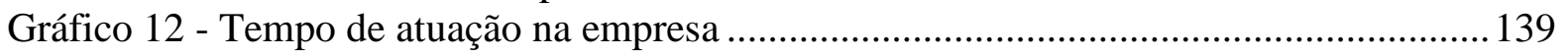

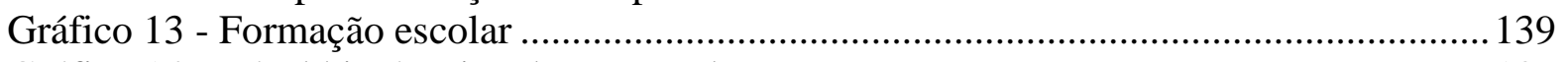

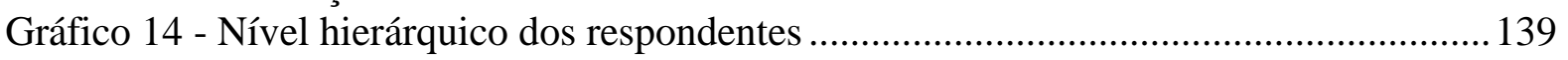




\section{LISTA DE FIGURAS}

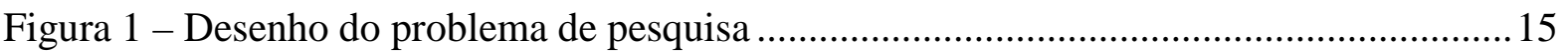

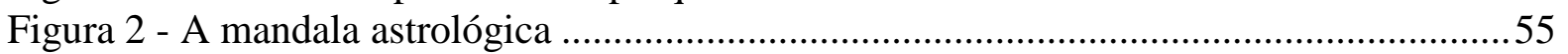

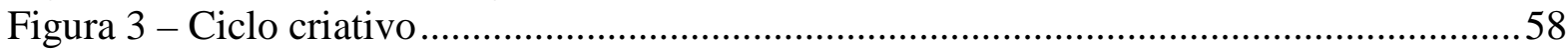

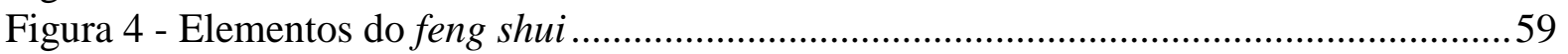

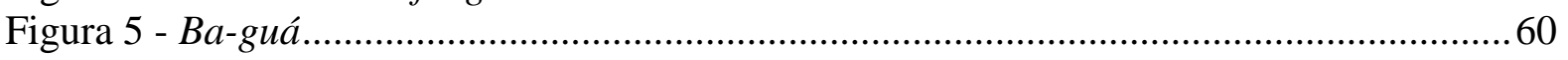

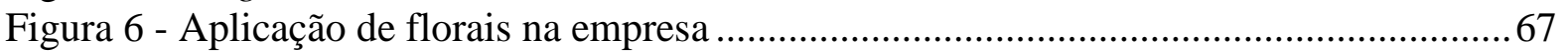

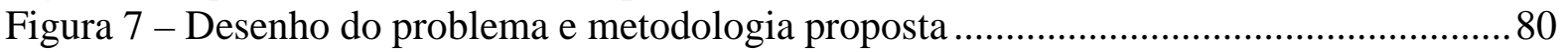




\section{LISTA DE TABELAS}

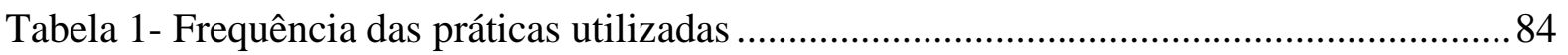

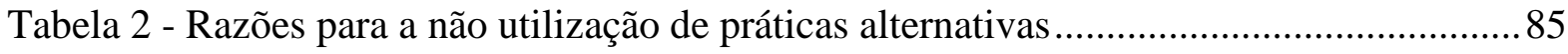

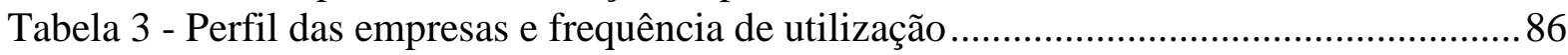

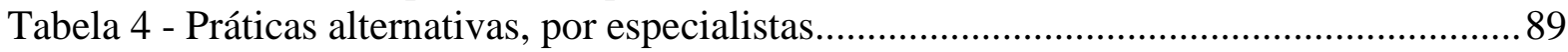

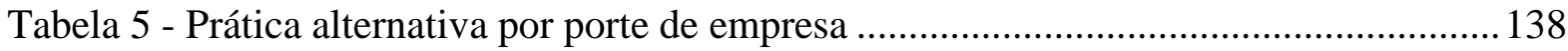

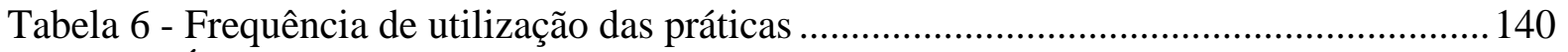

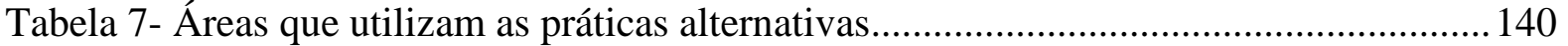




\section{LISTA DE ANEXOS}

ANEXO 1 - E-mails enviados para empresas de grande porte...........................................206

ANEXO 2 - Pesquisa junto aos gerentes da área de Gestão de Pessoas ................................207

ANEXO 3 - Pesquisa junto a especialistas em ferramentas alternativas..............................208

ANEXO 4 - Pesquisa junto a especialistas ................................................................... 210

ANEXO 5 - Pesquisa junto aos dirigentes que atuam na área de gestão de pessoas e

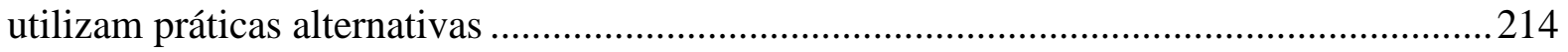

ANEXO 6 - Previsão astrológica entregue semanalmente à empresa e afixada no Mural para consulta de todos os empregados. 


\section{INTRODUÇÃO}

As últimas décadas do século XX foram marcadas pela emergência de abordagens consideradas inovadoras na Administração de Empresas, para aquele momento histórico como, por exemplo, a gestão pela qualidade total, a reengenharia, o downsizing, dentre outros.

A proliferação de temas desta natureza ocorreu porque, na busca incessante por dominar cada vez mais fatias de mercado e se tornarem benchmarking em relação às concorrentes, muitas organizações voltaram sua atenção para o desenvolvimento de novas tecnologias, o lançamento de novos produtos, o investimento no aperfeiçoamento de seu corpo técnico e gerencial, só para citar algumas ações.

Mas não foram apenas alterações dessa natureza que despertaram a atenção dos administradores. Questões de ordem metafísica passaram a fazer parte da rotina de algumas organizações. Segundo Aranha e Martins (1993, p.380) metafísica é a parte da filosofia que estuda "o ser enquanto ser". Segundo as autoras, "é para Aristóteles a ciência primeira, na medida em que fornece a todas as outras o fundamento comum, isto é, o objeto ao qual todas se referem e os princípios dos quais dependem". Chauí (1999, p.229) resume os temas e objetos da metafísica em:

- " o ser como substância e como essência;

- diferença entre essência e acidente;

- origem e estrutura do mundo ou da realidade;

- o infinito e o finito (diferenças e relações);

- o espírito e a matéria (diferenças e relações);

- o espaço e o tempo (diferenças e relações);

- a vida e a morte."

$\mathrm{Na}$ terminologia corrente metafísica refere-se ao que é transcendente, sutil, abstrato e nebuloso, conforme Ferreira (2004, p.1319), Luz (1963, p.356) e Luft (2001, p.455). Neste estudo, a palavra metafísica é utilizada para designar as práticas de gestão que têm como pressuposto a simbologia, a teologia,o conhecimento oriental milenar e práticas correlatas aplicadas à performance organizacional. 
Neste sentido, durante os anos 90, com a expectativa do final do milênio, aliada à expansão da Internet, proliferaram sites divulgando serviços destinados a empresas, utilizando, para isso, ferramentas antes aplicadas de forma mais individual, como é o caso da astrologia, feng shui, grafologia, numerologia, essências florais, além de práticas em saúde como shiatsu, terapia corporal, dentre outras. Consideradas alternativas, tais práticas têm por objetivo apoiar as áreas que cuidam da gestão de pessoas como um todo e, de modo especial, aquelas voltadas à seleção de empregados e à qualidade de vida no trabalho, como é o caso das ações relativas à saúde.

O termo prática alternativa é conceituado por Amorim (1995, p. 1) como "uma denominação genérica para um conjunto bastante heterogêneo de atividades, incluindo desde técnicas adivinhatórias e de descrição de personalidade, até técnicas de medicina alternativa baseadas em pressupostos místicos e religiosos".

Esse fato conduz a indagação sobre os motivos que levam alguns especialistas a ofertarem serviços dessa natureza para empresas, bem como em que medida há receptividade para essas práticas, como afirmam aqueles que delas se utilizam.

Uma primeira possibilidade diz respeito às restrições apresentadas pelas práticas já consagradas no âmbito da gestão de pessoas, em suas respostas aos problemas empresariais. Um exemplo, é a organização do espaço físico de trabalho, voltada para a melhoria da produtividade e a segurança, em detrimento de seu impacto na ambiência organizacional. Situação dessa natureza ocorreu em uma refinaria de petróleo: após um estudo de engenharia, definiu-se por construir uma casa de controle integrado. Ainda que ocorresse uma explosão de grandes proporções, o local não seria afetado.

Quando concluído o projeto e as pessoas começaram a trabalhar naquele espaço, verificou-se que elas apresentaram mudanças de humor, pois era um local com pouca luz, sem janelas ou qualquer quadro ou adereço que o tornasse menos rígido. Apesar da tentativa de se contratar uma empresa de arquitetura, que elaborasse um projeto de harmonização daquele espaço, as melhorias ambientais não foram implantadas, sob a alegação de representarem risco para os empregados, caso ocorresse alguma emergência ${ }^{2}$. Essa é uma visão típica da abordagem

\footnotetext{
${ }^{1}$ Neste estudo, o termo prática alternativa é utilizado com o mesmo sentido de ferramenta alternativa.

${ }^{2} \mathrm{O}$ evento ocorreu no início dos anos 90 e foi vivenciado por esta pesquisadora.
} 
tradicional, na qual questões ambientais só são consideradas enquanto representarem riscos físicos ao trabalhador. Os efeitos psicológicos são ignorados ou relegados a um segundo plano.

Outra situação diz respeito às estratégias de seleção de profissionais, baseadas em competências definidas pela organização, com apoio de testes e entrevistas que, embora extremamente especializadas, podem levar a enganos, uma vez que são relativamente comuns e conhecidas no mercado e podem, dependendo do nível de formação do candidato, ser respondidas de forma a satisfazer as expectativas da organização sem, no entanto, virem a expressar a dimensão real de seu perfil.

A lacuna deixada por essas ferramentas tradicionais instiga a busca de alternativas para suprilas, como é o uso do feng shui, por arquitetos que desenvolvem projetos do layout interno de empresas; o trabalho de consultoria que profissionais oferecem a executivos de empresas, em astrologia e numerologia, e outros divulgados, como os citados a seguir:

- $\quad$ Kuramont (1994, p. 35) relata uma experiência organizacional, na qual utilizou as cartas do tarô, como apoio aos processos de qualidade.

- Boog (1995, p. 185) fez uso de terapia floral individual e de aromas borrifados no ambiente, em seminários realizados dentro de um Programa de Revitalização Organizacional desenvolvido na empresa Usina da Barra, em Barra Bonita, São Paulo, com uma percepção positiva em $95,8 \%$ das pessoas entrevistadas. Trabalho semelhante foi realizado nas empresas Inepar, em Curitiba, Paraná, Otam e Metalúrgica Becker, em Porto Alegre, Rio Grande do Sul.

- A utilização da grafologia como insumo para o rodízio de executivos, que vem sendo conduzida dentro do Grupo Pão de Açúcar, cujo trabalho foi apresentado no $1^{\circ}$ Fórum de Ferramentas Avançadas na Gestão de Pessoas, organizado pela Associação Paulista de Administração de Recursos Humanos (APARH) e realizado em dezembro de 2003.

A aplicação dessas práticas, além de uma mudança nos paradigmas da administração clássica, que tinha como pressuposto separar a mente do corpo, o gerente do operário, é também uma forma diferente de se buscar a melhoria do trabalho, através de uma visão mais holística do 
homem e de suas relações. Tal abordagem, analisada sob a dimensão de ferramentas alternativas, incorpora, à prática empresarial, vivências antes relatadas apenas no âmbito individual e muito voltadas para práticas consideradas místicas, como é o caso da numerologia e da astrologia. Por outro lado, trata-se de uma abordagem cuja proposta é ainda etérea, sem estudos científicos comprovados e, portanto, questionada e criticada no âmbito acadêmico. Pesquisar esse assunto segundo uma perspectiva crítica e científica se revela, portanto, um verdadeiro desafio.

O presente estudo foi concebido porque, embora muitos autores escrevam sobre várias dessas ferramentas alternativas, o objetivo, na maior parte dos casos, tem sido mostrar seu funcionamento prático como o de Webster (1998) e Szanto (1989) sem, contudo, evidenciar os resultados com fatos e dados. Em geral, também as publicações não se caracterizam como artigos científicos. Só para citar um exemplo, em consulta aos artigos publicados pela Revista de Administração da Universidade de São Paulo (RAUSP), não foram encontrados artigos abordando quaisquer dessas ferramentas.

Por outro lado, segundo depoimentos informais de profissionais que prestam serviços utilizando essas práticas, há procura por gestores de empresas. Quando indagados sobre qual o tipo de organização, esses respondem de forma imprecisa, alegando ausência de permissão para citar nomes. Tal fato, aliado à falta de pesquisa sobre o assunto, inviabiliza qualquer afirmação que corrobore ou refute a existência de empresas que utilizem essas ferramentas, bem como a de precisar o tamanho de empresa ou setor de atividade a que pertencem.

Ante a ausência de dados, o percurso escolhido para esta pesquisa foi, inicialmente, voltar-se para empresas brasileiras de grande porte, pois, de modo geral, elas têm uma área relacionada à Gestão de Pessoas. Acreditava-se que empresas de pequeno e médio portes utilizassem pelo menos algum tipo de ferramenta alternativa. As evidências mostraram que a premissa quanto ao porte da empresa estava equivocada, o que levou esta pesquisadora a mudar o escopo do projeto. A direção seguida passou a ser, então, a busca por organizações, independentemente de seu porte, que utilizam ou utilizaram algum tipo de ferramenta alternativa. 


\subsection{Problema de pesquisa}

Para este estudo, foi definido como problema de pesquisa:

Identificar a existência, em empresas, de práticas alternativas na gestão de pessoas e sua relação com a cultura organizacional.

O desenho do problema de pesquisa encontra-se demonstrado na Figura 1.

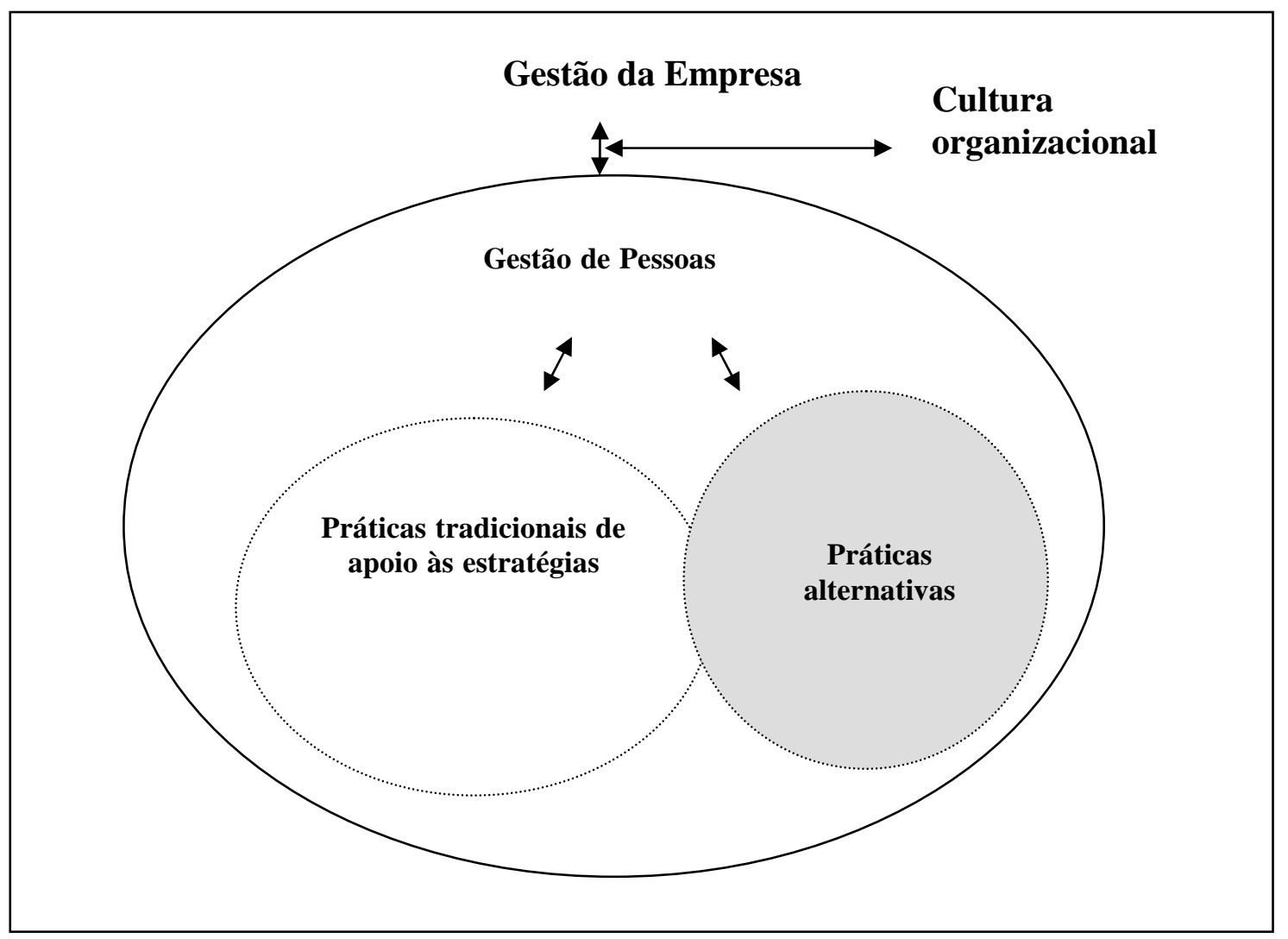

Figura 1 - Desenho do problema de pesquisa

As questões-chave estão contidas no Quadro 1. 
Quadro 1 - Questões-chave do estudo

\begin{tabular}{|l|l|}
\hline \multicolumn{1}{|c|}{ Questões-chave do estudo } & \multicolumn{1}{|c|}{ Comentário } \\
\hline $\begin{array}{l}\text { 1. Empresas que têm uma área voltada para a gestão de } \\
\text { pessoas utilizam algum tipo de ferramenta alternativa como } \\
\text { apoio às práticas tradicionais? }\end{array}$ & $\begin{array}{l}\text { Focar o estudo em qualidade de vida no trabalho, } \\
\text { recrutamento e seleção e gestão organizacional. }\end{array}$ \\
\hline $\begin{array}{l}\text { 2. Qual o porte ou o setor empresarial que mais utiliza essas } \\
\text { práticas? }\end{array}$ & $\begin{array}{l}\text { Observar se o porte da empresa ou o setor em que } \\
\text { se localiza tem alguma relação com a utilização } \\
\text { dessas práticas. }\end{array}$ \\
\hline $\begin{array}{l}\text { 3. Quem são os trabalhadores beneficiados com a utilização } \\
\text { de ferramentas alternativas? }\end{array}$ & $\begin{array}{l}\text { Verificar se existe alguma relação entre } \\
\text { hierarquia e as práticas alternativas. }\end{array}$ \\
\hline $\begin{array}{l}\text { 4. Quais são as práticas mais utilizadas? } \\
\text { 5. Em quais situações as empresas as utilizam? }\end{array}$ & $\begin{array}{l}\text { Identificar quais as práticas são mais encontradas } \\
\text { nas organizações. }\end{array}$ \\
\hline $\begin{array}{l}\text { 6. Como as empresas utilizam essas ferramentas em gestão } \\
\text { de pessoas? }\end{array}$ & Áreas que mais fazem uso dessas práticas \\
\hline 7. Quais motivos levam as empresas a utilizá-las? & Identificar causa ou grupo de causas. \\
\hline 8. Quais os resultados alcançados? & Identificar a existência de formas de medição. \\
\hline
\end{tabular}

\subsection{Objetivo da pesquisa}

Do problema de pesquisa explicitado, estabeleceu-se como objetivo geral do projeto:

Reunir informações que possibilitem identificar e descrever a existência de práticas alternativas na gestão de pessoas das empresas pesquisadas e a relação com a cultura organizacional.

Como objetivos específicos, este estudo se propõe a:

1. Identificar as principais práticas, consideradas alternativas, utilizadas na gestão de pessoas.

2. Descrever o significado e a forma de aplicação dessas práticas nas empresas, nos aspectos de qualidade de vida no trabalho e seleção de pessoal.

3. Levantar as razões que levaram os gestores organizacionais de pessoas a utilizarem tais práticas. 
4. Identificar quais os resultados obtidos a partir da adoção dessas práticas.

5. Identificar possíveis vantagens e desvantagens das práticas alternativas, quando comparadas às práticas consideradas tradicionais em gestão de pessoas, a partir da visão de especialistas no assunto e dos gestores da área.

6. Identificar a relação entre a cultura organizacional e a aceitação de práticas alternativas.

Este estudo, de caráter exploratório, está sendo apresentado da seguinte forma:

1. No capítulo relativo ao Referencial Teórico, discute-se a visão de autores que tratam da dimensão da psique, da sociologia, da holística e da administração, que subsidiaram a análise das práticas alternativas em gestão de pessoas e descrevem-se os principais aspectos de algumas dessas ferramentas segundo a literatura nacional e a internacional.

2. No capítulo relativo à Metodologia, é descrito o caminho que norteou o desenvolvimento da pesquisa.

3. No capítulo que trata da Pesquisa de Campo e Análise dos Dados são descritas e analisadas as informações coletadas de:

a) Especialistas, que prestam serviços em organizações, aplicando práticas alternativas;

b) Gestores de empresas que utilizam ou utilizaram algum tipo de prática alternativa em sua rotina de trabalho.

4. No capítulo relativo às Conclusões e Recomendações, são apontadas as evidências encontradas na pesquisa de campo quanto à utilização de práticas alternativas na gestão empresarial.

5. Nas Referências Bibliográficas consta o material consultado para elaboração deste estudo. 


\section{REFERENCIAL TEÓRICO}

\subsection{Abordagens conceituais utilizadas na pesquisa}

O objeto de estudo proposto nesta pesquisa não contempla um arcabouço teórico estruturado. Por esta razão, optou-se por discutir inicialmente o que não se considera prática alternativa, uma vez que, em gestão de pessoas, existem ferramentas aceitas tanto na comunidade acadêmica, como nas organizações.

$\mathrm{Na}$ continuidade, são descritas algumas experiências recentes que sinalizam para o desenvolvimento de práticas alternativas em outras áreas do conhecimento.

$\mathrm{Na}$ terceira parte, são examinadas as dimensões psíquica, sociológica e holística e sua relação com a teoria das organizações, focando-se aspectos que abrem espaço para a discussão das ferramentas alternativas. Um tópico foi desenvolvido para tratar da dimensão administrativa, sob o ponto de vista da gestão de pessoas de modo global e da qualidade de vida no trabalho, por serem as áreas nas quais a pesquisa foi concentrada.

Em seguida, discute-se o conceito de ferramentas alternativas para esta pesquisa e, por fim, faz-se, de forma resumida, descrição de algumas dessas ferramentas, objeto da investigação na pesquisa de campo, que foram encontradas de forma estruturada em empresas. São elas: astrologia, numerologia, feng shui, grafologia, radiestesia e shiatsu. São ainda descritas, de forma resumida, florais, aromaterapia e musicoterapia, que foram alvo de pesquisa realizada com especialistas.

\subsection{Práticas “tradicionais" nas organizações}

Neste estudo, dá-se o nome de ferramentas "tradicionais" àquelas práticas aceitas academicamente e no cotidiano organizacional, por já terem sido submetidas à investigação científica e seus resultados corroborados. Embora a análise delas não esteja no escopo deste estudo, optou-se por examinar três consideradas significativas: os testes psicológicos, a 
monitoração do clima organizacional e a avaliação de desempenho. Cabe lembrar que não se pretende questionar a validade dessas ferramentas. Busca-se somente verificar se as práticas alternativas estão encontrando espaço nas organizações, compondo com as tradicionais ou, conforme o caso, as substituindo total ou parcialmente.

\subsubsection{Testes psicológicos}

$\mathrm{Na}$ área de gestão de pessoas, algumas ferramentas da psicologia são muito utilizadas, principalmente em recrutamento e seleção. Dentre elas, citam-se os testes psicológicos.

Segundo Limongi-França (2002, p. 69), testes psicológicos são instrumentos-padrão utilizados para estimular determinados comportamentos da pessoa a ser examinada e, baseado na situação de teste, predizer como é o comportamento dela. Trata-se de um processo de medição ou avaliação.

Embora as diferenças entre as pessoas venham sendo medidas há muitos anos, a sistematização de testes de seleção, segundo Carvalho (2000, p. 61), ganhou maior interesse a partir da I Guerra Mundial, em face da necessidade de se selecionar um grande contingente de combatentes para as Forças Armadas. Segundo o autor, testes como o Army Alpha Intelligence Test e o Army Beta Intelligence Test, este último destinado a pessoas analfabetas, foram desenvolvidos nos Estados Unidos e se constituem nos primeiros testes usados na atualidade.

Gil (2001, p. 51) avalia que os testes psicológicos foram amplamente difundidos no Brasil, até meados da década de 70, quando sofreram declínio. Isso ocorreu porque se reconheceu que sua validade é relativa: é eficiente na avaliação de candidatos para tarefas administrativas, mas não oferece bons resultados para os que devem realizar tarefas executivas.

Limongi-França (op.cit.) divide os testes psicológicos em psicométricos, utilizados para medir a aptidão individual, como é o caso de testes de inteligência, e testes de personalidade, destinados a identificar, além de traços da personalidade, aspectos motivacionais, interesses e possíveis distúrbios, como é o caso do teste de Rorschach. 
Os testes psicológicos, como o nome indica, devem ser aplicados somente por psicólogos. Existem ferramentas que, embora tenham como premissa analisar aspectos de personalidade, não são validadas pelo Conselho Federal de Psicologia e, portanto, não podem ser intitulados como "teste psicológico". É o caso, por exemplo, da grafologia.

\subsubsection{Monitoramento do clima organizacional}

Trata-se de um retrato extraído em dado momento, em forma de pesquisa, sobre aspectos da relação funcional pré-definidos pelos gestores de uma organização, a partir da avaliação dos seus empregados. De modo geral, essa avaliação ocorre por meio do preenchimento de um questionário, enviado a uma amostra ou ao conjunto de empregados, em papel ou por meio eletrônico.

Os dados obtidos são, via de regra, relativos a itens que possibilitam medir a satisfação do empregado, como recompensa, reconhecimento, benefícios, liderança, treinamento, saúde, segurança, dentre outros.

Para Gil (op.cit.), o interesse das organizações em utilizar essa ferramenta fundamenta-se na necessidade de identificar e medir as atitudes dos empregados, em relação a programas, políticas e práticas adotados pela empresa; conhecer o ponto de vista dos empregados que possibilite melhorar as relações de trabalho; acompanhar a tendência dessas opiniões a partir de pesquisas desenvolvidas periodicamente; identificar aspectos que possam estar intervindo na satisfação e no moral da força de trabalho; e, finalmente, demonstrar ao grupo de empregados o interesse da empresa em conhecer a opinião deles.

A prática em medir e acompanhar os indicadores de ambiência organizacional ganhou relevância com os programas de qualidade total e certificação da International Organization for Standardization (ISO). A esse processo, acoplaram-se programas de cunho comportamental, coordenados pelas áreas de recursos humanos voltados para o desenvolvimento de equipe e a motivação dos empregados. 


\subsubsection{Avaliação de desempenho}

Conforme Davis (1992, p. 99), avaliação de desempenho é o processo utilizado, pela organização, para verificar a qualidade de atuação de seus empregados. Para Lucena (1995, p. 130), embora nem todas as organizações tenham uma ferramenta sistematizada de avaliação de desempenho, trata-se de uma atividade natural do líder e, freqüentemente, utilizada para justificar as decisões acerca de seus subordinados.

Davis (op.cit.) considera que essa ferramenta é necessária para o desenvolvimento de outros sistemas de gestão de pessoas, quais sejam: alocação de recursos, recompensa de empregados, feedback sobre o trabalhado realizado, manutenção de um relacionamento com o grupo, aconselhamento e desenvolvimento dos empregados e, por fim, atendimento aos regulamentos da organização.

Esse instrumento, em muitas empresas, é dividido em aspecto físico, ou seja, a comparação entre as metas que foram definidas no processo de planejamento e os resultados que foram atingidos, e a avaliação de aspectos comportamentais, pautados em atitudes esperadas do empregado em relação àquelas que ele efetivamente demonstrou.

Como instrumento de medição, a avaliação de desempenho tem sido utilizada como um dos insumos a processos de promoção, reposicionamento salarial, dentre outros.

\subsection{O estudo das práticas nas áreas do conhecimento}

O referencial teórico que trata de ferramentas alternativas é difuso. Este é um tema que se encontra no limiar da ciência e, por essa razão, quase não foi estudado, principalmente em áreas formadas a partir de uma visão funcionalista de mundo, como é a de administração de empresas.

Uma ciência que, todavia, vem mostrando interesse por pesquisar fenômenos inexplicáveis é a medicina. Em artigo publicado na revista CartaCapital (2004, p. 44), discutiu-se o poder da fé sobre a saúde. O texto relata um experimento no qual um grupo, composto por mulheres com problemas de fertilidade, foi submetido ao mesmo tratamento por médicos na 
Coréia. Destas, metade foi separada e suas fotos enviadas para grupos de reza em países distantes, como Estados Unidos, Canadá e Austrália, sem que elas próprias e seus médicos soubessem do fato. Para espanto dos pesquisadores, nesse grupo, duas vezes mais mulheres engravidaram, se comparadas às mulheres do outro grupo.

Segundo Akiyama (2004, p. 5), o aumento na demanda pela Medicina Complementar e Alternativa (MCA), contudo, não partiu dos médicos e, sim, da procura dos pacientes por essa abordagem. Para o pesquisador, os médicos no máximo "passaram a oferecer esta abordagem".

No Brasil, questões dessa natureza também começam a suscitar interesse e estão se tornando objeto de pesquisa. Em reportagem que foi ao ar no dia 25 de junho de 2004, no programa Globo Repórter, um dos temas discutidos foi uma pesquisa desenvolvida pelo Núcleo de Estudos dos Fenômenos Paranormais da Universidade de Brasília (UNB), coordenada pelo professor Paulo César dos Reis Gomes, sobre a validade da previsão astrológica: “de todas as afirmações dos pesquisados que participaram, de 0 a 100, a nota média final foi de 95", ressalta o professor.

Um dos membros da equipe, professor do Departamento de Engenharia Mecânica da UNB, Hiroshi Masuda, coordena, desde outubro de 2003, um curso de astrologia naquela escola. Segundo consta em reportagem da revista Isto É (2004), Masuda criou uma fórmula matemática para explicar as semelhanças psicológicas entre pessoas que nasceram em uma mesma cidade, em horário parecido e no mesmo ano.

A astrologia e as rezas, a exemplo de outras ferramentas alternativas, estão se tornando objetos de pesquisa científica. São utilizadas por segmentos da mesma população que trabalha nas organizações, objeto de estudo da administração de empresas, razão pela qual surgiu a indagação sobre se algumas dessas ferramentas se constituem em práticas empresariais. 


\subsection{A dimensão psíquica e a teoria das organizações}

Este tópico analisa como pesquisadores da área de psicologia avaliam as relações de trabalho e a postura deles em relação a temas como as práticas alternativas. No primeiro item, discute-se a psicodinâmica organizacional a partir da visão de Dejours. No segundo item, busca-se analisar a contribuição de Jung para o estudo das práticas alternativas, uma vez que esse pesquisador é citado por especialistas, como um teórico que influenciou o desenvolvimento de algumas das práticas analisadas.

\subsubsection{Psicodinâmica organizacional}

Entende-se por psicodinâmica organizacional a abordagem que trata da análise institucional sob a ótica do comportamento das pessoas, no âmbito profissional, e sua repercussão nos resultados organizacionais, sobretudo naqueles relativos à ambiência.

Para este tópico, optou-se pela análise de Christophe Dejours (1988), um estudioso da psicopatologia do trabalho. Na visão desse autor, a gestão empresarial, quando voltada para a maximização dos lucros, sem considerar de forma prioritária as pessoas que contribuem para esses resultados, causa um profundo sofrimento no trabalhador e é base de muitas das doenças, hoje recorrentes, nas organizações.

Dejours é um crítico de Frederick Winslow Taylor e da Organização Científica do Trabalho (OCT). Não há como negar que as contribuições de Taylor para a organização do trabalho, no final do século XIX e início do século XX, foram essenciais para o desenvolvimento do estudo da administração, em uma perspectiva de produção de conhecimentos. Conforme Maximiano (2002, p. 151), Taylor preocupou-se com a organização dos processos de fabricação e em como tornar mais eficiente a produção dos operários, utilizando, para isso, estudos relacionados ao tempo e aos movimentos no processo de trabalho. Em seus estudos, Taylor propunha concentrar as atividades intelectuais em uma área de planejamento e deixar a atividade operacional para empregados e supervisores. 
A crítica de Dejours (1988, p. 39) em relação ao projeto da OCT é realizada do ponto de vista psicopatológico ${ }^{3}$. O autor aponta as consequiências dessa padronização:

\begin{abstract}
"O homem no trabalho, artesão, desapareceu para dar a luz a um aborto: um corpo intrumentalizado-operário de massa - despossuído de seu equipamento intelectual e de seu aparelho mental. Além do mais, cada operário é isolado dos outros. As vezes é até pior, pois o sistema pode colocá-lo em oposição aos outros".
\end{abstract}

Embora o modo de produção proposto por Taylor tenha sido submetido a críticas e superação no decorrer do século XX, seus reflexos podem ser observados em várias áreas de atuação da administração como, por exemplo, na padronização do trabalho pregada através da instituição do procedimento ISO 9000.

Um exemplo que segue a mesma trilha de padronização, racionalização e individualismo é a organização dos escritórios em baias ${ }^{4}$, nas quais os trabalhadores são posicionados de frente para uma parede ou divisória tendo para seu uso apenas os equipamentos exclusivamente relacionados ao trabalho. Em grande parte, ficam de costas ou de lado para os demais colegas de trabalho, para concentrar-se apenas em sua atividade de labor. Situações como estas, que demonstram a preocupação fundamental voltada para a organização do espaço e das pessoas objetivando o aumento da produtividade e do lucro, podem ser resumidas nesta frase de Dejours (op.cit., p. 39): "tal é o paradoxo do sistema que dilui as diferenças, cria o anonimato e o intercâmbio enquanto individualiza os homens frente ao sofrimento".

Embora o estudo do autor critique a proposta de padronização de processos e o trabalho repetitivo do operário, o mesmo pode ser feito para outros processos de padronização laboral porque, também, não consideram, via de regra, o equilíbrio psicológico do trabalhador e o seu local de trabalho.

Dejours (op.cit.) considera que o sofrimento do trabalhador aumenta quanto mais rígida for a organização do trabalho e mais acentuada a sua divisão. Como conseqüência, torna-se menor o conteúdo significativo de sua atividade e as possibilidades de alterá-la.

\footnotetext{
${ }^{3}$ Segundo Dejours (op.cit., p. 43), a psicopatologia do trabalho estuda "o que acontece com a vida psíquica do trabalhador desprovido de sua atividade intelectual pela organização científica do trabalho".

${ }^{4}$ Segundo Luft (2001, p. 101) baias são "compartimentos de cavalariças".
} 
Discute ainda a relação entre o conteúdo ergonômico do trabalho e a estrutura da personalidade. Para ele, essa relação deve considerar três componentes principais, a saber: as exigências de ordem física e psicomotora, as exigências de ordem psico-sensorial e, finalmente, as de ordem intelectual.

Ele conclui que a insatisfação para com o trabalho está relacionada não apenas ao conteúdo significativo e simbólico deste, mas também à sua carga, que ele denomina de conteúdo ergonômico da tarefa. Isso significa que a carga de trabalho do empregado precisa estar em consonância com sua estrutura de personalidade, uma vez que uma mesma tarefa pode ter um conteúdo altamente desafiador e motivador para uma pessoa e se revelar desestimulante para outra.

Para Dejours (1994, p. 25), o trabalho permite reduzir ou ampliar a carga psíquica do trabalhador, tornando-se fatigante ou equilibrante. O autor ilustra essas duas dimensões com um exemplo, no primeiro caso, de mulheres que trabalham como datilógrafas ${ }^{5}$ em escritório no qual, em alguns períodos, verifica-se a redução de trabalho. Mesmo assim, elas precisam cumprir a jornada completa de trabalho. Nos momentos em que o gerente se aproxima, elas não podem estar conversando, lendo ou tricotando. Ao contrário, precisam fazer de conta que estão em atividade. Essa postura conduz a uma carga psíquica crescente, seguida de uma fadiga intensa. Em outra situação, ele cita o que denomina de trabalho equilibrante, ao mencionar os pilotos de caça. Embora o trabalho os exponha a riscos de forma permanente e a desafios intensos, a seleção de pessoas consideradas adequadas para tais atividades, acompanhadas de formação profissional rigorosa, faz com que estes não acusem algum tipo de fadiga.

Ao abordar o tema psicopatologia do trabalho, Dejours e Abdoucheli (1994, p. 39), analisa as questões do desejo e da motivação no trabalho. Para tanto, coloca em debate uma questão que considera fundamental: "No trabalho contemporâneo, qual é o lugar do Desejo, e qual é o lugar do Sujeito?”. Para ele, quanto mais o indivíduo sobe na hierarquia da organização, tanto mais há lugar para o desejo e para o sujeito. Na base da hierarquia, pelo contrário, ocorre, em geral, a repressão do desejo e a tentativa por vezes infeliz de sublimação.

\footnotetext{
${ }^{5}$ A máquina de escrever foi substituída pelo microcomputador. Contudo, a situação descrita não se alterou.
} 
No bojo dessa discussão, o autor relaciona motivação a desejo, ao mostrar que o trabalhador, em troca de salário ou prêmio, reprime o desejo e se anula como sujeito, concluindo que a motivação se encontra aí em oposição ao desejo. Mais que isso, Dejours e Abdoucheli (op.cit.) retoma a discussão da proposta da OCT e indaga sobre o que um modo de trabalho padronizado e generalizado ocasionaria para os trabalhadores no que se refere à economia de seu desejo. A resposta que encontra é o sofrimento, alienação e o risco de uma descompensação psíquica ou da somatização desse sofrimento no corpo físico e conclui que a organização do trabalho é que determina as relações entre desejo e motivação. A análise deste autor remete a uma indagação: a utilização de práticas alternativas contribui de alguma forma, para que o trabalhador, na base da pirâmide tenha lugar também para o desejo?

\subsubsection{A psicologia analítica de Jung}

Carl Jung foi um psiquiatra que, ao longo da vida, se preocupou fundamentalmente em compreender o "segredo da personalidade" (Casado, p. 1998), não tratando, portanto, de questões relacionadas à administração de empresas.

Segundo Morgan (1996, p. 229), enquanto Freud enfatizou em seus estudos as exigências que o corpo, por ser portador da psique humana, impunha ao inconsciente, Jung tratou a psique como parte de uma realidade universal e transcendental, ou seja, de um "inconsciente coletivo", que vai além do tempo e do espaço; visão que foi criticada por muitos, uma vez que, para estes, o autor se aproximava do ocultismo. Para o autor, Jung, na verdade, preocupava-se em compreender as questões da religiosidade no ser humano, partindo de seus próprios questionamentos internos.

Nesse sentido, tais estudos foram relevantes para o desenvolvimento de algumas ferramentas alternativas, razão pela qual a importância em citá-lo neste estudo. Arroyo (1975, p. 8) destaca em seu estudo que Jung reconhecia a importância da astrologia como a soma do conhecimento psicológico da antigüidade.

Para Hall (1990, p. 106), foi o grande interesse de Jung pelo ocultismo, misticismo e religião que, aparentemente, o afastou da categoria de psicólogo. As críticas que recebia 
irritavam o psiquiatra que justificava o interesse por "ciências ocultas" como a astrologia, porque forneciam evidências para sua teoria e não porque ele as aceitasse.

Jung (1988) ocupou-se em tentar explicar situações que ocorriam sob a forma de premonição. Para tanto, desenvolveu a teoria da sincronicidade. Esse fenômeno, para o autor (op.cit., p. 25), é constituído de dois fatores:

"1. Uma imagem inconsciente alcança a consciência de maneira direta (literalmente) ou indireta (simbolizada ou sugerida) sob a forma de sonho, associação ou premonição.

2. Uma situação objetiva coincide com este conteúdo".

O termo "sincronicidade" é diferente de "sincronismo", ainda segundo Jung (1988, p. 19). O primeiro refere-se a dois ou vários acontecimentos que aparecem simultaneamente, no tempo e, embora tenham ligação por sua significação ou sentido similar, não possuem alguma relação causal. Já sincronismo refere-se ao aparecimento de dois fenômenos, de forma simultânea.

Para conceber o princípio sincronístico, Jung (op.cit.) aprofunda sua analisa no I Ching ${ }^{6}$, na geomancia e na astrologia. Cita ainda a grafologia, mas ressalta que esta goza de amplo reconhecimento.

Em relação à astrologia, o autor recorre à análise estatística, para analisar a influência dessa prática no mapa de pessoas casadas e não-casadas, demonstrando incômodo com essa questão pois relata, no início de suas conclusões, que não há justificativa para se incluir a astrologia como um método mântico, estando ela em vias de se tornar uma ciência (op.cit., p. 91) Contudo, os resultados de seu estudo mostram que, com raras exceções, as afirmações feitas por astrólogos tem "bases muito frágeis" (op.cit., p. 49) pois os dados que analisou mostram que as probabilidades de ocorrência de casamentos não se confirmam estatisticamente. Com esses dados, Jung (op.cit., p. 93) volta atrás e conclui: "embora eu tenha sido levado a fazer reparos quanto ao caráter mântico da astrologia, agora sou obrigado a reconhecer que ela tem este caráter, tendo em vista os resultados a que chegou meu experimento astrológico".

\footnotetext{
${ }^{6}$ Jung (1988, p. 28) define como um método destinado a "apreender uma situação de globalidade e assim colocar o problema dos detalhes no grande quadro das inter-relações do Yang e do Yin".
} 
Para Morgan (op.cit., p. 230) a produção teórica de Jung o aproxima de Einstein e da física moderna, uma vez que tanto a energia física como a energia psíquica estavam propensas à transformação, por meio de atividades conscientes e inconscientes. Nesta linha de raciocínio, Capra (1983, p. 230), ao traçar um paralelo entre a física moderna e o misticismo oriental, refere-se à noção de um estado de "interligação quântica". Para ele, os físicos "passaram a reconhecer que o universo pode, de fato, constituir-se de interligações que se dão por vias muito mais sutis do que se tinha pensado até então", o que, para ele, reforça as similaridades não somente entre os físicos e os místicos, mas, também, na semelhança de análise da física subatômica e a psicologia junguiana.

Os estudos de Jung sobre a psique humana compõem-se de vários sistemas que, embora funcionem isoladamente, atuam uns sobre os outros. Neste estudo, procura-se ater a alguns pontos, quais sejam, o inconsciente coletivo composto por estruturas que são chamadas de arquétipos (dentre eles a sombra, a anima e o animus e o self) e a individuação.

\subsubsection{Inconsciente coletivo}

O inconsciente coletivo, segundo Hall (1990, p. 36), é uma das partes mais controvertidas do estudo de Jung. Trata-se de um conjunto de traços de memória do passado ancestral do homem, incluindo os ancestrais pré-humanos e animais, que estão armazenados de forma oculta em sua memória.

A relação entre o inconsciente coletivo e o indivíduo, é mediada por arquétipos que, para Jung apud Hamaker-Zondag (1988, p. 11) é definida como:

\footnotetext{
“[...] um elemento formal, em si mesmo, vazio, nada mais do que uma facultas praeformandi (faculdade de pré-formar), uma possibilidade a priori da forma na qual a idéia é representada. Não são nossas idéias questões herdadas mas somente suas formas, que, neste caso, são correspondentes exatos dos instintos também formalmente determinados. Nem os arquétipos nem os instintos se tornam presentes a não ser que se manifestem de forma concreta".
}

Dentre os arquétipos, Jung destaca dois que estão ligados à personalidade e ao inconsciente coletivo, atuando como ligação entre o consciente e o inconsciente. São eles o anima (características femininas no homem) e o animus (características masculinas na mulher). Motta (2000, p. 90), analisando a obra do autor, considera que o resultado final desse processo é a formação de uma pessoa com personalidade integrada, plenamente responsável 
e desenvolvida, o yang e o yin, que os taoístas chamam de masculino e o feminino equilibrados.

O arquétipo que representa o ponto central da personalidade é denominado de Self: É aquele em torno do qual estão girando os demais sistemas. Segundo Hall (1990, p. 45) o self é o objetivo central da vida do homem, aquele que todos procuram, mas poucos conseguem e, de maneira geral, somente na idade madura. São expressões desse arquétipo figuras eminentes, grande parte delas ligada à religião, como Buda e Cristo.

Outro arquétipo é o da "sombra", que são os impulsos (instinto animal) e desejos que não são reconhecidos e desejados pela pessoa, embora estejam presentes sob a forma de face oculta da personalidade. A sombra, para Jung (1988a, p. 8), representa o inconsciente pessoal e por essa razão chega à consciência mais facilmente do que o animus e a anima, que estão muito distantes. Refere que existe certa facilidade para que a pessoa tome consciência de sua sombra, sendo possível a ela reconhecer aspectos seus que são maus. Contudo, a experiência do contato com a parte em que se é absolutamente mau, para o autor é, a um só tempo, rara e perturbadora.

\subsubsection{Individuação}

A análise da dimensão pessoa toma grande parte da vida de Jung (2003, p. 49), ao procurar compreender a individuação que, para ele, acontece quando a pessoa se torna um ser único, porque passa a compreender sua singularidade, tornando-se "si-mesmo". Casado (op.cit.) esclarece que a individuação é o processo através do qual o desenvolvimento e a diferenciação dos sistemas da personalidade atingem o seu grau mais intenso: nesse estágio a psique torna-se saudável e integrada. É um processo no qual, através do autoconhecimento, o indivíduo reconhece a existência desse lado "sombra" de sua personalidade e passa a lidar com ele de forma unificada. Quando isso não ocorre, o indivíduo tende a projetar essa contradição para o mundo externo. 


\subsubsection{O inconsciente coletivo e a individuação no ambiente empresarial}

É possível traçar uma analogia entre a teoria desenvolvida por Jung e o ambiente empresarial. Os administradores, durante longo período de existência da empresa, convivem com o que French (1973) apud Maximiano (2000, p. 105) chama de iceberg organizacional, no qual, a parte visível constitui-se dos objetivos, tecnologias, recursos e estrutura e a parte invisível dos elementos informais, ocultos, como sentimentos, atitudes, conflitos, dentre outros. Assim como o iceberg, a empresa tem um lado submerso, mas presente, um lado "sombra", na linguagem junguiana, embora busque constantemente fazer com que este lado seja extinto para que a organização se torne saudável e integrada.

Com base no conceito junguiano, Ziemer (1996, p. 120) analisa o que denomina de "sombra das organizações". Para ele:

- $\quad$ C conceito de individuação é muito importante porque uma empresa é composta de pessoas, que apresentam uma identidade mais ampla e profunda do que a soma das pessoas que a compõem, e representa a consciência coletiva a esta organização.

- A sombra organizacional é formada pelo conjunto de características que não são compatíveis com a imagem e a identidade desejadas pela organização, como comportamentos, atitudes, valores, crenças e normas.

- $\quad$ O esforço que tanto a pessoa quanto a organização fazem para afastar ou eliminar esta sombra, tem um efeito psíquico inverso e retorna com a mesma intensidade, tornando-se uma ameaça para ambos, prejudicando o clima organizacional e tendo como efeitos o aumento da rotatividade e do absenteísmo, a redução na lucratividade, dentre outros.

Conclui Ziemer (op.cit., p. 120) que "quanto maior o nível de inconsciência da empresa em relação a seus aspectos rejeitados, maior a distância entre o discurso e a prática, entre aquilo que se deseja e aquilo que se realiza".

Por outro lado, para Morgan (op.cit.), da mesma forma que o inconsciente procura manter uma unidade com o ego, também a face invisível da organização deseja ser reconhecida, valorizada. Segundo o autor (op.cit., p. 232), os seguidores de Jung nas organizações são 
unânimes em afirmar que é possível criar nas empresas "novas fontes de energia e criatividade", capazes de torná-las "mais humanas, vibrantes, moralmente preocupadas e responsáveis do que o são até o presente”. Indaga se não serão espaços como esses que levam empresas a buscarem apoio, dentre eles, em ferramentas alternativas.

Ao tratar desses temas, Jung contribui para colocar luz sobre a forma como as organizações, por meio de seus dirigentes, tomam decisões na gestão de seus trabalhadores.

\subsubsection{A psique e o alternativo}

Dejours, na análise da psicodinâmica organizacional, e Jung com seus estudos sobre a sincronicidade, o inconsciente coletivo, os arquétipos e a individuação trazem à tona a existência de outras perspectivas que devem ser pontuadas, no que concerne à gestão de pessoas nas empresas, que podem abrir espaço para a utilização de ferramentas alternativas.

Dejours (op.cit.) critica a administração tradicional no que diz respeito ao fato de privilegiar a padronização do trabalho em detrimento do equilíbrio psíquico do trabalho; os resultados em detrimento do desejo e da motivação.

Morgan (op.cit, p. :231), analisando Jung, lembra a necessidade de a organização considerar, na gestão de pessoas, a existência de um lado invisível, ou seja, a sua própria "sombra", pois é ali, nas palavras do autor, que se encontram "todos os opostos reprimidos da racionalidade, que lutam para emergir e mudar a natureza da racionalidade que está sendo praticada”. Os estudos de Jung sobre astrologia e I ching denotam que as preocupações do autor, focados nos aspectos ocultos da personalidade, embora não fossem direcionados para as organizações, buscam caminhar para além do concreto, em direção até mesmo ao alternativo.

\subsection{A dimensão sociológica, o alternativo e a teoria das organizações}

Este tópico discute a cultura organizacional como um aspecto que facilita ou dificulta a adoção de práticas alternativas nas organizações. Neste sentido, três considerações são relevantes: pontuar distinções acerca do conceito de cultura sob o ângulo da antropologia e 
da sociologia; compreender aspectos da diversidade cultural; e, a seguir, definir o que se entende por cultura organizacional.

\subsubsection{Cultura organizacional}

O conceito de cultura contempla várias definições, tanto antropológicas como sociológicas. Motta (1997, p. 16) refere que a cultura implica adaptação, a qual, se positiva, leva à evolução na direção proposta e, se negativa, leva à correção de rumos. Um outra forma de defini-la considera que a cultura está presente no inconsciente humano e se apresenta através de símbolos. Outra visão, ainda, centra-se nas formas de cognição de distintas comunidades que, da mesma maneira que os indivíduos, optam por determinadas formas de pesquisar, perceber e apreender a realidade.

Num nível antropológico, o autor chama a atenção para o fato de que cultura é uma linguagem, um código que propicia aos grupos e nações um referencial, e possibilita aos seus membros atribuir um sentido para o mundo no qual vivem e para suas próprias ações. A cultura, analisada sob esse ângulo, tem como característica algum nível de continuidade, o que não significa evolução.

O autor (op.cit) enfatiza a existência de uma infra-estrutura inconsciente universal, que permanece em meio aos processos evolutivos. Nesse sentido, ressalta que um dos fatores mais importantes e, quiçá, o mais importante a ser analisado quando se deseja diferenciar a cultura da organização de outra, são os traços das culturas nacionais (ethnomanagement). A organização traz, de algum modo, costumes, crenças, valores e artefatos da cultura nacional. Motta (op.cit., p. 19) conclui que "não há como, portanto, estudar a cultura das empresas que operam em uma sociedade, sem estudar a cultura - ou as culturas - dessa sociedade".

Em relação ao presente estudo, o fato de o Brasil ter uma cultura heterogênea, algumas inclusive tendendo a aceitar aspectos "ocultos", pode ser um facilitador para a discussão de práticas alternativas nas organizações.

Durham (1984, p. 77), por sua vez, discute o conceito de cultura, à luz do marxismo sociológico, mostrando que tal conceito foi construído para responder a problemas 
específicos da investigação antropológica e que, em função disso, apresenta lacunas, quando vistas sob o ângulo da sociologia. A autora observa que analisar padrões culturais não implica estabelecer uma relação entre falso e verdadeiro, uma vez que a existência de regras explícitas ou explicações míticas em um grupo não se constituem em distorções da realidade demonstradas pela ciência e sim na sua produção.

Um segundo aspecto refere-se à inexistência da discussão em antropologia, sobre a oposição entre ciência e ideologia, uma vez que não se contestou a exterioridade do observador; pelo contrário, desenvolveram-se técnicas de pesquisa que objetivaram diminuir os impactos dessa exterioridade e deslocou-se a discussão para o aspecto do relativismo cultural, através da elaboração de categorias de análise que procurassem superar essa distorção.

Finalmente, observa-se a inexistência de relação entre as representações (falso ou verdadeiro) e o poder, uma vez que padrões culturais não são concebidos como instrumentos de dominação, a não ser de forma genérica. O questionamento central de Durham (op.cit.) reside no fato de que, embora seja importante preservar o conceito de cultura como instrumento metodológico para estudo da sociedade, este não incorpora os aspectos políticos que lhe são inerentes e possibilita a emergência de explicações mecanicistas de cunho economicista.

Em que pese esta discussão transcender o objeto deste estudo, foi nele incluído porque, do ponto de vista micro, as organizações, como integrantes da sociedade, reproduzem as relações sociais. Portanto, tendem a incorporar valores dominantes e reproduzi-los internamente, podendo residir, nesse ponto, restrições ou facilidades no tocante a práticas alternativas.

\subsubsection{Diversidade e cultura organizacional}

No bojo da análise da cultura, ressalte-se também a importância conferida por Fleury (2000, p. 22) à diversidade cultural que, para ela, refere-se a um mix de pessoas com diferentes identidades que estão interagindo em um mesmo sistema social. Na análise sociológica, esse ponto tende a caminhar para as formas de dominação de grupos minoritários em termos de poder, seja por motivos étnicos, religiosos, de sexo, dentre outros. Nesse sentido, sinaliza 
que há distintos aspectos a serem considerados na análise da diversidade cultural, dentre eles: sexo, idade, grau de instrução, grupo étnico, religião, origem, raça e língua.

Já Thomas (1996) apud Fleury (op.cit.) sugere que a gestão da diversidade na organização deva contemplar a adoção de um enfoque holístico, de tal forma que possibilite o desenvolvimento das pessoas que nela trabalham. Aceitar a diversidade cultural delas implica aceitar que os modelos produzidos podem ou não ser iguais aos padrões tradicionais. Nas palavras de Fleury (op.cit., p. 23) “o conceito de diversidade está relacionado ao respeito à individualidade dos empregados e ao reconhecimento desta; gerenciar a diversidade implica o desenvolvimento de competências necessárias ao crescimento e sucesso do negócio".

Se, por um lado, a análise de Durham adverte para a tendência de perpetuar aspectos de hegemonia do poder no nível macro (e, por extensão, também em nível micro), o respeito e a aceitação da diversidade podem ser facilitadores para a utilização de ferramentas alternativas nas organizações.

Tendo claros os aspectos relativos à cultura e, a partir dela, a perspectiva de aceitação ou não da diversidade cultural pela organização, cabe, finalmente, conceituar o que se entende por cultura organizacional. Nesse sentido, em que pese a importante contribuição de Fleury (1995, p.24) ao retomar e aperfeiçoar a definição proposta por $\operatorname{Schein}^{7}$ (1992, p. 12), para a cultura organizacional, para os objetivos desta pesquisa, optou-se pela definição por ele proposta :

\footnotetext{
"A cultura é formada pelo conjunto de pressupostos ${ }^{8}$ básicos que um grupo inventou, descobriu, ou desenvolveu, ao aprender a lidar com os problemas de adaptação externa e integração interna e que funcionaram bem o suficiente para serem considerados válidos e ensinados a novos membros como a forma correta de perceber, pensar e sentir com relação a esses problemas" .
}

Schein $(1984$, p. 3$)$ destrincha o conceito que formulou conforme segue:

- Conjunto de pressupostos básicos são os valores finais, que o grupo considera inquestionáveis, por estarem no nível do inconsciente. O autor define três níveis de cultura:

\footnotetext{
7 "A pattern of shared basic assumptions that the group learned as is solived its problems of external adaptation and internal integration, that has worked well enough to be considered valid and, therefore, to be taught to new members as the correct way to perceive, think, and feel in relation to those problems".

${ }^{8}$ Ou seja, premissas básicas.
} 
no primeiro patamar, estão os artefatos e as criações, as tecnologias, a arte e os padrões de comportamento visíveis e audíveis, facilmente observáveis, mas nem sempre compreensíveis para um elemento externo. No segundo patamar, são encontrados os valores esposados. Quando estes estão sujeitos a debate, questionamentos, o autor acredita que devam ser, de fato, denominados de valores, pois têm maior nível de conscientização pelo grupo. No terceiro e último patamar, estão as premissas ou pressupostos básicos; são assim considerados quando, ao ser indagado sobre o tema, o indivíduo recusa-se a discuti-las por considerá-las óbvias, como ocorre, por exemplo, com o pressuposto da escola que deve educar ou com a empresa que deve ser lucrativa. Um conjunto de premissas interrelacionadas que formam um padrão coerente é denominado, por Schein, de paradigma cultural. A conclusão do autor é que analisar apenas os valores de uma organização conduz apenas a manifestações da cultura, sem, contudo, atingir a essência cultural.

- Um grupo é um conjunto de pessoas (quanto mais homogêneas e estáveis mais forte o vínculo), juntas há um tempo tal que lhes foi possível compartilhar problemas (duração e intensidade significativas), resolver esses problemas e verificar a solução deles, e que admitiram novos membros e transmitiram a eles as soluções. A cultura será tanto mais forte e valorizada na medida em que essas experiências forem mais compartilhadas no grupo. É possível a cultura ser perpetuada, por exemplo, pelos dirigentes, desde que estáveis, como ocorre entre os militares. Para decifrar a cultura de uma organização há que se identificar onde estão as unidades sociais estáveis, que culturas essas unidades desenvolveram e como se misturam para compor um todo. A leitura da cultura organizacional será homogênea ou heterogênea, de acordo com as semelhanças ou diferenças desses subgrupos.

- As soluções são inventadas, descobertas ou desenvolvidas a partir de um processo de aprendizagem que envolve dois tipos de situação: 1) aquelas positivas, que produzem reforço positivo ou negativo quanto àquela solução funcionar ou não; 2) aquelas que evitam ansiedade e produzem um efeito positivo ou negativo quanto aos seus resultados. Quando a cultura organizacional possui os dois tipos de situação, é importante identificar cada uma delas, caso se deseje modificar uma ou outra. Schein (op.cit.) ressalta que os elementos culturais do segundo tipo são mais estáveis que os do primeiro. Para ele, a maior parte das soluções relativas à cultura em novos grupos e organizações derivam dos seus fundadores e de seus primeiros líderes. Na medida em que os grupos envelhecem e adquirem experiência, seus membros se responsabilizam por encontrar e transmitir as soluções. Cabe aos líderes, 
então, encontrar soluções e promover segurança ao grupo quando algo não funciona ou realizar mudanças drásticas quando a organização assim o desejar.

- As questões de adaptação externa e integração interna, embora independentes, estão inter-relacionadas. Os problemas de adaptação externa referem-se às formas encontradas pelo grupo para sobreviver no ambiente. Embora a experiência anterior do grupo o predisponha a perceber o ambiente de determinada forma, existem aspectos externos que estão fora desse controle. As premissas definidas pelos fundadores da organização embasarão a maior parte das respostas que serão dadas para tais problemas, embora, com o tempo e a experiência do grupo, algumas dessas premissas possam ser modificadas, mas até certo ponto. Também a integração interna reflete a cultura dos fundadores e dos atuais líderes, as experiências anteriores dos membros do grupo e os eventos vivenciados. Com isto, Schein acredita que cada cultura organizacional tende a ser única, mesmo que as questões do entorno sejam comuns.

- Schein acredita que a cultura se instala de fato quando se deixa de questionar um dado, pois seus pressupostos tornaram-se inquestionáveis. Nesse sentido, é estável e, como tal, a essência da cultura não se modifica ou se modifica muito lentamente.

- Por ser considerada inquestionável, a cultura transmite aos novos membros o pressuposto de como é a organização. Esse processo dá oportunidade aos membros de testarem, ratificarem e reafirmarem a cultura e, por isso, tem importância estratégica no estudo da cultura organizacional.

- Embora a aprendizagem cultural não controle totalmente as percepções, pensamentos e sentimentos dos membros de um grupo, tende a influenciá-las fortemente, quanto mais tempo se vive dentro de uma determinada cultura. Por essa razão, quando o pesquisador pertence à mesma cultura mãe da organização que está sendo estudada, terá dificuldade para encontrar formas distintas de perceber, pensar e agir, pois tem o mesmo paradigma cultural. 


\subsubsection{A sociologia e o alternativo}

A opção por manter a definição de Schein no item anterior foi proposital, porque traz uma possibilidade de leitura voltada para hábitos e costumes de uma organização (ou "pressupostos básicos") que não está necessariamente relacionada a dados que foram comprovados cientificamente ou que são comuns à gestão na maioria das organizações.

No que tange ao objeto de investigação desta pesquisa, a cultura de uma organização pode ser um agente que facilita ou dificulta a utilização de ferramentas alternativas. Quando a cultura é favorável a testar formas alternativas de gestão, tende a aceitar novas práticas (e, quiçá, ferramentas dessa natureza) e a considerar que atendem aos seus objetivos, vindo a incorporá-las à sua rotina. Quando os valores são incompatíveis, dificilmente aceitará sequer testar práticas dessa natureza.

\subsection{A dimensão holística na teoria das organizações}

O objetivo deste tópico é analisar a visão holística, a partir de seus principais autores, e mostrar sua relação com as ferramentas alternativas.

Holismo vem do grego holos, que significa o todo, completo, inteiro, não-fragmentado. Em inglês, a palavra tem a mesma raiz de whole (inteiro). O termo foi utilizado pela primeira vez, segundo Petroni (1988, p. 17), no ano de 1928, por Smuts, no livro Holism and Evolution, visando abordar sistemas filosóficos que eram tratados em seu todo e não em suas partes. Segundo esse autor, ao se analisar um sistema, era importante verificar como as partes se relacionavam entre si tanto quanto separadamente. Holismo, segundo Park (2000, p. 234) é a perspectiva de observar a organização como uma totalidade, ou seja, "[...] a concepção de que todos os sistemas - físicos, biológicos e sociais - se compõem de subsistemas inter-relacionados. O todo não é simplesmente a soma das partes, e o próprio sistema só pode ser explicado com a globalidade".

Para Weil (1995, p. 88), trata-se de uma visão no qual indivíduo, sociedade e natureza compõem um conjunto que é "indissociável, interdependente e em constante movimento". Nesse sentido, mais do que as partes do sistema se encontrarem no todo, conforme o autor 
"os princípios e leis que regem o todo se encontram em todas as partes", em uma perspectiva de totalidade do ser, que o torna indissolúvel, que suscita os autores ligados a ela, a uma dimensão para além do próprio homem.

Catanante (2002 p. 516), analisando o desenvolvimento das pessoas da organização na dimensão holística, complementa: ele deve abarcar não apenas as dimensões racional, emocional e social, mas também a dimensão espiritual. Em outro estudo, Canfield apud Catanante (2000, p. 22) conceitua espiritualidade como o estar "consciente da divindade presente em cada coisa, em cada situação, em cada pessoa - conhecida ou desconhecida”.

Além disso, estabelece uma correlação entre as dimensões acima que, para ela, são essenciais ao ser integral e à vida no planeta: o social vincula-se ao elemento ar (como se vê e como se é visto pelos outros); o emocional vincula-se ao elemento água (suas reações e emoções); o espiritual vincula-se ao elemento fogo (seus propósitos na vida e as lições que aprende e/ou ensina) e, finalmente, o racional, que se relaciona ao elemento terra (a consolidação e as realizações).

Schrage (2000, p. 306), referindo-se à espiritualidade, avalia que existe uma linha tênue entre esta e a superstição que está tomando conta do mundo do trabalho. Mais do que isso, não basta aos trabalhadores se sentirem produtivos e eficazes e, na perspectiva da visão científica apregoada pela administração, restringirem-se a discutir quanto vale um dia do seu trabalho. Na sociedade pós-moderna, a busca é pelo sentido do trabalho.

Algumas empresas procuram canalizar para si essa discussão, seja através da prática da filantropia ou do voluntariado, seja na busca de tornar a luta pela sobrevivência da empresa a própria causa ou ainda mostrando a nobreza de sua missão em relação à sociedade. De qualquer modo, há uma contradição entre a perspectiva gerencial voltada para a racionalidade e a produtividade, em relação aos rituais voltados para a fé e o irracional.

Weil (1995, p. 21) questiona o distanciamento entre a ciência, a tecnologia e a ética. Isso vem se processando, na visão do autor, como consequiência da separação entre ciência, arte, filosofia e tradições, o que o leva a propor o desenvolvimento de uma perspectiva de unidade ou totalidade como um projeto de pesquisa e formação interdisciplinar. 
O modelo adotado por Weil (op.cit., p. 65) fundamenta-se nas teorias que descrevem o universo como um holograma, no qual "em todas as partes se reencontra o mesmo sistema que forma o todo". O universo é composto de uma mesma energia que se manifesta sob a forma de matéria. Contudo, ninguém vê essa energia, embora ela seja conhecida mediante suas manifestações.

Conforme Weil (op.cit.), o ser humano, a sociedade e, em conseqüência, também as organizações atuam como se fossem esse microcosmo e, por esta razão, reproduzem o sistema energético que representam: tanto podem caminhar no sentido da destruição como da paz. Quando o sentido é da destruição, o homem usa suas emoções na direção da raiva, apego, ciúmes, orgulho, medo. Quando no sentido da paz, direciona-se para o amor, a alegria, a compaixão e a eqüidade. A mesma relação acontece com a natureza e a sociedade.

\subsubsection{Espiritualidade e a visão holística}

A espiritualidade é apresentada como uma dimensão tão importante quanto as dimensões social, racional e emocional, na visão holística.

Segundo Catanante (2002, p. 523), espiritualidade significa "fazer com excelência, cumprindo uma missão muito mais voltada à própria motivação de fazer diferença no mundo do que à busca da aprovação dos outros ou a recompensas imediatas”.

Para ela, a espiritualidade não se restringe à realização de eventos, seminários ou treinamentos eventuais nos quais, se acredita, terão o poder de tornar a empresa um paraíso. "Espiritualidade é um valor, uma crença que precisa ser compreendida em toda a organização, a começar pela alta direção”. (Catanante, op.cit., p. 523). A autora cita como exemplos do que considera serem ações direcionadas para a prática da espiritualidade os programas de auto-conhecimento, liderança holística, serviço voluntário, atendimento a instituições ou comunidades carentes, mutirões, etc.

Uma compreensão semelhante a esta é adotada por empresas norte-americanas, embora de forma mais pragmática e focada em programas de benefícios. Cole (1998, p. 9) cita a Johnson \& Johnson, dos Estados Unidos, que desenvolve um amplo programa voltado ao trabalho e à família dos empregados que inclui apoio à recolocação de cônjuge de 
empregados, à adoção de filhos, ao controle do tabagismo, dentre outros. Tais programas foram desenvolvidos a partir dos valores e crenças apregoados pela organização, que considera como suas principais responsabilidades, por ordem, os clientes, os empregados, a comunidade e, por último, os acionistas. A justificativa é que, se os três primeiros forem supridos, certamente os acionistas obterão os resultados esperados. Cole (op.cit) refere-se ao consultor Stephen F.Boehlke; este acredita que os empregados devem sentir-se conectados aos resultados e estratégias das organizações, em uma perspectiva de ganha-ganha. $\mathrm{Na}$ reportagem Does your business have a soul (1998, p. 8), considera-se que a dimensão espiritualidade na organização deve supor pesquisas de ambiência, cujo resultado sejam ações que de fato interessem aos empregados, como a redução de níveis hierárquicos, treinamentos voltados para o desenvolvimento dos talentos e envolvimento dos empregados nas estratégias de negócios.

Embora a dimensão espiritualidade necessariamente não incorpore o desenvolvimento de práticas alternativas na organização e a preocupação caminhe em direção à prática efetiva dos valores presentes no discurso ético, essa visão mostra a emergência de uma nova forma de compreender o indivíduo na organização e, como consequiência, abre as portas para o desenvolvimento de ferramentas alternativas.

A maior parte das ferramentas alternativas atuais foi concebida a partir da dimensão holística. A crença de que o homem é um ser total e indissolúvel e que uma parte contém em si os elementos do todo, são fundamentais para se entender as razões pela quais se propõe a incluir a dimensão espiritual no contexto organizacional.

\subsection{A dimensão da administração e a teoria das organizações}

Este tópico apresenta a visão de alguns autores sobre a gestão de pessoas, ressaltando a importância da diferença entre o conceito formulado pelo cientista e o da moda, como um teste de mercado. A seguir, discutem-se critérios para se entender o conceito de qualidade de vida no trabalho, uma das áreas em que são adotadas práticas alternativas. 


\subsubsection{Gestão de pessoas}

Para análise deste tópico, cita-se a visão de três autores, que tratam do tema gestão de pessoas.

\subsubsection{Organização por processos}

Chiavenato (1999, p. 18) sugere uma mudança em relação ao que denomina de organização funcional tradicional do órgão de Recursos Humanos (RH) para uma abordagem sistêmica, tirando o foco da tarefa e voltando-o para processos, dos meios em direção aos resultados, da atenção aos cargos individualizados para a concepção de equipes autônomas e multidisciplinares. Para o autor, Administração de Recursos Humanos (ARH) moderna torna-se uma função de staff; e a gestão das pessoas é descentralizada para as demais gerências de linha. A partir de então, a ARH e as gerências tornam-se parceiras estratégicas.

\subsubsection{Administração Estratégica de Recursos Humanos (AERH)}

Marras (2000, p. 24) divide a gestão da área de RH em dois momentos: tradicional e estratégico. O primeiro é composto de quatro grandes fases evolutivas. Tose apud Marras (op.cit., p. 26) divide essa primeira fase, que ele chama de Administração de Recursos Humanos Tradicional, de acordo com a época, a saber: contábil (antes de 1930); legal (de 1930 a 1950); tecnicista (1950 a 1965) e administrativa (1965 a 1985). O segundo momento é composto da fase estratégica da Administração de Recursos Humanos (AERH), iniciada em 1985 e que perdura até a fase atual.

As principais características da fase atual, segundo o autor (op.cit., p. 253) são:

i. Mudança na posição orgânica, agora não mais como linha na hierarquia e sim como staff.

ii. Passa a participar e assessorar a formação das macro-diretrizes da empresa, agregandolhe valor através do capital humano existente na organização. 
iii. Formação de "espelhos", ou seja, talentos humanos que atuarão como agentes multiplicadores das mudanças e do estabelecimento de nova cultura organizacional.

iv. Realização de um processo de desenvolvimento organizacional.

\subsubsection{Desenvolvimento humano}

Dutra (2002, p. 17) caracteriza a área de Gestão de Pessoas como "um conjunto de políticas e práticas que permitem a conciliação de expectativas entre a organização e as pessoas para que ambas possam realizá-las ao longo do tempo".

Para dar conta desta visão, Dutra (op.cit.) mostra que a área de gestão de pessoas vem apresentando, ao longo de sua história, um movimento de focalização e aperfeiçoamento de seu modelo, que ele divide em três momentos. O primeiro ocorre com Fayol e a abordagem funcionalista, ao considerar essa área como uma função organizacional, o que contribui para entender o posicionamento da área na empresa. O momento seguinte, da abordagem sistêmica, situa a área em sua interação com as demais áreas funcionais, bem como a interação entre as políticas e as práticas. O terceiro momento procura tornar claro o papel da pessoa e seu movimento em direção à empresa. Dutra (op.cit.) a denomina de visão do desenvolvimento humano.

A proposta do autor tem como base três direções: a aprendizagem das pessoas e da organização; a dimensão da pessoa, que é aceita como um ser único e integral; e, finalmente, a noção de competência, composta na capacidade de entrega da pessoa, bem como do conjunto de qualificações que ela possui.

Dutra (op.cit.) propõe um novo modelo de gestão de competências que incorpora o papel das pessoas, às quais cabe gerir a sua carreira e seu desenvolvimento, e o papel das empresas, que devem abrir espaços, estimular o desenvolvimento das pessoas e dar suporte para que se estabeleça uma nova relação. O modelo proposto apresenta três processos-chave e um processo de apoio, a saber: 
a) Movimentação que inclui captação, internalização, transferências, promoções, expatriação e recolocação.

b) Desenvolvimento, que inclui captação, carreira e desempenho; e,

c) Valorização, que inclui remuneração, premiação, serviços e facilidades.

d) Processos de apoio: informação, comunicação, relações sindicais e relações com a comunidade.

O suporte a esse novo modelo tem como base:

a) Capacidade de entrega para a empresa;

b) Padrões de complexidade das atribuições e responsabilidades como elemento de diferenciação; e,

c) Espaço ocupacional, ou seja, a correlação existente entre complexidade e entrega.

A análise feita por estes autores, embora em espaços de tempo exíguos entre uma publicação e outra, mostra quanto as mudanças na gestão de pessoas têm sido rápidas e em profundidade: o primeiro relata mudanças mais voltadas para a estrutura hierárquica e de postura dos atores envolvidos na gestão de Pessoas; o segundo volta sua atenção para aspectos de ordem estratégica; o terceiro propõe um novo modelo centrado na entrega das pessoas e da organização.

A percepção da ocorrência das mudanças foi detectada em estudo realizado por Fischer (2001, p. 9), que ao examinar 136 artigos de autores de distintas nacionalidades constatou relatos, detecção ou defesa de mudanças nessa área. No Brasil, o autor refere que nove entre dez formadores de opinião ligados à área de RH consideram que ocorreram alterações nas políticas e práticas de gestão no período de dez anos.

Esses dados, por si só, evidenciam que a antiga denominação de RH tende a cair no desuso e ser substituída por gestão de pessoas. 
Contudo, cabe aqui pontuar a análise do tema realizada por Fischer (op.cit) que joga luz na proposta de Dutra (op.cit.) e esclarece porque se trata de um "modelo" de gestão de pessoas. Segundo ele, nesse modelo, a empresa não pode criar uma área de gestão de pessoas que se responsabilize pelo trato do comportamento humano, uma vez que essa ação provém de distintas instâncias organizacionais. O que ela pode fazer é propor um modelo que contemple suas expectativas acerca desse comportamento; estimular esse comportamento e não gerá-lo e encarar os indivíduos que vão produzir esses comportamentos como pessoas e não como recursos.

Finalmente, cabe ressaltar a discussão de Fischer (op.cit, p. 11) sobre a diferença entre conceito e moda, no âmbito da administração de empresas. O conceito é considerado verdadeiro "quando guarda estreita fidelidade com os pressupostos que norteiam seus estudos". Trata-se do teste do cientista. A moda refere-se ao "teste do mercado", em que se comprova a verdade "pelo grau de aceitação e de generalização desse mesmo conceito por parte das empresas" e, nesse caso, embora não deva ser evitada ou condenada, a priori, deve ser identificada e monitorada.

Os pontos aqui levantados foram objeto de atenção, no desenvolvimento deste estudo, uma vez que a gestão de pessoas permanece em fase de rápidas mudanças. Por esse motivo, a discussão das ferramentas alternativas deve ser feita considerando a formação de um modelo conceitual e não com o objetivo de desencadear uma nova moda.

\subsubsection{Qualidade de vida no trabalho (QVT)}

Pesquisas vêm sendo feitas com o objetivo de encontrar ações que tornem mais saudável o ambiente organizacional. Esse movimento fez surgir estudos na área de qualidade de vida no trabalho (QVT).

Para Limongi-França (1996, p. 8) QVT é “O conjunto das ações de uma empresa que envolve a implantação de melhorias e inovações gerenciais, tecnológicas e estruturais do ambiente de trabalho". 
A autora (op.cit.) cita alguns conceitos desenvolvidos por diferentes estudiosos, ao longo dos anos, como Drucker, que enfatiza a responsabilidade social da empresa; Walton, que destaca a humanização e a responsabilidade social; Werther e Davis, que focam a valorização dos cargos, mediante análise de elementos organizacionais, ambientais e comportamentais; Lippitt e Camacho, que vêem a QVT como trabalho, crescimento pessoal e sobrevivência com dignidade, segurança, participação e perspectiva de futuro; e Dantas, que destaca a promoção da saúde.

Para Walton (1975), os critérios adotados para definir o conceito de qualidade de vida incluem as oito categorias descritas a seguir.

1. Compensação justa e adequada: refere-se à remuneração recebida dentro de padrões organizacionais baseados na cultura da empresa e em modelos ideológicos. Indicadores: salário e jornada de trabalho.

2. Condições de trabalho seguras e saudáveis: horários razoáveis, condições físicas que reduzam riscos de danos e doenças; existência de critérios que respeitem idade, estrutura física. Indicadores: ambiente físico e salubridade.

3. Oportunidades imediatas para desenvolver e usar as capacidades humanas: considerar potencialidades, e desafio pessoal-profissional. Indicadores: autonomia, estima, capacitação múltipla e informações sobre o trabalho.

4. Oportunidades futuras para o crescimento contínuo e a garantia de emprego: oportunidade de carreira, através da educação formal, uso do conhecimento, das habilidades expandidas e das habilidades recém-adquiridas. Indicadores: carreira, desenvolvimento pessoal e estabilidade no emprego.

5. Integração social na organização: corresponde à ausência de preconceitos, de modo que se crie a comunidade na organização. Indicadores: ausência de preconceitos, habilidade social e valores comunitários. 
6. Constitucionalismo na organização: noção de cidadania, envolvendo aspectos relacionados aos direitos e deveres legais dos cidadãos. Indicadores: direitos garantidos, privacidade e imparcialidade.

7. Trabalho e espaço total na vida do indivíduo: valorização de outros pilares que sustentam a vida das pessoas, como suas relações com a família, lazer, interesses comunitários e religiosos. Indicadores: liberdade de expressão, vida pessoal preservada e horário previsível.

8. Relevância social do trabalho: ações referentes ao meio ambiente, oportunidade de emprego, atendimento das necessidades sociais de saúde, transporte, comunicação, educação e higiene. Indicadores: imagem da empresa e responsabilidade social da empresa.

Esse conjunto de critérios - cujos indicadores facilitam a compreensão e permite a comparação entre eles - fundamenta-se na dimensão organizacional. O foco está na humanização e na responsabilidade social, considerando o poder da empresa.

A leitura atenta dessas categorias, quando comparadas às dimensões psíquica, sociológica e holística, mostra que, na administração, apesar dos diferentes pressupostos, é factível estabelecer um diálogo entre elas, uma vez que objetivam, em última análise, compreender e possibilitar o desenvolvimento de ações para a melhoria da qualidade de vida no trabalho. Assim sendo, é possível depreender que:

1. O foco na responsabilidade social, proposto nos programas de QVT, converge para a proposta de paz social, estando em sintonia absoluta com o sentido de sinergia e de cooperatividade proposto por Weil.

2. As condições de trabalho, quando seguras e saudáveis para os trabalhadores, podem reduzir e até eliminar as causas do sofrimento no desenvolvimento das atividades.

3. Os programas de compensação, quando injustos, têm como conseqüência o desenvolvimento de doenças que atingem o corpo do ser humano. 
4. Oportunidades imediatas e futuras que estão compatíveis com o desenvolvimento da sabedoria aumentam o desejo e a motivação e reduzem o sentimento de desagregação do indivíduo no trabalho.

5. Os preceitos de integração social e constitucionalismo, totalmente compatíveis com os preceitos de justiça e solidariedade, estão em consonância com a aceitação da diversidade cultural.

6. O sentido da valorização de outros pilares de vida do indivíduo, cujo sentido está ligado à dimensão do ser em sua totalidade.

7. A preservação do espaço e da vida do trabalhador contribui para a integridade de sua personalidade e viabilizam sua inserção como cidadão.

8. Finalmente, a relevância social do trabalho, que está vinculada à noção de preservação da natureza e da própria sociedade.

A partir dessas premissas, é possível considerar que a qualidade de vida no trabalho pode ser alcançada quando se respeita o indivíduo em sua unicidade; atua-se para tornar seu ambiente de trabalho num local de desejo e motivação; e, em síntese, para que se sinta como um ser integral.

Nesse sentido, caminham Kuramoti (1995, p. 48), ao descrever a aplicação da qualidade total na dimensão holística nas organizações, e Ribeiro (1993, p. 43) ao propor a implementação de programas para as famílias dos empregados, a análise do clima e da cultura organizacional. Nesse sentido, caminham as organizações quando buscam ferramentas alternativas que contribuam para a gestão das pessoas na perspectiva de melhorar a qualidade de vida de seus empregados.

Vianna (1992, p. 10), analisando essa mudança na estratégia organizacional, assinala que, nos anos 80, se procede a um grande despertar de homens e mulheres ao verificar que enquanto a tecnologia médica vem possibilitando o aumento na expectativa de vida, o coeficiente de felicidade tem despencado. 
As pessoas, em função do estresse da vida moderna, da violência, das drogas, passam a questionar sua qualidade de vida e saem em busca de alternativas para alterar ou, pelo menos, minimizar essa situação. Para Viana (op.cit), os anos 90 marcaram uma década de "culto ao corpo", e de crescimento da dimensão religiosa e espiritual em um segmento significativo da população. A empresa, que para ele é uma instituição intermediária entre aqueles seres humanos que produzem e aqueles seres humanos que consomem, é levada a mudar suas estratégias e se adaptar a essa nova situação.

\title{
2.7.3 A administração e o alternativo
}

Cabe conceituar agora sobre o que se entende, no âmbito desta pesquisa, por ferramentas ou práticas alternativas na dimensão da gestão das organizações. Segundo Bock apud Galvão (2000, p. 104):

\footnotetext{
"Implica reconhecer determinadas práticas como oficiais, como dominantes e reconhecer outras práticas como fora do oficial, das práticas cotidianas e comuns; implica uma escolha entre duas coisas, onde uma parece estar de acordo com as práticas dominantes e a outra é a que se escolhe como alternativa, que é também a que mais convém".
}

Para Galvão (op.cit., p. 107), ser alternativo não significa necessariamente um avanço:

\begin{abstract}
"Porque alternativa é sempre uma opção; é uma escolha que alguém ou um grupo faz entre duas ou mais coisas. Portanto, deverá estar de acordo com os valores de quem escolhe; com a finalidade que se colocou para o trabalho; coerente com o projeto que se tem; com a visão de homem e de mundo de quem escolhe. [...] atribuir o adjetivo alternativa a uma prática envolve um julgamento, que exige o conhecimento do projeto, dos valores, da finalidades, dos entraves ou barreiras que exigiram a busca do alternativo. E assim, de forma 'oficial' ou 'dominantes' a alguma prática, pois será aquela que está de acordo com as finalidades, projetos e valores dominantes na sociedade".
\end{abstract}

Este projeto assume prática alternativa na direção do não-dominante, cotidiano e comum na gestão de pessoas das organizações. Considera ainda como alternativas aquelas práticas não caracterizadas como cientificamente comprovadas e que, de modo geral, foram apresentadas à gestão de pessoas como contendo aplicações mais espiritualistas no sentido de artes adivinhatórias e/ou esotéricas.

Assume, no entanto, que, como ferramentas alternativas, estas precisam ser analisadas sob uma ótica crítica. Ou seja, indaga até que ponto sua aplicação pode contribuir para a 
melhoria na qualidade de vida dos trabalhadores, em sua busca pelo prazer e da unicidade e não do sofrimento e da visão segmentada.

\subsection{Práticas alternativas mais freqüentes}

Este tópico é dedicado a descrever práticas alternativas, à luz dos seus comentadores. Como o objetivo não é demonstrar a validade de cada uma dessas práticas, busca-se aqui apresentálas e analisar como podem ser utilizadas como ferramentas alternativas e adicionais na gestão de pessoas.

\subsubsection{Astrologia}

A astrologia é muito difundida no Brasil, principalmente através dos meios de comunicação popular, como é o caso do rádio e dos jornais, que mantêm colunas ou partes de programas destinados a informar as previsões para um determinado período (dia, semana, mês, ano). O costume de consultar os astros, porém, não está restrito ao País e tampouco é recente.

A época não é precisa, mas, segundo Burini (2002, p.30) os relatos de autores sobre o assunto mostram que o interesse do homem pelo conhecimento do cosmos remonta de 5000 a.C. a 3000 a.C., tendo sido encontradas pequenas tábuas com símbolos astrológicos na biblioteca de Assurbanipal, em Nínive, Babilônia. Contudo, segundo Ribeiro (1986, p. 19) o horóscopo mais antigo, feito para uma pessoa, data somente de 20 de abril de 409 aC.

Essa tentativa de associar o cosmos à relação de causa e efeito nas pessoas acompanhou praticamente todos os povos e em todos os continentes. A digressão histórica feita por Burini (op.cit., p. 31) mostra a astrologia na Grécia, Roma, no Egito, na China, na Índia, na América pré-colombiana, dentre outros. Segundo a autora, para maias e astecas havia uma sequiência de períodos ora de expansão, ora de destruição, que atingia tanto os destinos das pessoas quanto os destinos da humanidade.

A partir do século XX, a astrologia passou a ser amplamente difundida entre a população. Tudo começou pouco antes da Segunda Guerra Mundial, na França, quando o "fakir 
BRIMAN" criou um jornal que divulgava o horóscopo em uma de suas colunas. A idéia foi copiada por outros jornais e popularizou a técnica. Com o advento da informática, mapas astrológicos passaram a ser feitos por computador.

Se, de um lado, a astrologia passou a ser amplamente conhecida, por outro, perdeu sua característica original. Nas palavras de Burini (op.cit., p. 78):

\footnotetext{
"Uma caracterizada como comercial, que atende o grande público, uma autêntica 'astrologia a la carte'; a outra, voltada para um atendimento personalizado. Essa segunda, ocupa-se do autoconhecimento, que passa pela compreensão da estrutura humana" .
}

No que concerne à perspectiva da astrologia como arte divinatória ou ciência, é possível encontrar vasto número de publicações que, de modo geral, são editadas por especialistas na área e, por esta razão, defendem que se trata de uma ciência.

Do lado oposto, estão astrônomos de reconhecida importância nos meios científicos que questionam os postulados astrológicos. Para aqueles que defendem a sua validade, como March (1981, p. 15), a astrologia é "mãe" da astronomia. Enquanto a última é uma ciência objetiva; a astrologia é subjetiva. Segundo o autor (op.cit.), trata-se de uma ciência que investiga a ação dos corpos celestes sobre os objetos animados e inanimados, e sua reação a essa influência.

Para Hutin apud Burini (2002, p. 23), “é a arte divinatória baseada num conhecimento preciso dos movimentos dos astros na abóbada celeste em suposta relação com os episódios felizes e nefastos da vida humana”. Ribeiro (1988, p. 17), por sua vez, considera que pode ser tanto uma ciência quanto "a arte da mágica e misteriosa linguagem cósmica, quando o céu reflete-se no homem".

Já Oliveira Filho (2004, p. 2) concorda com Maffesoli, orientador de uma tese de doutorado na Université Sorbonne Paris ${ }^{9}$, para quem a astrologia é um fato social, um jogo de linguagem e não uma ciência. O autor vai além e cita os estudos relacionados a seguir, que corroboram a sua opinião:

\footnotetext{
9 "La situation épistémologique de l'astrologie, liée à l'ambivalence fascination/rejet dans lês sociétés postmodernes", tese de doutorado em sociologia da astróloga francesa Elisabeth Tessier.
} 
1. Pesquisa do psicólogo Bernard Silverman, da Michigan State University que, após estudar 2.978 casamentos e 478 divórcios, concluiu que casais cujos cônjuges são incompatíveis em termos astrológicos casam-se e divorciam-se com a mesma freqüência que aqueles compatíveis.

2. Em estudo desenvolvido pelo físico John McGervey, da Case Western University, que contemplou a biografia e a data de nascimento de 6.000 políticos e 17.000 cientistas, não houve alguma correlação entre a data de nascimento e a profissão.

3. Teste coordenado pelo físico Shawn Carlson, do Laerence Berkeley Laboratory, da Universidade da Califórnia, com 116 pessoas, que procurava compatibilizar o horóscopo completo de uma pessoa, que também preenchia um questionário de personalidade, previamente negociado com os astrólogos. A organização astrológica, responsável pelo calculo do horóscopo da pessoa, selecionava entre 3 questionários de personalidade aquele que corresponderia ao seu horóscopo calculado. O resultado mostrou que a taxa de acerto, cujos astrólogos previram que seria antecipadamente maior do que $50 \%$, foi de $35 \%$, ou seja, escolha ao acaso. Segundo Oliveira Filho (op.cit.), os resultados dessa pesquisa foram publicados no artigo A Doublé Blind Test of Astrology, em 1985.

4. Os astrônomos Roger Culver e Philip Ianna analisaram previsões publicadas de astrólogos conhecidos e de organizações astrológicas, durante um período de cinco anos. Os resultados mostraram que apenas $10 \%$ de três mil previsões envolvendo políticos, atores e outras pessoas famosas, se concretizaram.

5. Em pesquisa realizada durante sete anos, divulgada através da revista Veja (edição 1.638, $1^{\circ}$ mar. 2000, p.127) sob coordenação do professor Salim Simão do Departamento de Produção Vegetal da Universidade de São Paulo, concluiu-se que as fases da lua não têm efeito sobre o crescimento das plantas. $\mathrm{Na}$ mesma reportagem, o médico dermatologista Valcinir Bedin, presidente da Sociedade Brasileira para Estudos do Cabelo concluiu que a média de crescimento do cabelo é de um centímetro por mês, independentemente da fase lunar. 
Burini (2002, p. 19), por sua vez, não discute se a astrologia é arte ou ciência, e sim procura mostrar que "a tradição do conhecimento astrológico pode ser um instrumento auxiliar de compreensão do ser humano".

Mais do que isso, a autora relata que, até o século XVIII, astrologia e astronomia eram palavras sinônimas, tanto assim que, na etimologia da palavra astrologia, o significado refere-se à astronomia, responsável pelo estudo dos corpos celestes e seus movimentos: "astro" vem do grego astrum, que aponta para os corpos celestes, e "logia" é oriunda do grego logos, e significa estudo.

Este estudo caminhou paralelamente ao da autora, pois não se pretendeu aqui discutir ou validar os argumentos pró e contra a astrologia como uma ciência e, sim, avaliar sua utilização no ambiente empresarial e os resultados obtidos.

Falcão (2002, p. 548), centrando sua análise nas organizações, considera que a astrologia pode ser utilizada para auxiliar no planejamento estratégico, quando do estabelecimento de cenários; em marketing, na determinação de necessidades de mercado, estratégias propostas e datas para lançamento de produtos; na avaliação de sociedades e parcerias, bem como na viabilidade sobre a abertura de novos negócios; em recursos humanos, na gestão de talentos, através do diagnóstico de potencial, desenvolvimento de competências, ciclos profissionais; em finanças, apoiando a viabilidade de investimentos e aplicações e, finalmente, no alinhamento entre a visão da empresa, equipe e pessoa.

Tunick (2002, p. 1) relata a existência de uma Sociedade Internacional de Astrólogos Empresariais que estuda a astrologia financeira e empresarial. Segundo este, a consulta a astrólogos profissionais vem crescendo tanto nos Estados Unidos quanto na Europa. Boesen apud Tunick (op.cit.) considera que existe uma diferença entre esses povos: enquanto os americanos procuram conhecer o melhor momento para realizar seus investimentos financeiros de forma a lograr mais lucro, os europeus focam sua preocupação no negócio em si.

A Astrologia Empresarial fundamenta-se na análise do mapa astrológico, construído a partir da data e do horário da fundação de uma empresa. Segundo os especialistas, a partir desse estudo, é possível avaliar aspectos da empresa que a fortalecem ou restringem, dependendo 
do movimento dos planetas, bem como indicar o melhor momento para abrir um novo negócio ou lançar um novo produto, sugerir um investimento, realizar mudanças na administração da organização e contratar novos empregados.

Bernis (2000, p. 03) cita as principais aplicações da Astrologia Empresarial, dentre as quais, a relacionada a recursos humanos, palestras e treinamentos: "1. laudos para seleção de pessoal, 2. estudos de perfil de liderança, e, 3. diagnóstico de integração de equipes de trabalho". No que diz respeito a palestras e treinamentos, cita a astrologia relacionada à economia e à política e, finalmente, a realização de treinamentos comportamentais tendo por base a fundamentação astrológica.

No que se refere à utilização da astrologia como instrumento de apoio à seleção de pessoal, Hardin (1995, p. 66) discute a realidade americana. Nesse sentido, mostra que a escolha de uma pessoa a partir da análise de seu mapa astrológico poderia gerar problemas legais, pois evidenciaria a escolha pessoal sobre a escolha de qualificação profissional ou, ainda, a definição de um candidato a partir da análise dos astros. A alternativa seria, então, no limite, analisar se o candidato poderia trabalhar bem ou não com os demais empregados que compõem a equipe.

Quanto a itens como integração de equipes de trabalho, segundo Warren apud Caudron (1998, p. 64), a astrologia contribui a partir da análise da posição do sol na data do nascimento de uma pessoa, por influenciar seu caráter e seu temperamento. Segundo essa astróloga, pessoas que trabalham com outras que apresentam o sol em oposição ao seu tendem a ser mais produtivas.

Astrologia védica: Em Bombaim, na Índia, antigos textos hindus identificaram 27 espécies de árvores. Segundo esses textos, os sinais do zodíaco de uma pessoa estão relacionados a duas ou três das 27 constelações reconhecidas na astrologia védica e cada constelação relaciona-se a uma das 27 espécies de árvores. Conforme Louis (1999, p. b1), a utilização dessas árvores é terapêutica, por exemplo, reduzindo o estresse Para tanto, a pessoa deve refugiar-se sob a árvore que está relacionada ao seu signo. Segundo o artigo, a cidade de Bombaim construiu jardins astrais ao redor da cidade, cuja entrada é livre. 
Este estudo não encontrou empresas que façam uso da astrologia védica, razão pela qual o tema está sendo apenas citado.

\subsubsection{Astrologia ocidental/Astrologia oriental}

Os objetivos são idênticos, ou seja, compreender a interferência do cosmos na vida do ser humano. A forma de calcular e analisar a pessoa, contudo, na astrologia ocidental e na oriental (ou chinesa), é diferente, conforme mostra White (1986, p. 15).

Os ocidentais dividem o tempo em séculos de cem anos, e em décadas. O ano é dividido em 12 vezes, de acordo com a lua e, a cada mês de 28 ou 30 dias recebe uma denominação astrológica, de acordo com os signos celestes, a saber: áries, touro, gêmeos, câncer, leão, virgem, libra, escorpião, sagitário, capricórnio, aquário, peixes.

A astrologia ocidental é composta por quatro elementos da natureza: fogo, terra, ar e água. Os signos compõem cada grupo de elementos, que são divididos em três distintas qualidades, e regentes de um planeta, conforme Quadro 2.

\section{Quadro 2 - Regentes astrológicos}

\begin{tabular}{|l|l|l|l|}
\hline \multicolumn{1}{|c|}{ Signo } & Planeta regente & Elemento regente & Qualidade \\
\hline Áries & Marte & Fogo & Cardeal \\
\hline Touro & Vênus & Terra & Fixo \\
\hline Gêmeos & Mercúrio & Ar & Mutável \\
\hline Câncer & Lua & Água & Cardeal \\
\hline Leão & Sol & Fogo & Fixo \\
\hline Virgem & Mercúrio & Terra & Mutável \\
\hline Libra & Vênus & Ar & Cardeal \\
\hline Escorpião & Plutão & Água & Fixo \\
\hline Sagitário & Júpiter & Fogo & Mutável \\
\hline Capricórnio & Saturno & Terra & Cardeal \\
\hline Aquário & Urano & Ar & Fixo \\
\hline Peixes & Netuno & Água & Mutável \\
\hline
\end{tabular}

$\mathrm{Na}$ astrologia ocidental, ainda, a pessoa, física ou jurídica, tem um mapa astrológico próprio, baseado na data, local e horário de seu nascimento, se pessoa física, ou constituição, se pessoa jurídica. O mapa astrológico é dividido em 12 casas, que, por sua vez, são ocupadas por um signo diferente. De acordo com o local, data e hora do nascimento, os planetas estarão em um signo e casa astrológica específica (Figura 2). 


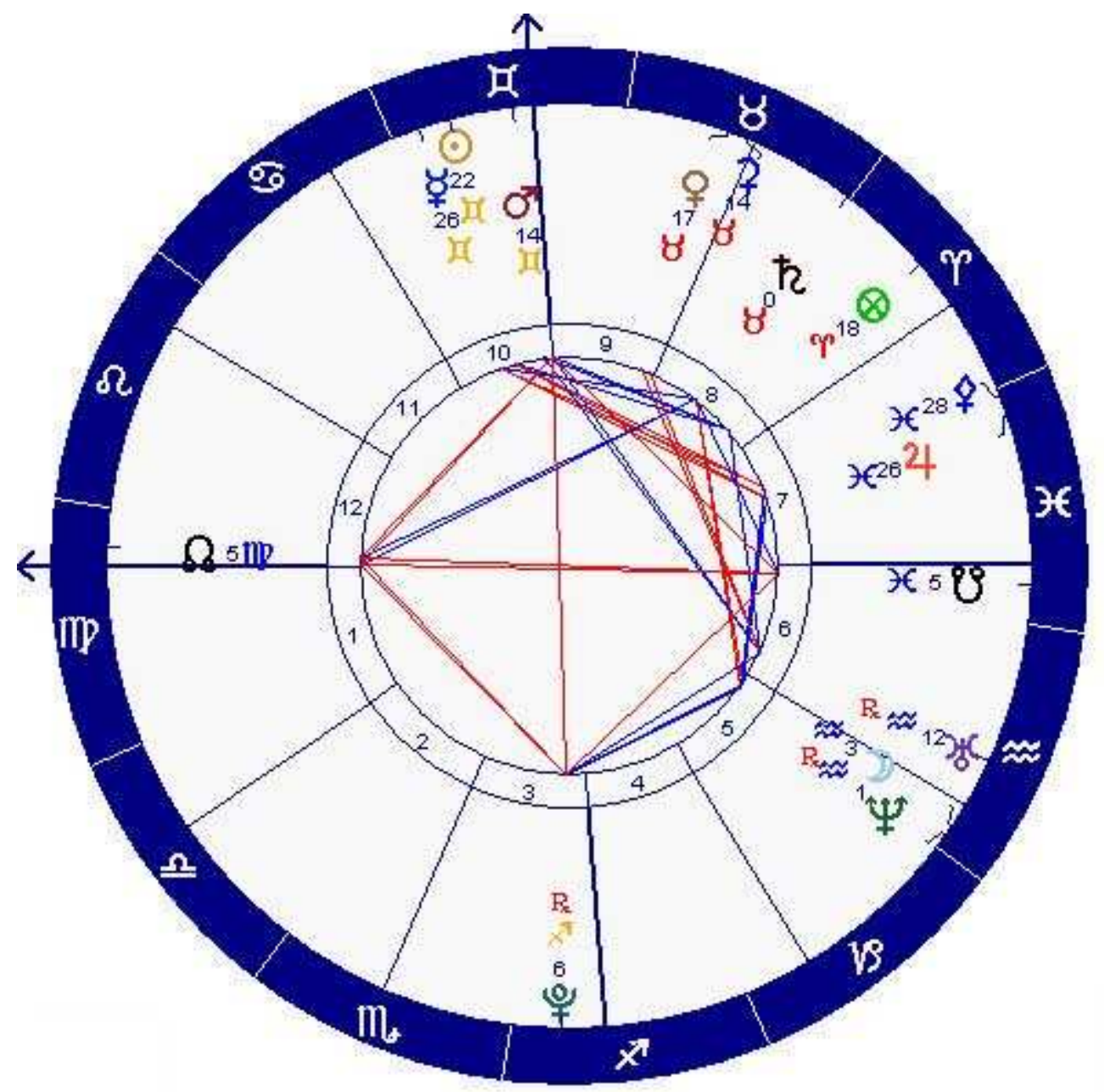

Figura 2 - A mandala astrológica

A análise é feita a partir do cálculo do mapa astrológico individual e indica características, facilidades e desafios que a pessoa tenderá a enfrentar ao longo de sua vida. A partir dele, os astrólogos podem realizar também a sinastria, ou comparar aspectos entre os mapas e verificar em que aspectos eles são harmoniosos e em que são desafiadores.

Já os chineses dividem o tempo em períodos de 60 anos e subdivididos em dodécadas, ou seja, 12 anos. Cada ano recebe o nome de animal, a saber: rato, boi, tigre, gato, dragão, cobra, cavalo, cabra, macaco, galo, cão e porco. O ciclo chinês encerra-se ao final de 12 anos. 
A astrologia chinesa considera cinco elementos regentes e duas qualidades, conforme Quadro 3.

Quadro 3 - Astrologia chinesa

\begin{tabular}{|l|l|l|}
\hline Animal & \multicolumn{1}{|c|}{ Elemento } & Qualidade \\
\hline Rato & Água positiva & Yin \\
\hline Boi & Água negativa & Yin \\
\hline Tigre & Madeira positiva & Yang \\
\hline Gato & Madeira negativa & Yin \\
\hline Dragão & Madeira positiva & Yang \\
\hline Cobra & Fogo negativo & Yang \\
\hline Cavalo & Fogo positivo & Yang \\
\hline Cabra & Fogo negativo & Yang \\
\hline Macaco & Metal positivo & Yin \\
\hline Galo & Metal negativo & Yang \\
\hline Cão & Metal positivo & Yin \\
\hline Porco & Metal negativo & Yin \\
\hline
\end{tabular}

Tanto a astrologia oriental como a astrologia chinesa consideram que, a cada momento da vida, a depender dos aspectos astrológicos, a pessoa física ou jurídica terá maior facilidade ou dificuldade para lidar com aspectos de sua existência (por exemplo, a compra de um imóvel, a melhoria ou a piora do status, dentre outros).

\subsubsection{Numerologia}

Uma das "ciências divinatórias"; "ciência dos números"; "aplicação da ciência das vibrações sonoras”. Essas são as formas pelas quais se referem à numerologia Cissay (1984, p. 9) e Camaysar (1993, p. 9). Embora se conheça pouco sobre a origem desta prática, na antiguidade, a numerologia, como é conhecida atualmente, foi desenvolvida a partir dos fundamentos propostos por Pitágoras, cujas idéias o levaram a utilizar a teoria dos números "para explicar o sistema cósmico e a criação". (Camaysar, op.cit)

O estudo parte do nome e/ou da data de nascimento de uma pessoa ou empresa. A partir da numerologia, segundo Marin (2002, p. 584) é possível "decodificar” a mensagem que aquele nome ou número simboliza. A data de nascimento reflete, segundo a autora, ciclos de vida.

Para proceder à análise, o especialista atribui um valor numérico de um a nove, a cada uma das letras do alfabeto, de forma seqüencial (Quadro 4). 
Quadro 4 - Numerologia

\begin{tabular}{|c|c|c|c|c|c|c|c|c|}
\hline $\mathbf{1}$ & $\mathbf{2}$ & $\mathbf{3}$ & $\mathbf{4}$ & $\mathbf{5}$ & $\mathbf{6}$ & $\mathbf{7}$ & $\mathbf{8}$ & $\mathbf{9}$ \\
\hline $\mathrm{A}$ & $\mathrm{B}$ & $\mathrm{C}$ & $\mathrm{D}$ & $\mathrm{E}$ & $\mathrm{F}$ & $\mathrm{G}$ & $\mathrm{H}$ & $\mathrm{I}$ \\
\hline $\mathrm{J}$ & $\mathrm{K}$ & $\mathrm{L}$ & $\mathrm{M}$ & $\mathrm{N}$ & $\mathrm{O}$ & $\mathrm{P}$ & $\mathrm{Q}$ & $\mathrm{R}$ \\
\hline $\mathrm{S}$ & $\mathrm{T}$ & $\mathrm{U}$ & $\mathrm{V}$ & $\mathrm{W}$ & $\mathrm{X}$ & $\mathrm{Y}$ & $\mathrm{Z}$ & \\
\hline
\end{tabular}

O estudo baseia-se em atribuir um número ao nome e à data de nascimento de uma pessoa, endereço ou, neste caso, uma organização, e analisar as "energias" que a ele corresponde, segundo a análise numerológica.

A utilização dessa prática na empresa permite, segundo Marin (op.cit), diagnosticar características de identidade, habilidade e postura das pessoas; o que pode auxiliar nos processos de tomada de decisão, formação de equipes de alto desempenho, diagnóstico para capacitação e desenvolvimento individual ou grupal, recrutamento e seleção, formação de parcerias empresariais, bem como na escolha do nome adequado para abertura de uma empresa ou organização.

\subsubsection{Feng shui}

O feng shui (pronuncia-se "fong-chuei") é uma arte desenvolvida pelos chineses, há aproximadamente cinco mil anos. Conforme Bartlett (2000, p. 15), feng significa vento e shui significa água, responsáveis, para aquele povo, por mostrar que espécie de energia atuava sobre a montanha ou a paisagem. Segundo Goldkorn (1999, p. 13), constatações dessa natureza surgiram a partir da observação que faziam os agricultores que cuidavam das lavouras de arroz e verificavam que a colheita era mais ou menos abundante, dependendo do local onde as sementes haviam sido plantadas.

Segundo Craze (1998, p. 11), feng shui é uma combinação de elementos, quais sejam, magia, adivinhação, design de interiores, filosofia e bom senso. Trata-se de uma prática, ou sistema, utilizada para auxiliar na organização dos espaços, de forma a harmonizá-los. Para Occhialini (2002, p. 615), é uma arte que procura alinhar um espaço que tanto pode ser de uma casa, como de trabalho às "forças da natureza, com o propósito de gerar harmonia" na vida daqueles que utilizam aquele local. Trata-se de melhorar a utilização da energia Chi (é uma força invisível considerada vital, que não está visível, não pode ser percebida pelos 
órgãos dos sentidos, mas cujos efeitos, segundo a crença chinesa, podem ser percebidos). Conforme Craze (1998, p. 17), a energia Chi, segundo a acupuntura, também circula no corpo.

A técnica, a exemplo de outras práticas chinesas, baseia-se no sentido de equilibrar a força do vento "Yang" (ativa, dinâmica, externa, clara, no alto) e a força da água "Yin" (passiva, receptiva, interna, obscura, embaixo). Tais forças são complementares, tanto assim que um contém um elemento do outro (Figura 3). Dessas forças, outras surgem, conforme Figura 4, num total de oito elementos, ou trigramas, formado por três linhas paralelas.

As linhas superiores de cada um dos trigramas representam a dualidade que existe entre o firmamento e a criação (o yin e/ou yang). As linhas do meio simbolizam a união do firmamento e da criação, que dão origem às quatro estações e aos pontos cardeais do compasso. As linhas inferiores representam as pessoas. Os oito trigramas são a base dos 64 hexagramas, que compõem o I Ching, outra prática chinesa.

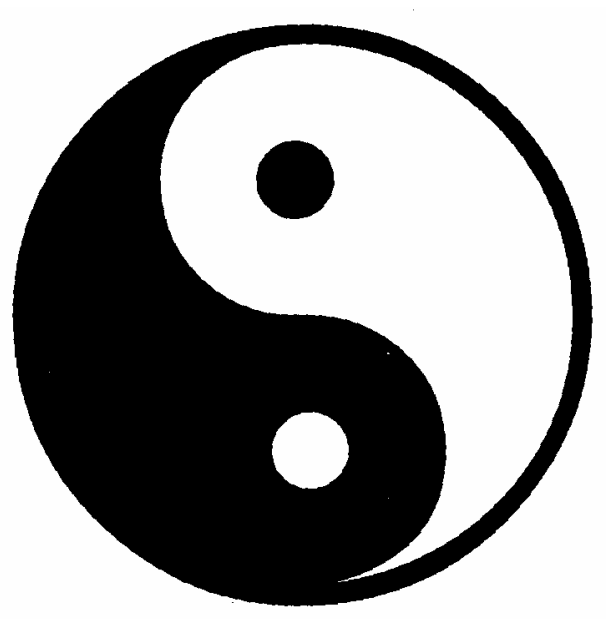

Figura 3 - Ciclo criativo 


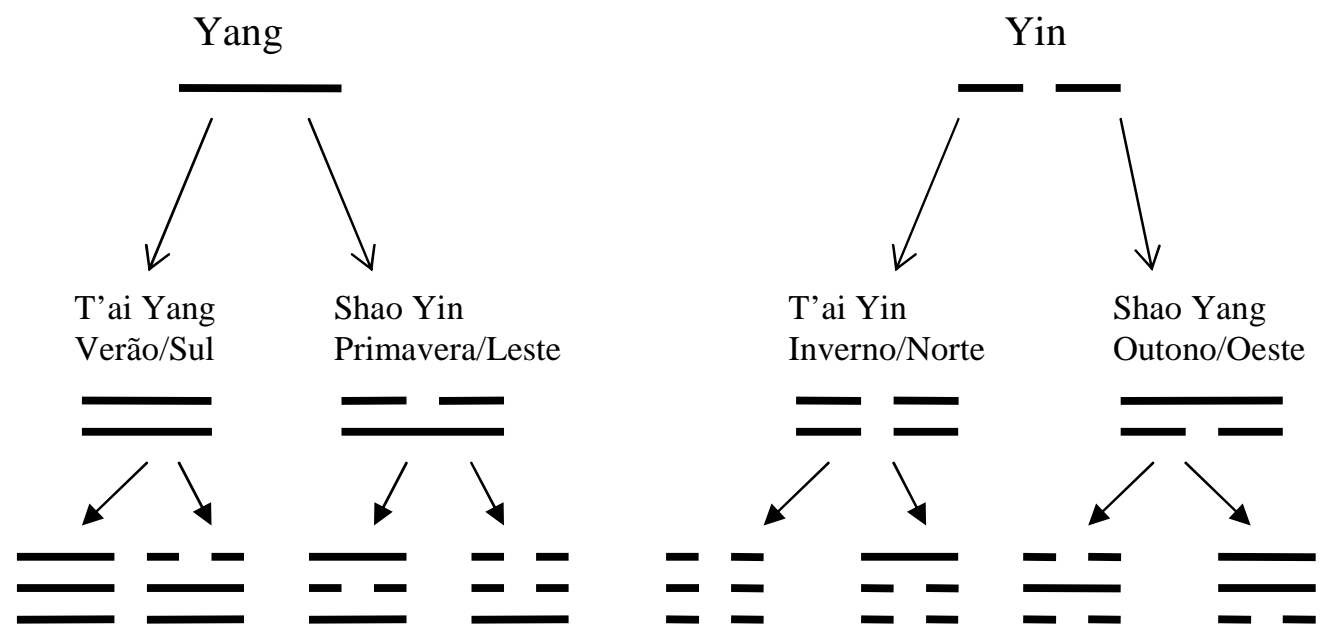

Figura 4 - Elementos dofeng shui

O estudo do feng shui está baseado em cinco elementos, os quais, para os antigos chineses, compunham toda a natureza e constituem um ciclo de criação e outro de destruição. São eles: fogo, terra, metal, água e madeira. $\mathrm{O}$ ar foi desconsiderado pelos chineses, na medida em que vapor e ar, para eles, fazem parte do elemento água.

No ciclo de criação, o fogo cria a terra, esta cria o metal, que se liquefaz, tornando-se água a qual, por sua vez, nutre a madeira que, ao queimar, cria o fogo. No ciclo de destruição, o fogo derrete o metal; este destrói a madeira que, por sua vez, se nutre da terra, que bloqueia a água e esta, por fim, apaga o fogo.

Outro fundamento utilizado no feng shui é o ba-guá (Figura 5), composto de oito áreas, cada qual com um significado específico. O ba-guá é colocado sobre a planta baixa do edifício e, a partir daí, o especialista analisa e orienta como organizar cada parte.

A disposição na planta baixa é feita, para os adeptos da chamada escola do chapéu negro, colocando-se a área do trabalho na parte que contém a entrada principal do edifício analisado. Para os adeptos da escola da bússola, é necessário que a área do trabalho fique voltada para o Norte, conforme Quadro 5. 
Quadro 5 - Os oito locais do feng shui

Sudeste

Sul

Sudoeste

Leste

\begin{tabular}{|c|c|c|}
\hline Abundância & Sucesso & Felicidade \\
\hline Sabedoria & & Prazer \\
\hline Família & Trabalho & $\begin{array}{c}\text { Novas } \\
\text { Metas }\end{array}$ \\
\hline
\end{tabular}

Oeste

Nordeste

Norte

Noroeste

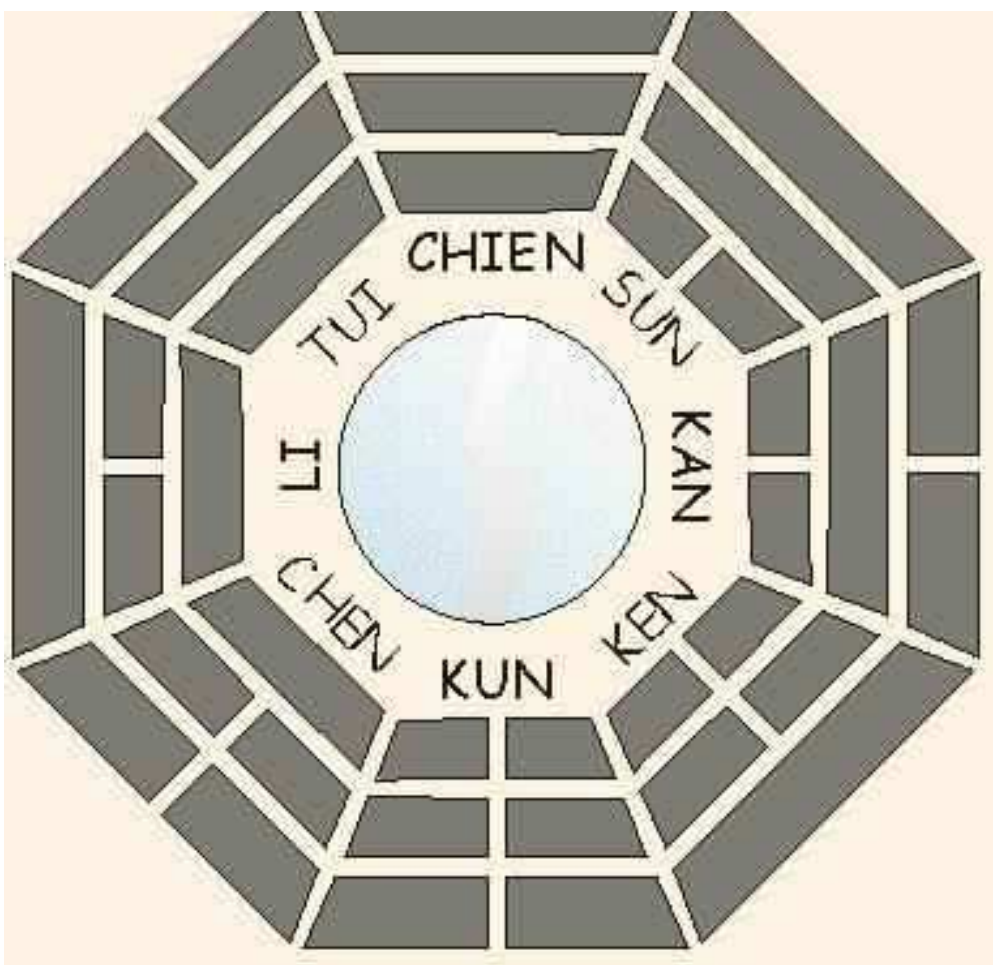

Figura 5 - Ba-guá 
Essa prática é utilizada nas empresas com o objetivo de expandir as oportunidades de negócio, melhorar o relacionamento grupal, atrair e intensificar o fluxo de dinheiro. A análise é realizada a partir da localização do prédio no qual a empresa está instalada. São analisadas também a disposição das pessoas que trabalham na organização, e a atividade de cada área de trabalho.

A técnica faz parte da cultura chinesa e, como tal, é respeitada também no ambiente empresarial de países asiáticos. Segundo Hobson (1994, p. 22), algumas empresas em Taiwan, não adquirem uma nova propriedade ou abrem um novo negócio sem antes consultar o calendário lunar e um especialista em localização de feng shui. Segundo o autor, nos anos 80, a ilha possuía entre 20 e 30 mil desses especialistas. Atualmente, na moderna cidade de Hong Kong, todas as construções públicas são precedidas por um estudo de feng shui.

As organizações que atuam nesses países culminam por adotar a técnica em seus edifícios. É o que aconteceu com a British Airways, ao construir uma piscina no Hopewell Centre, de sua propriedade. Embora, na campanha veiculada pela empresa, anunciasse apenas o fato de existir uma piscina na cobertura, conforme Hobson (op.cit.) o objetivo foi tratar o prédio que, por ser redondo, se parecia com uma vela e corria o risco de se incendiar.

Outras organizações, como o Hilton Internacional, utilizam o feng shui em sua publicidade naquela região para atrair turistas chineses. Outras, ainda, como o Citibank, interessadas em atuar na Ásia, buscaram apoio de especialistas em feng shui quando lá se estabeleceram. Conforme assinala Minda (1995), corre perigo quem ignora o feng shui e espera ter pessoas chinesas como suas sócias, clientes ou até mesmo como empregadas.

As experiências com essa técnica são evidenciadas também em países desenvolvidos, como os Estados Unidos. Em reportagem sobre o assunto, Lynn (2001, p. 12) cita a entrevista que o empresário Donald J. Trump concedeu às revistas The Time e Fortune, revelando que aplicou os princípios do feng shui no Trump International Hotel and Tower. Para Trump, os asiáticos estão se tornando parte importante do mercado e grandes competidores. 
Sunoo (2000, p. 42), em outra reportagem, menciona que a consultora em feng shui Adele Trebil listou importantes empresas americanas para as quais trabalhou, dentre elas, a CBS Television Studios, em Los Angeles; Maxim Hotel/Cassino em Las Vegas, dentre outros.

Em outra reportagem editada pela The American City \& County, o empresário Mitch Lansdell faz um relato das mudanças que se processaram em sua empresa, quando optou por chamar um consultor em feng shui. Segundo este, a partir do momento em que realizou algumas mudanças no layout de seu escritório, passou a dirigir seu olhar para a direção nordeste, quando estava realizando negociação ao telefone, entre outras orientações da especialista, o déficit em sua empresa reduziu-se em US\$ 2 milhões, no prazo de dois anos.

O pensamento desse empresário, contudo, não é generalizado entre as empresas. Em entrevista concedida pelo vice-presidente da Coca-Cola, James Chestnut, este afirma que está utilizando apenas alguns dos princípios do feng shui no complexo industrial de Atlanta, como a remoção de vasos de plantas do escritório do presidente da empresa, conforme orientação de uma especialista, objetivando criar um espaço mais amplo. Entretanto, nem todas as sugestões foram acatadas. Cita como exemplo o fato de um prato de metal, que foi colocado na entrada do edifício, conforme sugestão, e retirado porque a empresa não gostou do visual.

Os textos evidenciam que o feng shui é uma arte e não uma ciência. Sua contribuição para as organizações, então, parece caminhar no sentido de organizar espaços, tornar agradáveis os ambientes e, desta forma, contribuir para a melhoria da performance dos empregados. Reportagem de Hendrickson (2000, p. 12) sobre a consultora Angi Ma Wong refuta a crítica ao feng shui de pessoas que alegam se tratar apenas de uma superstição. Para ela, a organização do ambiente faz as pessoas se sentirem mais calmas; faz com que trabalhem mais efetivamente e lhes propicia mais conforto. Um empregado feliz tem mais entusiasmo para trabalhar, torna-se mais produtivo e mais lucrativo para a empresa.

\subsubsection{Grafologia}

Mandruzato (1996, p. 1) define grafologia como o "estudo da estrutura psicológica do ser humano através da sua escrita”. A técnica começou a ser desenvolvida em 1622, pelo 
médico e professor italiano Camilo Baldo de Bologna; aperfeiçoada em 1871, pelo francês Abade Jean Hippolite Michon; e proposta como ciência em 1930, por Jean Jaques CrépieusJamin, aluno de Michon.

A técnica fundamenta-se no fato de que a escrita nasce no cérebro, é estimulada no palladium, caminha através dos neurônios e é apoiada pelos músculos. Isso faz com que o indivíduo projete, através da escrita, aspectos emocionais, psicológicos, fisiológicos e estéticos. Quando alfabetizado, na medida em que o indivíduo começa a escrever o símbolo, que são as letras, transfere para o papel também sua forma de ser e de agir, seus potenciais, frustrações, desejos e ambições, bem como a forma como age e reage rotineiramente.

O estudo consiste na análise de um texto escrito de "próprio punho", pela pessoa a ser avaliada. Cabe ao especialista avaliar a forma, o tamanho, a distribuição no papel, dentre outras características. Segundo Mandruzato (op.cit.) ainda que a caligrafia de uma pessoa seja semelhante à de outra, existem diferenças individuais que tendem a aumentar, na medida em que a pessoa analisada passa a escrever com mais espontaneidade.

É possível depreender dessa análise alguns aspectos comportamentais como, por exemplo, definir se o analisado é mais linfático/fleumático (letra levemente arredondada com inclinação suave e tamanho uniforme), bilioso/colérico (letra bem marcada e angulosa, sem floreios nem apêndices), nervoso (letra pequena, sinuosa e desigual, com pontos e barras irregulares e acentuadas) ou sanguíneo (letra grande e inclinada para a direita).

Por se tratar de uma técnica voltada para a análise da escrita, tem como ponto positivo o fato de não ser impregnada por questões como raça, cor, religião ou gênero. Além disso, é uma técnica de rápida ${ }^{10}$ e fácil aplicação ${ }^{11}$ e a análise independe da presença do avaliado.

De todas as técnicas consideradas alternativas, a que mais contém estudos é a grafologia. Trata-se de um trabalho que, embora ainda não aceito como instrumento pelo Conselho Federal de Psicologia, no caso brasileiro, é utilizado em empresas de porte, como é o caso do Grupo Pão de Açúcar (1. Simpósio de Ferramentas Avançadas em Gestão de Pessoas, 2003).

\footnotetext{
${ }^{10}$ Em torno de 30 a 40 minutos.

${ }^{11}$ É solicitado à pessoa a ser analisada, para que escreva um texto de 20 a 25 linhas e assine.
} 
Conforme Randall (1990, p. 81), uma pesquisa realizada em 1980, pela Prentice-Hall, com 2.500 empresas em seleção de pessoal para vendas, nos Estados Unidos, revelou que 64,5\% utilizavam algum tipo de teste para escolher as pessoas e a grafologia era um dos testes citados. Anderson (1986, p. 19) confirma a utilização da grafologia como um dos dez métodos encontrados em pesquisa realizada em dados dos anos 80. Outra pesquisa, realizada pela consultoria Deloitte Touche Tohmastu, em 2002, de 115 empresas pesquisadas, 42\% utilizavam a grafologia na seleção de pessoal e, de modo especial, para os cargos de nível médio.

Em artigo intitulado Graphology in business (1994, p.17), cita-se Lawrence Warner. Este acredita que em torno de 3\% das empresas inglesas utilizem essa técnica em seus processos de recrutamento e seleção, pois elas contribuem, segundo ele, para ampliar o conhecimento sobre o candidato. Hornsby (1992, p. 4) informa que, em 1988, duas mil empresas norteamericanas utilizaram a técnica para seleção de pessoal, objetivando detectar problemas vinculados à honestidade do candidato.

Alerta, contudo, que essa técnica, para ser confiável e válida, demanda cuidados especiais no que diz respeito à experiência e perícia do intérprete. Smith (1992, p. 4) informa que outras empresas utilizam-na também em processos de promoção e desenvolvimento de equipe.

Já Tixier (1996, p. 70), a partir dos dados de pesquisa que realizou em países da Europa, refere que a técnica é praticamente desconhecida no Reino Unido e, salvo a França, é tratada com cautela nos demais países, por não ter sido comprovada cientificamente. Nesse sentido, esta pode ser empregada para dirimir dúvidas sobre um candidato ou trazer clarificação complementar ao término do processo, mas jamais deve excluir outras avaliações.

Schuler et al apud Heraty (1998, p. 675), em outro estudo que buscava comparar técnicas utilizadas no recrutamento e seleção de sete países europeus, encontrou a grafologia como uma das utilizadas por empresas da França. No mesmo artigo, cita-se a pesquisa realizada por Cranet, sobre as práticas de seleção na Irlanda. Embora, em último lugar, a grafologia tenha sido uma das técnicas aplicadas ${ }^{12}$.

\footnotetext{
${ }^{12}$ De um total de 169 citações, 0,6\% das empresas aplicam todas as vezes, 0,6\% aplicam muitas vezes, $4 \%$ aplicam algumas vezes, $1 \%$ aplicam poucas vezes, $94 \%$ não aplicam.
} 
A utilização dessa técnica na França é um assunto controverso. Conforme Cerdin (2001, p. 221), é comum naquele país, empresas solicitarem uma carta de apresentação manuscrita e um curriculum vitae impresso e, segundo estimativa de King (1994, p. 26), membro do The British Institute of Graphologists, o percentual de utilização em recrutamento, entre os franceses, gira em torno de $75 \%$ a $80 \%$.

Steiner (1996, p. 143), por sua vez, após estudo realizado com estudantes, comparando as culturas de França e Estados Unidos, concluiu que a grafologia era mais favoravelmente percebida entre os franceses do que entre os norte-americanos, embora ressalte a existência de opiniões contrárias à técnica também entre os franceses. Para Cerdin (op.cit.) a utilização da Internet em processos de recrutamento pode diminuir o uso da grafologia, a menos que as organizações passem a solicitar amostras da letra.

Carvalho (2000, p. 81) informa que também na Alemanha a grafologia é amplamente difundida e aplicada na seleção de todos os níveis hierárquicos de candidatos a emprego, o que tem gerado grande polêmica quanto à viabilidade ou não dessa ferramenta como instrumento de seleção de pessoal.

Aspecto a ser ressaltado é que, tanto no Brasil como no exterior, esta técnica não é utilizada isoladamente e, sim, como suporte a outras técnicas, uma vez que estudos como os do Institute of Personnel Management (IPD) consideraram não conclusivas as evidências que validariam ou não a grafologia.

Bem-Shakhar (1986, p. 646) descreve dois estudos realizados, objetivando validar o uso da grafologia no desempenho do trabalho. No primeiro estudo, foram analisados textos manuscritos de israelitas e teve como resultado um pequeno percentual de validade. $\mathrm{O}$ mesmo teste foi analisado por não grafólogos, que utilizaram um modelo linear simples, e com resultado idêntico ao dos técnicos sem efeitos práticos..

Num segundo estudo, que buscava verificar a profissão de 40 homens que trabalhavam na mesma profissão, durante pelo menos dez anos, os dados obtidos por grafólogos não foram significativamente melhores do que o modelo de adivinhação. A conclusão do autor é que se trata de uma técnica sem efeitos práticos. 
Nesse sentido, Thomas (2001, p. 31) faz algumas considerações sobre a grafologia. Primeiro, concorda com o IPD acerca da inexistência de pesquisa que comprove a eficácia da técnica em seleção de pessoal: a confiabilidade é apenas moderada. Segundo, há pouca evidência sobre a exatidão desta técnica na predição de traços de personalidade. Terceiro, inexiste correlação direta absoluta entre a escrita com medidas de desempenho no trabalho.

Thomas (op.cit.) indaga então: "dado que existem poucas pesquisas que demonstrem a eficácia da grafologia, por que então muitas empresas insistem em utilizá-la?”. Embora sem uma resposta concreta, o autor sugere que pode ser fruto de coincidências de análise, ocorridas a partir de casos nos quais foram analisadas amostras de escrita sem que o objetivo fosse explicitado e que levaram à fé na técnica. Uma possibilidade mais remota, para ele, é a noção de a grafologia ser mais uma técnica do que uma ciência e, por essa razão, alguns grafólogos podem utilizar instrumentos distintos do método científico, como é o caso da intuição, e fazer predições mais exatas do que outros.

A dúvida levantada pelo autor segue a mesma linha deste projeto: se empresas utilizam tais técnicas, por quais razões o fazem?

\subsubsection{Florais}

A terapia floral integra o que se denomina de medicina vibracional e tem por objetivo o apoio aos processos de desenvolvimento individual e grupal, que, segundo Boog (1997, p. 55) “atua no ‘corpo emocional' visando equilíbrio, harmonia e saúde”.

Embora seja utilizada desde a antiguidade, pelos povos do Extremo Oriente, pelos indígenas nas Américas e pelos aborígines da Austrália, a forma pela qual é conhecida nas organizações data da década de 30, quando o médico inglês Dr. Edward Bach identificou 38 flores e, com elas, preparou essências, passando a usá-las no tratamento dos estados emocionais de seus pacientes. A essência floral possibilita que a dificuldade apresentada pela pessoa apareça e, dessa forma, esta tenha condição de vivenciá-la e superá-la.

A terapia floral, segundo Boog (op.cit), nas situações pessoais e organizacionais típicas, pode ser utilizada para combater problemas como liderança inadequada, indecisão, negatividade, 
medo, falta de flexibilidade, criatividade, estresse, crises, agitação excessiva, competição e cooperação, espírito de equipe, harmonia, comunicação, auto-expressão e visão mais ampla e percepção. A aplicação na empresa ocorre conforme Figura 6.

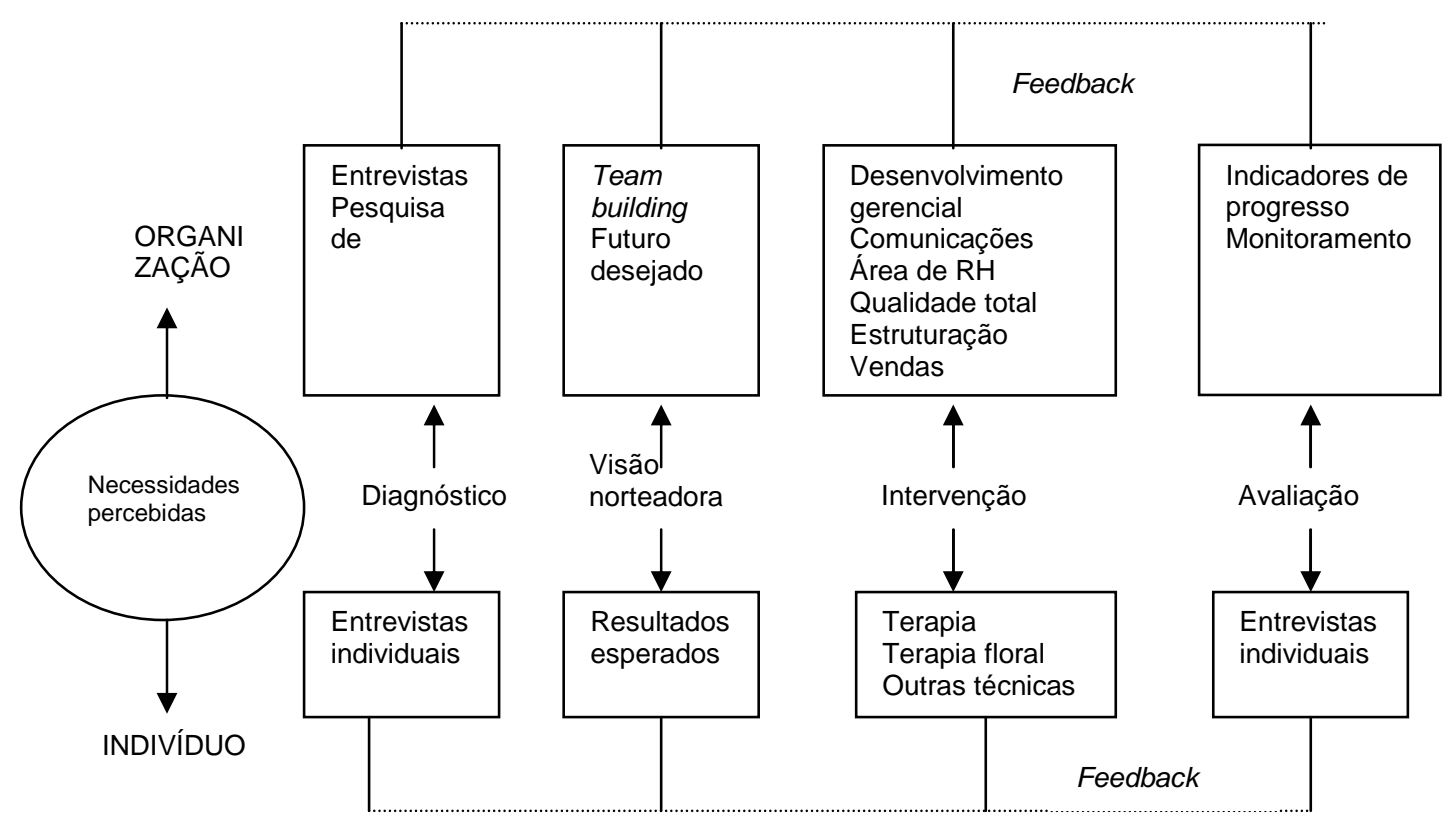

Fonte: BOOG, G.; BOOG, Magdalena T. Energize sua empresa.São Paulo: Gente, 1997.

Figura 6 - Aplicação de florais na empresa

\subsubsection{Musicoterapia}

Musicoterapia, segundo Benenzon (1988, p. 11):

\footnotetext{
"é o campo da medicina que estuda o complexo som-ser humano-som, para utilizar o movimento, o som e a música, com o objetivo de abrir canais de comunicação no ser humano, para produzir efeitos terapêuticos, psicoprofiláticos e de reabilitação no mesmo e na sociedade".
}

Trata-se de um processo que vem sendo utilizado como apoio, por exemplo, a pacientes vítimas de episódios traumáticos que dificultam sua comunicação com o mundo externo. Através da emissão de sons, o indivíduo pode comunicar um processo interno por meio de uma representação simbólica.

Esse tipo de comunicação pode ser empregado também nas organizações. Segundo Santiago (2002, p. 535), a música estimula a criação de um ambiente mais harmonioso no trabalho e, 
ainda, se adequadamente utilizada, permite melhorias, como maior rapidez e qualidade, além de estimular a aceitação quase imediata pelas pessoas.

Olivares e Santiago (1999, p. 344) sugerem que a música pode ser utilizada como ferramenta de apoio em treinamentos, escritórios, fábricas, salas de espera, bancos, dentre outros. Em casas comerciais, segundo o autor, a música cria uma atmosfera harmoniosa para os empregados e estimula clientes a realizarem compras com maior tranqüilidade.

Os autores citam experiência desenvolvida pelo Centro de Pesquisas e Aplicações Psicomusicais da França, que dividiu o efeito de determinadas músicas em cinco grandes grupos, que podem ser utilizadas em treinamento e desenvolvimento. São eles: músicas de efeito relaxante; músicas que promovem tranqüilidade profunda; músicas de efeito tonificante e euforizante; músicas que promovem efeito de exaltação e estimulação; músicas para diminuir a ansiedade e harmonizar; e, finalmente, músicas para acalmar ambientes tumultuados.

\subsubsection{Aromaterapia}

Segundo Spiri (2002, p. 595), aromaterapia é uma técnica que faz uso de "óleos essenciais $100 \%$ puros, de origem vegetal e completos", ou seja, não sofrem qualquer tipo de manipulação, utilização de produtos químicos ou sintéticos. Podem ser utilizados nas empresas em treinamentos, departamentos de vendas e em sistemas de ar condicionado, exalando aromas que, segundo a autora, a depender da essência, atua no corpo físico como analgésico, estimulante, sedativo, dentre outros efeitos.

Um estudo realizado por Puppim (2000, p. 65) em três empresas localizadas na cidade de Vitória, Espírito Santo, com a aplicação de óleos essenciais no ambiente de trabalho, obteve em duas semanas, resultados positivos no tocante a redução para 0-\% das queixas insônia e irritação das pessoas que se submeteram à experiência. No início da pesquisa, as queixas para insônia eram de 15\% na empresa Autovil,, 12\% Cobravi, e 40\% na Polícia TécnicoCientífica irritação eram de $10 \%, 12 \%$ e $40-\%$ respectivamente. 


\subsubsection{Radiestesia}

A radiestesia não constava do escopo de ferramentas alternativas a serem analisadas. Contudo, durante a pesquisa de campo, esta ferramenta foi mencionada por alguns especialistas e, posteriormente, em algumas das empresas pesquisadas. Por esta razão, buscou-se referencial teórico sobre o assunto, que apoiasse sua análise.

Radiestesia é uma ferramenta que, conforme Tomlinso (1993, p. 47), estuda a detecção das radiações do corpo humano, sem a ajuda de instrumentos científicos, que ele denomina de mais ortodoxos. Segundo o autor, trata-se de um processo de adivinhação, capaz de identificar lençóis de água, petróleo e minerais existentes em um determinado ponto do solo, com o auxílio de uma varinha de madeira (forquilha).

Outro instrumento utilizado na radiestesia é o pêndulo: uma bolinha de madeira ou outro material (alguns utilizam o cristal) que é suspensa por um fio preso entre o indicador e o polegar. O especialista formula uma pergunta e obtém como resposta Sim ou Não.

É uma ferramenta rudimentar, já utilizada na antiguidade, e está relacionada ao uso da intuição e do poder da mente. Não se encontrou pesquisa que evidencie algum resultado que comprove a efetividade desse instrumento.

\subsubsection{Shiatsu}

Shiatsu é uma ferramenta que utiliza os polegares, os dedos e a palma das mãos para pressionar a pele, mediante estímulos rítmicos e modulares, de forma a melhorar o funcionamento interno do corpo, manter a saúde e tratar de doenças específicas. (Masunaga, p. 1977)

A técnica procura corrigir e manter a estrutura óssea, juntas, tendões, músculos e linhas meridianas que, quando funcionam de maneira precária, levam a pessoa a contrair doenças.

No shiatsu, o diagnóstico do paciente é realizado através do toque na pele. Uma dessas partes é o pulso. Segundo o autor (op.cit), enquanto na medicina ocidental o pulso indica palpitações cardíacas; na medicina oriental revela as condições dos 12 meridianos, ou 
canais de energia vital do corpo. A técnica consiste em sessões de massagem nos pontos do corpo que devem ser tratados.

Nas organizações, o shiatsu pode ser utilizado, em saúde ocupacional, como tratamento complementar ou, ainda, em programas de melhoria da qualidade de vida no trabalho. 


\subsection{Síntese do referencial teórico utilizado}

O referencial teórico proposto para este estudo pode ser sintetizado, conforme Quadro 6.

\begin{tabular}{|c|c|c|c|c|c|c|}
\hline \multicolumn{7}{|c|}{ Quadro 6 - Síntese do referencial teórico utilizado } \\
\hline $\begin{array}{l}\text { Práticas } \\
\text { tradicionais em } \\
\text { gestão de } \\
\text { pessoas }\end{array}$ & $\begin{array}{l}\text { Práticas } \\
\text { alternativas em } \\
\text { outras áreas do } \\
\text { conhecimento }\end{array}$ & Dimensão psíquica & $\begin{array}{l}\text { Dimensão } \\
\text { sociológica }\end{array}$ & Dimensão holística & $\begin{array}{l}\text { Dimensão da } \\
\text { administração }\end{array}$ & $\begin{array}{c}\text { Práticas } \\
\text { alternativas }\end{array}$ \\
\hline \multirow[t]{3}{*}{$\begin{array}{l}\text { Testes } \\
\text { psicológicos. } \\
\text { Monitoração do } \\
\text { clima } \\
\text { organizacional. } \\
\text { Avaliação de } \\
\text { desempenho. }\end{array}$} & \multirow[t]{3}{*}{$\begin{array}{l}\text { Experiências } \\
\text { recentes } \\
\text { evidenciam a } \\
\text { utilização de } \\
\text { ferramentas } \\
\text { alternativas em } \\
\text { outras áreas do } \\
\text { conhecimento. }\end{array}$} & $\begin{array}{l}\text { Psicodinâmica } \\
\text { organizacional: a } \\
\text { organização e a divisão } \\
\text { do trabalho e sua relação } \\
\text { com o conteúdo } \\
\text { ergonômico da tarefa. A } \\
\text { busca pelo desejo e a } \\
\text { motivação no trabalho. }\end{array}$ & $\begin{array}{l}\text { Os embates } \\
\text { entre a visão } \\
\text { antropológica e } \\
\text { sociológica } \\
\text { sobre cultura e } \\
\text { ideologia. }\end{array}$ & $\begin{array}{l}\text { Natureza, } \\
\text { sociedade e o } \\
\text { homem em uma } \\
\text { perspectiva } \\
\text { integral. }\end{array}$ & $\begin{array}{l}\text { A gestão de } \\
\text { pessoas em } \\
\text { uma nova } \\
\text { modelagem. }\end{array}$ & \multirow{3}{*}{$\begin{array}{l}\text { Descrição do uso } \\
\text { das ferramentas } \\
\text { no ambiente } \\
\text { organizacional: } \\
\text { Astrologia, } \\
\text { Numerologia, } \\
\text { Feng shui, } \\
\text { Grafologia, } \\
\text { Florais, } \\
\text { Musicoterapia, } \\
\text { Aromaterapia, } \\
\text { Radiestesia, } \\
\text { Shiatsu. }\end{array}$} \\
\hline & & $\begin{array}{l}\text { Psicologia analítica: } \\
\text { Sincronicidade, o } \\
\text { inconsciente coletivo e } \\
\text { seus arquétipos e o } \\
\text { processo de individuação } \\
\text { no contexto } \\
\text { organizacional. }\end{array}$ & $\begin{array}{l}\text { A análise da } \\
\text { diversidade e da } \\
\text { cultura } \\
\text { organizacional. }\end{array}$ & $\begin{array}{l}\text { A } \\
\text { espiritualidade } \\
\text { no trabalho. }\end{array}$ & $\begin{array}{l}\text { Melhoria na } \\
\text { qualidade de } \\
\text { vida no } \\
\text { trabalho como } \\
\text { uma } \\
\text { possibilidade. }\end{array}$ & \\
\hline & & \multicolumn{4}{|c|}{ Possíveis lacunas nas dimensões que podem ou não ser ocupadas por ferramentas alternativas. } & \\
\hline
\end{tabular}




\section{METODOLOGIA}

\subsection{A importância do modelo metodológico}

Caminhar do senso comum em busca de evidência científica não é uma tarefa fácil, principalmente quando envolve práticas que, ao longo do tempo, embora de conhecimento público, têm sido entendidas como "ocultas" ou metafísicas. Por essa razão, torna-se mister e premente o uso de ferramental metodológico que mantenha sob controle os aspectos relacionados a crenças e valores sobre temas dessa natureza.

Este capítulo apresenta os referenciais metodológicos através dos quais a pesquisa foi desenvolvida. Método científico é, segundo Nogueira (1975, p. 74) uma sucessão de passos através dos quais são identificadas novas relações entre fenômenos que interessam a um determinado ramo da ciência (no caso deste estudo, a administração de empresas) ou, ainda, a aspectos que ainda não foram analisados de um determinado fenômeno.

A tese de doutoramento segundo Severino (1986, p. 192) é o tipo mais representativo de trabalho científico monográfico e, como tal, deve contemplar a pesquisa de um único tema delimitado e restrito, fruto de pesquisa que pode ser teórica, documental, experimental, histórica ou filosófica.

No que concerne aos objetivos, Selltiz et al (1965, p.59) enumera quatro grandes grupamentos nos quais estes podem estar contemplados. São objetivos:

1. Onde se pretende obter maior compreensão ou familiaridade, o que permitirá a melhor formulação de um problema de pesquisa ou a criação de novas hipóteses. É chamado de estudo exploratório ou formulador e está pautado na descoberta de idéias e de intuições, razão pela qual necessita de maior flexibilidade. 
2. Que apresentam as características de uma situação, grupo ou indivíduo específico. Este grupo e o que vem a seguir constituem-se de estudos descritivos e supõem exatidão.

3. Que buscam verificar com que freqüência um determinado acontecimento ocorre ou com o que este pode estar relacionado.

4. Que verificam uma hipótese relacional entre variáveis: são aqueles estudos causais, que supõem além da precisão também a perspectiva de inferências causais.

Este estudo é do tipo exploratório, uma vez que pretende pesquisar um tema pouco pesquisado, no âmbito da administração de empresas. De acordo com Gil (1999, p. 121), esta abordagem é a que apresenta menor rigidez na etapa de planejamento. Cervo (2003, p. 69) considera-a como um tipo quase ou não científico. Em geral, compreende a utilização de instrumentos de coleta de dados, como levantamento bibliográfico e documental, entrevistas não estruturadas e estudo de caso.

O objetivo deste tipo de estudo é ampliar o conhecimento de um fato pouco explorado, razão pela qual se torna difícil formular hipóteses que sejam precisas e em condições de ser operacionalizadas. Além disso, o planejamento deve ser flexível o bastante para incorporar vários aspectos do problema a ser analisado. O produto final culmina por tornar-se um problema com maior nível de esclarecimento, que pode ser mais bem investigado, por meio de procedimentos mais sistematizados.

\subsection{A pesquisa qualitativa}

Embora o estudo tenha procurado levantar dados quantitativos e qualitativos, como descrito no item 3.3, a ausência de dados numéricos que permitisse chegar a conclusões com validade estatística e o tipo de problema de pesquisa que se está analisando, mostrou a necessidade de privilegiar os dados qualitativos. Tal escolha é compreendida de forma mais clara, quando se retoma as suas origens. A pesquisa qualitativa começou a ser utilizada nas ciências sociais como uma reação ao modelo positivista, criado por Augusto Comte. Este pensador 
estabeleceu uma hierarquia de dependência entre as ciências: a matemática ocupava o primeiro lugar, seguido da astronomia, física, química, biologia e, em ultimo lugar, a sociologia.

A superioridade das ciências naturais sobre as ciências sociais, segundo Goldemberg (1997, p.18), era criticada já no século XIX. O filósofo alemão Wilhelm Dilthey, foi um dos primeiros a se posicionar: para ele, enquanto as ciências naturais buscam generalizar e descobrir regularidades, as ciências sociais procuram uma compreensão interpretativa acerca das vivências das pessoas no contexto em que tais experiências acontecem. A partir dessa época. a aceitação da pesquisa qualitativa foi crescendo nos meios acadêmicos, de forma que, atualmente, ela divide com a pesquisa quantitativa a preferência dos pesquisadores.

Minayo et al (1994, p. 21) considera que a pesquisa qualitativa trabalha com um "universo de significados, motivos, aspirações, crenças, valores e atitudes" que não podem ser quantificados, pois não são reduzidos à operacionalização de variáveis. Para estes autores a diferença entre a pesquisa quantitativa e a qualitativa é de natureza, mas acreditam que elas são complementares: enquanto a primeira apreende fenômenos restritos à região "visível, ecológica, morfológica e concreta", a segunda, aprofunda sua análise nas ações e relações humanas, que não são perceptíveis e captáveis por estatística.

Segundo Richardson et al (1999, p.80), a pesquisa qualitativa é requerida em, pelo menos, três situações:

1. Quando se deseja conhecer fatos do passado ou estudar grupos dos quais se tem pouca informação.

2. Quando se pretende compreender aspectos psicológicos complexos, tais como análise de atitudes, motivações, expectativas, valores, dentre outros.

3. Quando se procura analisar os indicadores de funcionamento de estruturas sociais. Neste caso, a concepção teórica escolhida imprimirá variação à escolha metodológica.

O método, ou pesquisa qualitativa, segundo Roesch (1999, p. 154), é adequado a uma fase exploratória da pesquisa. 
No que concerne ao caminho percorrido para a execução da pesquisa, Minayo et al (op.cit., p.26) descreve como um ciclo que se inicia com a definição de um problema ou pergunta. A seguir, passa-se à fase exploratória, cujo foco é a construção do projeto de investigação e, posteriormente, ao trabalho de campo, de caráter relacional e prático, que confirmará ou refutará a hipótese previamente formulada. A última etapa, consiste no tratamento do material recolhido em campo, que será ordenado, classificado e analisado. O resultado deste trabalho é uma nova teorização ou reformulação de teorias já existentes.

\subsection{Fases da pesquisa e plano amostral}

A pesquisa, que possibilitou este estudo, foi desenvolvida conforme segue:

1. Levantamento de dados secundários tais como publicações, sites da Internet, dentre outros, que possibilitaram elaborar o referencial teórico e mapear a maior parte das ferramentas consideradas alternativas e sua aplicação no âmbito empresarial. A pesquisa de campo alterou esse mapeamento, acrescentando algumas ferramentas e agrupando outras que eram usadas como apoio e não a prática propriamente dita.

2. Levantamento de dados primários em empresas e com consultores que utilizam uma ou mais práticas alternativas, visando obter autorização para a realização de estudos de caso. Para obter esses dados, foi necessário alterar a estratégia inicialmente formulada que, na prática, se revelou insuficiente para a concretização deste estudo. Os dados foram colhidos a partir do seguinte caminho:

a) Envio de e-mails para empresas brasileiras de grande porte, divulgadas pela revista Exame (2004), na edição Melhores e Maiores, objetivando realizar uma primeira aproximação com essas organizações, bem como identificar aquelas que utilizavam pelo menos uma das práticas alternativas a serem analisadas para, a seguir, encaminhar uma pesquisa formal (Anexo 1).

Definiu-se como população a ser pesquisada os dirigentes que atuaram na gestão de pessoas de empresas brasileiras de grande porte e os especialistas/consultores que prestavam serviços 
de gestão pessoal das empresas, utilizando algum tipo de ferramenta alternativa. Os critérios utilizados pela revista para avaliar o tamanho e o sucesso da empresa (op.cit.:49) foram: crescimento das vendas; investimento - no imobilizado; liderança de mercado; liquidez corrente; riqueza criada por empregado; rentabilidade do patrimônio; e um bônus que a revista concede àquelas que se destacaram em cidadania corporativa e como as melhores empresas para se trabalhar. A escolha dessas empresas para amostra, dentro do universo de empresas do País, ocorreu pelo fato de que, em virtude de seu porte, de modo geral, supunha-se a existência de uma área formal em sua estrutura, dedicada à gestão de pessoas, que é o foco deste estudo.

b) Para a realização da segunda etapa da pesquisa, elaborou-se um questionário (Anexo 2) contendo questões dicotômicas e de múltipla escolha, que foi submetido a um pré-teste com gerentes de três empresas, sendo acrescido de uma questão, relativa aos motivos pelos quais a organização não utiliza algum tipo de ferramenta alternativa e enviada a empresas selecionadas na amostra, por meio de correio eletrônico. O questionário foi encaminhado através de correio para as cem melhores empresas para trabalhar e enviar currículo, constantes na relação do site Sol Brilhando ${ }^{13}$.

O levantamento teve por objetivo, ainda, identificar as empresas que utilizam algum tipo de ferramenta alternativa, que seriam convidadas a participar das fases subseqüentes do estudo, juntamente com as empresas identificadas no item anterior.

No capítulo relativo à pesquisa de campo, ficou demonstrado que está fase foi prejudicada pela dificuldade de contato com as empresas e/ou a ausência de resposta aos e-mails e às correspondências encaminhados.

c) A segunda população constituiu-se de levantamento com especialistas que prestam serviços a empresas e, para isso, utilizam algum tipo de prática alternativa. Foram realizados:

\footnotetext{
${ }^{13}$ Disponível em: http://www.solbrilhando.com.br/ Empregos/melhores Empresas. Acesso em: 16 out.2004.
} 
c.1) Contatos com grupos de profissionais de empresas, dentre eles, o grupo $\mathrm{T}+\mathrm{D}^{14}$, composto pelo núcleo de $T \& \mathrm{D}^{15}$, anteriormente ligado à Associação Paulista de Administração de Recursos Humanos (APARH), que atuam em gestão de pessoas e se reúnem periodicamente, para discutir temas relativos a essa área. Alguns deles apoiaram o desenvolvimento deste estudo, através da indicação de especialistas que prestam serviços à organizações.

c.2) Levantamento de nomes de especialistas e/ou consultores, que divulgam seu trabalho por meio de publicações, sites da Internet ou em congressos e eventos no Estado de São Paulo. Foi-lhes solicitado que respondessem ao questionário mediante $e$-mail (Anexo 3).

O objetivo desse levantamento foi identificar:

a) Profissionais que já utilizaram, de fato, ferramentas alternativas nas organizações, quando atuaram como prestadores de serviços, para que participassem da última etapa da pesquisa, e

b) Obter indicação de empresas, para os quais estes prestam ou prestaram serviços, utilizando algum tipo de prática alternativa, que possibilitasse um contato e a realização de estudo de caso.

3. Na terceira fase da pesquisa, foi utilizado o método qualitativo, através do estudo de multicasos. O estudo de caso é a análise intensiva sobre uma só pessoa, grupo, organização, no qual todos os aspectos são investigados. Sua função, segundo Fachin (2001, p. 42), é explicar de forma sistemática fatos que ocorrem e podem estar relacionados às diversas variáveis. Dependendo da profundidade, surgem relações que não poderiam ser descobertas por outros meios. Roesch (1999, p. 197) entende que o estudo de um ou mais casos têm como estratégias de pesquisa:

- A análise de fenômenos em profundidade dentro de seu contexto e não traços, opiniões ou ações de pessoas, como ocorre em um survey.

\footnotetext{
${ }^{14}$ Treinamento + Desenvolvimento.

${ }^{15}$ Treinamento e Desenvolvimento.
} 
- A análise de processos sociais à medida que eles acontecem nas organizações. É possível, por meio dele, realizar análises processuais, contextuais e longitudinais.

Os principais instrumentos para coleta de dados foram, respectivamente, a entrevista semiestruturada e em profundidade e a análise de dados documentais. Nogueira (op.cit., p. 111) conceitua entrevista como um interrogatório direto que o pesquisador faz ao informante ou pesquisado, durante uma conversa face a face. Para Goode (1977, p. 240), é um processo de interação social. Não é, pois, uma simples conversa e sim uma pseudoconversa e, embora tenha implícita a necessidade de rapport, deve ser conduzida com clareza e orientação da pesquisa científica.

Quanto ao conjunto de níveis de análise, este estudo definiu como categorias-chave: abordagem na gestão de pessoas e utilização de ferramentas alternativas. Atenção especial foi destinada para as áreas de qualidade de vida no trabalho e seleção de pessoal em que se considerava, por hipótese, que essas ferramentas estariam sendo mais utilizadas.

O projeto previa a seleção de empresas, localizadas preferencialmente nas cidades de São Paulo e da região do $\mathrm{ABCD}$. Caso o levantamento não apontasse a existência de empresas que utilizassem essas práticas naquelas localidades, a pesquisa se estenderia para outras cidades e/ou estados do Brasil, o que de fato ocorreu. Foram pesquisadas 11 empresas, de 13 contatadas, localizadas nos Estados de São Paulo e Rio de Janeiro. O estudo foi realizado a partir de entrevista com o dirigente, responsável pela área de gestão de pessoas da organização (Anexo 5). Paralelamente, foram entrevistados especialistas em cada uma das ferramentas analisadas (Anexo 4),

No caso das empresas, a entrevista foi desenvolvida de forma a identificar as razões pelas se optou pela adoção de práticas alternativas na gestão de pessoas, a forma de utilização das ferramentas e seus resultados e a opinião do entrevistado sobre essas práticas.

Quanto aos especialistas, a entrevista foi pautada no conteúdo da ferramenta e na busca de dados que contribuíssem para identificar os resultados obtidos nas empresas para as quais eles prestaram serviços. 
A análise dos dados foi composta de forma a permitir uma comparação entre a visão dos entrevistados nas empresas, os especialistas nas ferramentas e os fatos apresentados que identificassem a real utilização ou não dessas ferramentas nas organizações e, se possível, os resultados.

O caminho percorrido neste estudo está desenhado conforme Figura 7. 


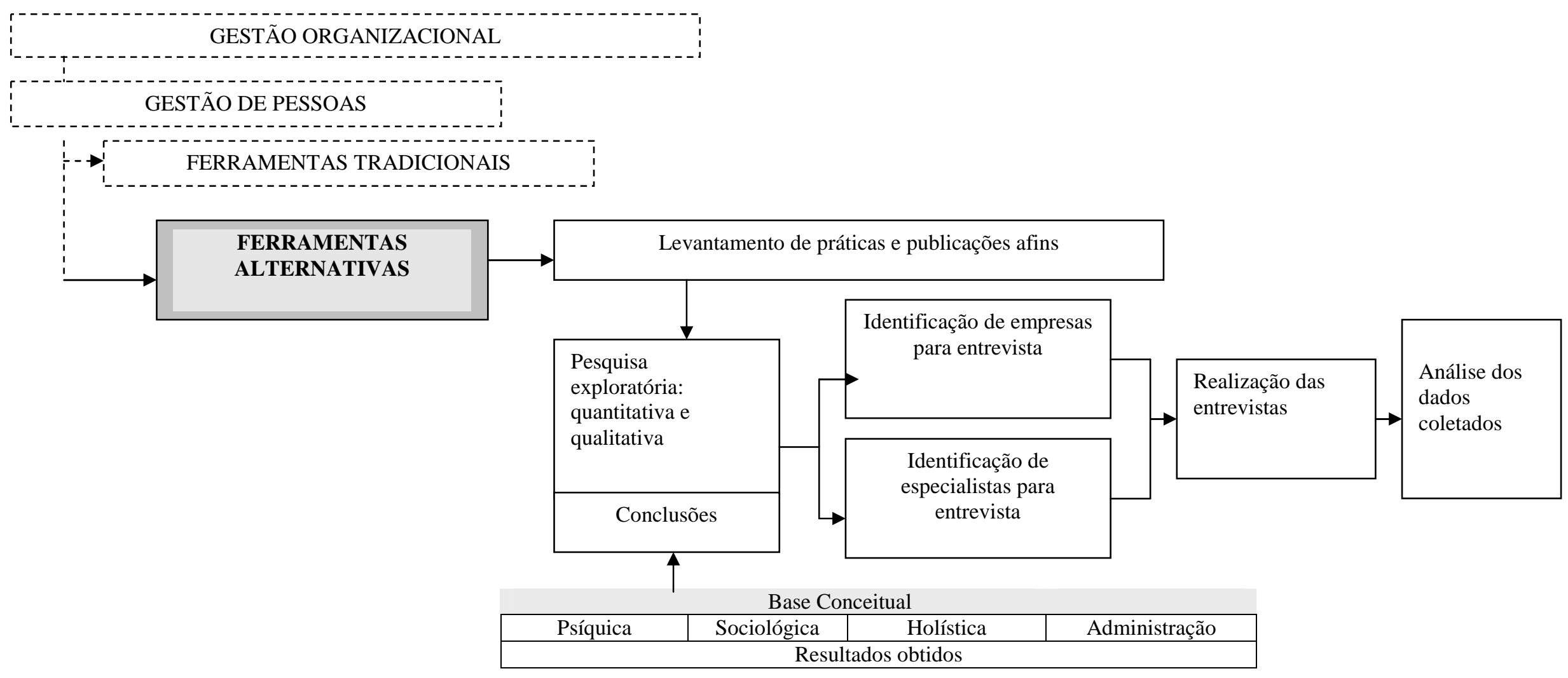

Figura 7 - Desenho do problema e metodologia proposta 


\subsection{Taxinomia Proposta}

Pretendeu-se, como contribuição deste trabalho, desenvolver uma tipologia que permita delinear qual tipo de organização tem maior tendência a aceitar e fazer uso de ferramentas alternativas, na sua gestão de pessoas. O conceito de tipo ideal foi utilizado por Weber (1981), ao construir um modelo que objetivava servir de parâmetro para os casos concretos.

Conforme salienta Lakatos (2000, p. 94), o tipo ideal é uma abstração e não uma descrição da realidade ou um "termo médio", pois não é fruto de uma média de casos concretos. "O tipo ideal expressa os aspectos significativos de uma dada realidade, que são suas características mais gerais, encontradas mais regularmente no fenômeno sob estudo."

A tipologia aqui proposta caracteriza as organizações, com relação à disposição para o alternativo, conforme Quadro 7.

Quadro 7 - Tipologia proposta

\begin{tabular}{|c|l|l|}
\hline "A" & $\begin{array}{l}\text { EMPRESAS } \\
\text { FRANCAMENTE } \\
\text { ALTERNATIVAS }\end{array}$ & $\begin{array}{l}\text { Utilizam ferramentas alternativas em processos de gestão de } \\
\text { pessoas e mostram-se receptivas a utilizar outras ferramentas. }\end{array}$ \\
\hline \multirow{2}{*}{ "F" } & $\begin{array}{l}\text { EMPRESAS } \\
\text { FRACAMENTE } \\
\text { ALTERNATIVAS }\end{array}$ & $\begin{array}{l}\text { Utilizam apenas um tipo de ferramenta alternativa e } \\
\text { mostram-se pouco receptivas a novas práticas. }\end{array}$ \\
\hline & $\begin{array}{l}\text { EMPRESAS } \\
\text { FRANCAMENTE } \\
\text { TRADICIONAIS }\end{array}$ & $\begin{array}{l}\text { Não utilizam ferramentas alternativas e mostram-se reativas à } \\
\text { possibilidade de vir a utilizá-las. }\end{array}$ \\
\hline
\end{tabular}




\section{PESQUISA DE CAMPO E ANÁLISE DOS DADOS}

A pesquisa de campo foi desenvolvida da seguinte forma:

1. Envio de e-mails para 93 empresas brasileiras de grande porte, constantes da revista Exame (2004), para identificar aquelas que utilizavam uma ou mais práticas alternativas e obter autorização para a realização de estudo de caso.

O resultado foi pouco promissor para os objetivos propostos neste estudo, pois, dos e-mails enviados, 34 não chegaram ao destino por falhas no sistema (Internet) e 19 empresas responderam. Destas, apenas a grafologia foi citada, conforme Gráfico 1.

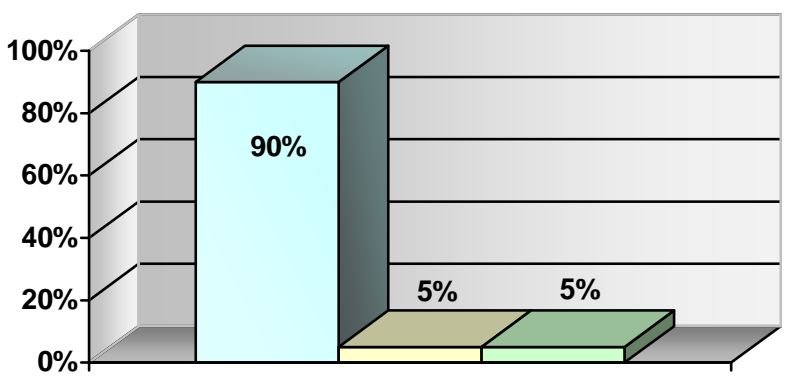

\begin{tabular}{|l|}
$\square$ Não utiliza alguma prática \\
alternativa \\
$\square$ Utiliza grafologia \\
$\begin{array}{l}\text { Informa somente os dados do } \\
\text { site }\end{array}$ \\
\hline
\end{tabular}

\section{Gráfico 1 - Utilização de práticas alternativas (e-mails)}

2. Envio de questionário, por meio de correio, para 95 grandes empresas, constantes da relação do site Sol Brilhando, eleitas como as melhores para se trabalhar e enviar currículo. Dentro de cada correspondência, foi encaminhado um envelope já selado para remessa da resposta. Dessa relação, cinco envelopes foram devolvidos por mudança de endereço e 17 empresas, ou seja, $18 \%$ responderam ao questionário. Destas, uma empresa está localizada na cidade de São Paulo. O gestor foi receptivo à pesquisa e foi entrevistado ${ }^{16}$. Das empresas que

\footnotetext{
${ }^{16}$ Empresa 2.
} 
responderam ao questionário, $41 \%$ referem já ter utilizado uma ou mais práticas alternativas (Gráfico 2).

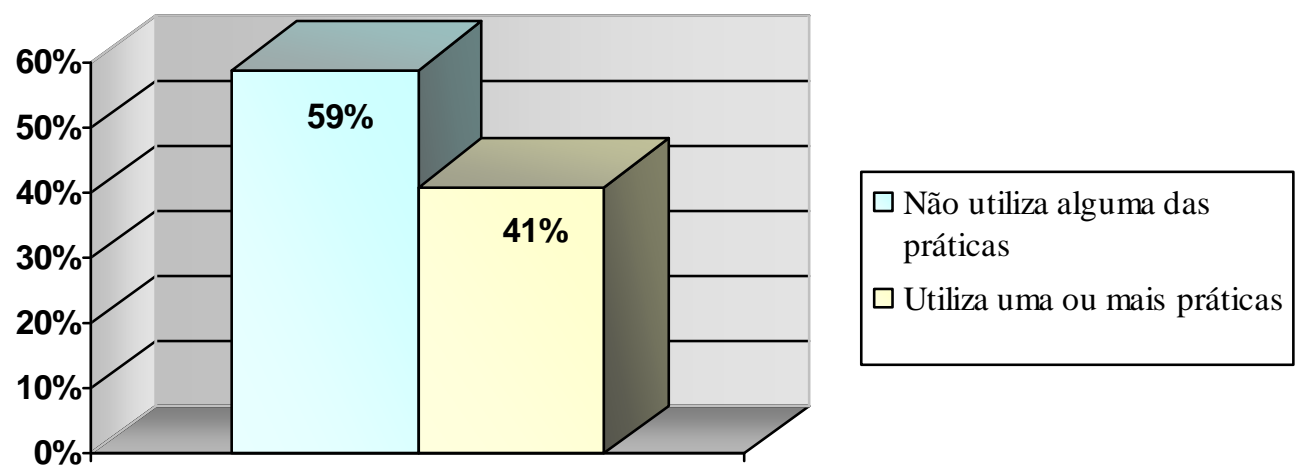

Gráfico 2 - Utilização de práticas alternativas (cartas)

Quanto ao perfil dos respondentes, constituiu-se de profissionais que atuam na área de $\mathrm{RH}$, sendo a maior parte de especialistas (analistas, assistentes) e dos escalões de supervisão e média gerência. Apenas 13\% exerciam cargos de direção superior (Gráfico 3).

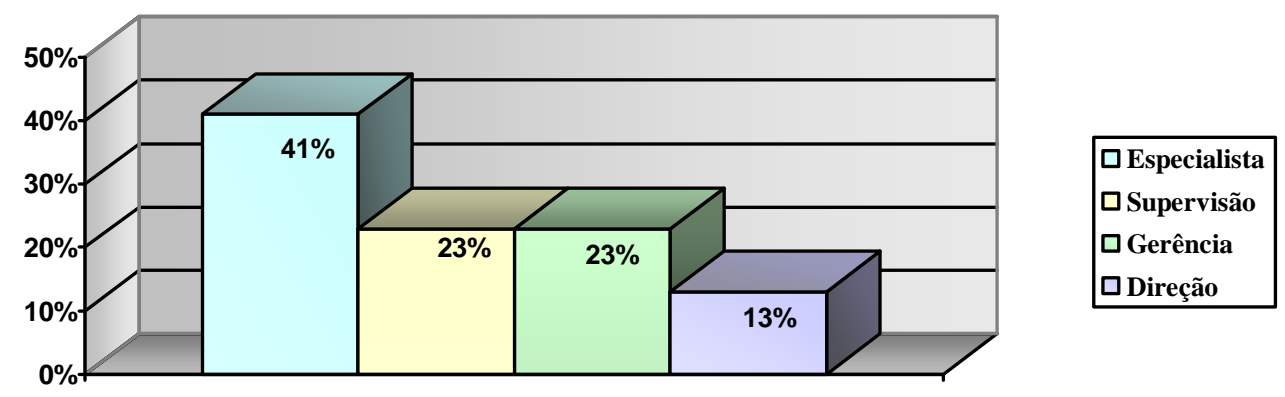

Gráfico 3 - Nível hierárquico dos respondentes

As empresas pesquisadas estavam distribuídas em termos de número de empregados, embora deva-se ressaltar que a maior parte tivesse mais de 500 empregados (Gráfico 4). 


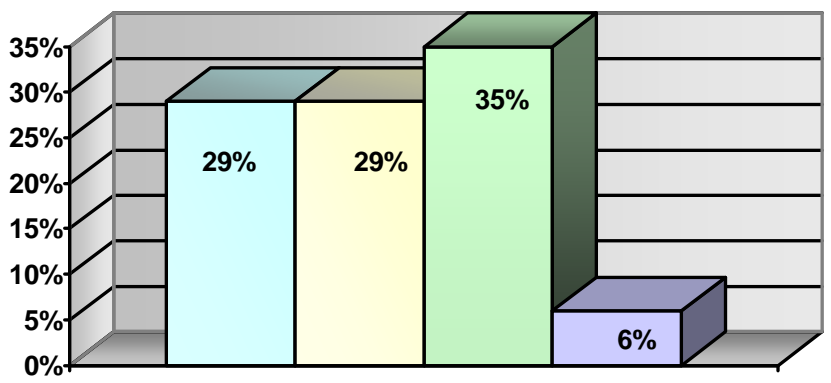

$\square$ Até 500

$\square$ De 501 a 1000

$\square$ De 1001 a 5000

$\square$ Acima de 5000

Gráfico 4 - Percentual de empregados por empresa

A pesquisa revelou também, neste grupo de empresas, que a única prática alternativa adotada rotineiramente é a grafologia. As demais foram citadas como tendo sido empregadas uma ou algumas vezes (Tabela 1 ).

Tabela 1- Freqüência das práticas utilizadas

\begin{tabular}{|c|c|c|c|c|c|}
\hline $\begin{array}{l}\text { Prática } \\
\text { alternativa }\end{array}$ & $\begin{array}{l}\text { Nunca } \\
\text { utilizou }\end{array}$ & $\begin{array}{l}\text { Utilizou apenas } \\
\text { uma vez }\end{array}$ & $\begin{array}{l}\text { Utilizou } \\
\text { algumas vezes }\end{array}$ & $\begin{array}{l}\text { Utiliza } \\
\text { rotineiramente }\end{array}$ & $\begin{array}{l}\text { Não sabe } \\
\text { responder }\end{array}$ \\
\hline Aromaterapia & 17 & & & & \\
\hline Astrologia & 17 & & & & \\
\hline Eneagrama & 16 & 1 & & & \\
\hline Essências florais & 16 & & 1 & & \\
\hline Feng Shui & 17 & & & & \\
\hline Grafologia & 8 & 2 & 2 & 4 & 1 \\
\hline Massoterapia & 16 & 1 & & & \\
\hline Musicoterapia & 15 & & 2 & & \\
\hline Numerologia & 16 & & 1 & & \\
\hline Radiestesia & 17 & & & & \\
\hline
\end{tabular}

As empresas que informaram não utilizar qualquer tipo de prática alternativa justificaram que as ferramentas tradicionais suprem suas necessidades (Tabela 2). 
Tabela 2 - Razões para a não utilização de práticas alternativas

\begin{tabular}{|l|c|c|}
\hline \multicolumn{1}{|c|}{ Justificativa } & Número de empresas & Percentual \\
\hline As ferramentas tradicionais suprem as necessidades & 7 & 70 \\
\hline Ausência de informação sobre a contribuição dessas práticas & 2 & 20 \\
\hline A empresa oferece outras alternativas em QVT & 1 & 10 \\
\hline
\end{tabular}

3. Pesquisa com um grupo do qual esta pesquisadora participa, denominado ConfrariaRH, composto por profissionais de Recursos Humanos de empresas de pequeno, médio e grande portes, que trocam informações através da Internet ${ }^{17}$. Foi encaminhado questionário ao moderador do grupo que o repassou aos demais membros.

Foram obtidas 18 respostas; a maior parte indicando que não utiliza qualquer tipo de prática alternativa (Gráfico 5).

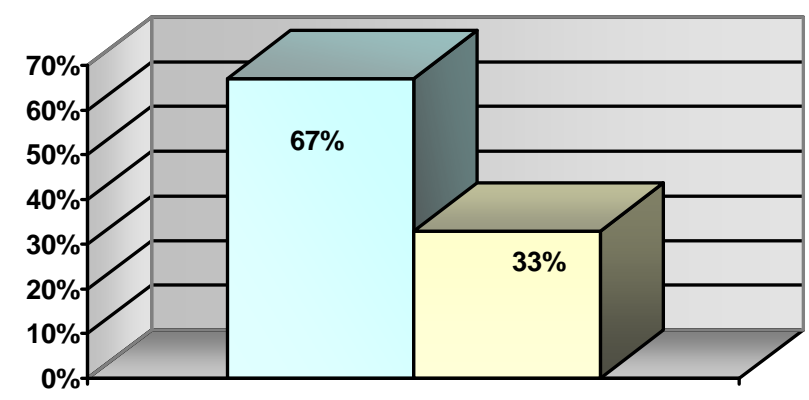

\begin{tabular}{|l|}
\hline Utiliza uma ou mais práticas \\
alternativas \\
$\square$ Não utiliza
\end{tabular}

Gráfico 5 - Utilização de práticas alternativas (ConfrariaRH)

Das empresas que acenaram positivamente, novamente se constata a preponderância da grafologia, conforme Tabela 3.

\footnotetext{
${ }^{17}$ www.confrariarh.com.br
} 
Tabela 3 - Perfil das empresas e freqüência de utilização

\begin{tabular}{|l|c|l|l|l|l|l|}
\hline \multirow{2}{*}{$\begin{array}{l}\text { Setor de } \\
\text { atividade }\end{array}$} & \multirow{2}{*}{$\begin{array}{l}\text { Número de } \\
\text { empregados }\end{array}$} & \multicolumn{2}{|c|}{ Grafologia } & Astrologia & $\begin{array}{l}\text { Essências } \\
\text { florais }\end{array}$ & Aromaterapia \\
\cline { 3 - 7 } & & $\begin{array}{l}\text { Utiliza } \\
\text { rotineiramente }\end{array}$ & $\begin{array}{l}\text { Utilizou } \\
\text { algumas } \\
\text { vezes }\end{array}$ & $\begin{array}{l}\text { Utilizou } \\
\text { uma vez }\end{array}$ & $\begin{array}{l}\text { Utiliza } \\
\text { rotineiramente }\end{array}$ & $\begin{array}{l}\text { Utiliza } \\
\text { rotineiramente }\end{array}$ \\
\hline Metalúrgico & 37 & & 1 & & & \\
\hline Telecomunicações & 167 & & 1 & 1 & & \\
\hline Farmacêutico & 222 & 1 & & & & \\
\hline $\begin{array}{l}\text { Tecnologia em } \\
\text { telecomunicações }\end{array}$ & 220 & 1 & & & & \\
\hline $\begin{array}{l}\text { Tecnologia em } \\
\text { recursos humanos }\end{array}$ & 400 & 1 & & & & \\
\hline $\begin{array}{l}\text { Embalagens } \\
\text { flexíveis }\end{array}$ & 604 & 1 & & & & \\
\hline
\end{tabular}

Duas das empresas pesquisadas foram contatadas por telefone. Em uma delas (tecnologia em $\mathrm{RH})$, o respondente não se dispôs a ser entrevistado, por estar se ausentando por período prolongado. Na empresa de embalagens flexíveis ${ }^{18}$, o respondente aceitou ser entrevistado.

4. Contato, mediante e-mail, com cinco empresas que prestam serviços em recrutamento e seleção para organizações. A única empresa que respondeu, informou que utiliza as ferramentas tradicionais e, somente quando solicitada pelo cliente, incorpora a grafologia como forma complementar em laudos que emite rotineiramente.

5. Os resultados obtidos no levantamento quantitativo nas áreas de recursos humanos das empresas, conforme demonstrado em todas as formas de pesquisa utilizadas, apontaram para a utilização de apenas uma ferramenta com frequiência, ou seja, a grafologia. Tais dados sinalizavam que as demais práticas não compunham a realidade organizacional, e, desta forma, não poderiam ser caracterizadas como uma alternativa à prática empresarial na gestão de pessoas. Por esta razão, optou-se por mudar a implementação da estratégia proposta inicialmente e buscar outras formas de garimpagem desses dados, antes de concluir por sua não utilização.

\footnotetext{
${ }^{18}$ Empresa 1.
} 
Diante dessas dificuldades, por sugestão da orientadora, buscou-se contatar profissionais que prestam serviços às organizações, como especialistas em práticas alternativas. De acordo com o projeto inicialmente formulado, esses profissionais seriam entrevistados apenas em paralelo às organizações. No entanto, foi por meio deles que a pesquisa pôde ser efetivada: foi com a ajuda de algumas dessas pessoas, que mantiveram contato com as organizações para as quais prestavam serviços, e cujos representantes aceitaram ser entrevistados.

No total, foram entrevistados 18 especialistas e 11 gerentes e/ou empresários. O resultado dessas entrevistas está descrito nos dois próximos tópicos.

\subsection{Práticas alternativas na visão dos especialistas}

O perfil dos respondentes mostra que a maior parte é constituída de profissionais em idade madura (Gráfico 6), que possui longa experiência no tocante a essas práticas (Gráfico 7). Esses dados podem evidenciar a tendência das pessoas virem a se interessar por esse tipo de ferramenta apenas na idade madura ou, ainda, o reduzido interesse dos jovens por atuarem com práticas dessa natureza.

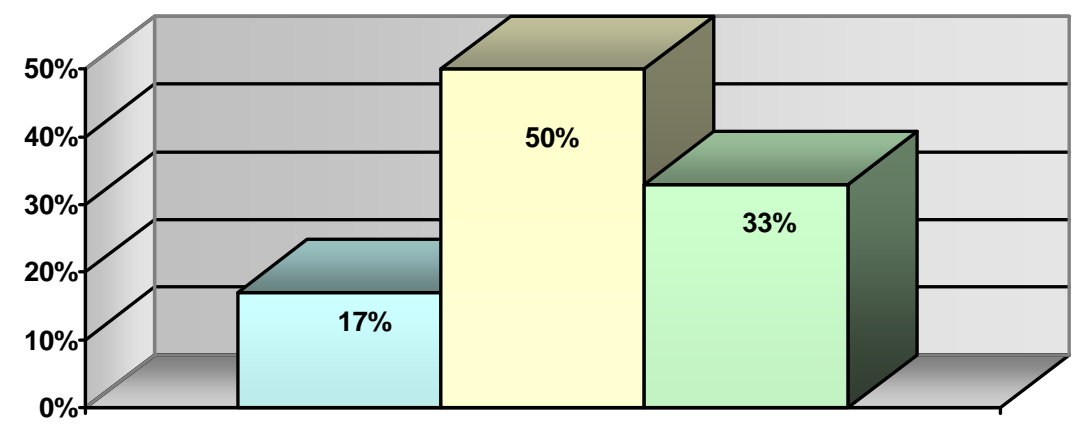




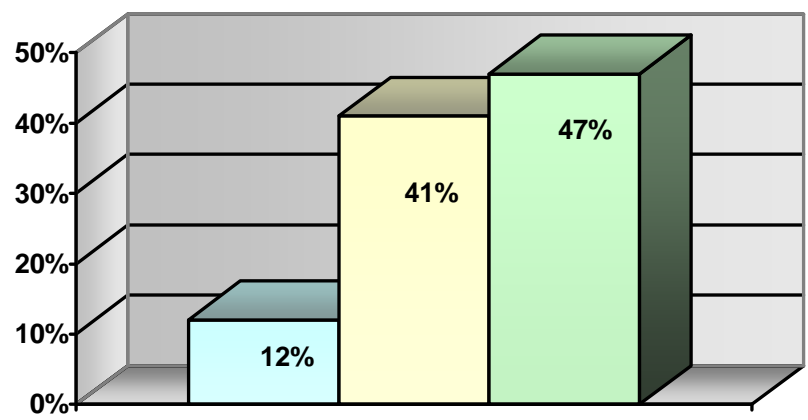

$\square$ Mais de 1 e menos de 5 anos

$\square$ Mais de 5 até 10 anos

$\square$ Acima de 10 anos

Gráfico 7 - Tempo de experiência na atividade

A formação escolar dos entrevistados é diversificada, o que é compreensível, uma vez que a utilização dessas ferramentas não exige qualquer tipo de formação escolar regular. De toda forma, o fato de $72 \%$ dos entrevistados terem concluído a formação superior é um indicativo de que essas práticas não estão relacionadas à ausência de escolaridade (Figura 17).

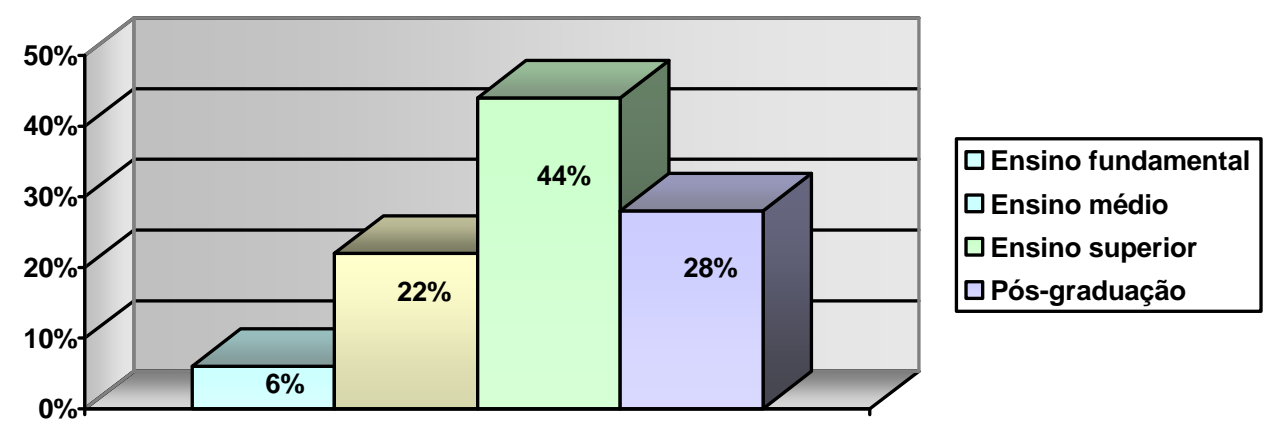

Gráfico 8 - Respondentes, por formação escolar

No que se refere à especialidade dos profissionais, embora cada um deles demonstre maior afinidade com uma ferramenta, alguns informaram que atuam, ainda que esporadicamente, em mais de uma prática, conforme Tabela 10.

Dentre os especialistas entrevistados:

- Dois utilizam somente a astrologia como prática profissional.

- Três utilizam somente a grafologia como prática profissional. 
- Um utiliza somente a musicoterapia como prática profissional.

Os demais, embora utilizem uma das ferramentas como prática principal, apóiam-se também em outras práticas, de modo complementar. É o caso, por exemplo, de especialistas em feng shui que se apóiam também em ferramentas como a radiestesia, a aromaterapia, os cristais e/ou essências florais. Um especialista utiliza a astrologia e o feng shui como práticas profissionais, mas atua em parceria com profissionais especializados em outras práticas, fornecendo um serviço de análise multiprofissional, envolvendo astrologia, numerologia, feng shui, grafologia e eneagrama. As especialistas em shiatsu atuam também com aromaterapia como ferramenta de apoio. Todos os profissionais entrevistados atuam ou atuaram em empresas como consultores, embora nem todos tenham indicado as empresas com as quais trabalharam para serem analisadas. Notadamente no caso da numerologia, um profissional disse ter consultado vários de seus clientes, mas nenhum deles aceitou ser entrevistado, mesmo com a garantia do anonimato.

Tabela 4 - Práticas alternativas, por especialistas

\begin{tabular}{|l|c|c|}
\hline \multicolumn{1}{|c|}{ Ferramenta } & $\begin{array}{l}\text { Ferramenta(s) utilizada(s) } \\
\text { rotineiramente pelo especialista } \\
\text { em empresas }\end{array}$ & $\begin{array}{l}\text { Ferramenta(s) utilizada uma } \\
\text { ou mais vezes pelo } \\
\text { especialista em empresas }\end{array}$ \\
\hline Aromaterapia & 1 & 4 \\
\hline Arte terapia & 0 & 1 \\
\hline Astrologia & 4 & 1 \\
\hline Baralho das Manchas & 0 & 1 \\
\hline Cosmologia & 1 & 0 \\
\hline Cristais & 0 & 3 \\
\hline Eneagrama & 0 & 1 \\
\hline Essências Florais & 1 & 4 \\
\hline Feng Shui & 4 & 4 \\
\hline Grafologia & 3 & 0 \\
\hline I-ching & 1 & 1 \\
\hline Iridologia & 0 & 1 \\
\hline Massagem ayurvédica & 0 & 1 \\
\hline Musicoterapia & 1 & 4 \\
\hline Numerologia & 1 & 3 \\
\hline Radiestesia & 2 & 2 \\
\hline Reiki & 0 & 1 \\
\hline Reflexologia & 0 & 3 \\
\hline Shiatsu & 2 & \\
\hline & & \\
\hline
\end{tabular}




\subsubsection{Trajetória de vida dos especialistas}

Durante cada entrevista, solicitou-se aos especialistas que fizessem um relatório de sua trajetória de vida, até o momento em que começaram a atuar profissionalmente com a ferramenta alternativa, da qual se tornaram especialistas. Foi-lhes solicitado ainda que citassem os momentos de crise e de oportunidade ao longo dessa trajetória e, ainda, o que os levou a trabalhar com esse tipo de abordagem.

Apesar das diferenças entre as práticas analisadas, verificou-se que a aproximação da ferramenta alternativa ocorreu, na maior parte das vezes, a partir de um processo de ruptura: em quatro casos, as razões foram de ordem pessoal (em três casos, por separação conjugal, e um caso por separação de amigo), e, em nove casos, as razões foram relativas ao desligamento de empresas ou instituições, nas quais os entrevistados trabalhavam. Os demais referem uma trajetória de busca para resolver dúvidas internas ou um percurso natural que os levou à prática sob pesquisa.

Embora as ferramentas alternativas sejam conhecidas no mercado, por sua proximidade com o ocultismo e as religiões mais espiritualistas, apenas uma entrevistada refere proximidade maior de seu trabalho com o espiritismo. Outra pessoa, especialista em feng shui, relata que muitos fatos são inexplicáveis em sua área pois, na Idade Média, os manuscritos sobre essa ferramenta foram destruídos de tal forma que, hoje, se sabe que dá certo mas não há explicação científica para o que ocorre. Os demais ou não mencionaram algum paralelo entre religiosidade e sua profissão, ou relataram apenas filosofia de vida voltada para a crença nas pessoas.

As razões que levaram a essas buscas são variadas: curiosidade, o desejo de melhorar a qualidade de vida das pessoas, atuação em recursos humanos, são alguns dos motivos citados pelos entrevistados.

Os relatos estão descritos a seguir. Os entrevistados foram agrupados de acordo com a ferramenta com a qual são mais conhecidos no mercado. 


\subsubsection{Astrologia}

Profissional 1 - A entrevistada foi diretora de uma pequena empresa de construção civil e vivenciou os altos e baixos desse setor, incluindo o trabalho em uma construtora que faliu e, em outro momento, a situação de um colega que utilizou seu nome para criar outra construtora, a qual, tempos depois, também começou a apresentar problemas financeiros. Na época foi estudar análise de sistemas no Rio de Janeiro e, como não tivesse formação em programação, resolveu abandonar o curso. Seus amigos então a levaram a conhecer o tarô, prática que ela também não gostou e, depois, a astrologia, mediante um programa por computador.

Relata que se encantou pela astrologia, porque a ferramenta adequava-se à sua formação de engenheira, por se tratar de um programa matemático. Decidiu, então, se submeter a um curso de formação. No terceiro ano de curso, foi convidada a lecionar na escola e após cinco anos de prática da astrologia começou a atender.

Algum tempo depois, a entrevistada vendeu sua parte na construtora e decidiu, então, se voltar integralmente para a astrologia. Abriu uma escola, a princípio com alguns colegas, os quais, logo depois, optaram por sair do projeto. Ela caminhou sozinha e hoje a escola é também uma pequena editora. Além disso, atua paralelamente como presidente do Sindicato dos astrólogos do Rio de Janeiro (Senarj).

Crises/Oportunidades: Crises nas empresas de engenharia nas quais trabalhou a levaram a procurar outros caminhos.

Momento em que se interessou por práticas alternativas: Foi apresentada à astrologia através de amigos.

Profissional 2 - A entrevistada informa que é do signo de virgem, tendo se iniciado na astrologia há 12 anos. Durante quatro anos, restringiu suas atividades apenas ao atendimento de amigos, além de ter se distanciado dessa área durante algum tempo. Conta que trabalhava em uma empresa multinacional eletroeletrônica, como diretora de assistência técnica para o Brasil. No início dos anos 2000, foi desligada da empresa e, como tivesse chegado aos 40 
anos de idade, encontrou dificuldade em se reempregar, tendo permanecido em torno de um ano sem qualquer atividade remunerada.

O retorno à astrologia aconteceu a partir de um curso que fez, cujo exercício exigia a montagem de uma empresa fictícia. A opção da entrevistada foi por criar uma empresa que atuasse com astrologia. Procurou então traduzir sua idéia em experiência concreta, e, como resultado, vendeu 12 mapas, em dois dias, com um faturamento de $\mathrm{R} \$ 2.000,00$. A partir dessa experiência, criou a empresa de fato, no ano de 2002.

No ano seguinte, participou de uma feira de RH e de um Fórum de Práticas Alternativas, promovido pela Associação Paulista de Recursos Humanos (APARH). Segundo ela, seu maior problema foi vencer o próprio preconceito de ser astróloga; por isso, optou por ser chamada de cosmo-analista, como define o Sindicato dos Astrólogos do Rio de Janeiro (SINARJ).

Seu trabalho atualmente consiste no atendimento a diretores, pois os considera o reflexo da empresa. Além do atendimento pessoal, trata o ambiente físico, a estrutura da empresa e os objetos, com cristais e aromas, ou indica um profissional, quando não é área de sua especialidade.

Conclui que uma das maiores lições que teve foi a de recuperar sua identidade como pessoa, sem vínculo a uma empresa, e deixar de ser executora de ações para se tornar planejadora, uma vez que, antes, apenas fazia o que fora definido por outros. O trabalho que desenvolve prevê uma análise com base na astrologia e feng shui, realizados por ela, além de numerologia e grafologia, cujas análises são feitas por profissionais especializados.

Desenvolveu esse produto para se diferenciar no mercado. Teve um ótimo resultado: cobra em torno de $\mathrm{R} \$ 1.200,00$ a $\mathrm{R} \$ 1.500,00$ por trabalho realizado, embora o número de solicitações dessa natureza seja pequeno: em dois anos, vendeu cerca de cinco trabalhos com essa amplitude. Segundo ela, o cliente tem curiosidade em saber o que vai acontecer, mas não pratica a orientação recebida, o que resulta em pouco retorno. É mais fácil vender para um cliente pessoa física. 
Nesse sentido, tem atendido com mais frequiência o próprio empresário. Para empresas propriamente ditas, fez apenas dois atendimentos até o momento da entrevista. O primeiro caso teve início com o atendimento ao próprio empresário que, satisfeito com a análise recebida, decidiu fazer o mapa da empresa (ele e o sócio), tomando o trabalho como apoio às suas decisões.

Crises/Oportunidades: A grande crise ocorreu aos 40 anos, quando perdeu seu emprego como diretora. A oportunidade surgiu a partir do curso que fez, na época, e que a levou a planejar a criação de uma empresa de astrologia.

Momento em que se interessou por práticas alternativas: desde 1993, ocasião em que fazia mapa para seus amigos. Profissionalmente, ocorreu somente em 2002, após ter montado a empresa fictícia, durante um curso.

Profissional 3 - O entrevistado, que tem formação em engenharia, refere ter trabalhado, durante alguns anos na área de Planejamento Estratégico em uma multinacional da área química. Nessa época é que se interessou por astrologia e resolveu atuar em paralelo nesta que se tornou sua segunda profissão. Seu interesse pela astrologia surgiu porque acredita que a prática permite uma abordagem humana, através do uso de dados exatos (cálculo do mapa astrológico).

Ao desligar-se empresa na qual trabalhava, em 1992, decidiu atuar como astrólogo empresarial. Aproveitou seus conhecimentos em planejamento, administração e processos de tomada de decisão para atender a presidentes, diretores e/ou gestores das áreas de planejamento e finanças. Atualmente, utiliza apenas em torno de $10 \%$ de seu tempo no atendimento a grandes empresas, pois a maior parte de sua clientela constitui-se de médias empresas.

Crises/Oportunidades: Considera que aos 30 anos teve sua maior crise de carreira. Na época, optou por abrir uma empresa de astrologia. Fez parceria com a seleção de executivos: astrologia vocacional direcionada à carreira e astrologia empresarial. A partir da criação do telefone 0900, que disponibilizava atendimento telefônico em astrologia, verificou uma queda 
no atendimento (durante e após esse período, percebeu uma retração do mercado). Agora considera que está passando por um novo patamar, mais seletivo e profissional.

Momento em que se interessou por práticas alternativas: Quando trabalhava na área de Planejamento Estratégico da multinacional da área química.

Profissional 4 - A entrevistada cursou Administração de Empresas na FEA/USP. Depois de formada, trabalhou durante dez anos como gerente financeira. Paralelamente, estudava temas relacionados à dimensão holística e, já nessa época, começou a fazer estudos astrológicos individualizados.

Ao desligar-se da empresa, refere ter passado por um período de muitas descobertas relacionadas à energia e à aura. Foi então que decidiu não mais retornar ao campo empresarial e dedicar-se apenas ao atendimento em práticas alternativas. Nesse período, fez um curso voltado para a astrologia empresarial e, há cinco anos, começou a prestar serviços a uma das empresas analisadas neste estudo.

Atualmente, é terapeuta holística, prestando serviços de astrologia, numerologia, feng shui e $i$ ching.

Crises/Oportunidades: Quando saiu da empresa onde era contratada, resolveu não mais retornar a trabalhar como empregada.

Momento em que se interessou por práticas alternativas: Desde pequena. Adorava ver filmes de fadas e ficção científica. Procurava respostas para jargões como "quando a esmola é demais, o santo desconfia”. Sua busca era pela felicidade e questionava estes jargões: porque é preciso desconfiar quando se é feliz? Considera que sua vida é sagrada, a doença tem um significado, e procura estar sempre em harmonia. 


\subsubsection{Aromaterapia e Florais}

Profissional 5 - Começou trabalhando em empresa, chegando a chefe de Departamento de Pessoal. E sempre se interessou pelo valor humano. Tanto assim que era solicitada pelos empregados a fazer curativos e prestar apoio pessoal. Em 1981, após discutir com uma amiga, com quem pretendia montar uma clinica, adquiriu uma forte alergia. Passou por vários tratamentos da medicina tradicional e por terapia, sem resultado.

Em 1982, participou de um curso de autoconhecimento, em São Paulo, e gostou do resultado, pois, ao aplicá-lo em si própria, curou-se da alergia. Passou a fazer estágio na clínica da própria escola e desde então não mais parou. Ampliou seus conhecimentos participando de grupos de estudo e freqüentando outros cursos como o de astrologia, conhecendo várias técnicas de massagens, aromaterapia, terapia floral, etc. A Associação Brasileira de Terapia de Floral de Bach teve início na sede da farmácia na qual ela presta serviços atualmente. Em 1989, saiu da empresa em que trabalhava e passou a se dedicar apenas às praticas alternativas.

Algum tempo depois, foi convidada a participar como membro da equipe de Zulma Reyo, americana, fundadora da Alquimia Interior no Brasil e, mais tarde, tornou-se sócia com outros profissionais. Naquela entidade, além dos trabalhos individuais, como terapeuta corporal, atuou também em conjunto nos workshops, e programas desenvolvidos, como o de atendimento integrado, em conjunto com médicos, psicólogos, terapeutas corporais e energéticos, da clinica holística da Alquimia, e na clinica psicológica, como arte-terapeuta, além de auxiliar os profissionais internacionais convidados pela empresa.

Em todos esses trabalhos, sua experiência na área de terapia corporal, como sobre florais e aromas, era integrada aos trabalhos desenvolvidos. Em novembro de 1999, foi para Portugal e, quando retornou, desligou-se da Alquimia.

Continuou seus estudos e aprofundou-se em terapia da árvore familiar, feng shui, radiestesia e, mais recentemente, em constelação familiar. Refere utilizar todo o seu conhecimento de acordo com a necessidade. Atende geralmente a diretores de empresas porque acredita que eles refletem a empresa. Trabalha juntamente com seu professor de radiestesia, atendendo 
pessoas físicas e jurídicas, apontando o motivo e A origem dos bloqueios e sugerindo tratamentos.

Crises/Oportunidades: Ao se separar da amiga com quem pretendia montar uma escola de consciência pelo movimento, desenvolveu uma alergia. Buscou tratamentos com corticóides, psicólogos, etc. e encontrou o resultado da cura no auto-conhecimento - que definiu a direção que deveria seguir em sua trajetória profissional.

Crises:

- Abandono de uma carreira e do salário estável (era chefe de pessoal) por uma carreira sem qualquer garantia de salário. Além disso, até hoje essas práticas não são reconhecidas.

- Desligamento da Alquimia Interior, em um momento de expansão da prática, na Europa, para seguir um trabalho pessoal.

Momento em que se interessou por práticas alternativas: Sempre teve interesse em ampliar a qualidade de vida das pessoas. Praticava esportes e sentia bem-estar, por isso acreditava que cada pessoa poderia se beneficiar de uma atividade diferente. Esta era a sua primeira idéia quando pretendeu montar uma escola de movimento com uma amiga.

O fato de ter contraído uma alergia, após a separação, curada por meios alternativos, a fez acreditar que este seria o seu caminho. Buscou e conheceu varias técnicas que promoviam o autoconhecimento, e como o macrocosmo se manifestava no microcosmo. Segundo ela, não apenas a astrologia, mas cada parte de seu corpo também representa o todo. Assim, tem-se o reflexo de todo o corpo em cada parte, como na orelha, pés, nariz, dentes, íris, etc. E não apenas o seu físico mas também o seu equilíbrio ou desequilíbrio.

A partir dessa observação, percebeu a importância da observação e identificação dos desequilíbrios que se manifestam no corpo "antes mesmo de afetarem o corpo físico como método de prevenção de doenças, e como obter esses resultados através das várias linhas alternativas como, por exemplo, o shiatsu, o tai chi, a dança, a yoga, etc.“. 
Em seu trabalho, começou a perceber também a influência do meio ambiente, o que a levou ao estudo do feng shui e do terreno, através da radiestesia. Para ela, seguir os ritmos da natureza não era suficiente. Mais recentemente, relata estar percebendo a influência dos antepassados, por isso vem estudando a terapia da árvore familiar e constelação familiar, na qual, segundo a entrevistada, o ser humano não se vê só, mas fazendo parte de um sistema em que a harmonia ou desarmonia de cada membro interfere no todo. E acredita que a única linha mantida é do agradecimento e do amor.

\subsubsection{Feng Shui}

Profissional 6 - O entrevistado é formado em Economia. Trabalhou em um banco de investimentos e depois em uma multinacional. Desde os 16 anos tem contato com florais de Bach, tendo participado de vários eventos relativos a essa temática, o que facilitou seu autoconhecimento. Paralelamente ao trabalho empresarial, fazia cursos de reiki, numerologia, astrologia e apaixonou-se pela área. Tornou-se confidente das pessoas e percebeu que fazia bem a ele e aos outros. Por outro lado, a empresa o estressava. Em dado momento, foi-lhe colocada a perspectiva de mudança da empresa na qual trabalhava, para outro Estado. Acreditou que era o momento de fazer uma opção e saiu do emprego. Desde então, vem se dedicando ao trabalho com terapia floral, à radiestesia e ao feng shui.

Crises/Oportunidades: Sua saída para trabalhar somente com feng shui não gerou crise, apenas insegurança.

Momento em que se interessou por práticas alternativas: Sempre gostou de dar atenção à qualidade de vida. Queria entender as energias que têm num ambiente e as quais as pessoas não conseguem perceber. Todavia, seu lado lógico instigava-o a querer conhecer parâmetros de mensuração para aplicar, por exemplo, uma cor. Isso o levou ao feng-shui.

Profissional 7 - Sempre trabalhou com energias, embora não soubesse. Foi casada até os 35 anos, quando, então, se separou e ficou com seus três filhos. Quando casada, tinha um belo jardim em sua casa, que ela própria cuidava. Com a separação, utilizou essa sua habilidade, 
que era apreciada por todos que a visitavam, e tornou-se paisagista. Depois de algum tempo nessa área, foi trabalhar como gerente geral do Jóquei Clube de São Paulo e, já nessa época, usava sua capacidade energética na relação com os empregados. Quando saiu do Jóquei, foi para os Estados Unidos e, lá, resolveu fazer cursos relacionados ao feng shui. Quando retornou ao Brasil, especializou-se na área, além de capacitar-se em aromaterapia e radiestesia. Desde então, ministra aulas e é consultora em feng shui. Refere ser adepta da escola do chapéu negro, que não utiliza a bússola.

Crises/Oportunidades: Aos 35 anos, com a separação conjugal, começou a trabalhar como paisagista. Aos 49 anos, com o desligamento do Jóquei Clube, passou a se dedicar ao feng shui.

Momento em que se interessou por práticas alternativas: Participou como aluna da primeira turma de cursos de florais, por sua ligação com o paisagismo.

Profissional 8 - A entrevistada é arquiteta há cerca de 40 anos. Durante 35 anos trabalhou com projetos e construção civil em sua própria empresa. Refere que, em dado momento, cansou-se dessa atividade e começou a estudar feng shui. Isso porque ela percebia que, embora fizesse seu trabalho como arquiteta com o mesmo carinho e dedicação, o resultado nem sempre era satisfatório. Cita o exemplo de um cliente, diretor de uma grande empresa, para o qual fez três projetos de casa. Os dois primeiros projetos foram muito bons e, paralelamente, a vida do empresário caminhou numa curva ascendente. Já no terceiro projeto, refere ter sentido um incômodo, quando entrou na casa. O projeto ficou bom, mas, logo depois de tê-lo concluído e o cliente ter se mudado para aquela residência, ele começou a enfrentar problemas na empresa e a ter perdas significativas de seu patrimônio pessoal.

A proposta do feng shui surgiu a partir de impasses como esse. A entrevistada fez um curso com duração de dois anos e, depois disso, voltou à casa desse cliente. Verificou, então, que o imóvel tinha o que chamou de péssimas energias, e que um de seus donos, inclusive, teria morrido de forma trágica. Sua conclusão é que a escolha do imóvel não poderia ter sido pior. Situações como a descrita fizeram com que mudasse para a atividade atual, na qual trabalha como consultora em feng shui. 
Crises/Oportunidades: Quando começou a se incomodar com as razões que faziam com que nem sempre o resultado de seu trabalho fosse satisfatório.

Momento em que se interessou por práticas alternativas: Quando se cansou de atuar como arquiteta em construção civil e resolveu buscar respostas no feng shui para suas preocupações sobre os resultados do seu trabalho.

\subsubsection{Grafologia}

Profissional 9 - A entrevistada relata que iniciou sua trajetória profissional como assistente social do setor hospitalar, em que atuou durante sete anos. Logo após, aproveitou uma ótima oportunidade na área de recursos humanos. Decorridos 15 anos de experiência, vem atuando em recrutamento, seleção, avaliação de desempenho, treinamento e benefícios. O "encontro" com a grafologia aconteceu quando participou da equipe de uma consultoria de $\mathrm{RH}$, especializada nesse instrumento; refere ter sentido irresistível interesse e resolveu estudar e se aprimorar nessa prática, que ela considera fascinante. Atualmente, é consultora de RH, realizando trabalhos com ênfase na Grafologia.

Crises/Oportunidades: Para a entrevistada, as crises foram administradas como crescimento pessoal e profissional. O melhor a ressaltar foram os momentos em que teve oportunidade de aplicar a grafologia como instrumento para o autoconhecimento.

Momento em que se interessou por práticas alternativas: Destaca o ano de 1996, quando foi convidada a colaborar em uma empresa de consultoria em recursos humanos, com foco no recrutamento e seleção e na utilização da grafologia como método de avaliação. Ao iniciar as atividades nessa empresa, logo se identificou com o instrumento, até conseguir obter o aprendizado específico com um profissional qualificado durante dois anos. Desde então, vem estudando com a finalidade de aprimorar seus conhecimentos.

Profissional 10 - O entrevistado relata que, aos 16 anos de idade, entrou para a academia militar de Agulhas Negras. Já na época, interessou-se por grafologia. Em 1982, comprou um 
livro em espanhol, de autoria de Augusto Vells e, em 5 de fevereiro, escreveu para o autor e com ele começou a se corresponder. Em 1987, fez um curso de pós-graduação em Curitiba cujo tema abordava a grafologia em RH (hoje, avalia que questiona muito do que escreveu naquele texto). Desde então, começou a lecionar e a ministrar palestras sobre o assunto. Em 1991, escreveu o texto O que É Grafologia. Em 1993, foi lecionar no Centro de Psicologia Aplicada (Cepa), na cidade do Rio de Janeiro. Escreveu outros livros como Revele a sua Personalidade; Grafologia no Recrutamento; e Seleção de Pessoal. Refere ser dono da maior coleção de publicações sobre grafologia da América do Sul.

No que diz respeito ao trabalho para empresas, afirma ter realizado mais de 1.200 análises grafológicas para diferentes organizações. Há dois anos, ao entrar para a reserva, desligou-se das Forças Armadas e, desde então, dedica-se em tempo integral ao trabalho como especialista nessa ferramenta.

Crises/Oportunidades: Optou pela grafologia 15 anos atrás, quando analisou a perspectiva do salário dos militares e verificou ser o mais baixo ao longo da história, com tendência a permanecer dessa forma. Fez mestrado pelo exército, mas não se animou em avançar até o doutorado. Assim sendo, há dois anos, quando cumpriu o tempo exigido para a carreira militar, pediu seu desligamento e ficou apenas com a grafologia, cuja remuneração, segundo ele, é mais atraente do que a de militar.

Momento em que se interessou por práticas alternativas: Por curiosidade intelectual. Começou a ler por interesse próprio. Depois, por interesse financeiro, em face do salário dos militares. Passou a ser procurado em função da grafologia e optou por essa profissão.

Profissional 11 - Iniciou suas atividades em um banco de grande porte, como escrituraria. Em 1986, foi para a área de RH por estar se formando em Psicologia. Enquanto funcionária daquela instituição, selecionou empregados em todo o Brasil, o que a fazia viajar com frequiência. Em 1993, quando o banco passava por um processo de reengenharia, e sinalizou que as atividades de seleção seriam realizadas por uma consultoria externa, a entrevistada encarou o momento como uma oportunidade para iniciar a carreira como profissional liberal. 
Além disso, desejava atuar na área de treinamento e como esse projeto não se concretizou, decidiu desligar-se do banco.

Durante algum tempo, trabalhou para a organização como prestadora de serviços, até que ela foi adquirida por outra. Na época, ela já havia conseguido ampliar sua carteira de clientes e não teve maiores problemas. Hoje, atua como consultora em organizações de pequeno, médio e grande portes em recrutamento e seleção e como head hunter.

Crises/Oportunidades: Em 1993, quando se desligou do banco. Depois, já como profissional liberal, nova crise se instaurou porque ela temia não conseguir dar conta das imposições de uma atividade dessa natureza, no que diz respeito à prospecção de novos negócios, gestão financeira, execução técnica, etc.

Momento em que se interessou por práticas alternativas: Quando trabalhava no banco, o presidente fez uma análise com uma grafóloga experiente e gostou dos resultados. Apresentou a especialista para a equipe de Recrutamento e Seleção, da qual ela fazia parte, e pediu que a grafologia fosse incluída no processo seletivo. Durante algum tempo, aquela profissional prestou serviços ao banco. A entrevistada interessou-se muito pelos laudos que recebia e resolveu fazer um curso básico. Depois disso, começou, ela própria, a fazer análises e não parou mais.

Já como consultora, aprofundou seus estudos, embora de maneira solitária, pesquisando livros sobre o assunto. Somente há pouco tempo, ao ler um livro publicado por um grafólogo, se interessou em manter contato com ele por $e$-mail e iniciou o curso de formação em grafologia.

\subsubsection{Musicoterapia}

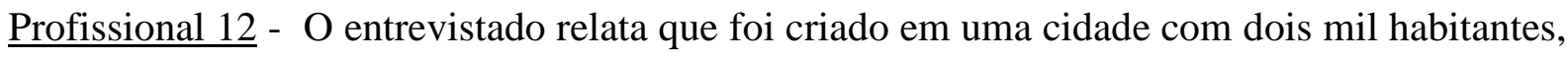
situada no extremo sul do Brasil. Aos nove anos de idade, numa tarde, assistia à televisão, com seu irmão, quando ouviu um som maravilhoso. Semanas depois, a mãe apresentou fotos de instrumentos musicais para que ele a identificasse: era uma flauta de bambu. Como na cidade não existisse o instrumento ou professor de música, ele mesmo construiu a flauta e foi 
para o mato, onde começou a imitar os sons dos pássaros. Aos dez anos, passou para o violão. Aos 11 anos, montou um grupo de baile e aos 14 saiu de casa. Tinha uma dúvida de pesquisa, que o vem acompanhando ao longo da vida: qual a intenção do som e qual a sua extensão? Para responder a essa pergunta, foi para fora do Brasil. Morou em vários países da América do Sul. No Brasil, morou por um ano e dez meses com índios, na Ilha do Bananal. Desenvolveu um método que chama de Sistema de Organização Musical (SOM).

Seu trabalho é com criatividade sonora. Ele acredita que qualquer um pode tocar um instrumento. Seu papel é criar condições para que a pessoa faça essa criação. Depois de dez anos viajando, foi morar em Joinville/SC, cidade onde ficou por oito anos. Foi lá que começou a trabalhar com psicólogos de empresas. Em 1996, participou de um workshop de criatividade e foi o destaque dentre cerca de 200 apresentações. Desde então, os convites de empresas surgiram e, por essa razão, ele resolveu mudar sua residência para São Paulo. Hoje, atua como consultor em trabalhos de treinamento e desenvolvimento empresarial.

Crises/Oportunidades: Aos nove anos, quando ouviu o som que o encantou, e quando esteve na Ilha do Bananal e foi forçado a dormir no alto das árvores, correndo risco de morte, teve reforçadas suas convicções para trilhar o caminho da música, e, em 1996, quando apresentou seu trabalho no workshop, na cidade de Belo Horizonte/MG.

Momento em que se interessou por práticas alternativas: Aos nove anos de idade.

\subsubsection{Numerologia}

Profissional 13 - A entrevistada conta que tem contato com ferramentas alternativas desde os 18 anos. Parou por ocasião de sua formação superior e retornou já profissionalmente aos 48 anos embora informe que durante esse tempo tenha continuado estudando.

Crises/Oportunidades: Não relata algum momento especial. Refere apenas que tanto as crises quanto as oportunidades já conhecidas antecipadamente acrescentaram aprendizados e maturidade à sua vida. 
Momento em que se interessou por práticas alternativas: Antes da trajetória profissional já havia interesse e buscas, inicialmente voltadas para a Teologia.

Profissional 14 - Relata que a maior parte de sua vida profissional foi voltada para a numerologia. Trabalhou algum tempo na área de treinamento, mas cansou de ser empregado e decidiu dedicar-se apenas a essa ferramenta. O fato aconteceu há 20 anos e, desde então, vem trabalhando como professor de cabala e numerologia, além de atender a empresários e empresas.

Crises/Oportunidades: Trabalhou como secretário e depois dedicou-se à área de treinamento. Em dado momento, passou a ficar triste porque, em sua avaliação, treinava pessoas para trabalhar mais e ocupar o lugar de outras pessoas. Decidiu, então, sair da empresa. Ficou inativo durante oito meses até que fez o mapa numerológico para uma pessoa, cobrou pelo trabalho, e nunca mais parou.

Momento em que se interessou por práticas alternativas: Seu interesse pela numerologia vem desde os cinco anos de idade. Aplica essa ferramenta profissionalmente há 20 anos.

\subsubsection{Radiestesia}

Profissional 15 - Embora seja de família católica (descendente de italianos, espanhóis), aos 16 anos de idade a entrevistada tornou-se espírita, rompendo com as tradições familiares em torno da religião. Casou-se e assim permaneceu por 24 anos. Dessa união, nasceram seus dois filhos. Logo após a separação, aos 45 de idade, foi trabalhar com vendas, embora não fosse esta a sua vocação. Três meses depois, uma de suas filhas sofreu grave acidente e ficou nove meses sem trabalhar, o que muito a desestruturou. Quando a filha retornou ao trabalho, foi a entrevistada que adoeceu e ficou internada. Nesse período conturbado de sua vida, também seu pai adoeceu, com hipertensão, e depois com a doença de Alzheimer, até que faleceu alguns anos depois. Como o pai era dono de uma administradora de imóveis, a entrevistada foi trabalhar na empresa, responsabilizando-se pelas áreas de pessoal e finanças e ali permaneceu por 11 anos. 
Quando ainda trabalhava na imobiliária, uma amiga sugeriu que fizesse um curso de radiestesia e, como não tivesse como arcar com o custo, esta lhe pagou a primeira mensalidade. A entrevistada gostou do conteúdo e do professor e resolveu cursá-lo novamente. Seu interesse pelo assunto foi tal que convenceu o professor a criar disciplinas de aprofundamento relativas à radiestesia. Ela se responsabilizava por buscar alunos e preparar as apostilas e ele por ministrar os cursos. Com o tempo, o professor, que também era doente, afastou-se e ela assumiu as aulas, embora continuasse com seu trabalho na imobiliária.

Em um dado momento, o professor sugeriu que rompesse com o trabalho na imobiliária que, para ela, era muito desgastante e se dedicasse apenas à radiestesia. Embora contra a opinião da família, a entrevistada aceitou o desafio. Vendeu sua parte do negócio para o outro sócio, e passou a se dedicar apenas a essa atividade.

Com o tempo, começou a prestar serviços para empresas. Sua primeira experiência foi em uma organização cujo dono tinha a esposa com leucemia. Através da radiestesia, conta ter verificado que a tendência para essa doença já existia e que se potencializou, na cliente, em função do local onde morava. O trabalho por ela realizado encantou o marido, que era um empresário. A partir de então, ela passou a executar trabalhos para a empresa desse cliente, que a indicou para outras organizações, de modo que, hoje, a maioria de sua clientela é constituída de empresas.

Crises/Oportunidades: Segundo a entrevistada, o momento de maior crise em sua trajetória profissional foi quando seu professor sugeriu que ela abandonasse o trabalho na imobiliária e passasse a se dedicar apenas à radiestesia.

Momento em que se interessou por práticas alternativas: Aos 16 anos, quando se tornou espírita, teve início a sua mudança, que se consolidou aos 50 anos, quando passou a trabalhar com radiestesia.

$\underline{\text { Profissional } 16}$ - O entrevistado é europeu e foi no Exterior que conheceu a radiestesia, onde esta ferramenta é mais desenvolvida, mas ficou distante desse assunto durante um longo 
período. Iniciou o curso de arquitetura na Europa, mas não o concluiu. Por essa razão, trabalhou durante alguns anos, com a ex-mulher, em perícias judiciais. Segundo ele, algumas vezes o casal se deparava com questões que ficavam sem explicação. Como havia feito o curso de radiestesia, utilizou o pêndulo em um determinado caso e verificou que, na prática, a ferramenta tinha sentido. Foi nessa ocasião que resolveu continuar seus estudos com a ferramenta e não mais parou. Até cinco anos atrás, fazia essas análises sem interesse financeiro, uma vez que seus rendimentos vinham de trabalhos periciais.

Contudo, após a separação, abandonou a atividade e tentou outras atividades, que não lograram êxito. O trabalho como especialista foi assumido quando, após ministrar uma palestra sobre um tema relativo às suas crenças, mencionou a radiestesia e lhe foi solicitada uma análise, que ele cobrou determinado valor para realizar. Desde então, vem trabalhando apenas com radiestesia, sem nunca ter feito divulgação mas sempre por meio de indicação de clientes. Mesmo assim, relata que seu portfólio de clientes não pára de crescer, tanto de pessoas quanto de empresas.

Crises/Oportunidades: No momento da ruptura de seu casamento, que o fez buscar outras opções de trabalho. A maior oportunidade aconteceu quando, ao fazer uma palestra sobre um tema relativo à sua filosofia de vida, recebeu uma encomenda de trabalho com radiestesia. Desde então, nunca mais parou.

Momento em que se interessou por práticas alternativas: Sua trajetória começou com vivências em reiki, em que já é mestre, aliado ao conhecimento da filosofia pregada pelo indiano Sri Sathya Sai Baba.

\subsubsection{Shiatsu}

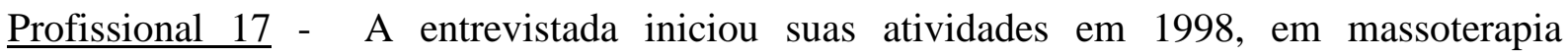
(massagem em si), com ênfase em shiatsu (que é a própria técnica). Há cerca de seis anos, presta serviços, como terceirizada, em uma empresa de cosméticos de grande porte, na cidade de São Paulo. Relata que, quando chegou a essa empresa, já havia uma equipe realizando 
esse trabalho em um espaço cedido. Ela foi levada para a empresa por uma pessoa conhecida e admitida inicialmente como empregada terceirizada.

A organização para a qual presta serviços já desenvolvia ações de Qualidade de Vida no Trabalho (tabagismo, LER) muito antes de sua chegada. A utilização de ferramenta alternativa foi feita com o apoio de uma assistente social, que lá trabalhava na época e que, após uma vivência realizada com os empregados próximo ao restaurante, convenceu a direção da empresa a montar o espaço, que ficou conhecido como Clube do Shiatsu. A iniciativa faz parte do programa de Qualidade de Vida no Trabalho (combate ao estresse).

Com a saída da empresa que prestava serviços à organização, a entrevistada ocupou o espaço. Começou sozinha e, aos poucos, foi ampliando o espaço físico e a equipe. O foco são as terapias orientais alternativas: além do shiatsu, trabalha atualmente com florais de Bach, reiki, massagem ayurvédica e reflexologia. Segundo a entrevistada, o toque da massagem é muito invasivo, e é necessário muito respeito por parte do profissional. O trabalho é muito enriquecedor pois o feedback é instantâneo.

Crises/Oportunidades: A dificuldade do trabalho preventivo e a falta de informação por parte da coordenação. Como oportunidade, refere o leque de opções de trabalho, atendimento e espaço que a empresa tem proporcionado à entrevistada.

Momento em que se interessou por práticas alternativas: Relata que quando não mais havia possibilidade de retorno ao mercado de trabalho, viabilizou um projeto antigo de ser autônoma. Começou a trabalhar com familiares, que atuam nesse ramo e, desde então, tem obtido resultados que considera muito positivos e que, aliados a outras técnicas alternativas, lhe proporcionam um ganho ainda maior.

Profissional 18 - A especialista formou-se em Psicologia, pela Universidade Estadual do Rio de Janeiro, em 1988 e, desde então, tem atuado na área de educação, desde a infantil até o ensino superior. Durante toda a sua vida, refere ter se relacionado com práticas alternativas. Inicialmente, seu contato foi com o tarô e a astrologia, estimulada pela psicologia de Jung. Depois, se interessou pelas práticas corporais e passou a ter contato com a Medicina 
Tradicional Chinesa e Oriental. Fez cursos de shiatsu e shantala. Há cinco anos atua com programas de qualidade de vida no trabalho, usando como referência a prática do shiatsu. Paralelamente, também coordena curso de pós-graduação em gestão de recursos humanos em uma universidade na cidade do Rio de Janeiro e ministra o módulo de Gestão do Clima Organizacional e Qualidade de Vida no Trabalho.

Crises/Oportunidades: Em 1992, deu início a um negocio próprio, em conjunto com uma amiga de faculdade. Montaram uma creche, em Jacarepaguá/RJ. Em 1996, uma grande enchente no Rio de Janeiro a atingiu o empreendimento e elas perderam o negócio. Relata que sua vida e sua carreira foram redirecionadas, a partir desse grande momento de crise.

Uma das oportunidades decorrentes do acidente na creche foi o ingresso na pós-graduação, em busca de novas oportunidades de carreira e a descoberta da Qualidade de Vida no Trabalho (QVT). Duas importantes realizações vieram como conseqüência: Iniciou sua consultoria na área e hoje administra grandes contratos, com mais de 50 mil atendimentos de shiatsu expresso/ano. Além disso, assumiu a coordenação da pós-graduação pouco tempo após o término do curso.

Momento em que se interessou por práticas alternativas: Sempre se interessou pelo assunto, por ter uma afinidade com práticas mais humanistas, mais holísticas, que entendem o homem como um ser integral. Entretanto, foi durante a pós-graduação que entrou em contato com as ferramentas da QVT e buscou uma forma de aplicá-las no Rio de Janeiro, uma vez que, em São Paulo, as práticas e a produção de conhecimento já aconteciam na Universidade de São Paulo (USP), na Associação Brasileira de Qualidade de Vida (ABQV), em várias empresas de consultoria instaladas, e com programas de atividade física, com sucesso. As práticas alternativas eram ainda apresentadas de forma pouco estruturada. Considerou que, com uma visão organizacional vinculada a indicadores de resultados, seria uma boa oportunidade para ter um diferencial de sucesso no início do seu trabalho. Relata ainda estar buscando critérios e indicadores que, associados à sua prática, possam ser melhor utilizados pelas organizações, tanto que inscreveu um pôster para o próximo congresso da International Stress Management Association (ISMA) sobre essa questão. 


\subsubsection{Resultados obtidos com a aplicação das práticas alternativas, na visão dos especialistas}

\subsubsection{Astrologia}

1. Identifica o potencial de crescimento e diversificação da empresa.

2. Contribui para o planejamento estratégico, ajudando o administrador a decidir se reduz ou se expande sua organização Um entrevistado relata um estudo astrogeográfico, que realizou para uma empresa de biquínis, no qual o resultado foi o aumento nas vendas para o exterior.

3. Satisfação plena. O forte da ferramenta é o autoconhecimento e o preciso trabalho de previsão, principalmente quando se faz um trabalho multidisciplinar que envolva mais de uma ferramenta como, por exemplo, numerologia, grafologia e feng shui.

4. Não dispõe de dados para comprovar, pois eles são de propriedade da organização em que presta serviços. As informações que dispõe são apenas aquelas que ouve das pessoas com as quais se relaciona. Cita dois mapas de empresas, com pessoas excelentes, mas cujos mapas astrológicos não combinavam com a empresa. Ambos não permaneceram na organização.

\subsubsection{Aromaterapia}

1. Os resultados da aplicação são imediatos, no ambiente físico.

2. Conforme o aroma, haverá maior concentração e memória, características necessárias para uma fábrica; maior capacidade de digestão e de claridade mental, para reuniões e palestras, etc.; pode ser misturado com florais, para ampliar o poder de atuação.

3. Após algumas horas de contato com o aroma, este pode tornar-se imperceptível, porém seus efeitos permanecem, pois penetram na corrente sanguínea através das vias olfativas. 
4. Pode ser percebida sua atuação, pois as pessoas começam a sentir a falta do aroma, quando ele deixa de ser colocado no ambiente.

5. Melhora o ambiente de trabalho e gera melhor relacionamento e crescimento (além da aromaterapia, também os florais e cristais contribuem para esse resultado).

\subsubsection{Feng Shui}

1. "A casa é como um espelho de quem a habita." O feng shui define pontos de desequilíbrio e formas de corrigi-los.

2. Melhora o ambiente de trabalho e gera melhor relacionamento e crescimento.

3. Ação difícil de ser dimensionada. O que ocorre é que as empresas destravam e as mudanças passam a acontecer de forma rápida e leve. O feng shui trabalha o ambiente e a pessoa no processo. Em ambientes nos quais não há o que fazer, tem-se proposto a criação de ambientes de descompressão.

4. Os resultados não são previsíveis. Em uma videolocadora, por exemplo, o dono teve que trocar os funcionários, após o uso, pois, de alguma forma, eles deixaram de ir trabalhar: um deles era assaltante e morreu; outro, passava informações para o concorrente; não se lembra do que ocorreu com o terceiro empregado.

5. A utilização do feng shui promove a decisão.

6. Cria insights para formas novas de trabalho.

7. Proporciona integração familiar, harmonia, crescimento financeiro.

8. Os resultados são muito rápidos. O feng shui melhora em torno de $30 \%$ do problema. 
9. Normalmente, o especialista é procurado pelo cliente que está em busca de prosperidade. A maior parte se esquece dos aspectos relativos à saúde.

\subsubsection{Grafologia}

1. As empresas dão excelente feedback. O resultado mais palpável é a diminuição do turn over.

2. Há diminuição do tempo para recolocação (algumas empresas pedem carta de próprio punho, no anúncio do jornal, reduzindo o tempo para contratação, pois assim é possível selecionar pessoas para outras etapas do processo).

3. Proporciona informações amplas das características de personalidade do profissional testado.

4. A qualidade total visa o crescimento profissional.

5. Há melhoria no aproveitamento e incremento da produtividade dos funcionários na empresa.

6. Proporciona muita confiabilidade. Um de seus clientes (empresa de grande porte) não faz qualquer contratação, sem que o candidato seja submetido a análise grafológica.

7. Permite acompanhar o grau de maturidade pela qual passa uma pessoa, desde que esta seja submetida ao exame periodicamente.

\subsubsection{Musicoterapia}

As pessoas entram desconfiadas. Em três minutos, com som, ele consegue fazê-las dormir ou ficarem completamente acordadas. 


\subsubsection{Numerologia}

1. Proporciona melhoria na produtividade - motivação e economia para a empresa.

2. Permite o autoconhecimento, inclusive de vidas passadas.

3. Há adequação profissional e social.

\subsubsection{Radiestesia}

1. Em seleção de pessoal, a entrevistada recebe continuamente pedidos para avaliação de potencial do candidato. Desconhece os resultados, mas houve aumento do trabalho, com novas indicações.

2. É procurada pelos empresários para grandes decisões.

3. Provoca maior facilidade e consciência nas decisões: por exemplo, indica onde perfurar o solo para se obter água potável; avalia as correções do terreno.

4. A colocação de um gráfico de limpeza pode afetar o desligamento de qualquer pessoa que esteja em desarmonia com os princípios da empresa, inclusive se for o sócio, como já aconteceu.

5. A radiestesia e ofeng shui também permitem avaliar o logotipo da empresa.

6. No indivíduo, define as energias no terreno físico que ocupa e que podem interferir sobre a pessoa e fornece dados que podem facilitar a tomada de decisão (por exemplo, é possível detectar a origem, o motivo e melhor tratamento, em termos percentuais, de uma doença).

7. No caso do ambiente, o efeito é mais sutil. Geralmente, os funcionários não sabem que estão sob esse efeito, apenas sentem-se mais confortáveis e certos conflitos são resolvidos sem atritos. 
8. Melhora o ambiente de trabalho e facilita o relacionamento e o crescimento.

9. Há um ajuste de sintonia no relacionamento entre as pessoas (fala-se francamente).

10. Favorece a aproximação de futuros funcionários, que passam a se interessar em trabalhar e vir para os quadros da empresa.

\subsubsection{Shiatsu}

1. O maior diferencial é a redução do índice de dor e desconforto durante a jornada de trabalho, além de controle do estresse e aumento da auto-estima. Uma das entrevistadas relata que, na empresa em que presta serviços, faz cerca de 650 atendimentos por mês. Na semana de saúde, são atendidas, inclusive, as vendedoras que trabalham externamente.

2. Outra entrevistada observa que a maioria dos programas não solicita à consultoria em shiatsu a validação de outros indicadores tradicionais, normalmente utilizados em QVT, tais como melhoria do clima, redução de conflitos, redução do absenteísmo, melhor desempenho, melhor relacionamento, redução de despesas associadas à saúde. Acredita que esse fato se dá por dois motivos principais: o primeiro, pela falta de preparo dos prestadores de serviço em gestão. São normalmente técnicos especializados no atendimento que não têm visão do negócio e de indicadores associados. De outro lado, também as empresas não vêem alguma relação mais complexa na prestação desse serviço, muitas vezes minimizando a técnica como uma atividade de relaxamento e não como um suporte ao diagnóstico, conforme ela tem trabalhado nos últimos tempos, utilizando um de seus clientes como case de estudo.

\subsubsection{Vantagens e desvantagens das práticas alternativas, quando comparadas às práticas tradicionais}

Os profissionais entrevistados, em sua ampla maioria, não refutam as ferramentas tradicionais. Para eles, as ferramentas alternativas existem de forma complementar e como apoio a essas práticas (Tabela 11). Alguns deles consideram que as ferramentas alternativas 
têm como positivo o fato de atuar no desempate, por exemplo, na seleção de pessoas. Outro aspecto salientado é que, em algumas ferramentas, como a grafologia, a astrologia e a numerologia, é desnecessário ter o candidato à frente do especialista, distintamente de outras práticas tradicionais.

As desvantagens apontadas relacionam-se, na maior parte, ao despreparo de muitos profissionais que estão no mercado, os quais se auto-intitulam especialistas, mas que não têm formação para atuar como tal. Aliado a isso, cita-se a baixa qualidade dos cursos de formação profissional. Em relação à prática em si, há desvantagem, como a inexistência de precisão nos resultados das ferramentas, levando ao descrédito no mercado. 
Quadro 8 - Vantagens/desvantagens das práticas alternativas quando comparada às práticas tradicionais

\begin{tabular}{|c|c|c|}
\hline Ferramenta & Vantagens & Desvantagem \\
\hline Aromaterapia & - Complementa as ferramentas tradicionais. & - Seleção criteriosa do especialista na ferramenta. \\
\hline Astrologia & $\begin{array}{l}\text { - É uma ferramenta a mais. Não pode ser a única. Oferece orientação sobre uma } \\
\text { situação atual ou futura. } \\
\text { - Indica o tempo em que se deve fazer ou não fazer. } \\
\text { - Desnecessária a presença do avaliado. } \\
\text { - Não é possível manipular esta ferramenta como ocorre com outras práticas. A seleção } \\
\text { é feita remotamente. Ela desempata. } \\
\text { - Em RH, é quase completa, porque substitui outros trabalhos em seleção. É possível } \\
\text { realizar uma seleção com astrologia, análise de currículo e entrevista. }\end{array}$ & $\begin{array}{l}\text { - Não é fácil precisar o fato na astrologia. Por exemplo: se o } \\
\text { mapa aponta problemas com empregados, não é possível definir } \\
\text { como isso vai acontecer. } \\
\text { - O descrédito e preconceito, pois foi considerada maldita na } \\
\text { Idade Média e, desde então, tenta-se resgatá-la. } \\
\text { - A quantidade de pessoas que afirmam conhecê-la. Houve uma } \\
\text { banalização do conhecimento. Falta seriedade. } \\
\text { - Dificuldade para implantar pois, em razão da falta de mais } \\
\text { experiências empresariais, ainda não se dispõe de metodologia. } \\
\text { Ausência de dados (local, data e/ou hora) inviabiliza a elaboração } \\
\text { de um mapa. }\end{array}$ \\
\hline Grafologia & $\begin{array}{l}\text { - Identifica aspectos que outras práticas não conseguem, como, por exemplo, tendência } \\
\text { à mentira, à agressividade, ao alcoolismo. Nesses casos, o profissional faz a sinalização, } \\
\text { mas não o diagnóstico. Ao mesmo tempo, verifica que o candidato não tem como se } \\
\text { defender. Ao se submeter a um exame, está em posição de inferioridade. Mesmo que } \\
\text { tente disfarçar a letra, no decorrer do texto, culmina por mostrar suas características } \\
\text { pessoais. } \\
\text { - Custo compensador; facilidade, simplicidade e rapidez de aplicação (qualquer pessoa } \\
\text { pode aplicá-lo em qualquer local, o que torna desnecessária a presença do especialista). }\end{array}$ & $\begin{array}{l}\text { - Não há formação de qualidade em grafologia, o que reduz muito } \\
\text { a qualidade do trabalho profissional. A formação correta é de um } \\
\text { ano, para quem já conhece a grafologia, e de dois anos, para quem } \\
\text { não conhece. } \\
\text { - Não há desvantagens nessa prática alternativa. As empresas } \\
\text { precisam escolher bem o profissional que vai aplicar e interpretar } \\
\text { a Avaliação Grafológica, pois, como em todas áreas, existem } \\
\text { pessoas desqualificadas e até inescrupulosas que se auto- } \\
\text { denominam grafólogos. } \\
\text { - Não possui ainda validação no Brasil e, por isso, perdem-se } \\
\text { oportunidades de trabalho. } \\
\text { - É um instrumento pouco explorado: poderia ser aplicado, por } \\
\text { exemplo, em hospitais, com pacientes no estágio pré-cirúrgico. O } \\
\text { laudo mostra o quanto a pessoa está ou não preparada } \\
\text { emocionalmente para a cirurgia. }\end{array}$ \\
\hline Musicoterapia & $\begin{array}{l}\text { Pode ser complementar, tanto em uma dinâmica de grupo inicial, quanto no preparo de } \\
\text { pessoas para uma palestra. }\end{array}$ & $\begin{array}{l}\text { - Pessoas que pouco conhecem música utilizam a prática de forma } \\
\text { inadequada. }\end{array}$ \\
\hline
\end{tabular}




\begin{tabular}{|c|c|c|}
\hline Ferramenta & Vantagens & Desvantagem \\
\hline Feng Shui & $\begin{array}{l}\text { - O trabalho é complementar, nunca entra como questionamento ou crítica às } \\
\text { ferramentas tradicionais. } \\
\text { - Trabalha com uma empresa de administração de condomínios que não quer ser } \\
\text { mencionada. Ela entra com o trabalho administrativo e a entrevistada com as energias. } \\
\text { Em um desses trabalhos, apenas dois de três prédios foram locados. Ela alterou a forma } \\
\text { energética do prédio e este foi alugado. } \\
\text { - Traz harmonia. } \\
\text { - Contribui para ativar a empresa. }\end{array}$ & $\begin{array}{l}\text { - Não pode ser totalmente holística e tampouco técnica. Há que se } \\
\text { ter equilíbrio, harmonia. } \\
\text { - Profissionais que denigrem o trabalho. Existem charlatães e } \\
\text { pessoas despreparadas que vão ao mercado e oferecem cursos e } \\
\text { serviços. Em nome do feng shui, muitas barbaridades estão } \\
\text { acontecendo. }\end{array}$ \\
\hline Numerologia & $\begin{array}{l}\text { - A numerologia vê o lado oculto das pessoas, além da aparência. } \\
\text { - Acessa o ser em sua totalidade: psíquico, mental, físico (saúde e espiritualidade). } \\
\text { - Não é necessária a presença do avaliado. }\end{array}$ & $\begin{array}{l}\text { - As empresas gostam e fazem. Não há desvantagem } \\
\text { - Quando o processo interior se expande até o campo físico } \\
\text { transformando-se em doença. Logo, cabe ao profissional de saúde } \\
\text { complementar a cura. }\end{array}$ \\
\hline Radiestesia & $\begin{array}{l}\text { - São complementares. A radiestesia vai um pouco além. A área recruta e seleciona e a } \\
\text { radiestesia classifica os melhores. } \\
\text { - O custo é mais baixo. } \\
\text { - Complementa a área de psicologia, que atua no aspecto comportamental, agindo em } \\
\text { todos os níveis energéticos. Um trabalho comportamental, por exemplo, pode levar à } \\
\text { demissão das pessoas que forem indicadas. Com a radiestesia, ocorre a auto-seleção (as } \\
\text { próprias pessoas se demitem, sem causar atrito e, por isso, sem deixar energia negativa } \\
\text { na empresa). } \\
\text { - Pode ajudar a selecionar problemas que a arquitetura não consegue resolver. Cita o } \\
\text { exemplo de um dos prédios que são de sua propriedade há dez anos. Os primeiros } \\
\text { quatro anos foram repletos de problemas. Ela foi então em busca de radiestesia. Após } \\
\text { o tratamento nas energias locais, o prédio foi alugado e assim permanece há seis anos. }\end{array}$ & $\begin{array}{l}\text { - Não há. Considera apenas a ausência de credibilidade no } \\
\text { trabalho, externado por pessoas oficialmente mas que, } \\
\text { oficiosamente, buscam profissionais de sua própria confiança. }\end{array}$ \\
\hline Shiatsu & $\begin{array}{l}\text { - Tratamento complementar e preventivo às terapias médicas tradicionais. As } \\
\text { informações são passadas com caráter preventivo, reconhecendo outra dinâmica no } \\
\text { paciente, como o cura-te a ti mesmo. } \\
\text { - Não há comparação. Nas técnicas de massoterapia, a abordagem conceitual é } \\
\text { diferente. A visão do atendimento normalmente é mais vinculada a uma atividade de } \\
\text { relaxamento do que a uma atividade de tratamento; o que é uma subutilização da } \\
\text { técnica. }\end{array}$ & $\begin{array}{l}\text { - A falta de informação e a descrença na área médica. } \\
\text { - A formação e as dificuldades de recrutamento e seleção, pois, } \\
\text { pelo próprio perfil, esses profissionais têm dificuldades de } \\
\text { adaptação ao meio organizacional. } \\
\text { - Distribuição do horário, difícil de ser conciliado pois se trabalha } \\
\text { em jornadas de até } 5 \text { horas/dia, de forma a evitar ou pelo menos } \\
\text { adiar as lesões pelo excesso de movimentos repetitivos. Em } \\
\text { termos organizacionais, não há comparações a não ser com o uso } \\
\text { de analgésicos/antiinflamatórios e fármacos associados }\end{array}$ \\
\hline
\end{tabular}




\subsubsection{Como as práticas alternativas são aplicadas}

\subsubsection{Astrologia}

Segundo os entrevistados, geralmente quem procura o especialista é o empresário e não os técnicos da área de RH, os quais são mais resistentes às práticas alternativas.

O que os move a esta busca é a necessidade de apoio à tomada de decisão ou à elaboração de seu planejamento estratégico.

O especialista solicita dados da empresa, como data de fundação, e dos sócios, como data, local e horário de nascimento. A partir daí, calcula os mapas das pessoas; da empresa e o mapa composto (cruzamento dos individuais e da empresa), analisa os dados e os apresenta ao cliente.

Astrologia/Cosmologia/I-ching - Uma das entrevistadas, que desenvolve trabalho regular em uma das empresas pesquisadas, relata que o presidente lhe propôs que realizasse assessoria semanal, além de previsões bimestrais e semestrais A empresa cedeu um secretário, que desenvolveu um programa informatizado, para acompanhar as previsões semanais por ela encaminhadas.

Seu trabalho consiste na elaboração de um calendário de reuniões da diretoria, pelo período de um ano, informando como está o quadro cósmico e eles procuram segui-lo. Associa o trabalho astrológico à cosmologia, ou o estudo das cores. Cada planeta tem uma cor que a ele se relaciona. Refere a entrevistada que, como o papa Gregório alterou o calendário mundial, durante a Idade Média, ela procura utilizar o calendário cosmológico.

Além disso, bimestralmente, ela encaminha, com dez dias de antecedência, a previsão astrológica. A empresa encarrega-se de adequar o trabalho e enviá-lo aos gestores.

Independentemente dessa situação, quando há uma reunião importante, fazem uma consulta específica. Existem casos em que a astrologia, por fazer previsão de grandes tendências, não 
consegue definir se uma negociação será positiva ou não. Nesses casos, utiliza o $i$-ching para confirmar a informação. Para tanto, centra-se e define uma pergunta precisa. Utiliza um cerimonial voltando-se para o Leste, concentra-se e joga as moedas. Em seguida, analisa os resultados. Informa que só joga o i-ching em dias favoráveis.

Às quintas-feiras, envia um relatório contendo o clima da semana.

Em RH, a astrologia é solicitada nos casos de seleção de chefias e gerentes, após uma préseleção com a radiestesia.

\subsubsection{Aromaterapia}

A prática é utilizada como tratamento complementar do ambiente, a partir de diagnóstico realizado por outras ferramentas, como, por exemplo, a radiestesia. $\mathrm{O}$ especialista identifica o aroma mais adequado para tratar o problema identificado e o borrifa no ambiente.

\subsubsection{Feng Shui}

Os especialistas entrevistados são adeptos de dois tipos de escola: a do chapéu negro e a da bússola.

Na escola de chapéu negro, o especialista conversa com o cliente para saber sua intenção e conhecer os problemas que o levaram a procurar apoio profissional. Em geral, é o executivo que procura apoio. Eventualmente, conversa com o diretor financeiro ou de RH. A partir da análise da planta baixa do imóvel e com sua leitura espacial, detecta o que pode estar contribuindo para o problema apresentado e propõe alternativas de tratamento como, por exemplo, a correção de posições no espaço, com a colocação de plantas, cores, cristais, espelhos, dentre outros objetos que proporcionem bem-estar e minimizem interferências, aumentando a produtividade.

O especialista que atua com a escola da bússola utiliza o mesmo procedimento, no que se refere aos problemas. O diferencial é que, além da planta baixa do imóvel, utiliza a bússola 
para efetuar as medições necessárias. Além disso, faz perguntas às pessoas sobre dados, como local de entrada e saída, data, local e horário de nascimento, etc. Com os dados, faz um estudo e retorna para uma reunião, na qual apresenta um relatório com as análises e propostas de melhorias no ambiente.

\subsubsection{Grafologia}

O examinador entrega ao examinando duas folhas de papel sulfite em branco e lhe solicita que elabore uma redação, com "letra cursiva", de tema livre, entre 15 e 20 linhas, utilizando uma caneta esferográfica azul ou preta. O candidato disporá de todo o tempo que desejar.

Observações importantes:

a) $\mathrm{O}$ examinando não pode escrever no verso da folha.

b) Não pode passar o texto a limpo, pois não é permitido fazer rascunho ${ }^{19}$.

c) Não é permitido fazer cópia de texto.

d) No final da redação, o examinando deve assinar seu próprio nome. O candidato deve redigir o texto em uma mesa com tampo liso, ou seja, de fórmica ou vidro.

Após o término da redação, em uma folha à parte, incluirá as seguintes informações, de preferência com letra tipográfica, para facilitar o entendimento: nome completo, data de nascimento, estado civil, escolaridade, cargo ou função.

No primeiro momento, não se costuma explicitar que se trata de um teste grafológico, mas, por uma questão ética, ao final do teste, a pessoa deve ser informada.

\footnotetext{
${ }^{19}$ Uma das entrevistadas aceita a elaboração de rascunho.
} 
Quando trabalha para empresas que se encarregam de aplicar o teste, o especialista informa ao responsável pela aplicação que, se esta não for feita corretamente, o resultado não será assertivo.

\subsubsection{Musicoterapia}

Em geral, a musicoterapia é utilizada em treinamentos empresariais. Para tanto, é feita uma reunião inicial com o cliente e, após ser inteirado do objetivo a que se propõe a capacitação, cria as músicas que potencializem esse objetivo. Por exemplo: colocar música em um treinamento de planejamento estratégico que remeta os participantes ao passado, não dá sintonia, uma vez que o desejo é pensar o futuro.

Outra aplicação dessa ferramenta é na seleção musical a ser transmitida no ambiente das organizações. Nesse caso, a escolha das músicas dependerá dos objetivos da área de trabalho (mais harmonia, concentração, dentre outros aspectos).

\subsubsection{Numerologia}

O entrevistado atende aos executivos em seu consultório. No caso de RH, não atua diretamente e sim através treinamento de pessoas em seus cursos que, posteriormente, aplicarão os conceitos nas empresas nas quais trabalham.

\subsubsection{Radiestesia}

No atendimento empresarial, utiliza-se a radiestesia como método de diagnóstico do ambiente, de sócios, dos diretores e empregados ou de um tema específico sugerido pelo cliente. O especialista procura, onde se encontra, o local (espaço físico) em que há desarmonia, sua origem, o motivo e o melhor tratamento, em termos percentuais. A partir dos tratamentos indicados, dá início à harmonização, utilizando as ferramentas apontadas como melhor tratamento, sejam elas gráficos radiônicos, feng shui, aromais, florais, etc. 
Um entrevistado relata que faz o mapeamento da empresa, através da radiestesia, identificando desequilíbrio ou influências negativas, a começar pelo terreno (água, minerais no sub-solo).

Outro trabalho desenvolvido relaciona-se à avaliação dos sócios e da empresa em sua capacidade de progressão e de expansão da estrutura atual. O trabalho apóia as definições sobre a necessidade de reestruturação e em qual departamento; define a capacidade de absorção e o tipo de desequilíbrio. .

O feng shui difere da radiestesia. Enquanto o primeiro tem por objetivo ordenar a circulação interna do espaço, a segunda encarrega-se de analisar o solo. O trabalho da radiestesia consiste em bloquear a energia negativa do solo e trazer a energia do universo, para que se misturem e façam uma construção positiva.

Segundo um dos entrevistados, em um prédio, quando se faz o trabalho no andar térreo, todas as pessoas dos andares acima são beneficiadas. Se, todavia, o trabalho é realizado em um andar acima, apenas aqueles que estão no andar e nos andares acima serão beneficiados. Conforme informou, quando há energia negativa, potencializam-se nas pessoas doenças como a leucemia ou o câncer.

Todas as atividades aqui descritas são realizadas com o auxílio de um pêndulo, feito geralmente em cristal, um dos instrumentos mais utilizados na radiestesia. Como se trata de um equipamento questionável, do ponto de vista de validade científica, uma vez que pode haver indução à resposta, uma das entrevistadas foi indagada sobre como lidar com essa possibilidade. A resposta é que o maior desafio do radiestesista é ter o domínio de si mesmo e de suas emoções, para manter a neutralidade. Quando há neutralidade, a resposta do pêndulo é mais precisa. Essa é uma das razões pelas quais, por exemplo, na área de seleção, tem contato apenas com a ficha do candidato.

Nesse sentido, informa que seu maior cliente inicia um processo com a emissão de uma ordem de serviço, para a contratação ou substituição de um empregado, que é encaminhada para uma empresa parceira. Esta faz o recrutamento e a seleção de algumas pessoas e envia o 
nome para a radiestesista. Esta tem o prazo de 24 horas para fazer a pesquisa e emitir o laudo, em qualquer dia ou horário que lhe for solicitado.

\subsubsection{Shiatsu}

A técnica terapêutica shitasu é trabalhada de duas formas, em atendimentos de 30 minutos, aproximadamente, realizados em maca, e atendimentos de 15 minutos, feitos em cadeira ergonômica. Os atendimentos são agendados com a participação da empresa no processo e, normalmente, são aplicados em salas reservadas exclusivamente para essa atividade, embora os casos expressos possam ser realizados em qualquer espaço físico

\subsubsection{Aceitação das práticas alternativas em empresas}

As respostas para essa questão não são conclusivas para todas as ferramentas. Alguns especialistas referem crescimento na demanda por clientes empresariais, outros referem recrudescimento. Há consenso entre os especialistas de que as buscas por práticas alternativas crescem quando a empresa está atravessando um período de crise; os sócios desejam abrir um novo negócio ou precisam tomar alguma decisão importante para a organização. Quando não há crise instaurada, a procura acontece por curiosidade, geralmente relacionada à indicação feita por uma pessoa amiga ou da família, ou através da mídia. Mas, em geral, o trabalho tem caráter sigiloso.

Salvo os especialistas que atuam com grafologia, os demais referem ser consultados, na maior parte das vezes, por diretores ou proprietários das organizações.

Quanto à aceitação do trabalho em si, as respostas foram variadas.

\subsubsection{Astrologia}

Uma entrevistada responde que, do final da década até o momento atual, a maioria das organizações que procuram astrologia a aceita. Para ela, quanto mais desafiador o mundo dos 
negócios, mais alternativas o empresário busca. Contudo, não percebe crescimento na demanda e sim retração, salvo nos atendimentos pessoais, para os quais não houve alteração, embora as pessoas não assumam que usam essa ferramenta. Um entrevistado acredita que aquelas organizações que não aceitam a astrologia, o fazem por preconceito.

Outra entrevistada refere problemas com os gerentes de RH, que se mostram mais resistentes. Outra, ainda, acredita que todas as empresas familiares nas quais quem manda é o dono, que é o presidente, buscam algum tipo de ferramenta alternativa. Alguns chegam mesmo a ter um pai-de-santo. Considera também que as multinacionais têm restrições a tais ferramentas porque precisam prestar contas à matriz.

\subsubsection{Aromaterapia/Essências Florais}

A entrevistada relata que seu contato é feito na diretoria. Nem sempre os funcionários ficam sabendo do trabalho, como se a direção receasse divulgar que a empresa está utilizando ferramentas não tradicionais (receiam o conceito de bruxaria, especialmente por parte dos empregados evangélicos). Contudo, os funcionários sentem seu reflexo e onde a especialista tem liberdade de circular, estes a procuram, particularmente para solicitar ajuda com aromas, florais, etc.

\subsubsection{Feng Shui}

Para uma entrevistada, o fato de ser chamada para o trabalho, já mostra que há disposição em aceitar a prática. Em geral, isso ocorre quando o cliente está com problemas e, na maior parte das vezes, relacionado ao aspecto financeiro.

No que tange ao porte da empresa, as respostas foram antagônicas: uma entrevistada relatou que há maior aceitação por parte de grandes empresas, enquanto outra relatou serem seus dirigentes os mais relutantes.

Segundo outra entrevistada, $90 \%$ dos clientes fazem tudo o que se pede em relação às mudanças no ambiente, de acordo com o feng shui. Destes, $50 \%$ dão retorno dos resultados, 
mas ela não tem como comprovar. As grandes corporações solicitam propostas, enquanto as de menor porte contratam o trabalho sem maiores burocracias. Os gerentes de RH são os mais relutantes, embora tenha clientes particulares que são dessa área, incluindo escritórios de headhunter.

\subsubsection{Grafologia}

A grafologia, dentre as ferramentas analisadas, foi a única utilizada em algumas das grandes corporações pesquisadas.

Segundo um dos entrevistados, a aceitação é muito boa, mesmo entre aquelas que escondem o fato, principalmente agora que o Conselho Regional de Psicologia (CRP) proibiu vários dos testes. Para outro, existem preconceitos quanto à aplicação desse instrumento. Muitos profissionais de $\mathrm{RH}$, consideram a grafologia como da área do esoterismo, apesar da farta bibliografia existente. Segundo o especialista, após uma abordagem dos profissionais céticos, divulgando a eficácia do instrumento, e somente após conhecerem o processo, dificilmente eles deixam de utilizá-lo embora, inicialmente, a implantação seja delicada e suscetível a críticas.

Outro entrevistado refere não encontrar objeção: nas pequenas empresas onde atua como prestador de serviços, é a única pessoa de RH;, nas demais empresas, atua por indicação de outros. As multinacionais européias têm uma abertura ainda maior, pois lá a grafologia tem maior reconhecimento.

\subsubsection{Musicoterapia}

O entrevistado relata que não tem qualquer dificuldade nas empresas e sua agenda está sempre lotada. 


\subsubsection{Numerologia}

Dois dos entrevistados ressaltam o caráter sigiloso do seu trabalho: "ainda existem recusas nos moldes empresariais, no entanto os mesmos empresários buscam a numerologia nos moldes individuais".

Outro entrevistado relata que não vai à empresas oferecer o trabalho: os dirigentes o procuram e só então ele vai às empresas. Em muitos casos, trabalha com pessoas das empresas, mediante cursos, que ministra com freqüência.

\subsubsection{Radiestesia}

Para os entrevistados, a aceitação é total; tanto é assim que a demanda das empresas é crescente. Relata um deles que faz apenas um atendimento individual por dia, pois o investimento maior é na prestação de serviços para empresas.

Outro entrevistado conta que os gerentes que se rebelam, após um tempo, têm um motivo oculto que não queriam revelar. De modo geral, estes terminam por se auto-excluir (desligar) da empresa.

\subsubsection{Shiatsu}

Tem ampla aceitação. Uma especialista relata que o trabalho que realiza foi implantado pela própria empresa, que lhe destinou um espaço físico,e que é elevada a freqüência às sessões. Outra especialista, além de obter excelentes resultados na pesquisa de satisfação de seus serviços, refere que tem mantido e renovado os contratos para prestação de serviços. 


\subsubsection{Relação entre visão de mundo/sociedade, valores organizacionais e a aceitação/utilização de práticas alternativas}

A maior parte dos entrevistados considera que existe uma relação entre valores organizacionais e a aceitação/utilização de ferramentas alternativas. O que muda, contudo, é a forma como essa relação ocorre.

\subsubsection{Astrologia}

As respostas dentre esses especialistas foram distintas entre si. Uma entrevistada acredita que existe uma relação, uma vez que quem faz o mapa geralmente está em crise, mas apresenta uma configuração astrológica que lhe permite procurar apoio por meio de uma ferramenta alternativa.

Um entrevistado não sabe responder, uma vez que recebe pessoas mais conservadoras procurando a astrologia, mas com dificuldade para se expor. As que encaram o mundo de forma mais aberta, não se importam em colocar seus valores.

O terceiro entrevistado considera que existem três grupos de pessoas/organizações: o primeiro, de pessoas que têm uma visão holística e tendem a ter bons resultados. O segundo grupo, que define como de desesperados, é constituído de pessoas falidas, que estão em busca de ajuda. O terceiro grupo é de pessoas pragmáticas e, para ele, são as que apresentam melhor resultado, pois só aceitam a astrologia depois de verificar seus resultados.

Uma entrevistada ainda considera que os valores da empresa são retratados pela visão de mundo do presidente. A maior parte deles começa a utilizar tais ferramentas como mais um instrumento de decisão. Alguns, com pouco conhecimento, buscam um pai-de-santo para se proteger da inveja. Outros, com mais consciência, não se defendem de energias e, sim, buscam se fortalecer e, com isso, ampliam sua consciência, em termos de energias. 


\subsubsection{Aromaterapia/Essências Florais}

Para o entrevistado, existe esta relação, haja vista os problemas que encontra nas empresas com relação a pessoas que professam religiões evangélicas.

\subsubsection{Feng-Shui}

Dois dos três entrevistados responderam que sim. A relação está pautada na nova visão de integração homem x empresa; dos conceitos de compartilhamento, de inter-relacionamento, de autoconhecimento., de troca afetiva.

Um dos entrevistados respondeu que não. Para ele, normalmente, a empresa está mais preocupada com o resultado do balanço, em como materializar os seus resultados do que com as energias que estão interferindo para o alcance dos objetivos.

\subsubsection{Grafologia}

Um dos especialistas respondeu que sim e dois que não. A explicação para a nãoconcordância é que, no caso da grafologia, não há relação, porque ela começou com empresas européias que já utilizam grafologia desde os anos 50, principalmente as indústrias farmacêuticas.

Os especialistas que acreditam existir relação, justificam:

a) Com a utilização da grafologia, é possível adequar o perfil do profissional analisado, mostrando-lhe a necessidade de melhorar ou aprimorar seus talentos e conhecimentos. Ressaltam que a utilização dessa ferramenta não implicará a reprovação do candidato, no caso de uma seleção de pessoal, que só é eliminado caso o perfil mostre-se inadequado para o cargo a que está concorrendo. Cita como exemplo a empresa que necessita de um executivo para atuar numa diretoria financeira e cuja análise grafológica mostre ser, o profissional, dinâmico, participativo, mas indiscreto e volúvel; neste caso, o candidato estará contra- 
indicado, pela indiscrição apresentada, aspecto incompatível para quem exerce uma função gerencial na área financeira.

b) As razões estão relacionadas à cultura da organização (empresas européias a utilizam em suas matrizes) ou à solicitação do executivo principal, que teve contato com a ferramenta e apóia sua implantação na área de RH.

\subsubsection{Musicoterapia}

Para o entrevistado, nem toda empresa aceita esse tipo de trabalho, mas quando utiliza e o faz com responsabilidade, a relação existe.

\subsubsection{Numerologia}

Os entrevistados estabelecem uma relação entre valores e essa ferramenta. Um deles acredita que as características e valores das pessoas e da empresa que o contrata estão relacionadas. Cita como exemplo uma empresa na qual, após uma palestra que proferiu para os empregados, os sócios resolveram mudar o refeitório, criando um espaço de lazer.

Para outro entrevistado, a relação entre a utilização de ferramentas se estabelece quando comparada aos valores dos dirigentes e não das empresas, porque estas continuam as mesmas. São os gestores que buscam utilizar ou não a numerologia como ferramenta de trabalho.

\subsubsection{Radiestesia}

Os entrevistados assinalam que a aceitação dessa ferramenta tem acontecido por indicação positiva de outras pessoas ou organizações. Normalmente, quem indica já passou pelo processo individualmente ou conhece alguém que passou pela experiência e foi positiva. Costumeiramente, quem procura pelos especialistas é o dono da empresa. Os especialistas referem trabalhar apenas por indicação de outras empresas, sem nunca terem publicado 
anúncio. Um dos entrevistados acredita que a premissa para esses empresários é que o trabalho funciona, e se funciona para uma empresa deve funcionar para outra.

\subsubsection{Shiatsu}

Embora na maioria das empresas a escolha da prática alternativa se dê pela iniciativa de alguns, os valores, a missão, acabam contribuindo para a utilização. De toda forma, a aceitação se dá mais pela melhora do corpo físico, com a redução dos sintomas que levaram à procura do shiatsu (dor, rigidez, gastrite, insônia, estresse, fibromialgia e até depressão), do que à relação com a cultura organizacional.

\subsubsection{Aceitação ou discordância dos empregados}

A maior parte dos entrevistados informa que os empregados não ficam sabendo que a empresa utiliza ferramentas alternativas. A aceitação por causa de problemas religiosos, para algumas dessas práticas, foi enfatizada.

\subsubsection{Astrologia}

Dois dos entrevistados referem que a maior parte dos empregados aceita a ferramenta. Um deles refere utilizar a astrologia no mapa de sua própria empresa. Não contratava ninguém sem antes fazer o mapa astrológico. Fez isso, também, com pessoas de sua equipe (estagiários e arquitetos). Normalmente, as pessoas fornecem os dados. A maioria aceita pois, de início, a astrologia sempre gera interesse. Contudo, há um número pequeno que não aceita.

Outra entrevistada relata que na empresa em que está prestando serviços o empresário contou a todos os empregados.

Um entrevistado, respondeu que, de modo geral, os empregados não ficam sabendo que a empresa fez uso dessa prática. 
Uma entrevistada ainda refere não saber afirmar, pois é o presidente quem quer e, em decorrência, é possível que todos aceitem. Nesse caso, a prática incorporou-se à cultura da empresa.

\subsubsection{Aromaterapia/Essências Florais}

Para o especialista, o problema é a consciência. Muitos não têm acesso à informação e desconhecem essas ferramentas e seus benefícios. Cria-se uma atmosfera de misticismo, de uso de "forças ocultas" e receio pelo desconhecido. Quando esclarecido, há simpatia, apoio e interesse. Uma exceção é quando se esbarra nos preconceitos da religiosidade, observados de forma mais evidente em evangélicos e em católicos mais conservadores.

\subsubsection{Feng shui}

Um especialista refere que os problemas que encontra são sempre ligados à religião pois, a depender da crença do empregado, há rejeição.

Outro entrevistado considera que quem precisa saber sobre a aplicação dessa ferramenta é o gerente, que toma decisões. Considera desnecessário expor o programa a todos os empregados, salvo nos casos em que este é quem pede ajuda.

Outro entrevistado informa que, em empresas de maior porte, não se fala sobre o assunto. Em empresas de pequeno porte, ele já ministrou palestra para os empregados ou expôs vivências em treinamento de feng shui.

\subsubsection{Grafologia}

Para um entrevistado, a maioria dos empregados não sabe, não tem percepção exata, nem defesa contra a grafologia. Quando o candidato não é aprovado, fica com restrições em relação a essa ferramenta. Nos casos de aprovação, quando há feedback ao empregado, a 
aprovação é superior a 80\%. Contudo, o entrevistado tem dúvidas se a aceitação do feedback não é passiva. Se houver passividade, isso não significa uma aceitação.

Para outro entrevistado, geralmente, a avaliação grafológica de um profissional objetiva promover seu crescimento dentro da empresa e o resultado costuma satisfazer às suas expectativas. O empregado sente-se valorizado pela oportunidade de potencializar seus talentos gerando, em muitos casos, um rápido e produtivo retorno para sua empresa. Embora desconfiado a princípio, dificilmente o profissional avaliado criará resistências para se submeter ao instrumento.

Outro entrevistado considera que há aceitação por parte dos gerentes que são empregados e são eles que contratam esse serviço de consultoria.

\subsubsection{Musicoterapia}

Há aceitação. A arte é saudável e sua característica particular é fazer com que as pessoas se envolvam e toquem algum instrumento. Isso provoca encantamento por parte de quem participa do trabalho.

\subsubsection{Numerologia}

Para os entrevistados, o empregado aceita quando as empresas são éticas e dizem que utilizam a prática e, ainda, pela identificação de suas próprias características, o que lhe proporciona chances de correção.

\subsubsection{Radiestesia}

Um especialista respondeu que a maioria dos empregados não sabe que o trabalho está sendo realizado. Entre os que sabem, a aceitação e o respeito são totais. 
Outro especialista ressaltou que há discordância. Os gerentes de uma das empresas onde atua não queriam aceitar as regras impostas pelos donos. No caso, houve imposição.

\subsubsection{Shiatsu}

O trabalho é mais utilizado por empregados que realizam atividades administrativas do que por aqueles incumbidos das atividades operacionais. Na semana da saúde, como o trabalho é realizado também nos turnos, todos podem participar. Por outro lado, a falta de informação e a existência de profissionais pouco qualificados no mercado são fatores restritivos.

A outra entrevistada relata que a aceitação nas empresas é superior a $90 \%$.

\subsubsection{Relação entre a utilização de práticas alternativas e a motivação dos empregados}

A maior parte dos entrevistados acredita que as pessoas tendem a se motivar, com a utilização de ferramentas alternativas.

\subsubsection{Astrologia}

Há consenso entre os especialistas sobre a relação entre a utilização desta ferramenta alternativa e a motivação dos empregados. Um deles explica que o mapa da empresa diz qual o estilo dos empregados da empresa e, com isso, contribui para que esta direcione seu foco, de acordo com os empregados. Outro relata que em uma pesquisa com os empregados de uma empresa de canal a cabo, sobre temas de interesse dos empregados, a astrologia vocacional foi a vencedora, razão pela qual ele foi contratado para ministrar a palestra sobre esse tema. Outra,.ainda, relata que elabora mapa astrológico para uma empresa e que, quando o dia é negativo, os empregados ficam atentos e tomam mais cuidado para evitar os problemas apontados pelo mapa. 


\subsubsection{Aromaterapia/Essências Florais}

Quando os empregados percebem que há uma melhoria no ambiente e nas relações e que a empresa está zelando, tendo cuidado com eles, passam a querer bem àquela empresa e a zelar por sua permanência, oferecendo o melhor.

\subsubsection{Feng Shui}

Há consenso entre os especialistas quanto à relação entre essa ferramenta alternativa e a motivação dos empregados. Um entrevistado mensura essa alteração em função do retorno dos empregados, quando começa e quando termina o processo; quando todos sabem o que está acontecendo, geralmente em pequenas empresas. Outro entrevistado relata as mudanças verificadas pelas chefias de um call-center, com o reposicionamento de espelhos; e, em uma loja de móveis, a demora até acontecer o equilíbrio; além dos resultados obtidos em uma empresa de postos de gasolina.

\subsubsection{Grafologia}

Para um entrevistado, a relação existe, na medida em que o profissional se sente valorizado e busca o autoconhecimento, melhorando suas deficiências.

Para outro, a relação é indireta, porque possibilita que a organização contrate o candidato com perfil para a função, além de identificar, através da grafologia, se o candidato está motivado ou não.

Outro entrevistado considera que, para o gerente, do ponto de vista do empregado, a relação existe. Quanto aos empregados, de forma geral, não possui dados para informar. 


\subsubsection{Musicoterapia}

Para o especialista, esta ferramenta consegue criar estímulos para que a pessoa se automotive, na medida em que o empregado se sente respeitado, ao ouvir a música que gosta, há empatia com a empresa.

\subsubsection{Numerologia}

Os entrevistados consideram que sim, pois, além da possibilidade de conhecer seu próprio potencial, as pessoas sentem a importância delas para a empresa.

\subsubsection{Radiestesia}

Os entrevistados consideram que há relação. A finalidade da radiestesia é proporcionar o bem coletivo global. As pessoas ficam automaticamente mais motivadas, embora não tenham a exata noção do que acontece. Uma entrevistada relata que, em determinada empresa, a harmonia no ambiente melhorou, até mesmo em decorrência da mudança de atitude do próprio presidente.

\subsubsection{Shiatsu}

As terapias alternativas estão captando muitas pessoas no sentido amplo do termo. O conhecimento do Eu Superior, ou seja, da própria essência, acarreta maior aceitação das dificuldades, transformando as falhas das pessoas em virtudes. Refere que uma pessoa mais "espiritualizada" para o sentido da vida, é mais feliz.

Para outra especialista, a motivação está relacionada ao sentimento de valorização do empregado; ao reconhecimento, pela empresa, "de suas dores" e também da oportunidade de partilhar esse "sofrimento", solitário na fantasia, com os membros da equipe, da organização, em todos os níveis. 


\subsubsection{Relação entre a utilização de práticas alternativas e a qualidade de vida no trabalho}

A qualidade de vida no trabalho melhora, segundo os entrevistados, com a utilização das ferramentas alternativas analisadas.

\subsubsection{Astrologia}

O mapa da empresa indica qual é o estilo dela e qual é o de seus empregados (mais criativo, mais batalhador, dentre outras características), o que permite uma comparação e a adequação dos perfis. Além disso, com o apoio de outras ferramentas alternativas como, por exemplo, a medicina aiurvédica, é possível identificar o que deve ser colocado em uma sala de descompressão, para que esta atinja de fato os seus objetivos. Por fim, facilita a orientação profissional da pessoa na função que exerce.

Uma entrevistada sugere ministrar palestras para os empregados.

\subsubsection{Aromaterapia/Essências Florais}

A entrevistada acredita que esta relação existe: tanto assim que funcionários de um hotel, por exemplo, indicam o trabalho dela aos hóspedes por ouvirem comentários sobre o resultado obtido por outros que se submeteram ao tratamento. Há também aqueles que se sentiram beneficiados, como, por exemplo, uma monitora, que sempre adoecia nas temporadas e que melhorou com uma simples correção da rede Hathman, localizada na cabeceira de sua cama. Outra faz questão de auxiliar na limpeza dos cristais, para manter a harmonia do ambiente em que o especialista trabalhou, pois este nem sempre pode estar lá. Há também aquele que procura sempre informar ao especialista quando o aroma em estoque não chegará até a próxima visita dele. Há também aqueles que sentem maior proximidade e a procuram, em particular para pedir apoio pessoal em aroma, floral, etc. 


\subsubsection{Feng Shui}

Há consenso quanto à existência dessa relação. Para um entrevistado, quando o ambiente é energizado, uma das conseqüências é a melhora na qualidade de vida das pessoas que ali convivem. Em casos mais radicais, ele chega a sugerir até mesmo a mudança de prédio.

\subsubsection{Grafologia}

Dois entrevistados responderam que sim, pois esse instrumento objetiva a melhoria da qualidade operacional, na medida em que direciona o candidato para a atividade que o torne mais satisfeito. O próprio exame não leva o candidato a um estresse, pois lhe é solicitado que redija uma redação com tema livre.

Outro acredita que não diretamente. Indiretamente, quando há uma melhor seleção para o cargo, o resultado é a redução de problemas no emprego.

\subsubsection{Musicoterapia}

A relação é total. Para o entrevistado, nem sempre é agradável trabalhar oito horas por dia em um escritório. No entanto, quando se coloca arte no ambiente, o local torna-se mais agradável.

\subsubsection{Numerologia}

Existe a relação, tanto que um entrevistado está sendo contratado para dar palestras sobre motivação, em um banco estatal. Para outro entrevistado, tanto a numerologia quanto o feng shui prescrevem uma adaptação à função; uma postura correta; a segurança e a confiança de conhecer o seu momento; a capacidade de flexibilização ou não; e a facilidade para administrar suas próprias reações. 


\subsubsection{Radiestesia}

Para os entrevistados, há relação. Segundo um deles, tende a melhorar a qualidade de vida no trabalho pois, dependendo da análise que faz, sugere inclusive mudanças no local de trabalho. Outro entrevistado ressalta que a área de RH não utiliza diretamente, pois, de modo geral, quem solicita seus serviços são os donos ou sócios específicos, como é o caso de uma intervenção que está realizando em um shopping center.

\subsubsection{Shiatsu}

A intervenção é atrelada ao programa de QVT e/ou à saúde ocupacional e à prevenção de doenças relacionadas ao trabalho. As práticas são associadas e escolhidas por suas características menos invasivas e sem contra-indicação, para grandes grupos. Não há vinculação direta com a gestão e os indicadores ainda são incipientes para a validação delas.

\subsubsection{Análise complementar de dados coletados com os especialistas}

Embora os dados coletados não possam confirmar a tendência, verificou-se, na astrologia, a atuação de profissionais cuja formação primeira é na área de engenharia. De quatro entrevistados, três foram motivados a utilizá-la, atraídos pelo fato da ferramenta necessitar de cálculos prévios para a análise. As demais práticas pesquisadas não apresentaram preponderância de alguma área específica de formação.

Observou-se, ainda, que os profissionais que utilizam grafologia, de modo geral, são especializados apenas nesta ferramenta. Um dos entrevistados, inclusive, salientou que não a considera uma ferramenta alternativa, uma vez que é muito utilizada em países europeus.

\subsection{As práticas alternativas na visão dos gestores das empresas pesquisadas}

Foram analisadas 11 empresas que utilizam uma ou mais práticas alternativas. A pesquisa consistiu em entrevista com o proprietário da empresa ou o gestor responsável pelo uso da 
ferramenta. Como são empresas completamente diferenciadas, tanto no tamanho quanto na área de atuação, optou-se por apresentar os dados coletados individualmente. Além disso, como nem todas as empresas desejavam ter seus nomes explicitados no estudo, optou-se por identificá-las por um número.

\subsubsection{Perfil dos gestores entrevistados e das práticas utilizadas}

O fato de as empresas que participaram do estudo não terem sido escolhidas por amostragem, inviabiliza a análise sob o ponto de vista do porte. De toda forma, foram objetos de estudo organizações de pequeno a grande porte, com predominância para as de médio porte (Gráficos 9 e 10).

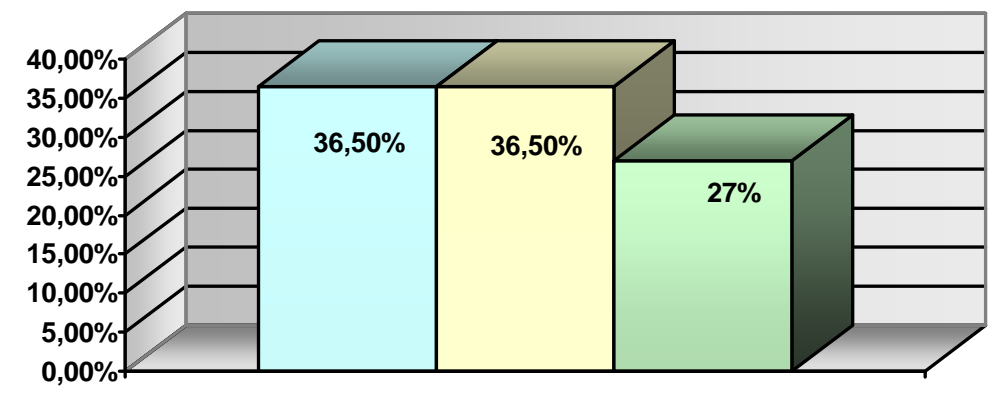

$\square$ Pequeno

$\square$ Médio

$\square$ Grande

Gráfico 9 - Empresas divididas por porte

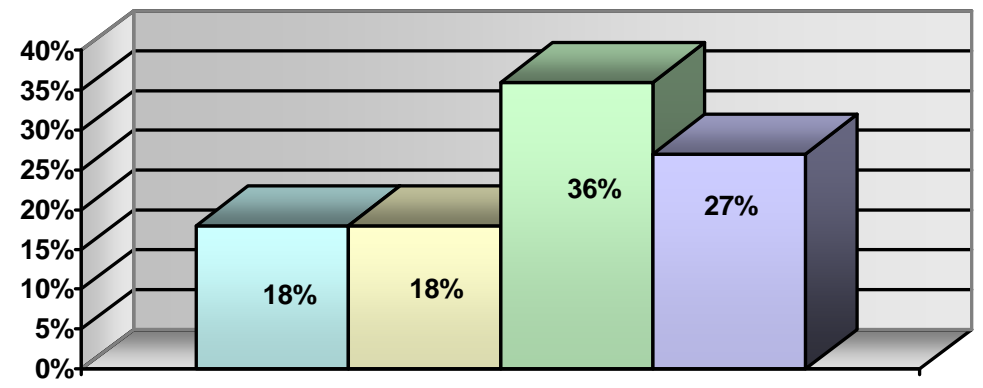

$\square$ Até 20 $\square$ De 21 a 100 $\square$ De 101 a 500 $\square$ Acima de 500

Gráfico 10 - Empresas agrupadas por número de empregados

Foi possível verificar que as empresas de grande porte tendem a aceitar as práticas menos relacionadas a perspectivas esotéricas, como é o caso da grafologia, shiatsu, tai chi chuan e 
ioga. Este aspecto reforça a tendência verificada no levantamento quantitativo de que a grafologia, embora não seja reconhecida oficialmente no Brasil, tem maior aceitação do que as demais práticas aqui analisadas. Seu uso, contudo, não se restringe às grandes corporações, uma vez que foram identificadas empresas de pequeno e médio portes que empregam essa ferramenta (Tabela 5).

Tabela 5 - Prática alternativa por porte de empresa

\begin{tabular}{|l|c|c|c|}
\hline Ferramenta & Pequeno porte & Médio porte & Grande porte \\
\hline Astrologia & 3 & 1 & \\
\hline Espiritualismo & & 1 & \\
\hline Feng shui & & 3 & \\
\hline Grafologia & 2 & 1 & 2 \\
\hline Numerologia & 2 & 1 & \\
\hline Radiestesia & & 3 & 1 \\
\hline Shiatsu & & & 1 \\
\hline Tai chi chuan & & & 1 \\
\hline Tarô & 1 & & \\
\hline Ioga & & & \\
\hline
\end{tabular}

No que tange à faixa etária, os gestores entrevistados têm mais de 40 anos (Gráfico 11), atuam há mais de cinco anos na organização (Gráfico 12) e a maior parte possui nível superior completo e pós-graduação (Gráfico 13). A maioria constitui-se de proprietários ou de pessoas que ocupam cargos diretivos (Gráfico 14).

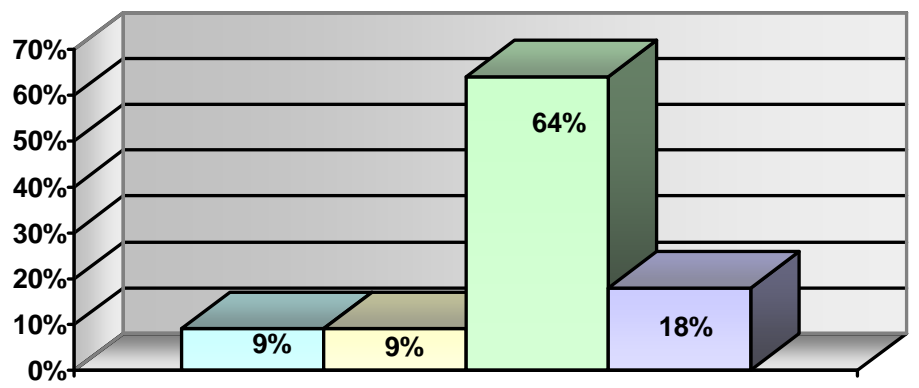




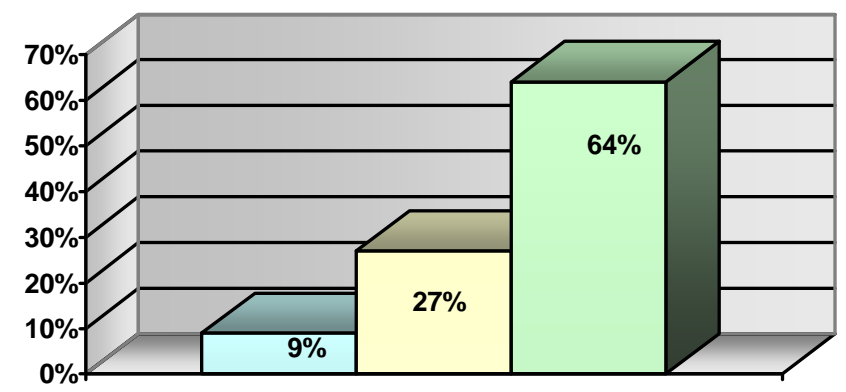

Gráfico 12 - Tempo de atuação na empresa

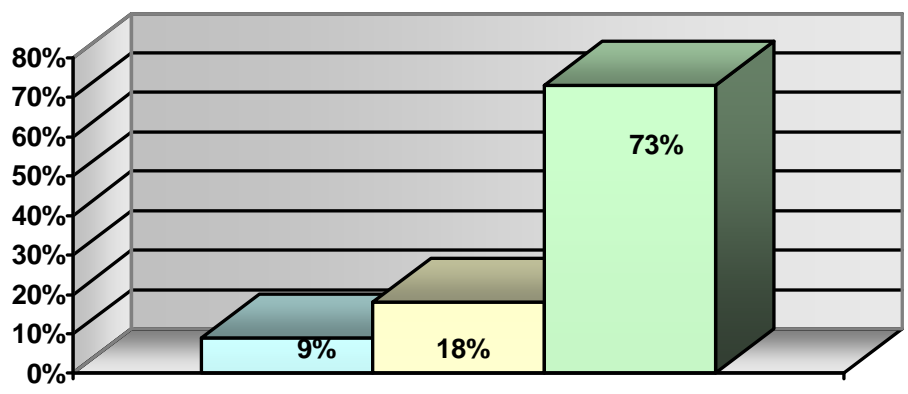

Gráfico 13 - Formação escolar

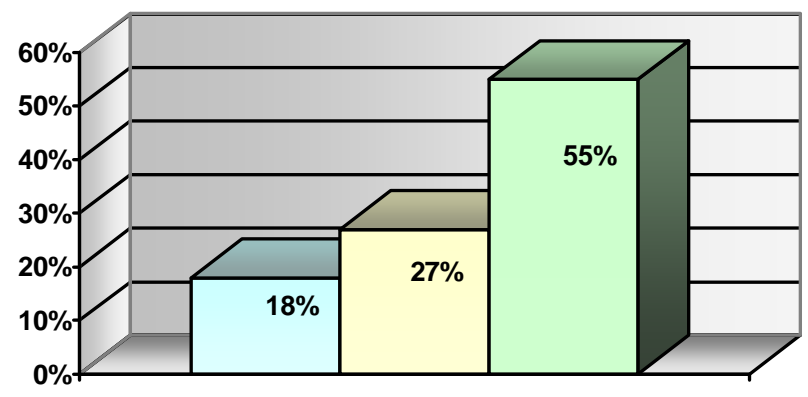

\section{Gráfico 14 - Nível hierárquico dos respondentes}

Das práticas pesquisadas, destacam-se a grafologia, a astrologia, o feng shui e a radiestesia, utilizadas rotineiramente em mais de uma empresa. Ferramentas como a numerologia e o tarô são empregadas apenas quando necessário (Tabela 6). As áreas de gestão de pessoas que mais utilizam essas práticas são as de Recrutamento e Seleção, e Saúde Ocupacional/QVT. 
Constatou-se, ainda, que dirigentes de algumas dessas empresas utilizam tais práticas como apoio e aconselhamento em seus processos de tomada de decisão (Tabela 7). A descrição de cada caso está contida no próximo tópico.

Tabela 6 - Freqüência de utilização das práticas

\begin{tabular}{|l|c|c|c|}
\hline \multirow{2}{*}{ Ferramenta } & \multicolumn{3}{|c|}{ Freqüência } \\
\cline { 2 - 4 } & Apenas uma vez & $\begin{array}{l}\text { Algumas vezes } \\
\text { Sempre que necessário }\end{array}$ & Rotineiramente \\
\hline Grafologia & & 2 & 3 \\
\hline Astrologia & & & 4 \\
\hline Numerologia & 2 & 1 & 2 \\
\hline Tarô & & 1 & 2 \\
\hline Feng shui & & & 1 \\
\hline Radiestesia & 1 & & 1 \\
\hline Shiatsu & & & 1 \\
\hline Ioga & & & 1 \\
\hline Tai Chi Chuan & & & \\
\hline Espiritualismo & & & \\
\hline
\end{tabular}

Tabela 7- Áreas que utilizam as práticas alternativas

\begin{tabular}{|c|c|c|c|c|c|c|c|}
\hline Ferramenta & $\begin{array}{l}\text { Recruta } \\
\text { - mento e } \\
\text { Seleção }\end{array}$ & $\begin{array}{c}\text { Avaliação } \\
\text { de } \\
\text { Desem- } \\
\text { penho }\end{array}$ & $\begin{array}{l}\text { Aconselha- } \\
\text { mento }\end{array}$ & Gestão & $\begin{array}{c}\text { Proces- } \\
\text { sos de } \\
\text { Promo- } \\
\text { ção }\end{array}$ & $\begin{array}{l}\text { Razão } \\
\text { Social }\end{array}$ & $\begin{array}{l}\text { QVT/Saúde } \\
\text { Ocupacional }\end{array}$ \\
\hline Astrologia & 4 & 1 & 1 & 1 & & & \\
\hline Espiritualismo & & & & 1 & & & \\
\hline Feng shui & & & & & & & 3 \\
\hline Grafologia & 5 & 1 & 1 & & 1 & & \\
\hline Numerologia & & & & 2 & & 1 & \\
\hline Radiestesia & 1 & & & 2 & & & 1 \\
\hline Shiatsu & & & & & & & 1 \\
\hline Tai chi chuan & & & & & & & 1 \\
\hline Tarô & & & 1 & & & & \\
\hline Ioga & & & & & & & 1 \\
\hline
\end{tabular}




\subsubsection{Descrição dos casos pesquisados}

\subsubsection{Empresa 1}

\begin{tabular}{|l|l|}
\hline \multicolumn{2}{|c|}{ Identificação } \\
\hline Ramo & Embalagens \\
\hline Porte & Médio \\
\hline Número de empregados & 604 \\
\hline Faixa etária do entrevistado & 30 a 39 anos \\
\hline Tempo de atuação na empresa & Mais de cinco anos \\
\hline Formação escolar & Pós-graduação \\
\hline Pessoa entrevistada & Chefe de Recrutamento e Seleção \\
\hline
\end{tabular}

Breve histórico - A empresa analisada existe há 58 anos. Iniciou suas atividades no bairro da Mooca, na cidade de São Paulo e, posteriormente, mudou-se para a cidade de São Bernardo do Campo, onde está instalada até hoje.

Multinacional americana, até o ano de 1991, quando a matriz optou por vender a empresa. Foi comprada por dois diretores da época, mediante financiamento bancário. A matriz facilitou a transferência e o empréstimo foi pago há cinco anos, entretanto a situação financeira não melhorou. Há três anos, a empresa está enfrentando sérias dificuldades, com problemas em seu fluxo de caixa.

No momento da entrevista (janeiro de 2005), a empresa funcionava precariamente, uma vez que os empregados, sem salário, optaram por não trabalhar. No dia anterior, a empresa permaneceu fechada e estava em vias de pedir concordata.

Momentos de Crise - Devido aos problemas de fluxo de caixa, este é o pior momento que a empresa está vivendo desde a sua criação.

Momento em que começou a utilizar a prática alternativa - Em 1999, o entrevistado fez um curso básico de grafologia e, desde então, vem aplicando seus conhecimentos. A análise grafológica é feita para candidatos a cargos de supervisão, de chefia e técnicos. Para os 
cargos de ajudante, mais operacionais, não é aplicada a análise grafológica. A decisão final sobre a admissão na empresa é do gerente.

\section{Práticas alternativas utilizadas na organização}

\begin{tabular}{|l|l|l|}
\hline \multicolumn{1}{|c|}{ Prática } & \multicolumn{1}{|c|}{ Freqüência } & \multicolumn{1}{c|}{ Áreas } \\
\hline Grafologia & Rotineiramente & Recrutamento e seleção \\
\hline
\end{tabular}

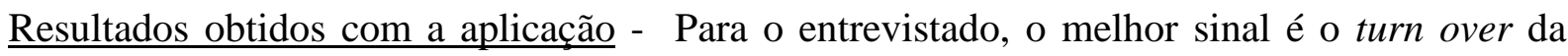
empresa, que é baixo. Em termos práticos, cita o exemplo de uma análise grafológica que detectou problemas de idoneidade do candidato. Foi em busca de informações adicionais e verificou que ele tivera problemas na empresa anterior, com furto. A decisão foi por não contratá-lo.

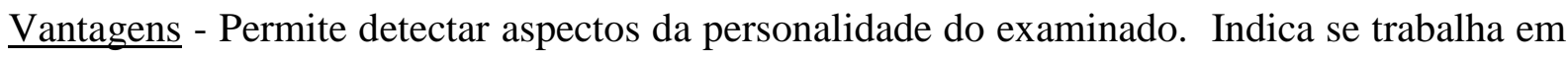
grupo, se é ou não individualista, dentre outros aspectos.

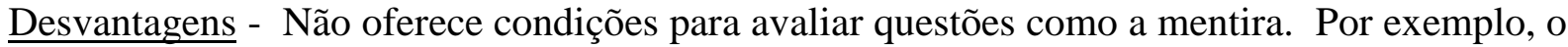
desespero pelo desemprego faz com que a pessoa infle seu currículo com informações sobre conhecimentos que, na verdade, não tem.

Como aplica a prática - As admissões na empresa ocorrem da seguinte forma:

1. Para os níveis básicos, ou seja, operacionais, verifica-se se o candidato reside na cidade de São Bernardo do Campo e faz-se um teste simples de português e matemática.

2. Para os níveis técnicos, faz-se análise de currículo e a grafológica. Em casos específicos, pede-se um laudo adicional de um psicólogo.

Para realizar a análise grafológica, o entrevistado entrega um papel sulfite, em branco, com caneta esferográfica. Pede ao candidato que redija um texto sobre um tema atual e o assine. Com o texto e a assinatura, faz a análise grafológica e emite o laudo. 
Aceitação do corpo gerencial - Dos oito gerentes da empresa, seis aceitam a prática e pedem para que seja aplicada e dois deles não a aceitam.

$\underline{\text { Relação entre a visão de mundo e de sociedade e dos valores propostos na organização e a }}$ aceitação/utilização de práticas alternativas - Para o entrevistado, não existe esta relação. A direção da empresa tem uma visão mais limitada da organização focada nos resultados. Não há percepção da grafologia com o sentido de valores mais abrangentes.

Aceitação/discordância por parte dos empregados - O candidato é informado de que se trata de um teste grafológico, mas somente quando o texto é concluído e ele o assina. O entrevistado informa que, em todas as aplicações que fez, somente dois candidatos o questionaram. De modo geral, ele não faz a devolutiva do laudo para quem se submeteu ao teste, mas os que questionaram o processo tiveram acesso ao laudo. Em ambos os casos, o índice de aceitação do laudo foi de $90 \%$ de acertos. Quando tem dúvidas sobre o laudo que está emitindo, procura a ajuda da profissional que ministrou o seu curso para que verifique possíveis erros de análise.

De toda forma, o teste grafológico não é eliminatório, no processo de seleção da empresa. A decisão final é de quem pediu a contratação.

Relação entre a utilização de práticas alternativas e motivação dos empregados - Não há, na empresa analisada, relação entre a aplicação de teste grafológico e a motivação dos empregados.

Relação entre a utilização de práticas alternativas e qualidade de vida no trabalho - Não há, na empresa analisada, qualquer relação entre a aplicação de teste grafológico e a qualidade de vida no trabalho. 


\subsubsection{Empresa 2}

\begin{tabular}{|l|l|}
\hline \multicolumn{2}{|c|}{ Identificação } \\
\hline Ramo & Farmacêutica \\
\hline Porte & Grande (multinacional) \\
\hline Número de empregados & 500 (Brasil) \\
\hline Faixa etária do entrevistado & 20 a 29 anos \\
\hline Tempo de atuação na empresa & Mais de cinco anos \\
\hline Formação escolar & Superior completo \\
\hline Pessoa entrevistada & Analista de Seleção e Treinamento Pleno \\
\hline
\end{tabular}

Breve histórico - A empresa é de origem holandesa e tem 80 anos. Está no Brasil há 65 anos. Possui aproximadamente 500 empregados, sendo 230 internos e 250 em campo. Há alguns anos, associou-se a um grupo de origem americana e, desde então, vem mudando sua filosofia, agora voltada para resultados. O grupo possui outras divisões (química e tintas), mas cada uma é autônoma no seu processo de gestão. O foco dos produtos está voltado à terapia humana, ao planejamento familiar, ao sistema nervoso central, investindo em pesquisa sobre anestesia. Hoje, a empresa tem duas matrizes: uma em New Jersey, Estados Unidos, e outra em Ozz, na Holanda.

Momentos de crise/oportunidade - A entrevistada foi admitida em 2000, momento em que o RH da empresa pleiteava mudanças, para sair da estrutura paternalista na qual se encontrava.

Nova crise aconteceu em 2003, quando ocorreu o lançamento de um medicamento, sem o retorno sobre o investimento esperado, diferentemente do que ocorrera na Europa e nos EUA . A empresa efetuou, então, 50 demissões, o que fez o clima piorar muito. De 2004 para cá, ocorreram ações para melhorar o clima e os índices de ambiência vêm melhorando. A mudança na mentalidade e na cultura organizacional, pleiteada em 2000, também vem se concretizando.

Momento em que começou a utilizar prática alternativa -_Como acontece a cada quatro anos, na empresa, houve troca de presidente no ano de 2001. O executivo que tomou posse era um português, que solicitou a inclusão de bateria de testes para admissão. Foi contratada uma consultoria, que propôs vários testes, dentre eles a grafologia. 
Práticas alternativas utilizadas na organização

\begin{tabular}{|l|l|l|}
\hline \multicolumn{1}{|c|}{ Prática } & \multicolumn{1}{|c|}{ Freqüiência } & \multicolumn{1}{c|}{ Área } \\
\hline Grafologia & Rotineiramente & Recrutamento e Seleção \\
\hline
\end{tabular}

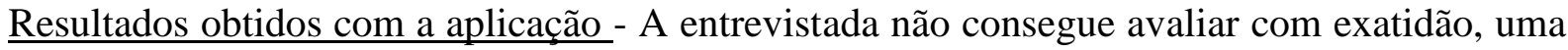
vez que a grafologia faz parte de uma bateria de testes, que são aplicados nos candidatos. Lembra apenas de um laudo que detectou perfil de agressividade. A empresa já pensou em aplicar os testes e realizar a análise internamente, por meio de seus próprios técnicos, mas eles são demorados, razão pela qual é feito por uma consultoria. Todos os empregados, exceto os operadores, são submetidos aos testes que incluem a grafologia.

Vantagens - Na seleção tradicional, o candidato olha para um psicólogo, que lhe aplica um teste pré-formatado e acredita que já tem todos os elementos para ser avaliado. Já com a grafologia, que pede a redação de um texto espontâneo, o candidato não sabe qual o fundamento da redação que escreverá.

Desvantagens - O teste não é preciso. É necessário ter grande expertise (ser especialista) em grafologia para emitir um bom laudo.

Como aplica essa prática - A empresa preocupa-se muito com questões éticas. Quando o candidato se submete a um teste, a empresa devolve o material, pois o resultado não lhe pertence e sim ao candidato.

De modo geral, a seleção é iniciada com a aplicação de alguns testes psicológicos. Depois, são oferecidos uma folha de papel sulfite e um lápis número dois e é pedido ao candidato que escreva um texto, com tema livre, em 20 linhas, destinado ao teste grafológico. Quando terminado esse teste, outros tipos são aplicados. Cabe à consultoria aplicar, analisar e emitir o laudo. A entrevistada desconhece detalhes sobre o processo de avaliação.

Aceitação do corpo gerencial - Os próprios gerentes da empresa foram submetidos a uma bateria de testes. Segundo a entrevistada, no início, foi complicado porque muitos ficaram com muito receio. Hoje, como quem os aplica divulga o objetivo, os testes tornaram-se 
normais na empresa. Os gerentes agora solicitam que a bateria de testes seja aplicada nos candidatos, pois estes assumiram e se comprometeram com o processo.

$\underline{\text { Relação entre a visão de mundo e de sociedade e dos valores propostos nesta organização e a }}$ aceitação/utilização de práticas alternativas - Não há relação. A direção da empresa tem uma visão mais limitada sobre esse processo na organização. Não há percepção da grafologia com o sentido de valores diferenciados.

Aceitação/discordância por parte dos empregados - Relata a entrevistada que, até hoje, nunca houve questionamento sobre essa temática. Os empregados têm curiosidade, embora considerem a bateria de testes difícil e longa. A duração é em média de quatro horas. Em geral, os testes são bem-vindos por todos e entendidos como uma oportunidade de melhoria.

Relação entre a utilização de práticas alternativas e motivação dos empregados - Não considera que exista relação entre motivação e a grafologia. Sua utilização é mais ligada ao processo de aprendizado, oportunidade de carreira e desempenho na função.

Relação entre a utilização de práticas alternativas e qualidade de vida no trabalho - Não vê a grafologia especificamente relacionada à qualidade de vida no trabalho. A empresa desenvolve outras atividades relacionadas à saúde, como é o caso da ginástica laboral.

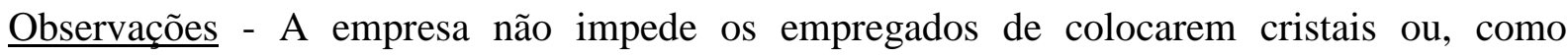
aconteceu com uma gerente, que realizou o feng shui em sua área, mas de forma isolada. Não é institucional. 


\subsubsection{Empresa 3}

\begin{tabular}{|l|l|}
\hline \multicolumn{2}{|c|}{ Identificação } \\
\hline Ramo & Hotelaria \\
\hline Porte & Pequeno \\
\hline Número de empregados & 75 \\
\hline Faixa etária do entrevistado & Mais de 50 anos \\
\hline Tempo de atuação na empresa & Mais de 5 anos \\
\hline Formação Escolar & Superior completo \\
\hline Pessoa entrevistada & Sócio diretor \\
\hline
\end{tabular}

Breve histórico da empresa - A empresa, em 2005, completa 25 anos. Tem hoje 75 empregados, entre regulares e temporários, contratados de acordo com as necessidades. $\mathrm{Na}$ primeira década, vivenciou uma fase de prosperidade e destaque em seu segmento (hotel de lazer), segundo o entrevistado, seja por ser uma novidade surgida em um ambiente provinciano e decadente, seja pela utilização de campanhas ousadas de divulgação do hotel, com procedimentos inéditos em um mercado conservador e amorfo, então vigente, e dependente da sazonalidade.

A partir da segunda década (1991/1992), a empresa sofreu os reveses de uma concorrência crescente, local e periférica, e, em alguns casos, até predatória; de uma especulação imobiliária desenfreada, que atraiu um público heterogêneo, fator de inibição da clientela tradicional. Além disso, verifica-se um envelhecimento das instalações do hotel, aliada a uma crônica escassez de recursos para investimentos na renovação e modernização do produto e uma perda acentuada do poder aquisitivo do mercado consumidor, dentre outras.

Atualmente, o hotel passa por um processo de revitalização e melhoramento (benfeitorias) de suas instalações e experimenta os efeitos da transição para uma nova fase de sua gestão administrativa.

Momentos de crise - Conforme explicitado anteriormente, a partir da segunda década de operação (1991/1992), até recentemente; os momentos de oportunidade ocorreram durante a primeira década (1980/1990) e foram desperdiçados, segundo o entrevistado, por negligência e "cegueira" empresarial; durante esse período, o comércio local encontrava-se em um estágio primitivo e a sociedade, tanto residente quanto flutuante, sentia-se carente da prestação de serviços especializados, tais como a organização de festas e eventos, reformas em geral, 
consultoria técnica de lazer. Etc. Nas palavras do entrevistado, vale o ditado popular: "Em terra de cego, quem tem um olho é rei!".

Momento em que começou a utilizar a prática alternativa - A empresa adotou o método há aproximadamente quatro anos (2001). Atualmente a utilização da ferramenta alternativa está suspensa, seja devido ao processo de transição da gestão administrativa, seja por conflitos de interpretação e atuação da gerência operacional.

$\underline{\text { Práticas alternativas utilizadas na organização }}$

\begin{tabular}{|l|l|l|}
\hline \multicolumn{1}{|c|}{ Prática } & \multicolumn{1}{|c|}{ Freqüência } & \multicolumn{1}{c|}{ Área } \\
\hline Grafologia & $\begin{array}{l}\text { Algumas vezes, por tempo } \\
\text { determinado }\end{array}$ & $\begin{array}{l}\text { Recrutamento e seleção } \\
\text { Aconselhamento } \\
\text { Avaliação de desempenho }\end{array}$ \\
\hline
\end{tabular}

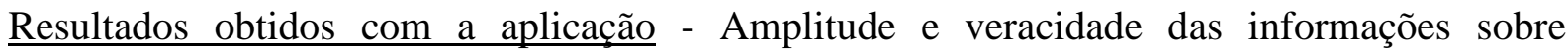
personalidade e caráter, do funcionário e/ou candidato avaliado.

Vantagens - Simplicidade e rapidez de aplicação do teste; ótimo custo/benefício; seriedade e confiabilidade nas informações sobre as características do funcionário avaliado.

Desvantagens - Para o entrevistado, ceticismo e desconfiança na eficácia da grafologia, tanto por se tratar de uma prática recente em relação aos métodos tradicionais já consagrados, quanto pela visão canhestra de profissionais conservadores e avessos a novas experimentações.

Como aplica essa prática - O entrevistado solicita que o analisando se sente confortavelmente; em seguida, entrega-lhe algumas folhas de papel sulfite em branco modelo "A4" além de uma caneta esferográfica e o orienta na elaboração de uma redação, com letra cursiva, contendo no mínimo 15 linhas e no máximo 25.

Adverte sobre o ineditismo do tema a ser desenvolvido, sugerindo abordar assunto sobre si próprio, até mesmo descrever algo de seu cotidiano ou relatar sob sua ótica algum acontecimento atual. Enfatiza a proibição de rascunho e, na ocorrência de um erro de grafia 
ou mudança de palavra ou frase, orienta ao analisando riscar o trecho em questão e prosseguir em sua escrita. Comunica que não é permitido escrever no verso da folha e solicita-lhe que assine ao final do texto, preferencialmente com a mesma assinatura que utiliza em documentos oficiais.

Após esses procedimentos, em uma folha à parte, registra o nome completo do profissional, em letra de fôrma; sua data de nascimento, estado civil, escolaridade; e, se candidato, o cargo ou função pleiteada.

Finalmente, encaminha o material para o(a) grafólogo(a) e aguarda o respectivo laudo.

Aceitação do corpo gerencial - Conforme informa o entrevistado, por se tratar de uma sociedade familiar de pequeno porte, o corpo gerencial resume-se a um único gerente geral e operacional; a aceitação da grafologia por esse gerente ficou comprometida, mesmo comprovada sua eficácia até em seu próprio laudo, pela resistência à inovação e pela insegurança em relação a eventuais manifestações imprevisíveis do corpo funcional sob o seu comando; segundo seu entendimento, funcionário que sabe demais se valoriza, fica exigente e pode ir embora ou até tornar-se um elemento ameaçador para a direção.

Observação - O corpo funcional é constituído por indivíduos de origem humilde, com baixa e média escolaridades, exceto o gerente e duas funcionárias que exercem cargos de chefia há vários anos.

$\underline{\text { Relação entre a visão de mundo e de sociedade e dos valores propostos nesta organização e a }}$ aceitação/utilização de práticas alternativas - A resposta do entrevistado não foi clara. Para ele, vivemos uma época de profundas transformações no processo evolutivo das relações trabalhistas, com ênfase na responsabilidade social (aqui relacionado ao ambiente interno da empresa) e na crescente integração entre dirigentes e subordinados, de forma a harmonizar a relação laboral e eliminar focos de atrito pela influência negativa de práticas sindicalistas anacrônicas sobre a massa trabalhadora. Ele lamenta que, em pleno século XXI, ainda haja posturas retrógradas quanto à utilização de práticas inovadoras, comprovadas e consagradas em grandes empresas do Primeiro Mundo (América do Norte, Europa ocidental e Japão). 
Aceitação/discordância por parte dos empregados - Os funcionários pouco se manifestam, porque receiam expressar opiniões que julgam inconsistentes. Mas, passada a desconfiança inicial de alguns, praticamente todos aceitam se submeter a testes que possam aprimorar a sua qualificação profissional e produtividade.

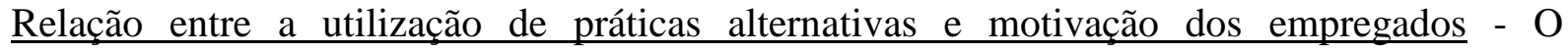
entrevistado acredita que se houvesse maior interesse em conhecer a grafologia, os funcionários se sentiriam motivados pelos resultados apresentados por esta ferramenta e estimulados a exercitar um processo de crescimento profissional, além de constatarem alternativas de solução no combate às suas deficiências de ordem pessoal e profissional.

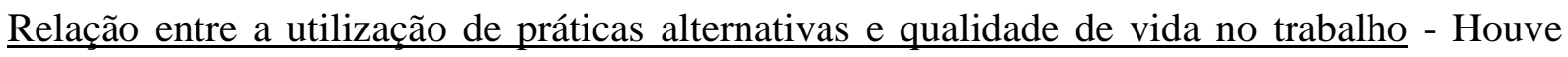
incremento no nível de consciência profissional dos funcionários do quadro funcional da empresa; melhor e mais sensata avaliação de seu auto-conhecimento; fortalecimento do potencial produtivo; segurança e estabilidade emocional na execução de suas atividades laborais.

\subsubsection{Empresa 4}

\begin{tabular}{|l|l|}
\hline \multicolumn{2}{|c|}{ Identificação } \\
\hline Ramo & Banco de investimentos \\
\hline Porte & Grande \\
\hline Número de empregados & 1.500 \\
\hline Faixa etária do entrevistado & 40 a 50 anos \\
\hline Tempo de atuação na empresa & Menos de um ano \\
\hline Formação escolar & Pós-graduação \\
\hline Pessoa entrevistada & Gerente de seleção \\
\hline
\end{tabular}

Breve histórico da empresa - A empresa pesquisada existe há 40 anos. Durante cerca de 30 anos funcionou como grupo financeiro, até ser desmembrado, nos anos 90. O acionista principal desejava concentrar suas atividades apenas em banco de investimentos e, por essa razão, vendeu a parte relativa ao banco aberto. A empresa cresceu na direção de investimentos, leasing, previdência e, atualmente, faz parte de um grupo que atua também em outros segmentos. 
Momentos de crise - Embora não fosse empregada da empresa no momento da venda do banco, a entrevistada avalia que aquele foi um momento de forte crise para os empregados, tanto para aqueles que já atuavam no segmento que não foi vendido, quanto para os que eram do banco e foram reaproveitados no novo momento. Os relatos de empregados que estavam na empresa na época, segundo a entrevistada, denotam insegurança, angústia e preocupação.

Momento em que começou a utilizar a prática alternativa - Embora não tenha certeza sobre a data de início, refere a entrevistada que o proprietário, ao participar de uma reunião com outros banqueiros, ouviu um relato sobre uma contratação que deixou de ser efetuada, em função dos resultados de um exame grafológico. Ele se interessou pelo assunto e trouxe o exame para o grupo, por meio de uma empresa terceirizada.

$\underline{\text { Práticas alternativas utilizadas na organização }}$

\begin{tabular}{|l|l|l|}
\hline \multicolumn{1}{|c|}{ Prática } & \multicolumn{1}{c|}{ Freqüência } & \multicolumn{1}{c|}{ Área } \\
\hline Grafologia & Rotineiramente & $\begin{array}{l}\text { Recrutamento e seleção } \\
\text { Processos de promoção }\end{array}$ \\
\hline
\end{tabular}

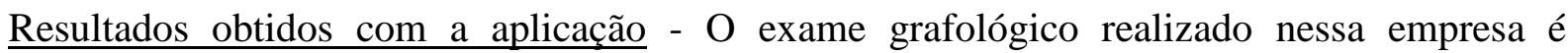
eliminatório. Se contra-indicar um candidato, ele não será admitido, salvo com autorização do presidente e, por esta razão, faz parte da cultura local. Em termos de resultados, as pessoas estão mais próximas do perfil desejado, das características da área e focadas na parte financeira, que é o negócio da organização.

Vantagens - O Conselho Regional de Psicologia (CRP) proibiu o emprego de ferramentas projetivas como o Wartegg, o qual, na opinião da entrevistada, que é psicóloga, era um bom teste e se comparava à grafologia. Com a proibição, a grafologia tornou-se a única ferramenta projetiva disponível, embora não tenha sido preparada por psicólogos. A avaliação dessa prática é muito complexa. A entrevistada fez um curso sobre o assunto e avalia que a análise é demorada, o que inviabiliza a realização pela própria empresa.

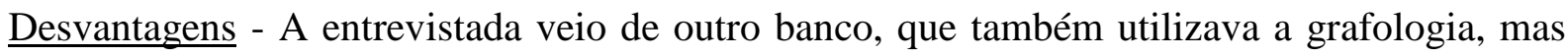
como mais uma ferramenta de seleção. Considera que, se tivesse outra ferramenta projetiva, 
poderia mostrar que problemas identificados na análise grafológica são, às vezes, situacionais e não componentes do perfil do candidato.

Como aplica essa prática - Informa ao candidato ao processo seletivo que ele será submetido a um exame grafológico e de raciocínio lógico. O candidato assina uma declaração de consentimento, concordando que os resultados sejam entregues ao gerente da área.

Em seguida, recebe uma folha sulfite, em que deverá escrever uma redação, com tema e tempo livres. É informado, todavia, que os candidatos costumam concluir a redação entre 20 e 25 minutos. É permitido e fazer rascunho mas não pode utilizar o verso da folha. Deve assinar, ao final.

Se aprovado, seu currículo e o resultado dos testes serão passados para a área solicitante. O gerente é quem faz a entrevista e, em função dos custos, tem direito a pedir até dois laudos grafológicos completos. A partir daí, escolhe o candidato com quem vai trabalhar.

Aceitação do corpo gerencial - Calcula que há $80 \%$ de aceitação. Os $20 \%$ de discordância referem-se aos casos em que se indica uma pessoa e o resultado é negativo ou quando o gerente indica alguém para promoção e seu candidato não é aprovado.

$\underline{\text { Relação entre a visão de mundo e de sociedade e dos valores propostos nesta organização e a }}$ aceitação/utilização de práticas alternativas - Há relação, pois a grafologia faz parte do padrão definido pelo fundador da empresa.

Aceitação/discordância por parte dos empregados - Calcula em torno de $60 \%$ a aceitação. Isso ocorre porque os empregados estão sujeitos a serem submetidos ao teste, além de indicarem parentes e amigos para a seleção e nem sempre são aprovados, o que gera algum desconforto. O índice de aprovação dos que se submetem ao exame grafológico é de apenas $15 \%$.

Relação entre a utilização de práticas alternativas e a motivação dos empregados - Não existe relação alguma. As pessoas vêem a prática como um teste e, como tal, é motivo de preocupação. A entrevistada considera que o exame traz angústia por que é eliminatório. 
Relação entre a utilização de práticas alternativas e a qualidade de vida no trabalho - Não há relação.

\subsubsection{Empresa 5}

\begin{tabular}{|l|l|}
\hline \multicolumn{2}{|c|}{ Identificação } \\
\hline Ramo & Marketing Interno \\
\hline Porte & Pequeno \\
\hline Número de empregados & 17 \\
\hline Faixa etária do entrevistado & 40 a 50 anos \\
\hline Tempo de atuação na empresa & Mais de um e menos de cinco anos \\
\hline Formação escolar & Pós-graduação \\
\hline Pessoa entrevistada & Sócio \\
\hline
\end{tabular}

Breve histórico da Empresa - Trata-se de uma empresa formada por dois sócios: $M$ e $I$. Ambos atuavam como gerentes: $M$ na área industrial, em uma multinacional, e, $I$, em uma agência de publicidade. A empresa propôs a $M$ uma parceria para abrir uma empresa em São Paulo. Este propôs a sociedade a $I$ e os dois aceitaram o desafio. A parceria com a empresa, contudo, não se concretizou e os dois resolveram abrir sozinhos a agência de publicidade, o que aconteceu há dois anos e meio.

A empresa é especializada em endomarketing, gestão de pessoas e demais práticas voltadas para o público interno, e conta com 17 empregados; 14 em São Paulo e três em Porto Alegre.

$M$ tem se dedicado às questões ligadas à gestão de pessoas e $I$ à Publicidade e Propaganda. $M$ relata que, quando era gerente industrial, chegou a ter 400 subordinados e, por isso, acredita que aprendeu a se relacionar com as pessoas, além de gostar mais dessa área do que da gestão de negócios.

Momentos de crise - Trata-se de uma empresa jovem, que está tentando se consolidar no mercado e, por isso, tem enfrentado as crises normais dessa característica, não apenas em termos financeiros, mas também nos aspectos relacionados às definições de gestão.

Momento em que começou a utilizar a prática alternativa - Em agosto de 2004, os sócios começaram a discutir a definição de papéis e o relacionamento entre si. A proposta era de 
construir uma identidade própria para a empresa e, em conjunto, desenvolver um Planejamento Estratégico para os três anos seguintes. Ante essa dificuldade, $M$ pediu ajuda a uma especialista em astrologia, com quem se relacionava no convívio pessoal. Na visão de $M$, era possível contratar um economista que lhe acenaria com dez cenários distintos e ele teria que escolher um. Segundo ele próprio, sua indagação foi puramente heterodoxa: uma vez que poderia obter dez cenários com um economista, porque não contratar um astrólogo para também apoiá-lo na definição desse cenário?

A partir dessa premissa, contratou a profissional, cujo trabalho foi iniciado no mês de outubro de 2004. Até o momento da entrevista, no mês de janeiro de 2005, haviam sido concluídas algumas etapas, outras já estavam previstas para acontecer no decorrer de 2005, dentre elas, a contratação de mais um profissional; desta feita, com apoio da análise astrológica. $M$ refere não ter uma visão esotérica do assunto e sim pragmática.

Práticas alternativas utilizadas na organização

\begin{tabular}{|l|l|l|}
\hline \multicolumn{1}{|c|}{ Prática } & \multicolumn{1}{c|}{ Freqüência } & \multicolumn{1}{c|}{ Área } \\
\hline Astrologia & Rotineiramente & $\begin{array}{l}\text { Recrutamento e seleção } \\
\text { Gestão }\end{array}$ \\
\hline Tarô & Rotineiramente & Aconselhamento \\
\hline Numerologia & Utilizou apenas uma vez & Definição da razão social \\
\hline
\end{tabular}

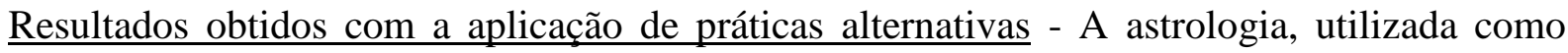
uma forma de autoconhecimento e interação grupal, a partir da análise de sinastria que foi feita entre os sócios da empresa, contribuiu para que o planejamento de metas fosse realizado com mais brevidade, bem como a decisão de convidar uma pessoa, membro da equipe de colaboradores, a compor o grupo de sócios. A ferramenta tem funcionado como apoio à tomada de decisão. Além disso, utilizaram o discurso astrológico em práticas comerciais; cita o exemplo de uma peça que fez para uma indústria farmacêutica, no qual utilizou os quatro elementos da natureza e suas respectivas cores.

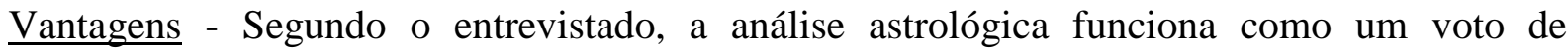
desempate pois, quando os sócios chegam a um impasse, o apoio da ferramenta alternativa contribui com uma visão técnica para a tomada de decisão. 


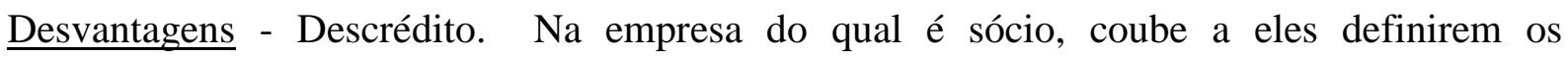
instrumentos de gestão a serem utilizados e por isso foram aceitos, embora, inicialmente, fossem encarados por alguns como uma "piada". O entrevistado acredita que, em uma corporação de grande porte, a implementação de ferramentas alternativas enfrentaria dificuldades, em função da visão distorcida, esotérica, e pouco pragmática de alguns de seus gestores.

Como aplica essa prática - A astrologia foi utilizada na definição de papéis entre os sócios, fazendo com que eles mudassem até mesmo de atividade e está sendo empregada na seleção de um profissional sênior. A empresa está adotando-a como um processo padrão. Prepara-se, este ano, para atuar na gestão de carreira.

Deseja ainda que cada empregado faça seu mapa individual para que, depois, possam agir no conjunto, mas não sabe ainda como a especialista atuará nessa questão, pois se trata de um trabalho piloto. No caso dos sócios, o trabalho iniciou-se com a análise do seu mapa astrológico, seguido da de seu sócio. Segundo o entrevistado, esse saiu da consulta completamente surpreso com a riqueza de detalhes. Posteriormente, uma terceira pessoa que trabalhava para eles e que, doravante, atuará como sócia, fez seu mapa, permanecendo em consulta com a especialista durante cinco horas. Após o processo individual, eles se reuniram para conversar sobre seus mapas. Como resultado, ocorreram mudanças individuais e na própria empresa. O problema atual que ele identifica é o alto custo do projeto, se considerado o fato de ser uma empresa de pequeno porte.

Aceitação do corpo gerencial - Os sócios, na totalidade, aceitaram a prática..

$\underline{\text { Relação entre a visão de mundo e de sociedade e dos valores propostos nessa organização e a }}$ aceitação/utilização de práticas alternativas - Para o entrevistado, a visão mais esotérica de tais ferramentas poderia assustar as pessoas. Como o grupo gerencial de sua empresa tem uma visão pragmática, encara-a como mais uma ferramenta de apoio à gestão de pessoas. Justifica sua resposta alegando que é engenheiro e para ele "dois mais dois resulta em quatro". Porém, os dois sócios estão passando pela crise dos 40 anos e, para eles, a questão abre-lhes a visão para outras práticas. Além disso, considera a visão de desespero: estavam num beco 
sem saída, procurando caminhos alternativos. Considera que falta, aos profissionais que atuam com ferramentas alternativas, uma visão de marketing, uma agregação de valor com um posicionamento mais executivo.

Aceitação/discordância por parte dos empregados - A aceitação foi muito boa, no primeiro momento. Para o conjunto de empregados, ele está desenhando um projeto que possibilite a cada um conhecer seu próprio mapa astrológico e, a partir do autoconhecimento daí derivado, tornar esse um conhecimento da equipe, de forma que beneficie a todos.

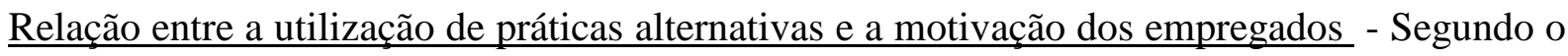
entrevistado, é difícil avaliar. As mulheres consideram o projeto interessante, enquanto os homens o classificam como uma piada, embora eles não tenham feito o próprio mapa. Entre os três sócios, melhorou a motivação.

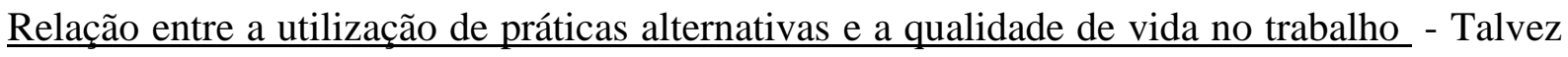
exista, sim, indiretamente. O fato é que, a partir da astrologia, cada um dos sócios começou a demonstrar mudanças individuais. Ele, por exemplo, considera ter uma estreita relação e até exagerada, com seu filho, embora antes passasse muito tempo longe dele. Desde que leu seu mapa, passou a levá-lo ou a buscá-lo na escola, por exemplo. Quanto à qualidade de vida no trabalho, especificamente, não sabe dizer. Relata ter criado uma sala de descompressão para o grupo. Contudo, não conseguiu ainda utilizá-la para o objetivo para o qual foi criada, ou seja, descomprimir, embora as pessoas utilizem o espaço.

Observações - Em sua avaliação, está crescendo a utilização da astrologia. Mas, em relação à numerologia, não aconteceu o mesmo. As propostas de mudança no nome da empresa não foram bem aceitas, pois o novo nome não passou pelo crivo do marketing. A única mudança foi no logotipo, cuja estrela tinha 20 pontas e agora terá 21 pontas. Conclui que a numerologia não causou maiores impactos.

Com relação ao evento em que utilizou intensamente as cores e seus elementos (fogo, terra, ar e água), considera que a iniciativa foi integralmente aceita pela empresa. Analisa que 
ferramentas alternativas, como a cromoterapia, já são amplamente utilizadas pelas organizações, as quais, no entanto, não a abordam com a conotação de ferramenta alternativa.

Pensa que falta visão de marketing aos especialistas. Para ele, ainda, as pessoas físicas nas organizações utilizam as ferramentas alternativas. Citou o caso de duas empresas de grande porte, em que uma gerente faz o mapa astrológico de seus empregados, mas não é prática utilizada institucionalmente. Talvez o problema seja o esoterismo implícito em detrimento do que é pragmático. Sua visão pragmática, faz com que veja-as como ferramentas que o apóiam na tomada de decisão. Por exemplo, utiliza o tarô para auxiliá-lo nesse processo.

\subsubsection{Empresa 6}

\begin{tabular}{|l|l|}
\hline \multicolumn{2}{|c|}{ Identificação } \\
\hline Ramo & Escritório de advocacia \\
\hline Porte & Pequeno \\
\hline Número de empregados & 50 \\
\hline Faixa etária do entrevistado & Mais de 50 anos \\
\hline Tempo de atuação na empresa & Mais de um e menos de cinco anos \\
\hline Formação escolar & Nível superior completo \\
\hline Pessoa entrevistada & Gerente de pessoal \\
\hline
\end{tabular}

Breve histórico - A empresa foi fundada há 30 anos por um advogado, que dá nome ao escritório. Há cerca de 20 anos, o fundador transferiu a direção do escritório para o filho e quatro amigos, que estavam se formando em direito na Universidade de São Paulo e se afastou, tendo retornado apenas recentemente, por causa dos problemas que estão ocorrendo.

Atualmente, tem em torno de 50 empregados, incluindo os estagiários, que são recrutados e tratados com a mesma rigidez aplicada aos empregados fixos. Segundo o entrevistado, a organização tem dificuldades, como todas as demais. O centro de sua atenção, contudo, dirige-se para a comunicação entre os sócios. Aliás, foi a partir de uma crise que se estabeleceu no ano de 2000, que a astrologia começou a ser utilizada. Nesse período, o entrevistado foi admitido, com o objetivo de profissionalizar a empresa. Os sócios, por sua vez, afastaram-se da direção, passando apenas a desfrutar dos lucros auferidos pela organização. 
Como resultado, a empresa começou a ter problemas de lucratividade até que, recentemente, o fundador se reaproximou da administração, em face do baixo faturamento. O maior problema dos sócios, na avaliação do entrevistado, é a falta de comunicação.

\section{$\underline{\text { Momentos de crise }}$}

1. Quando o fundador passou a administração para o filho e os sócios.

2. Em 2000, quando ocorreu uma crise de relacionamento entre os sócios. Na época, foi contratado o astrólogo como consultor e o entrevistado como gerente, de forma a profissionalizar a organização.

3. No momento, o fundador reaproximou-se pois a empresa está com dificuldades financeiras.

Momento em que começou a utilizar a prática alternativa - Em 2000, época em que a crise de relacionamento se acirrou. A ferramenta foi apresentada aos sócios, a partir da proposta inicial da esposa de um deles, que fez seu mapa astrológico. Os cinco proprietários, por curiosidade, resolveram fazer também seus mapas e o mapa astrológico da organização. Um astrólogo, especializado em astrologia empresarial, foi contratado para desenvolver esse trabalho.

Práticas alternativas utilizadas na organização

\begin{tabular}{|c|l|l|}
\hline \multicolumn{1}{|c|}{ Prática } & \multicolumn{1}{|c|}{ Freqüência } & \multicolumn{1}{c|}{ Área } \\
\hline Astrologia & Rotineiramente & Recrutamento e seleção \\
\hline
\end{tabular}

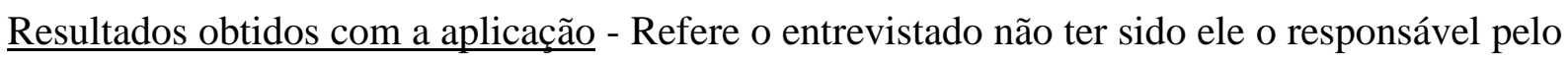
trabalho desenvolvido e ter críticas ao produto recebido. Para este, a proposta do especialista é que a astrologia possibilita que cada sócio, conhecendo seu parceiro através do mapa astrológico, tenha mais facilidade para entendê-lo e lidar com ele. Durante algum tempo, como resultado do trabalho, verificou-se maior sinergia entre os sócios. Considera que o que ocorreu, na verdade, foi uma forma de terapia individual e não a resolução dos problemas existentes. Tanto assim que essa sinergia não durou muito tempo e, em função dos problemas 
de comunicação entre eles, novas crises têm ocorrido. O entrevistado critica a astrologia, da forma como é conhecida hoje, pois é muito vinculada ao campo do místico, esotérico e do horóscopo. Não tem credibilidade científica.

No que concerne aos resultados, ele utiliza a astrologia ocidental e a oriental sempre que nova contratação é realizada e a astrologia é aplicada como uma ferramenta complementar, para confirmar ou não os dados obtidos na seleção, o que ocorre em $80 \%$ dos casos.

Vantagens - Trata-se de uma ferramenta complementar às tradicionais. Ele só a utiliza para confirmar os dados obtidos no processo de seleção. Quando não obtém confirmação dos dados, fica atento para verificar possíveis problemas. Mas não contra-indica candidato a partir dos dados da análise astrológica, bem como não utiliza apenas uma ferramenta para a tomada de decisão. Considera que trata a seleção de forma holística.

\section{Desvantagens:}

1. A astrologia, da forma como hoje é conhecida, tem um estigma que lhe tira a credibilidade. Por essa razão, acredita que a ferramenta deve mudar de nome. Refere também que o mapa astrológico não é o horóscopo diário apresentado nos jornais.

2. Como se trata de um mapa astrológico, é preciso de tempo para preparar uma análise minuciosa.

3. Outro problema é que a astrologia necessita da hora precisa do nascimento. No entanto, esse dado é também questionável, ou seja, qual hora considerar: a do nascimento ou a da concepção? No caso da empresa, há a mesma indagação: a hora em que se registrou a empresa na Junta Comercial ou a hora em que o fundador pensou em criar a empresa?

\section{Como aplica essa prática:}

- $\quad$ Recrutamento 
1. Escolhe candidatos diretamente da Universidade de São Paulo, da Pontifícia Universidade Católica e do Mackenzie.

2. Analisa o curriculum vitae.

3. Faz entrevista surpresa por telefone.

- Seleção

1. Solicita preenchimento de ficha pré-entrevista por extenso: dados simples, apresentação pessoal; leituras e hábitos; estudo e interesses; relacionamentos; redação sobre o tema: quem sou eu?

2. Aplica teste sobre conhecimento de inglês.

3. Na entrevista, enfatiza valores - família, comunicação verbal e corporal.

- Decisão

a. Disponibilidade

b. Comunicação no processo;

c. Não-indicação (a empresa não contrata pessoas indicadas);

d. Consulta à astrologia oriental e ocidental;

e. Perfil;

f. Orientação paterna;

g. Organização pessoal.

Aceitação do corpo gerencial - Os sócios querem resultados. Não se envolvem na forma como o entrevistado faz a seleção.

Relação entre a visão de mundo e de sociedade e dos valores propostos nessa organização e a aceitação/utilização de práticas alternativas - Há relação. Considera-se ateu. É filho de mãe japonesa e pai holandês. Refere diferenças na forma como essas duas culturas tomam 
decisões: os orientais demoram mais do que os europeus. Critica a astrologia ocidental que, para ele, é ligada ao catolicismo e mais mística. Tanto assim, que refere livro lançado que liga o Código da Vinci à Santa Ceia, da qual participaram 12 apóstolos, o mesmo número de signos da astrologia. Diz confiar na astrologia chinesa, que é prática. Usa mais a astrologia chinesa do que a ocidental.

Aceitação/discordância por parte dos empregados - Os empregados não sabem que a empresa utiliza a astrologia. Conhecem apenas o que é sistematizado, porque tem credibilidade.

Relação entre a utilização de práticas alternativas e a motivação dos empregados - Não há relação. O que faz é utilizar como ferramenta complementar na escolha dos candidatos. Quando este já pertence ao quadro de empregados, não faz uso da ferramenta pelos motivos já expostos, ou seja, não tem credibilidade e comprovação científica.

Relação entre a utilização de práticas alternativas e a qualidade de vida no trabalho - Não percebe qualquer relação.

\section{Observações}

1. A astrologia é complementar: não muda sua decisão em razão dela.

2. Questiona qual a data de nascimento da empresa a ser considerada, tanto quanto a data de nascimento das pessoas. Quanto mais se aprofunda no assunto, mais tem dúvidas.

3. Tem noções de grafologia, mas não utiliza a ferramenta em seleção. 


\subsubsection{Empresa 7}

\begin{tabular}{|l|l|}
\hline \multicolumn{2}{|c|}{ Identificação } \\
\hline Ramo & Comércio varejista \\
\hline Porte & Pequeno \\
\hline Número de empregados & 12 \\
\hline Faixa etária do entrevistado & 40 a 50 anos \\
\hline Tempo de atuação na empresa & Mais de cinco anos \\
\hline Formação escolar & Nível superior completo \\
\hline Pessoa entrevistada & Sócia-proprietária \\
\hline
\end{tabular}

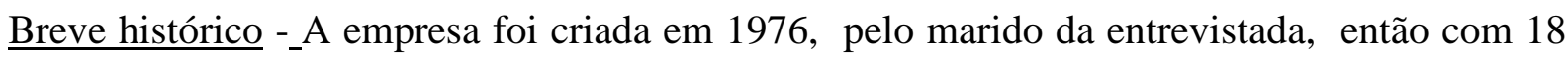
anos de idade, na cidade do Rio de Janeiro. Ele e um amigo gostavam de bicicleta e desejavam trabalhar. Resolveram então unir o prazer à vontade de trabalhar e abriram uma loja no bairro de Botafogo. A sociedade com o amigo, durou pouco mais de dois e se dissolveu. O marido permaneceu com o negócio.

Nos anos 80, a loja começou a vender ciclomotor e, depois, motos. No final daquela década, entrou definitivamente para o mercado de bicicletas e aí se firmou.

Nos anos 90, com a entrada no mercado da montain bike e a construção de ciclovias na cidade, a empresa cresceu. Além disso, segundo a entrevistada, o marido já privilegiava a figura do cliente, naquela época em que o comprador ainda tinha pouca importância.

Nesse sentido, começou a promover passeios de ciclistas e, com a onda da montain bike, a empresa apareceu em diversas reportagens de revistas. Os passeios promovidos por eles aconteciam nas noites de terça-feira e chegavam a reunir três mil ciclistas. A empresa foi precursora dos passeios ciclísticos que se seguiram posteriormente.

Em 1994, com a entrada de bicicletas importadas, o faturamento do negócio estagnou e, em determinado momento, declinou, dado o número de pessoas que entraram nesse mercado. Foi preciso promover um ajuste nas contas da empresa.

No final dos anos 90, a situação reverteu-se. A empresa, após uma campanha desenvolvida pela fabricante de bicicletas, para que as lojas se especializassem em seus produtos, tornou-se 
parceira daquela indústria, e uma de suas maiores revendedoras no Brasil e a segunda no Rio de Janeiro. A organização é semelhante a uma concessionária de carros e, por causa do excelente desempenho, tem recebido prêmios nos últimos cinco anos da fabricante que representa. Em 2002, foi eleita por esta como a melhor loja do Brasil e, por isso, seus donos receberam como prêmio uma viagem para assistir à corrida da modalidade na França.

Quanto à entrevistada, trabalhava em uma multinacional, na área de $\mathrm{RH}$, quando namorava o marido, fundador da empresa. Depois, deixou sua atividade e vem atuando, desde 1991, na administração da empresa: ela cuida da parte de RH e ele da área comercial.

A empresa possui duas lojas no Rio de Janeiro, uma em Laranjeiras, com oito empregados, e uma filial no Méier, com quatro empregados. Seu objetivo agora é tornar o negócio, que é um comércio varejista, em uma empresa profissional, além de crescer e ampliar o número de lojas.

Momentos de crise - Na época do Plano Real, a empresa entrou em crise financeira.

Momento em que começou a utilizar a prática alternativa - Quando ocorreu a crise financeira, com a queda no faturamento da empresa, a entrevistada, que sempre gostou de esoterismo, tanto que havia feito o seu mapa astrológico, do marido e dos filhos, com uma astróloga no Rio de Janeiro, resolveu solicitar um mapa também da empresa, a outra especialista.

O mapa mostrou que a empresa crescera muito, mas apontava para a necessidade de uma reestruturação. A partir dessa análise, procedeu-se a cortes e redução no tamanho da empresa, para garantir a sua continuidade. A astrologia foi utilizada como apoio, nessa fase. O trabalho astrológico consistiu na elaboração do mapa dos donos, principalmente do fundador, da empresa e da sinastria entre eles.

Depois dessa experiência, passaram a fazer o mapa anualmente, pois a astróloga orienta-os como uma pessoa de fora da organização. O mapa da empresa mostrou que sua principal característica é a dispersão. Por essa razão, optou-se por nova reestruturação, mas com foco. Tanto assim que ocorreram vários reposicionamentos, como, por exemplo, na área de 
informática. A astrologia contribui também em aspectos como recrutar, selecionar e aprimorar.

O desejo dos sócios é crescer, ter uma qualidade de vida melhor. Também aí a astrologia auxilia, por exemplo, no recrutamento de um profissional, verificando se o momento do candidato é o que a empresa precisa, bem como ajuda a verificar se é chegado o momento da saída do empregado, uma vez que ele poderia causar problemas no futuro. Era preciso muita transparência e a astrologia tem ajudado, inclusive no recrutamento para os cargos-chave.

\section{Práticas alternativas utilizadas na organização}

\begin{tabular}{|c|c|c|}
\hline Prática & Freqüiência & Área \\
\hline Astrologia & Rotineiramente & $\begin{array}{llll}\text { Recrutamento e seleção } & \text { e } \\
\text { aconselhamento } & & & \end{array}$ \\
\hline Grafologia & $\begin{array}{lll}\text { Utilizou algumas vezes por } \\
\text { tempo determinado }\end{array}$ & Recrutamento e seleção \\
\hline Numerologia & Utilizou apenas uma vez & Gestão \\
\hline
\end{tabular}

Resultados_obtidos com a aplicação de ferramentas alternativas - Acredita que a escolha do dia e da hora para a abertura da loja do Méier, conferiu-lhe uma assertividade maior e tornoua melhor do que a de Laranjeiras, que é a matriz. Por essa razão, optará novamente pela orientação da astrologia, se abrir uma nova loja.

Em recrutamento e seleção, ajuda a verificar se o candidato tem o que a empresa precisa dele.

Em relação à numerologia, a análise coincidiu com a astrológica, indicando como característica um alto grau de dispersão, importante para a compreensão da empresa, por ambos, uma vez que marido é mais dispersivo do que a entrevistada.

Nesse aspecto, a astrologia contribui, ao indicar uma direção. Ajudou a introduzir essa visão na empresa, a visualizá-la como uma pequena empresa/familiar, que deve se profissionalizar, não ser paternalista e ser informatizada, mas que depende de terceiros e da clientela. 
Acredita ainda que a astrologia ajudou, ao orientar a empresa a ir devagar, em face das variáveis externas, e aos sócios a participarem de cursos para tornar a empresa mais profissional.

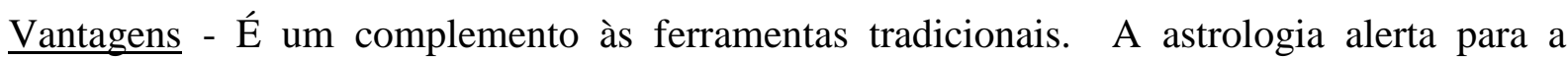
necessidade de formação dos seus sócios. Além disso, considera que se montasse uma empresa/sociedade sem a orientação de data e horário adequados, a empresa teria menos sucesso. Acredita que existem questionamentos que precisam ser feitos e não o são. Cita, por exemplo, a indagação sobre porque uns enriquecem e outros não. Nesse caso, não é apenas a formação que conta. Existe algo a mais, uma assertividade maior.

Desvantagens - Não acerta 100\%. Analisa algumas previsões como genéricas, razão pela qual avalia cada previsão antes de tomar qualquer decisão.

Como aplica essa prática - Tem um contrato informal com a astróloga. É uma relação de confiança que se estabeleceu com a consultora, tanto que já tentou outra profissional mas não deu tão certo. Trata-se de uma relação semelhante à de um médico e seu paciente.

Faz a previsão astrológica uma vez por ano. Quando, durante o ano, tem alguma dificuldade ou precisa tomar alguma decisão, como, por exemplo na área financeira, busca diversos recursos para apoiá-la na tomada de decisão, como ocorre com qualquer consultor.

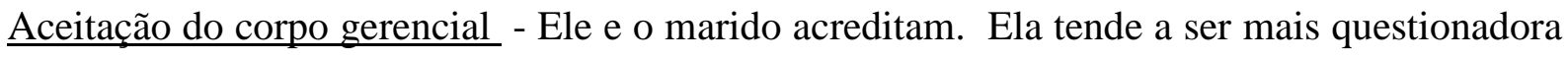
do que ele, pois se considera mais racional e mais voltada para as questões práticas do que o marido.

Relação entre a visão de mundo e de sociedade e dos valores propostos nessa organização e a aceitação/utilização de práticas alternativas - Há relação. A entrevistada considera-se mais espiritualizada; acredita que existe sempre algo a mais, que ainda não foi explicado. Pergunta-se o porquê das coisas e fatos, como o seu próprio nascimento, casamento, o nascimento de seus filhos. A análise astrológica ajudou muito na compreensão e na educação 
deles. Os recursos da astrologia são dificilmente encontrados em outras ferramentas. O astrólogo, como todo consultor, estando distante, vê aspectos que ela não percebe.

Aceitação/discordância por parte dos empregados - Os empregados não sabem que ela faz o mapa astrológico. Alguns são um pouco preconceituosos. A informação, portanto, não é divulgada, salvo quando há proximidade e sintonia entre os donos e o empregado.

Relação entre a utilização de práticas alternativas e a motivação dos empregados - Não há relação direta. No entanto, a astrologia detecta quando um determinado profissional está enfrentando problemas.

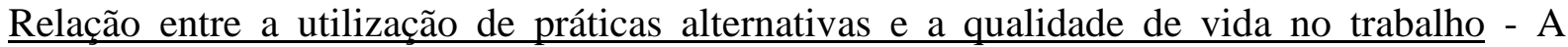
astrologia é muito clara, mas não aponta nem é árbitro. No caso do mapa da empresa, há indicação de que é necessário trabalhar muito para alcançar os resultados esperados. Sabe, então, que terá que trabalhar mais do que outras pessoas, as quais, parece-lhe, conseguem as coisas com maior facilidade. Mas os astros mostram também que o resultado só vem com o tempo. Então, ajuda a clarificar e possibilita a ela e ao marido terem uma boa qualidade de vida, na medida em que aspectos importantes, como levar os filhos para a escola, almoçarem todos juntos, etc. são considerados.

Observações - Astrologia: usada no recrutamento e seleção de cargos-chave e promoção de empregados. Uma área-chave para a empresa é a de vendas, pois o contratado leva cerca de seis meses para estar adaptado. Além disso, o mercado é precário (mais candidatos com pouca qualidade). A astrologia permite analisar características comportamentais (caráter da pessoa).

Foi utilizada também como orientação para inaugurar a filial da empresa, localizada no bairro do Méier, na melhor data e horário sugeridos. 


\subsubsection{Empresa 8}

\begin{tabular}{|l|l|}
\hline \multicolumn{2}{|c|}{ Identificação } \\
\hline Ramo & Varejo - gasolina \\
\hline Porte & Médio \\
\hline Número de empregados & 300 \\
\hline Faixa etária do entrevistado & 40 a 50 anos \\
\hline Tempo de atuação na empresa & Mais de cinco anos \\
\hline Formação escolar & Nível médio concluído \\
\hline Pessoa entrevistada & Proprietário \\
\hline
\end{tabular}

Breve histórico da empresa - Trata-se de uma rede de postos de gasolina, situada na cidade de São Paulo. A empresa foi fundada em 1947 pelo avô do entrevistado. Este era vendedor da Standard Oil e, por esta razão, acabou por abrir um posto com a bandeira Esso. A empresa prosperou e tornou-se, nos anos 70, a maior revendedora de gasolina da América Latina.

Em 1978, a Petrobras ofereceu quatro postos na Rodovia dos Bandeirantes e a empresa mudou sua bandeira. Nesse período, chegou a ter 1.600 empregados.

Alguns anos depois, ocorreram desavenças com os sócios externos e, depois,com a morte do avô, fundador da empresa, as disputas pela herança da família fizeram com que a empresa entrasse em crise e tivesse reduzido o seu tamanho. Hoje está com cerca de 300 empregados.

Momentos de crise - Em 1978, quando a empresa recebeu quatro postos e mudou de bandeira e, posteriormente, por questões relacionadas à herança do avô.

Momento em que começou a utilizar a prática alternativa - O entrevistado sempre gostou de feng shui e práticas alternativas. Contudo, cita uma vivência em particular que o levou a solicitar um estudo a um especialista. Relata um sonho que teve, cujo ponto central foi o logotipo da empresa de seu tio, que enfrentava forte crise, pouco depois de tê-lo mudado.

O entrevistado sugeriu ao tio que encomendasse um estudo de feng shui. A orientação do especialista foi que a empresa retornasse ao logotipo antigo. Como resultado, em dois meses, o faturamento dobrou. 
Práticas alternativas utilizadas na organização

\begin{tabular}{|l|l|l|}
\hline \multicolumn{1}{|c|}{ Prática } & \multicolumn{1}{c|}{ Freqüência } & \multicolumn{1}{c|}{ Área } \\
\hline Feng shui & Rotineiramente & Qualidade de vida no trabalho \\
\hline Radiestesia & Rotineiramente & Gestão \\
\hline Espiritualismo & Rotineiramente & Gestão \\
\hline
\end{tabular}

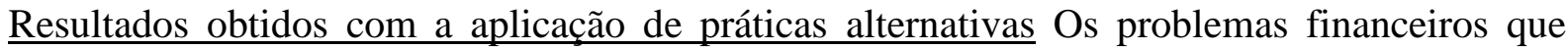
vinha enfrentando diminuíram. Após ter implantado o feng shui, a radiestesia e ter adotado o espiritualismo, separou a sociedade e resolveu as pendências.

Além disso, refere que seu negócio não piorou, o que, para o entrevistado, já é muito positivo. Hoje informa saber quando é preciso demitir, pois a pessoa está destoando da equipe; antes, não conseguia fazer essa distinção.

Depois de aplicar o feng shui passou a perceber harmonia, inclusive com os empregados e pessoas externas. A energia mudou.

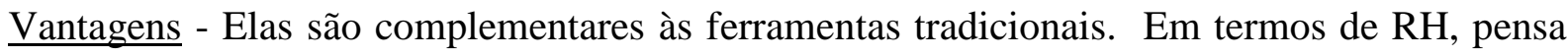
que uma pessoa que esteja mal-humorada tende a administrar mal. Mas, para adotar ferramentas alternativas é preciso acreditar nelas.

Desvantagens - É muito caro, principalmente porque, para ele, as pessoas que procuram esse tratamento, estão em crise financeira.

Como aplica essa prática - Em radiestesia, tem acompanhamento mensal desde 2003. Quanto ao feng shui, fez as modificações em 1999 e, agora, consulta sempre que necessário. Relata ainda freqüentar sessões espiritualistas rotineiramente.

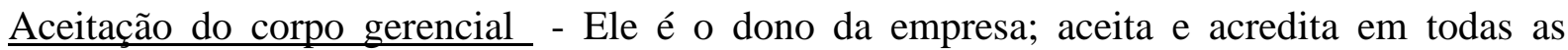
ferramentas que utiliza. O pai, que também é dono, não vai às sessões de espiritualismo, mas acredita. 
$\underline{\text { Relação entre a visão de mundo e de sociedade e dos valores propostos nessa organização e a }}$ aceitação/utilização de práticas alternativas - Para o entrevistado, há relação, pois é preciso acreditar nas práticas para poder aceitá-las.

Aceitação/discordância por parte dos empregados - Todos os empregados sabem e aceitam as práticas.

Relação entre a utilização de práticas alternativas e a motivação dos empregados - Segundo o entrevistado, a motivação melhorou muito. Antes, tão logo chegava o final do expediente, os empregados iam embora. Hoje, muitos deles permanecem após o horário, por vezes até às 20 horas.

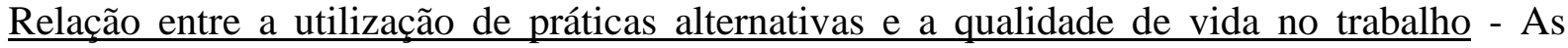
pessoas sentem-se bem com o ambiente harmonioso ali existente. Trabalham melhor.

\subsubsection{Empresa 9}

\begin{tabular}{|l|l|}
\hline \multicolumn{2}{|c|}{ Identificação } \\
\hline Ramo & Marketing direto \\
\hline Porte & Médio \\
\hline Número de empregados & 250 \\
\hline Faixa etária do entrevistado & 40 a 50 anos \\
\hline Tempo de atuação na empresa & Mais de cinco anos \\
\hline Formação escolar & Pós-graduação \\
\hline Pessoa entrevistada & Proprietário \\
\hline
\end{tabular}

Breve histórico - Empresa de marketing direto, que utiliza como instrumentos a tevê, catálogo e Internet, fazendo distribuição em todo o Brasil.

Conforme consta no site, a empresa integra as Organizações Globo e atua no mercado há oito anos. Inicialmente, vendia seus produtos apenas por meio de tevê e catálogo, o que possibilitou o acúmulo de um know-how único em vendas virtuais, mesmo antes da criação do comércio pela Internet. 
A vocação e a cultura desenvolvidas naquele tipo de venda, desde o início de suas operações, facilitou a entrada e a aceitação da empresa na Internet, cujo lançamento ocorreu em 1997. Desde então, o site da organização tornou-se um forte canal de vendas, com mais de 40.000 itens comercializados.

Atualmente, a empresa opera em todo o território nacional, atendendo e entregando produtos vendidos em vários municípios.

Momentos de crise - A crise que também se tornou uma grande oportunidade foi por ocasião da expansão da empresa, que nascera como um canal de tevê, para o catálogo e a Internet.

Momento em que começou a utilizar a prática alternativa - Quando se sentiu a necessidade de harmonizar as relações entre os profissionais que atuavam na organização.

Práticas alternativas utilizadas na organização

\begin{tabular}{|l|l|l|}
\hline \multicolumn{1}{|c|}{ Prática } & \multicolumn{1}{c|}{ Freqüiência } & \multicolumn{1}{c|}{ Área } \\
\hline Feng shui & Rotineiramente & Saúde ocupacional \\
\hline Radiestesia & Utilizou apenas uma vez & Saúde ocupacional \\
\hline
\end{tabular}

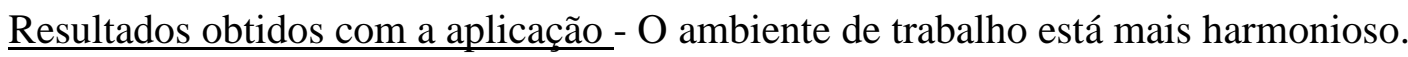

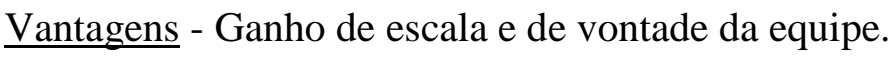

Desvantagens - Não sabe comparar.

Como aplica essa prática - Posicionamento das áreas e redefinição das cores em cada uma delas.

Aceitação do corpo gerencial - Muito boa.

$\underline{\text { Relação entre a visão de mundo e de sociedade e dos valores propostos nesta organização e a }}$ aceitação/utilização de práticas alternativas - Segundo o entrevistado, a intenção é lembrar que "passamos mais tempo na empresa do que em nossas casas". 
Aceitação/discordância por parte dos empregados - Nenhuma resistência.

Relação entre a utilização de práticas alternativas e a motivação dos empregados - Há relação: o empenho e o moral melhoraram.

Relação entre a utilização de práticas alternativas e a qualidade de vida no trabalho - Há relação: melhorou e harmonizou-se.

\subsubsection{Empresa 10}

\begin{tabular}{|l|l|}
\hline \multicolumn{2}{|c|}{ Identificação } \\
\hline Ramo & Varejo - revenda de pneus \\
\hline Porte & Médio \\
\hline Número de empregados & 280 \\
\hline Faixa etária do entrevistado & 40 a 50 anos \\
\hline Tempo de atuação na empresa & Mais de 5 anos \\
\hline Formação escolar & Pós-graduação \\
\hline Pessoa entrevistada & Sócia-proprietária \\
\hline
\end{tabular}

Breve histórico - A empresa surgiu há seis anos, a partir da cisão de uma sociedade que perdurou por 30 anos, e cujo nome era forte no mercado de revenda de pneus. A separação aconteceu, pois duas fornecedoras de pneus, multinacionais do setor, que a empresa atendia, não mais aceitaram que a revendedora atendesse a ambas.

Com a cisão, ela e os dois irmãos assumiram a revenda de apenas uma das fornecedoras. Segundo a entrevistada, no início, os três irmãos optaram pela carreira "solo", com apenas o nome da empresa e três pontos-de-venda, e um total de dez empregados. Eles utilizaram o prédio que é de uma cunhada e lá construíram a sede da empresa, que funciona até o momento.

Nestes seis anos, a organização cresceu: hoje tem quatro empresas, 20 pontos de vendas e um total de 280 empregados. Os irmãos continuam juntos: um é o presidente, o segundo é vicepresidente e a entrevistada atua como diretora de RH. 
Momentos de crise - A maior crise da empresa ocorreu no momento da cisão, quando os sócios se separaram e foi criada a empresa com a configuração atual. A oportunidade serviu para que os irmãos criassem a empresa com sua cultura e valores.

Momento em que começou a utilizar a prática alternativa - Segundo a entrevistada, ela e os irmãos sempre foram espiritualizados. Quando pequenos, costumavam receber a visita de um monge para fazer preces em sua casa. Essa vivência muito facilitou a aceitação de ferramentas alternativas na gestão organizacional.

Tanto assim que, no momento da cisão da empresa, uma de suas cunhadas viu em uma revista uma reportagem sobre feng shui. O assunto, há seis anos, era uma novidade e chamou a atenção da família. Resolveram então buscar apoio e aplicar o feng shui em suas casas e na empresa. O prédio que serviu como sede da empresa foi totalmente remodelado, conforme a concepção do feng shui.

Mas a influência não foi apenas nesse aspecto. A razão social da empresa foi escolhida com base na análise de numerologia e de radiestesia.

Há aproximadamente três anos, a especialista em feng shui sugeriu que eles passassem a utilizar também a radiestesia na rotina e sugeriu outro profissional pois avaliava que tinha limitações no conhecimento dessa área. Na época, os sócios foram em busca da profissional em radiestesia, que atua na empresa até o momento. Como os irmãos acreditavam nas energias, avaliaram que poderiam também utilizá-las para selecionar pessoas.

\section{Práticas alternativas utilizadas na organização}

\begin{tabular}{|l|l|l|}
\hline \multicolumn{1}{|c|}{ Prática } & \multicolumn{1}{c|}{ Freqüîncia } & \multicolumn{1}{c|}{ Área } \\
\hline Astrologia & Rotineiramente & $\begin{array}{l}\text { Recrutamento e seleção } \\
\text { Gestão }\end{array}$ \\
\hline Numerologia & Sempre que necessário & Gestão \\
\hline Radiestesia & Rotineiramente & $\begin{array}{l}\text { Recrutamento e seleção } \\
\text { Gestão }\end{array}$ \\
\hline Feng shui & Sempre que necessário & Qualidade de vida no trabalho \\
\hline
\end{tabular}




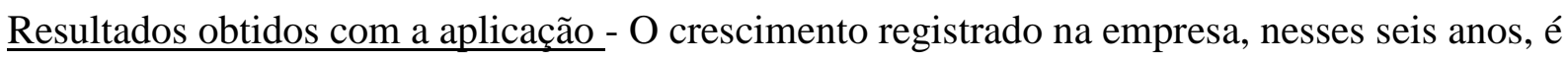
um dos resultados obtidos. A empresa recebeu prêmios como uma das revendedoras de pneus com melhores resultados para a fabricante.

Ressalta a entrevistada que não basta ter o apoio de ferramentas alternativas se não se trabalhar seriamente. Faz um paralelo com uma pizza que tem vários pedaços. As ferramentas se constituem em um dos fatores que contribuíram para esse crescimento, mas a competência e o esforço de todos têm sido fundamentais para os bons resultados auferidos. As práticas alternativas são um acessório que dá velocidade ao negócio

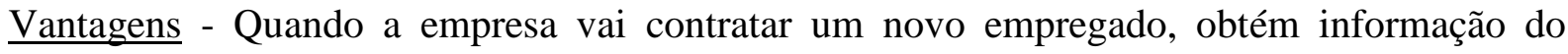
candidato através da análise do curriculum vitae, dos testes e da entrevista a que é submetido, mas nada se sabe dele em termos de vibrações. As ferramentas alternativas possibilitam que se escolha o candidato com mais energia, velocidade e vibração para a empresa.

No caso da astrologia, contribui também para tratar determinado assunto na hora certa e numa condição mais favorável

Desvantagens - Nem sempre consegue manter nas filiais da empresa a organização do espaço, condição básica para o feng shui.

Em relação à seleção de novos empregados, nem todo gestor gosta dos resultados. Por exemplo, ainda que o candidato seja aprovado em todas as etapas da seleção, se não for indicado na análise de radiestesia, não será contratado (essa é uma diretriz para toda a organização).

\section{Como aplica essa prática}

- Recrutamento e seleção: Na seleção dos empregados, todos passam pelas várias etapas de uma seleção com ferramentas tradicionais. Dois ou três dos melhores candidatos têm suas fichas enviadas para a radiestesista. A empresa, juntamente com a especialista da área, enumerou 27 perguntas que são respondidas na ficha do candidato, pela radiestesista. Como 
resultado, a ficha recebe uma pontuação que lhe confere o nível de bronze, prata ou ouro. O candidato bronze não será admitido. Entre uma avaliação prata e ouro, eles optam, na maioria das vezes, pela avaliação ouro, salvo nos casos em que o candidato avaliado como prata têm as características fortes em aspectos considerados relevantes para aquele cargo na organização. Já se tentou admitir alguns candidatos considerados bronze, mas, segundo a entrevistada, na maioria das vezes a admissão não foi feliz. A radiestesia mostra uma situação momentânea do candidato e pode, por isso, apontar aquele que terá melhor desempenho na organização no ato de sua admissão.

A radiestesia é utilizada na seleção de todos os empregados da empresa. A astrologia é utilizada no recrutamento e seleção de gerentes e diretores, pois mostra a essência do candidato. Quando há diferença no parecer da astróloga e da radiestesista, a entrevistada verifica com ambas o que está acontecendo. Em geral, as diferenças são explicáveis, pois as duas ferramentas se complementam.

- Gestão: A astróloga e a radiestesista são contatos constantes da empresa. Os especialistas em numerologia e feng shui são chamados quando necessário, como, por exemplo, para a escolha, definição e organização dos espaços de um ponto-de-venda.

A astrologia e a cosmologia (estudo das cores) são utilizadas diariamente na gestão empresarial. A astróloga fez o mapa da empresa, com base na sua data de inauguração; o mapa de cada sócio da empresa; e realizou a sinastria entre os mapas de todos. Além desse trabalho, a especialista envia semanalmente uma análise astrológica e cosmológica, na qual mostra datas e horários, adequados e inadequados, para determinadas tomadas de decisão. $\mathrm{O}$ mapa astrológico é afixado no mural da empresa (Anexo 5) e fica disponível para consulta de todos os empregados.

Também foi elaborada uma agenda anual, baseada na astrologia e na cosmologia, que foi distribuída para todos os empregados e fornecedores.

Embora enfatize que não atue de forma regrada apenas pelas definições de astrologia, esta serve de parâmetro para a escolha de horas e também para as atividades do dia/hora. A 
entrevistada e seus irmãos tem por hábito utilizar ou realizar atividades que estejam favoráveis astrologicamente naquele momento.

A reunião semanal da diretoria começa com a leitura do clima astrológico. Esse procedimento é feito para que os diretores possam cuidar de aspectos considerados impróprios para aquela data. A astróloga fornece também um mapa bimestral, que é discutido pela diretoria como pauta de reunião.

A razão social da empresa foi concebida com base na numerologia e radiestesia.

Quando deseja abrir um novo posto de revenda, a primeira análise é feita pela radiestesia que estuda a planta do local. Em seguida, o feng shui faz a análise de como organizar o espaço (a entrevistada diz ter um kit de feng shui). Se tudo está conforme, passa-se para a astrologia, que orienta se a filial está no momento para ser aberta e qual a melhor data para sua inauguração.

A numerologia é utilizada como apoio para verificar se o nome e o número da rua são favoráveis (dependendo do número do imóvel, o ponto-de-venda não é alugado); além de auxiliar na definição de determinados aspectos, como o número do banco, a placa do veículo e o número de telefone.

A empresa adota ainda o hábito de receber periodicamente a "bênção de feng shui".

Aceitação do corpo gerencial - Todos os gerentes aceitam a prática, até porque se trata de diretriz da alta direção. Em alguns casos, a aceitação aconteceu porque eles constataram que a análise feita pelos especialistas estava correta.

$\underline{\text { Relação entre a visão de mundo e de sociedade e dos valores propostos nessa organização e a }}$ aceitação/utilização de práticas alternativas - Há relação. A própria criação dos fundadores da empresa aconteceu a partir da adoção de valores espiritualistas. A entrevistada considera, ainda, que a aceitação acontece ou em função da criação/educação da pessoa ou porque, em 
algum momento, a pessoa fica em dificuldade financeira ou de outro tipo e busca a ajuda das ferramentas alternativas.

Aceitação/discordância por parte dos empregados - Para a entrevistada, existem empregados que aceitam e até trazem planta de suas casas para a análise de radiestesia. A especialista já fez palestras sobre feng shui para aqueles que acreditam. Mas existem também empregados que não acreditam.

Relação entre a utilização de práticas alternativas e a motivação dos empregados - Há relação. Cita como exemplo episódios em que se tem consciência de que o funcionário deu o melhor de si mas o resultado não foi satisfatório. Nesses dias, constata na análise astrológica que a ocasião não estava favorável para aquela ação. É uma forma de motivá-lo a continuar. Além disso, as "dicas" são bem-vindas e o motivam.

Relação entre a utilização de práticas alternativas e a qualidade de vida no trabalho - Há relação. A entrevistada complementa dizendo que "é melhor estar sentada no escritório ouvindo o barulho d'água de uma fonte colocada por orientação do feng shui, do que ouvir o barulho de um martelo".

A percepção de que houve aplicação do feng shui e da radiestesia no espaço é sutil. Para a entrevistada, uma pessoa mais sensível, quando visita a empresa, percebe a boa energia do local. O mesmo ocorre com fornecedores que chegam, percebem e fazem comentários sobre como aquele lugar é muito "legal".

Os funcionários acendem incenso normalmente na empresa. Fazem a bênção do feng shui fora do expediente, mas, se necessário, há tratamentos também dentro do horário normal de trabalho.

Finaliza dizendo que, de toda forma, "é preciso assumir e acreditar para dar certo!". 
Observações - Quando se visita uma empresa, é possível identificar que foram utilizados recursos de feng shui. Nesse caso, uma fonte, plantas de vários tipos, um cristal no alto de uma porta são indicativos da possível utilização de ferramentas alternativas.

A empresa possui vários ambientes, nos quais é possível verificar que foram planejados com base no feng shui: na sala da diretora, estão expostos quadros e adereços, nas cores escolhidas de acordo com o local que simbolizam. Em uma das salas, situada na parte dos amigos, existem fotos de amigos e fornecedores que são importantes para a organização. $\mathrm{Na}$ área do dinheiro, encontra-se a sala do diretor financeiro.

A entrevistada ressalta a importância do especialista ter foco em negócios, tanto que mudou de astrólogo e radiestesista pois os anteriores não tinham vivência empresarial: "uma coisa é um trabalho no nível pessoal, outra coisa é conhecer de negócio". Segundo ela, é difícil encontrar no mercado profissionais com esse perfil.

\subsubsection{Empresa 11}

\begin{tabular}{|l|l|}
\hline \multicolumn{2}{|c|}{ Identificação } \\
\hline Ramo & Petróleo \\
\hline Porte & Grande \\
\hline Número de empregados & 50.000 \\
\hline Faixa etária do entrevistado & 40 a 49 anos \\
\hline Tempo de atuação na empresa & Mais de um e menos de cinco anos \\
\hline Formação escolar & Pós-graduação \\
\hline Pessoa entrevistada & Coordenador do programa \\
\hline
\end{tabular}

Breve histórico - Trata-se de empresa estatal de energia, que atua nas áreas de prospecção, produção, refino e distribuição de petróleo, além dos segmentos de petroquímica e geração de energia. É a maior empresa do Brasil e a segunda maior empresa da América do Sul e, até o ano de 1995, era responsável pelo monopólio estatal de petróleo. Com as mudanças na Constituição, a empresa se reestruturou e passou a competir no mercado nacional e internacional. 
No final da década de 90 e início do século atual, a empresa enfrentou problemas relacionados a acidentes, envolvendo segurança e meio ambiente, o que motivou a criação de . uma gerência executiva voltada para as questões de Segurança, Meio Ambiente e Saúde.

Com o atual governo, a empresa reviu suas ações de estar voltada apenas para os aspectos de mercado, focando suas ações também para a contribuição ao crescimento do País, através do incremento de patrocínios, melhoria no relacionamento com os sindicatos e amplo programa de comunicação institucional, o que propiciou que fosse considerada a terceira marca mais lembrada pelos brasileiros.

Momentos de crise - A empresa enfrentou vários momentos: os dois últimos mais significativos foram em 1995, quando deixou de ter o monopólio sobre a prospecção, exploração, produção e refino de petróleo no Brasil, e, em 2000, quando enfrentou problemas de segurança no trabalho e problemas ambientais.

Momento em que começou a utilizar a prática alternativa - Há cerca de dez anos, foi implantada uma experiência piloto no Edifício Sede da empresa, com prática de ioga, por iniciativa da área de saúde ocupacional. A ioga vem sendo reconhecida como um instrumento eficaz de combate ao estresse e de relaxamento, e foi escolhida para servir exatamente a esse propósito, ou seja, disponibilizar uma ferramenta opcional para empregados que tivessem interesse em investir em sua qualidade de vida.

Até 1998, havia um grupo de pessoas que participava de aulas regulares. No final de 1999, com a ampliação do escopo do programa: não apenas serviços de ioga, como também de tai chi chuan e shiatsu passaram a ser oferecidos, nos dois prédios da empresa, situados na cidade do Rio de Janeiro, em espaços provisórios..

As práticas de ioga e tai chi chuan ganharam um espaço físico definitivo, com a inauguração das atividades do Centro de Promoção de Saúde da empresa em 2004. Nessa época uma empresa terceirizada passou a fornecer esses serviços mediante contrato.. Três novas turmas de ioga foram formadas para atender à demanda crescente de interessados. 
A partir de 2005, o programa foi retomado também na sede da cidade de Salvador, com o mesmo foco de combate ao estresse.

\section{Práticas alternativas utilizadas na organização}

\begin{tabular}{|l|l|l|}
\hline \multicolumn{1}{|c|}{ Prática } & \multicolumn{1}{c|}{ Freqüência } & \multicolumn{1}{c|}{ Área } \\
\hline Shiatsu & Rotineiramente & Saúde ocupacional/QVT \\
\hline Ioga & Rotineiramente & Saúde ocupacional/QVT \\
\hline Tai chi chuan & Rotineiramente & Saúde ocupacionalQVT \\
\hline
\end{tabular}

$\underline{\text { Resultados obtidos com a aplicação - A empresa está, ainda, em processo de medição }}$ quantitativa. Qualitativamente, refere receber constantes feedbacks sobre a importância do Programa de Gerenciamento do Estresse (que inclui ioga, tai chi chuan e shiatsu) para alívio não apenas do estresse, mas também de problemas provenientes da coluna vertebral, como hérnias de disco, artroses, etc.

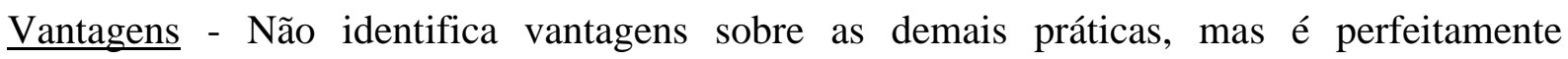
identificável seu benefício como complemento aos demais instrumentos de linha mais tradicional, como tratamento medicamentoso, fisioterapia e lazer geral.

Desvantagens - Não observa desvantagem, exceto o fato de se acreditar que essas terapias, sozinhas, são panacéia para todos os problemas.

Como aplica essa prática - O Programa de Gerenciamento do Estresse (ioga, tai chi chuan e shiatsu) é disponibilizado no Rio de Janeiro e, recentemente, em Salvador. Atualmente, o programa do Edifício Sede dispõe de sete turmas de ioga (280 empregados) e duas turmas de tai chi chuan (50 empregados), bem como três turmas de ioga (160 participantes) e duas turmas de tai chi chuan (40 participantes) em outros dois locais. Quanto ao shiatsu, é realizado em sessões de 30 minutos, atendendo a cerca de 250 pessoas por mês. Em Salvador, o atendimento está restrito a cerca de 45 pessoas por mês, dada a dificuldade de espaço.

As turmas de ioga e tai chi chuan se reúnem duas vezes por semana cada, sendo que a permanência no programa está condicionada à assiduidade e às condições estabelecidas previamente no regulamento. Caso o participante desatenda ao regulamento, é excluído do 
programa. Uma fila de espera mantém as turmas constantemente repletas, com reposições imediatas.

A participação no programa é estendida, gratuitamente, a todos os empregados, contratados e estagiários.

Aceitação do corpo gerencial - O processo transcorre com tranqüilidade, na medida em que há regime de compensação das horas utilizadas nas práticas. Além disso, a maioria das turmas tem aulas fora do horário núcleo da empresa, o que facilita conciliar o horário de trabalho com o das práticas terapêuticas.

$\underline{\text { Relação entre a visão de mundo e de sociedade e dos valores propostos nessa organização e a }}$ aceitação/utilização de práticas alternativas - Há relação, pois, na medida em que a empresa valoriza a saúde, o bem-estar e o desenvolvimento do indivíduo, fica fácil agregar à prática o patrocínio a atividades dessa natureza. Há, porém, questões a serem trabalhadas, porque os programas alternativos ainda não têm o respaldo científico.

Aceitação/discordância por parte dos empregados - Não percebe discordância dos nãoparticipantes quanto às práticas alternativas. $\mathrm{O}$ discurso geral é da falta de tempo, pois o mundo de hoje exige uma série de papéis que obriga as pessoas a priorizarem suas atividades, em detrimento de outras que poderiam contribuir para sua qualidade de vida.

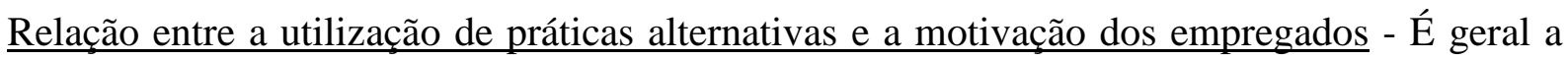
opinião dos participantes de que seu nível de motivação aumenta, a partir do momento em que se inserem nessas práticas, tanto para o trabalho quanto para a vida.

Relação entre a utilização de práticas alternativas e a qualidade de vida no trabalho - Há relação. O programa integra o Programa de Promoção de Saúde e Qualidade de Vida da área de Serviços Compartilhados da empresa. Seu objetivo está alinhado com a proposta de melhorar a qualidade de vida dos funcionários. 


\subsubsection{Análise dos dados obtidos nas empresas pesquisadas}

Este estudo teve por objetivo geral reunir informações que possibilitassem identificar e descrever a utilização, na gestão de pessoas das empresas pesquisadas, de ferramentas consideradas alternativas e quais os resultados alcançados.

Os dados encontrados no levantamento quantitativo mostraram que a maioria das práticas alternativas é pouco utilizada pelas organizações de grande porte. Para os especialistas em RH das organizações, as razões relacionam-se à ausência de demanda para novas práticas, uma vez que:

- É importante implantar práticas em gestão de pessoas que tenham validade científica.

- As ferramentas tradicionais suprem as necessidades das organizações para as quais prestam serviço.

A única ferramenta citada por representantes de empresas, de pequeno, médio e grande portes, em todos os levantamentos realizados, foi a grafologia. Esse dado corrobora os dados de Jung (op.cit.) porque se trata de uma prática comum em empresas de alguns países europeus e na própria América do Sul, como ocorre na Argentina, embora ainda não tenha sido totalmente aceita no Brasil.

O método quantitativo, utilizado na primeira etapa da pesquisa de campo, se empregado isoladamente, não teria sido capaz de identificar a utilização de outras ferramentas alternativas por organizações, conforme foi demonstrado, posteriormente, na pesquisa qualitativa.

A adoção de práticas alternativas pelas empresas sofreu a influência da direção superior. As ferramentas alternativas, na maior parte dos casos, foram determinadas pelo executivo principal e não por proposta da área de RH. Outro aspecto importante é que a implementação de ferramentas como a astrologia, a radiestesia e o feng shui está relacionado ainda à necessidade de superar processos de crise financeira ou de relacionamento. No caso da grafologia e do shiatsu não existe essa relação. 
Os dados coletados revelam, em síntese:

- A iniciativa pela adoção de práticas alternativas foi, em $81 \%$ dos casos, analisada por determinação do executivo principal da corporação. Apenas em 19\% dos casos a responsabilidade coube à área de $\mathrm{RH}$.

- $\quad$ As práticas são aplicadas nas empresas, da seguinte forma:

1. Astrologia:

- $\quad$ Em seleção de pessoal, o mapa do candidato é analisado como apoio à decisão sobre a contratação. O mapa astrológico indica as potencialidades do candidato e sua relação com a empresa que o contratará.

- $\quad \mathrm{Na}$ gestão empresarial, é utilizada através do mapa astrológico individual de cada sócio ou membro da equipe, da empresa e na sinastria, ou seja, comparação entre os mapas com o objetivo de identificar pontos de concordância e atrito entre as partes.

- $\quad$ Na elaboração do plano de trabalho, por meio de previsão astrológica periódica das pessoas e da organização. Neste caso, apóia a tomada de decisão, mostrando datas e horários nos quais temas da organização podem ser discutidos ou evitados. Em uma das empresas analisadas, a especialista faz a previsão astrológica utilizando também a cosmologia.

\section{Grafologia:}

Elaboração de laudo destinado a avaliar candidatos em recrutamento e seleção e processos de promoção. Na maior parte dos casos, o candidato recebe uma folha sulfite e uma caneta esferográfica para que redija um texto em letra cursiva, com tema livre, e aproximadamente 20 linhas assinando-a, ao final. A análise é feita a partir desse material.

3. Feng shui (cristais, essências florais e aromaterapia): 
Foram analisadas duas escolas. Em ambas, o especialista faz uma entrevista inicial com o cliente, buscando identificar os problemas que a organização apresenta naquele momento.

Em seguida o adepto da escola do chapéu negro solicita a planta baixa da organização. O adepto da escola da bússola, como o próprio nome indica, utiliza também a bússola para situar a planta da empresa. O próximo passo é analisar cada espaço, de acordo com o baguá e propor à empresa alterações no arranjo interno, como, por exemplo, mudança de uma área de trabalho de um local para outro do prédio, além da "cura" com objetos como cores, aromas, cristais, essências florais, objetos de madeira, metal, dentre outros.

\section{Radiestesia:}

- Em Recrutamento e Seleção - Uma empresa, após concluído o processo, encaminha ao radiestesista dois ou três candidatos, selecionados pelos métodos tradicionais. Foram identificadas indagações que a organização considera importantes que o empregado faça. A radiestesista utiliza o pêndulo para responder a essas perguntas e classifica o candidato em três categorias: ouro, prata e bronze. O candidato classificado como ouro será o escolhido.

- O radiestesista utiliza o pêndulo e a "vara mágica" para identificar energias negativas que podem trazer problemas para a empresa. O trabalho é feito tanto nas dependências da empresa quanto na planta baixa. Para os problemas identificados, o especialista sugere tratamentos energéticos (radiônicos). Foi utilizada em uma empresa, juntamente com a numerologia, para definir a sua razão social.

\section{Numerologia:}

Em gestão empresarial - A análise é feita com base na razão social, data de fundação e endereço (nome da rua e número) da organização. A partir desses dados, o especialista sugere alterações no nome, indica ou contra-indica a mudança para determinado endereço.

\section{Shiatsu, ioga, tai chi chuan:}


A organização analisada as utiliza em saúde ocupacional e qualidade de vida no trabalho, no programa de combate ao estresse

- Os resultados informados pelos gestores das organizações são os seguintes:

1. A grafologia auxilia na redução do turn over e na escolha do candidato com o melhor perfil (personalidade/caráter) para desempenhar a função pleiteada.

2. A astrologia apóia no processo de autoconhecimento e sinergia grupal, além de contribuir para a escolha do melhor candidato, nos processos de seleção e assertividade na definição de novos negócios. Seus resultados, todavia, são questionados por um dos entrevistados, que associa os resultados advindos do autoconhecimento a uma terapia individual que não resolve os problemas do grupo.

3. Os resultados do feng shui e radiestesia são relacionados à melhoria na harmonização do ambiente e, conseqüentemente, à qualidade de vida no trabalho.

4. Shiatsu, ioga e tai chi chuan: os dados qualitativos referem melhoria nos casos de estresse e dores na coluna vertebral.

5. Numerologia: mais conhecimento das características organizacionais; apóia a decisão para escolha de imóvel, e data adequada para inauguração.

6. As demais ferramentas (cristais, tarô, i-ching, florais, aromaterapia), não foram avaliadas do ponto de vista dos resultados alcançados pelos entrevistados.

7. Em termos globais, cabe citar os resultados obtidos pela empresa revendedora de pneus, que aponta crescimento muito positivo, a partir de sua reorganização e implementação nos processos de gestão de práticas alternativas.

- As vantagens e desvantagens, na opinião dos entrevistados, estão sintetizadas no Quadro 
Quadro 8 - Vantagens e desvantagens na utilização de práticas alternativas

\begin{tabular}{|c|c|}
\hline Vantagens & Desvantagens \\
\hline $\begin{array}{l}\text { Astrologia } \\
\text {. Contribui para a tomada de decisão. } \\
\text {. Complementa as ferramentas tradicionais. } \\
\text {. É assertivo na proposição de data e hora mais favoráveis } \\
\text { para tratar de novos negócios e assuntos. }\end{array}$ & $\begin{array}{l}\text { Astrologia } \\
\text { Descrédito em face da visão esotérica. } \\
\text { Precisa de dados que nem sempre estão disponíveis } \\
\text { (hora de nascimento, por exemplo). } \\
\text {. Imprecisa no dado que deve ser considerado (por } \\
\text { exemplo, concepção). } \\
\text {. Não acerta } 100 \% \text { das previsões. }\end{array}$ \\
\hline $\begin{array}{l}\text { Feng Shui } \\
\text { Complementa as práticas tradicionais. } \\
\text {. Harmoniza o ambiente. } \\
\text {. Gera ganho de escala e vontade da equipe. }\end{array}$ & $\begin{array}{l}\text { Feng shui } \\
\text {. É muito caro quando se está em crise financeira. } \\
\text {. É difícil manter o espaço organizado. }\end{array}$ \\
\hline $\begin{array}{l}\text { Grafologia } \\
\text {. Detecta aspectos da personalidade que outros não } \\
\text { identificam. } \\
\text {. Menos manipulável pelo candidato. } \\
\text {. Simplicidade e rapidez na aplicação. } \\
\text {. Única ferramenta projetiva. }\end{array}$ & $\begin{array}{l}\text { Grafologia } \\
\text { Não avalia aspectos como mentira. } \\
\text { O teste não é preciso e requer um bom grafólogo. } \\
\text { Gera desconfiança no candidato. } \\
\text { Os resultados podem ser situacionais e não } \\
\text { permanentes no perfil do candidato. }\end{array}$ \\
\hline $\begin{array}{l}\text { Radiestesia } \\
\text {. Analisa as vibrações energéticas do candidato e sua } \\
\text { relação com a empresa. }\end{array}$ & $\begin{array}{l}\text { Radiestesia } \\
\text { Os gerentes nem sempre aceitam quando a } \\
\text { radiestesista contra-indica um candidato. }\end{array}$ \\
\hline $\begin{array}{l}\text { Shiatsu/ioga/tai chi chuan } \\
\text {. Complementa as práticas tradicionais. }\end{array}$ & $\begin{array}{l}\text { Shiatsu/ioga/tai chi chuan } \\
\text {. Acreditar que essas terapias, sozinhas, resolvam } \\
\text { todos os problemas. }\end{array}$ \\
\hline
\end{tabular}

- Aceitação do corpo gerencial: como se tratou, na maior parte dos casos, de diretriz superior, não se observaram problemas com os gerentes, exceção feita nos casos de recrutamento e seleção, em que os candidatos por eles indicados e preferidos, foram contraindicados por uma dessas ferramentas.

- Relação entre práticas alternativas e visão de mundo: exceto no caso da grafologia, em que parte dos entrevistados considerou que não há relação; nos demais ela existe e é considerada por eles como forte.

- Aceitação/discordância por parte dos empregados: a utilização de algumas práticas não enfrenta resistência como o tai chi chuan, o shiatsu, a ioga. Nos demais, verifica-se boa aceitação do feng shui e da grafologia, e alguma resistência; ou a empresa não informa que utiliza, nos caos da astrologia e da radiestesia. 
- Relação entre motivação/QVT e práticas alternativas: os entrevistados, em sua maioria, não identificam relação desses temas com a grafologia e a astrologia. Nos demais casos (feng shui, radiestesia, ioga, tai chi chuan e shiatsu) a relação é forte.

\subsection{Análise dos dados à luz do referencial teórico}

Este estudo mostrou a existência de lacunas teóricas, a serem preenchidas, para a compreensão das práticas alternativas no âmbito da gestão das organizações. Cada uma das dimensões analisadas aborda um aspecto relevante para o estudo deste tema, embora, no âmbito global, não consigam dar conta do desafio proposto:

- A análise da dimensão psíquica, a partir da psicodinâmica organizacional, ao tratar do conteúdo ergonômico da tarefa, abre espaço para compreender as razões que podem levar uma empresa a introduzir ferramentas alternativas. O feng shui e a radiestesia, em sua proposta de harmonizar o ambiente, podem contribuir para torná-lo agradável àqueles que ocupam o espaço, independentemente do nível hierárquico. A grafologia e a astrologia, por sua vez, podem auxiliar na escolha da pessoa mais adequada para determinada atividade, de acordo com sua compatibilidade com o trabalho proposto, de forma a substituir o sofrimento no cumprimento de uma atividade que não dá prazer àquele indivíduo, pela realização profissional. A obra de Jung (1988), por sua vez, denota o quanto esse autor se aproximou das práticas alternativas. Ao citar a grafologia como plenamente reconhecida e realizar experimentos em astrologia, ainda que seus resultados não tenham sido benéficos para essa prática, o autor mostra-se receptivo à busca pelo alternativo.

- No que concerne à dimensão sociológica: o estudo mostrou que a aceitação de práticas alternativas rebate intensamente na cultura organizacional. A grafologia, por exemplo, embora vista com restrição por algumas categorias de profissionais que atuam em recursos humanos, é utilizada em empresas de porte do País: algumas delas multinacionais, tendo sido importadas de suas matrizes. 
Nas pequenas e médias empresas estudadas, tais ferramentas foram implementadas por iniciativa do próprio empresário. Neste sentido, há que se ressaltar a importância da figura do executivo principal, como patrocinador de práticas dessa natureza, contrariando a expectativa inicial, de que as inovações partissem da área de Gestão de Pessoas.

Neste sentido, a noção de diversidade cultural é um fato a ser considerado. Por um lado, os dados da pesquisa, encaminhada por carta, revelam a não disposição de profissionais da área de RH em experimentar práticas não corroboradas cientificamente; por outro, a predisposição de empresários em aceitar e implementar novas práticas. Empresas como o banco de investimentos e a comercializadora de pneus ilustram essa disposição. Nesse sentido, o conceito de cultura organizacional proposto por Schein (1992, p.12) é corroborado nos casos estudados. A importância que ele confere ao fundador é aqui fortalecida, uma vez que as duas empresas, depois de passarem por processos de cisão, foram reconstruídas por seus líderes, com base em novos patamares. As práticas alternativas aqui são por eles reforçadas, em relação aos demais membros, nas empresas que dirigem.

- A dimensão holística tem forte identidade com as práticas alternativas. Ações como shiatsu, tai chi chuan e ioga, na empresa de petróleo, e feng shui, na empresa de marketing direto, refletem a preocupação das organizações com o bem-estar de seus empregados.

A noção de espiritualidade observada em algumas empresas reforçam o conceito de Catanante (2002, p.523). Embora caminhem mais na direção interna à empresa, a preocupação em harmonizar ambientes, que beneficiem a todas as pessoas que a eles têm acesso, é uma demonstração da busca dessas organizações por ir além dos resultados organizacionais estritamente financeiros.

O estudo mostrou que as empresas, quando utilizam uma ou mais ferramentas alternativas, fazem uma composição delas com as práticas tradicionais. Testes psicológicos são complementados e não substituídos por avaliações como a grafologia e, em menor escala, a astrologia. A grafologia é tratada como alternativa por não ter status de teste psicológico aceito pelo Conselho Federal de Psicologia. Todavia, não é compreendida, pelas organizações pesquisadas, como uma ferramenta alternativa no sentido místico. 
Na mesma direção caminham o shiatsu, a ioga e o tai chi chuan, que são aceitos como ferramentas alternativas complementares às práticas tradicionais em saúde ocupacional e apóiam ações de qualidade de vida no trabalho.

- No tocante à dimensão administrativa, o ponto de convergência com as práticas alternativas é o apoio delas à seleção de pessoas que tenham maior capacidade de entrega para a empresa, por uma maior similaridade de idéias e ideais. Esse aspecto e a preocupação em tornar o ambiente mais harmônico e saudável para a organização estão em sintonia com a implementação do modelo de gestão de pessoas proposto por Dutra (2002).

Por fim, é importante ressaltar a análise de Fischer (2001) acerca das noções de conceito e moda. Não é intenção deste estudo propor uma nova moda na área de gestão de pessoas. Os dados aqui descritos são de cunho exploratório e, como tal, assim estão sendo interpretados. A validação ou não de quaisquer dessas práticas, portanto, deve ser objeto de estudo especifico. 


\section{CONCLUSÕES}

Este projeto de pesquisa tem como arquitetura conceitual responder a um desafio de pesquisa: penetrar em um campo pouco investigado em administração, na área de gestão de pessoas, que são as práticas alternativas em face da linha que divide o metafísico, entendido neste estudo como o "oculto", o "mágico", o "esotérico", do dado comprovado e, portanto, científico. Antes de analisar quaisquer dados, foi preciso encontrar um meio de identificar a existência de práticas desta natureza, daí o status de estudo exploratório a ele conferido. O estudo teve como intenção, também, construir uma tipologia que permitisse analisar a maior ou menor propensão das organizações para a aceitação e utilização de práticas alternativas.

O problema de pesquisa era como reconhecer a existência dessas práticas na gestão de pessoas e na cultura organizacional. Para analisá-lo, foram identificadas oito questõeschave.

Um desafio adicional foi encontrar autores que contribuíssem para a análise dos dados. Nesse sentido, cada uma das dimensões teóricas descritas foi importante para a análise dos dados, pois se mostraram complementares. Cabe destacar Jung (1977) nesse processo que, na sua busca por compreender a psique humana, não se esquivou de penetrar em áreas ocultas (ou esotéricas) e pesquisar práticas alternativas. A dimensão psicológica é complementada pela análise sociológica e, daqui, cabe destacar o aspecto da cultura organizacional e a contribuição de Edgar Schein (1992). Ao pontuar a enorme importância do fundador e do líder da organização, o autor abriu caminho para se entender as razões pelas quais algumas organizações apresentam cultura organizacional mais receptiva às ferramentas alternativas, como foi demonstrado nos estudos de casos.

A partir desta base de sustentação, foi possível ir a campo e entrevistar especialistas que atuam nas organizações e gestores de empresas que adotam algum tipo de prática 
alternativa. Dos resultados indicados no capítulo anterior, foi possível chegar a algumas conclusões, apresentadas a seguir.

A prática alternativa encontrada com maior freqüência foi a grafologia, seguindo-se da astrologia, do feng shui e da radiestesia. A numerologia, as essências florais, a aromaterapia, o shiatsu, a musicoterapia são menos freqüentes, embora outras ferramentas tenham sido ainda mais raramente mencionadas, como foi o caso do $i$-ching e do tarô, citados uma única vez. Entre as práticas alternativas, a adoção da radiestesia surpreendeu, por ser encontrada com certa freqüência, uma vez que, inicialmente, não estava relacionada entre as ferramentas a serem estudadas. Também se observou que a aplicação de cristais, da cosmologia e da cromoterapia estão associadas ao feng shui. Cabe observar ainda que as práticas alternativas são adotadas como complemento às práticas tradicionais; não foram observados casos de total substituição de uma pela outra. Portanto, tais práticas não são "alternativas" no sentido de que substituem as práticas tradicionais, mas sim no sentido que se colocam como uma opção a mais à disposição de administradores e profissionais de RH.

As motivações que levam à adoção das práticas alternativas podem ser reunidas em três grupos:

a) Gestão de negócios - a prática é adotada como ferramenta auxiliar no planejamento estratégico, sendo usada na definição de datas e horários para tomada de decisões (astrologia, $i$-ching, tarô e radiestesia) ou, ainda, para escolha da localização da empresa e da data de inauguração (numerologia).

b) Seleção de pessoal - práticas como a astrologia, a grafologia e a radiestesia são utilizadas para a seleção de pessoal, como uma estratégia para identificar o perfil adequado para a função na empresa, além de serem adotadas como "critério de desempate" entre candidatos com currículos profissionais equivalentes.

c) Qualidade de vida no trabalho - a aromaterapia, o feng shui, as essências florais, a musicoterapia, a aplicação de cristais e a radiestesia são práticas utilizadas para a 
harmonização do ambiente de trabalho, enquanto que o shiatsu, o tai chi chuan e a ioga são práticas relacionadas com a saúde ocupacional dos empregados.

Na maior parte dos casos estudados, a decisão por adotar práticas alternativas foi feita pela cúpula da empresa. O principal dirigente não só toma a iniciativa para a adoção das ferramentas, mas também é o incentivador de uma mudança na cultura organizacional da empresa que busca a aceitação das práticas alternativas como rotina. Verificou-se que gestores se decidem pela adoção dessas práticas em momentos de crise nos negócios, mas também simplesmente a partir da percepção de que é necessário harmonizar as equipes de trabalho. A fundação do negócio é outro momento que aparece como a motivação inicial para a adoção de práticas alternativas. De modo geral, a área especializada em RH na empresa limitou-se a implementar as práticas, após a decisão dos principais gestores da empresa. Observou-se que o uso da grafologia, em recrutamento e seleção, e o uso do shiatsu, tai chi chuan e da ioga em saúde ocupacional e qualidade de vida no trabalho, estão relacionadas com a presença de uma área específica de gestão de pessoas na empresa. Em comparação, práticas alternativas como o feng shui, a astrologia, e a radiestesia são observadas em empresas com estruturas mais horizontais, sem uma área de gestão especializada em RH. Em ambos os casos, porém, a decisão por adotar as práticas alternativas parte da cúpula da empresa e independe do consentimento ou iniciativa dos profissionais de RH. Além disso, alguns profissionais de RH manifestam resistência à adoção dessas práticas, argumentando que não há comprovação científica da eficácia das mesmas.

A grafologia mostrou-se a prática mais difundida, sendo encontrada em empresas de todos os portes. Devido ao pequeno número de empresas investigadas que adotam outros tipos de práticas alternativas, não foi possível verificar uma relação entre adoção e porte da empresa. De todo modo, a prática do shiatsu foi encontrada em duas empresas de grande porte, enquanto que as outras práticas observadas estavam presentes em empresas de pequeno e médio portes. Os valores e crenças do fundador da empresa ou matriz da organização mostraram-se como um fator mais determinante para a adoção de práticas alternativas do que o porte da empresa. 
No que se refere ao grupo de beneficiários, nota-se que as práticas voltadas diretamente para o desenvolvimento do negócio, como a astrologia, o $i$-ching, o tarô, a radiestesia e a grafologia, os principais beneficiários seriam os proprietários e acionistas das empresas. Um segundo grupo de beneficiários seriam os próprios profissionais de $\mathrm{RH}$, uma vez que as práticas alternativas podem configurar-se em ferramentas que facilitam a seleção e a gestão de pessoas, como nos casos da grafologia, da astrologia e da radiestesia. Finalmente, os empregados das empresas também seriam beneficiados pela adoção dessas práticas, uma vez que elas têm como objetivo a harmonização do ambiente de trabalho, contribuindo assim para uma melhor qualidade de vida. As práticas relacionadas com esses objetivos são a aromaterapia, o feng shui, as essências florais, o shiatsu, o tai chi chuan, a ioga, a musicoterapia, os cristais e a radiestesia.

Quanto aos resultados alcançados, os especialistas em práticas alternativas apontam para os benefícios subjetivos em funcionários e dirigentes (bem-estar emocional e físico, autoconhecimento, harmonia nas equipes de trabalho, etc.), além das vantagens estratégicas para o próprio negócio. Uma síntese das conclusões do estudo é apresentada no Quadro 9.

Quadro 9 - Síntese das conclusões do estudo exploratório sobre as práticas alternativas

\begin{tabular}{|l|l|}
\hline 1. Práticas mais freqüentes & $\begin{array}{l}\text { Grafologia. } \\
\text { Astrologia, feng shui, radiestesia, tai chi chuan, ioga, shiatsu. } \\
\text { I-ching, Tarô, numerologia (mais raramente). }\end{array}$ \\
\hline $\begin{array}{l}\text { 2. Áreas de gestão onde são } \\
\text { adotadas }\end{array}$ & $\begin{array}{l}\text { Gestão de negócios - planejamento estratégico (astrologia, i-ching, } \\
\text { tarô, radiestesia). } \\
\text { Seleção de pessoal - seleção de profissionais com perfil adequado; } \\
\text { critério de desempate (astrologia, grafologia, radiestesia). } \\
\text { Qualidade de vida no trabalho - programas de saúde ocupacional } \\
\text { (shiatsu, tai chi chuan, ioga, cristais, florais) e harmonização do } \\
\text { ambiente de trabalho (feng shui, aromaterapia, musicoterapia). }\end{array}$ \\
\hline $\begin{array}{l}\text { 3. Quem decide sobre a } \\
\text { adoção das práticas }\end{array}$ & $\begin{array}{l}\text { Cúpula dirigente da empresa; áreas especializadas na gestão de } \\
\text { pessoas nas empresas atuam na implementação das práticas, com } \\
\text { destaque para a grafologia e o shiatsu. }\end{array}$ \\
\hline $\begin{array}{l}\text { 4. Resultados da adoção das } \\
\text { práticas }\end{array}$ & $\begin{array}{l}\text { Especialistas em práticas alternativas que prestam serviços às } \\
\text { empresas destacam os aspectos relacionados ao bem-estar dos } \\
\text { empregados, assim como às vantagens para a gestão estratégica } \\
\text { das empresas. }\end{array}$ \\
\hline
\end{tabular}


Uma vez que o presente estudo teve caráter exploratório, não foi possível verificar a abrangência da adoção de práticas alternativas no universo das empresas de grande porte no Brasil. Em futuras investigações, poderão ser adotados outros métodos de coleta de dados, de modo a possibilitar uma amostra representativa. A tipologia apresentada neste estudo poderá servir como referência para essas futuras investigações. Os três tipos de posicionamento de empresas quanto à adoção de práticas alternativas, assim como as observações deste estudo, que fundamentam cada um desses tipos, são apresentados no Quadro 10.

\section{Quadro 10 - Tipologia de utilização das práticas alternativas}

\begin{tabular}{|c|c|c|c|}
\hline Tipologia & $\begin{array}{c}\text { Potencial de } \\
\text { utilização }\end{array}$ & Descrição da utilização & Descrição da empresa \\
\hline "A" & $\begin{array}{l}\text { Empresas } \\
\text { francamente } \\
\text { alternativas }\end{array}$ & $\begin{array}{l}\text { Utilizam ferramentas alternativas } \\
\text { em processos de gestão de pessoas } \\
\text { e mostram-se receptivas a utilizar } \\
\text { outras ferramentas. }\end{array}$ & $\begin{array}{l}\text { Empresa cujo sócio ou } \\
\text { proprietário é receptivo a } \\
\text { práticas alternativas, atua } \\
\text { e/ou interfere na gestão de } \\
\text { pessoas. }\end{array}$ \\
\hline "F" & $\begin{array}{c}\text { Empresas fracamente } \\
\text { alternativas }\end{array}$ & $\begin{array}{l}\text { Utilizam apenas um tipo de } \\
\text { ferramenta alternativa e mostram- } \\
\text { se pouco receptivas a novas } \\
\text { práticas. }\end{array}$ & $\begin{array}{l}\text { Empresa que utiliza } \\
\text { prática alternativa não } \\
\text { vinculada a aspectos } \\
\text { "místicos". }\end{array}$ \\
\hline "T" & $\begin{array}{l}\text { Empresas } \\
\text { francamente } \\
\text { tradicionais }\end{array}$ & $\begin{array}{l}\text { Não utilizam ferramentas } \\
\text { alternativas e mostram-se reativas } \\
\text { à possibilidade de vir a utilizá-las. }\end{array}$ & $\begin{array}{lrr}\text { Empresa } & \text { que vincula a } \\
\text { utilização } & \text { de práticas a } \\
\text { efetiva } & \text { comprovação } \\
\text { científica. } & \end{array}$ \\
\hline
\end{tabular}

No presente estudo, foi destacada a percepção dos especialistas, que prestam serviços às empresas que buscam adotar práticas alternativas. Assim sendo, outra possível linha de investigação futura poderá abordar a questão da percepção dos dirigentes quanto à adoção dessas práticas, assim como as percepções dos profissionais de RH quanto a essas práticas.

Um aspecto final: como se trata de uma área de pesquisa em gestão de pessoas, no qual algumas dessas práticas tendem a resvalar em aspectos de crenças, que ainda demandam por sistematização científica, recomenda-se cuidado especial no trato dessas questões. Sugere-se, pois, que cada ferramenta aqui analisada seja objeto de estudo individualizado, que acompanhe sua implantação e quantifique seus resultados nas 
empresas, o que lhes possibilitará serem passíveis de validação. De toda forma, o fato de se concluir pela existência de empresas que utilizam práticas alternativas, algumas das quais referem resultados positivos, é relevante e pode ser indicativo de que está nascendo, em gestão de pessoas, uma nova abordagem. 


\section{REFERÊNCIAS}

AMORIM, C.F.R.B. Um panorama do uso de práticas alternativas como técnica de diagnóstico ou intervenção e suas relações com a psicologia. São Paulo: Relatório de pesquisa, mimeo, 1995.

ANDERSON, Neil; SHACKLETON, Vivi. Recruitment and selection: a review of developments in the 1980s. Farnborough: Personnel Review, v.15, n.4,1986, p.19.

Q\&A: manager credits feng shui in financial recovery. New York: The American City \& County, sep. 2000, p. 66.

Management today. London: oct. 1994, p.17.

ARANHA, Maria L.de A., e, MARTINS, Maria H.P. Filosofando: introdução à filosofia. 2 $2^{\text {a }}$.ed. São Paulo: Ed.Moderna, 1993.

ARROYO, Stephen. Astrologia, psicologia e os quatro elementos: uma abordagem astrológica ao nível da energia e seu uso nas artes de aconselhar e orientar. São Paulo: Pensamento, 1975.

AKIYAMA, Kazusei. Práticas não-convencionais em medicina no município de São Paulo. São Paulo: 2004. Tese (Doutorado) - Faculdade de Medicina da USP.

BARTLETT, Sarah. Feng shui e o amor: como criar harmonia e energia em sua casa e em seu coração. Rio de Janeiro: Record/Nova Era, 2000.

BEN-SHAKHAR, Gershon at al. Can graphology predict occupational success? Two empirical studies and some methodological ruminations. Washington: Journal of Applied Psychology, v.71, n.4, nov.1986, p.645, 9 p.

BENENZON, Rolando. Teoria da musicoterapia: contribuição ao conhecimento do contexto não-verbal. São Paulo: Summus, 1988.

BERNIS, Maurício. Astrologia empresarial: adequando o tempo e o espaço à tomada de decisões. RAE light, v. 7, n. 1, São Paulo: FGV, jan./mar. 2000.

BOOG, Gustavo G.; BOOG, Magdalena T. Energize sua empresa! Como os florais podem dinamizar seu ambiente de negócios. São Paulo: Gente, 1997. 
O poder dos florais no trabalho. São Paulo: Makron, 1995.

. (Coord.). Manual de treinamento e desenvolvimento São Paulo: Makron Books, 1999.

BURINI, Elaine R.V. Astra inclinant, non determinant: símbolo, mito, arquétipo e religiosidade no signo de virgem - uma hermenêutica. São Paulo: 2002. Dissertação (Mestrado)- PUC-SP.

CAMAYSAR, Rosabis. Numerologia: suas leis, princípios e aplicações práticas na vida. São Paulo: Pensamento, 1993.

CAPRA, Fritjop. O ponto de mutação. São Paulo: Cultrix, 1986.

O tao da física: um paralelo entre a física moderna e o misticismo oriental. São Paulo: Cultrix, 1983.

CARVALHO, Antonio Vieira de. Seleção: princípios \& métodos. São Paulo: Pioneira, 2000.

CASADO, Tânia. Tipos psicológicos: uma proposta de instrumento para diagnóstico do potencial humano nas organizações. São Paulo: 1998. Tese (Doutorado)- FEA/USP.

CATANANTE, Bene. Gestão do ser integral: como integrar alma, coração e razão no trabalho e na vida. São Paulo: Infinito, 2000.

Espiritualidade no trabalho. In: BOOG, Gustavo e BOOG, Madalena (Coord.). Manual de gestão de pessoas e equipes. São Paulo: Gente, 2002.

CAUDRON, Shari. Your corporate horoscope. Cleveland: Industry Week, mar. 16, 1998, v. 247, n. 6, p. 64, 2 p.

CERDIN, Jean-L.; PERETTI, Jean-M. Trends and emerging values in human resource management in France. Londres: International Journal of Manpower, v.22, n.3, 2001, p. 216-225.

CERVO, Amado L.; BERVIAN, Pedro A. Metodologia científica. São Paulo: Prentice Hall, 2003.

CHAUI, Marilena. Convite à filosofia. 12.ed. São Paulo: Ática, 1999.

CHIAVENATO, Idalberto. Gestão de pessoas: o novo papel dos recursos humanos nas organizações. Rio de Janeiro: Elsevier, 1999. 
CISSAY, Monique. Numerologia: a importância do nome no seu destino. São Paulo: Pensamento, 1984.

CRAZE, Richard. Feng shui: a arte milenar chinesa da organização do espaço. Rio de Janeiro: Campus, 1998.

COLE, Joanne. Building heart and soul. New York: HR Focus, v. 75, n. 10, oct., 1998.

CREMA, Roberto. Introdução à visão holística: breve relato de viagem do velho ao novo paradigma. São Paulo: Summus, 1995.

Saúde e plenitude: um caminho para o ser. São Paulo: Summus, 1989.

DAVEL, Eduardo; VASCONCELLOS, João (Org.) Recursos humanos e subjetividade. Petrópolis: Vozes, 1996.

DAVIS, Keith; NEWSTROM, John W. Comportamento humano no trabalho. .São Paulo: Pioneira, 1992, v.1.

DAVIS, Louis E.; CHERNS, Albert B. The quality of working life. Problems, prospects, and state of the art, v.1, ,New York: The Free Press, 1975.

DEJOURS, Christophe. A loucura do trabalho: estudo de psicopatologia do trabalho. São Paulo: Cortez, 1988.

O fator humano. Rio de Janeiro: FGV, 1997.

A banalização da injustiça social. Rio de Janeiro: FGV, 1999.

A carga psíquica do trabalho. In:BETIOL, Maria Irene S. (coord.). Psicodinâmica do trabalho: contribuições da escola dejouriana à análise da relação prazer, sofrimento e trabalho. São Paulo: Atlas, 1994.

e ABDOUCHELI, Elisabeth. Desejo ou motivação? A interrogação psicanalítica sobre o trabalho. In:BETIOL, Maria Irene S. (coord.). Psicodinâmica do trabalho: contribuições da escola dejouriana à análise da relação prazer, sofrimento e trabalho. São Paulo: Atlas, 1994.

DOES your business have a soul? New York: HR Focus, v.75, n.10, oct.1998.

DURHAM, Eunice R. Cultura e ideologia. Rio de Janeiro: Ciências Sociais, v. 27, n.1, 1984, p.71 a 89. 
DUTRA, Joel S. Gestão de pessoas: modelo, processos, tendências e perspectivas. São Paulo: Atlas, 2002.

. (Org.) Gestão por competências: um modelo avançado para o gerenciamento de pessoas. São Paulo: Gente, 2001.

DY, Vitor L. Feng shui básico: manual completo da milenar ciência chinesa aplicado à vida moderna. São Paulo: Ground, 1997.

FACHIN, Odília. Fundamentos de metodologia. São Paulo: Saraiva, 2001.

FALCÃO, Paula Astrologia como ferramenta para Recursos Humanos. In: BOOG, Gustavo e BOOG, Madalena (Coord.). Manual de gestão de pessoas e equipes. São Paulo: Gente, 2002.

FERREIRA, Aurélio B.de H. Novo dicionário Aurélio da Língua Portuguesa. $3^{\text {a }}$.ed. Curitiba: Ed.Positiva, 2004.

FISCHER, André L. O conceito de modelo de gestão de pessoas - modismo e realidade em gestão de recursos humanos nas empresas brasileira. In DUTRA, Joel S. (Org.) Gestão por competências: um modelo avançado para o gerenciamento de pessoas. São Paulo: Gente, 2001.

FLEURY, Afonso; FLEURY, Maria T. L. Aprendizagem e inovação organizacional: as experiências de Japão, Coréia e Brasil. São Paulo: Atlas, 1995.

FLEURY, Maria T.L. Gerenciando a diversidade cultural: experiências de empresas brasileiras. RAE. São Paulo: FGV, 2000, v. 40, n. 3, g, p.18-25.

; e outros. Entre a antropologia e a psicanálise: dilemas metodológicos dos estudos sobre cultura organizacional. São Paulo: RAE, jan./mar., 1997, v. 32, n. 1, p. 23-37.

,; FISCHER, Rosa M. (Coord.) Cultura e poder nas organizações. São Paulo: Atlas, 1992.

GALVÃO, Lígia F. Práticas alternativas: uma leitura institucional da questão. São Paulo: Dissertação (Mestrado)- USP/Instituto de Psicologia, 2000, 2 v.

GIL, Antonio Carlos. Métodos e técnicas de pesquisa social. São Paulo: Atlas, 1999. 
Gestão de pessoas: enfoque nos papéis profissionais. São Paulo: Atlas, 2001.

GOLDENBERG, Mirian. A arte de pesquisar: como fazer pesquisa qualitativa em ciências sociais. $3^{\text {a }}$.ed. Rio de Janeiro: Record, 1999.

GOLDKORN, Roberto Bo. Feng shui: energia e prosperidade no trabalho. Rio de Janeiro: Campus, 1999.

GOODE, William J. Métodos em pesquisa social. São Paulo: Nacional, 1977.

GRAPHOLOGY in business. London: Management today. oct, 1994, p.17, 1p.

HALL, Calvin S.; LINDZEY, Gardner. Teorias da personalidade. São Paulo: EPU, 1990.

HAMAKER-ZONDAG, Karen. Astropsicologia: uma chave para o autoconhecimento e o crescimento pessoal. Rio de Janeiro: Nova Fronteira, 1988.

HARDIN, P. What's your sign? Companies use otherworldly assessment methods to choose the right employees. New York: Personnel J, 9, 1995, p. 66-67.

HENDRICKSON, Paula. Put feng shui to work in your office. New York: Office Solutions, aug, 2000, p.12.

HERATY, N.; MORLEY, M. In search of good fit: policy and practice in recruitment and selection in Ireland. Londres: Journal of Management Development, v. 17, n. 9, 1998, p. 662-685.

HOBSON, J.S.P. Feng shui: its impacts on the Asian hospitality industry. International. Lismore: Journal of Contemporary Hospitality Management, v. 6, n. 6, 1994, p. 21-26.

HORNSBY, Jeffrey S., et al. Emerging growth companies and the at-risk employee: the viability of pre-employment honesty testing. Cincinnati: Advanced Management Journal, v. 57, n. 4, 1992, p .4, 6 p.

JUNG, Carl G. XVIII sincronicidade: um princípio de conexões acausais Petrópolis: Vozes, 1988.

Aion: estudos sobre o simbolismo do si-mesmo. Petrópolis: Vozes, 1988. 
O eu e o inconsciente. Petrópolis: Vozes, 2003.

Memórias, sonhos, reflexões. Rio de Janeiro: Nova Fronteira, 1996.

KERLINGER, Fred N. Metodologia da pesquisa em ciências sociais: um tratamento conceitual. São Paulo: EPU, 1979.

KING, Stephen. Graphology: writing on the wall. Londres: Management Development Review, v. 7, n. 5, , 1994, p. 26-28.

KURAMOTI, Matiko N. e outros. Holística cabocla: uma experiência organizacional de empresa que deu certo. Petrópolis: Vozes, 1994.

LAKATOS, Eva M.; MARCONI, Marina A. Metodologia científica. 3..ed. São Paulo: Atlas, 2000.

LIMONGI-FRANÇA, Ana C. Qualidade de vida no trabalho: conceitos e práticas nas empresas da sociedade pós-industrial. São Paulo: Atlas, 2003.

Indicadores empresariais de qualidade de vida no trabalho. Tese (Doutorado)- FEA/USP, São Paulo, 1996.

Interfaces da qualidade de vida no trabalho na administração de empresas: fatores críticos da gestão empresarial para uma nova competência. São Paulo: 2001. Tese (Livre-docência)- FEA/USP.

, e, ARELLANO, Eliete Bernal. Os processos de recrutamento e seleção. In: FLEURY, Maria T.L. (org.). As pessoas na organização. São Paulo: Gente, 2002 .; RODRIGUES, A.L..Stress e trabalho. São Paulo: Atlas, 2002.

LOUIS, Meera. Bombayites say they'll never see a stress reducer lovely as a tree. New York: Wall Street Journal (ed.oriental), fev.1, 1999, p. b1.

LUCENA, Maria Diva da S. Planejamento de recursos humanos. São Paulo: Atlas, 1995.

LUFT, Celso Pedro. Minidicionário Luft. São Paulo: Ática, 2001. 
LUZ, José B. da. Dicionário Popular Brasileiro. 35 .ed. Rio de Janeiro: Ed.Civ.Brasileira, 1963.

LYNN, Jacquelyn. Feng shui: can an ancient chinese art help your modern-day office? New York, mar, 2001

MANDRUZATO, Maria L. A grafologia e a empresa: como as empresas estão tirando proveito - aumentando seus resultados. Rio de Janeiro: Qualitymark ed., 1996.

MARCH, Marion D.; McEvers, Joan. Curso básico de astrologia. São Paulo: Pensamento, 1981, v.I.

MARIN, Maysa C. Abordagens avançadas em Recursos Humanos. In: BOOG, Gustavo e BOOG, Madalena (Coord.). Manual de gestão de pessoas e equipes. São Paulo: Gente, 2002.

MARRAS, Jean P. Administração de recursos humanos: do operacional ao estratégico. São Paulo: Futura, 2000.

MARTINS, Gilberto de A.; LINTZ, Alexandre. Guia para elaboração de monografias e trabalhos de conclusão de curso. São Paulo: Atlas, 2000.

MASUNAGA, Shizuto; OSHASHI, Shizuto. Zen-shiatsu: como harmonizar o yin/yang para uma saúde melhor. São Paulo: Pensamento, 1977.

MAXIMIANO, Antonio César Amaru. Teoria geral da administração: da revolução urbana à revolução digital. São Paulo: Atlas, 2002.

Introdução à administração. $5^{\text {a }}$.ed. São Paulo: Atlas, 2000

Introdução à administração. $6^{\mathrm{a}}$.ed. São Paulo: Atlas, 2004.

MINDA, Zetlin. Feng shui: smart business or superstition? New York: Management Review, aug. 1995, p.26.

MC KAY, Betsy. At coke, layoffs all manner of peculiar rumors - vexed, the company is trying to quash of them; the feng shui one is true. New York: Wall Street Journal, oct. 17, 2000, p. A.1. 
MINAYO, Maria Cecília de S. (org.) et al Pesquisa social: teoria, método e criatividade. 16.ed. Petrópolis: Vozes, 1994.

MORGAN, Gareth. Imagens da organização. São Paulo: Atlas, 1996.

MOTTA, Fernando C.P. Masculino e feminino nas organizações. São Paulo: Eaesp. Relatório de pesquisa, n.2, 2000.

1997.

(Coord.) et.al. Cultura organizacional e cultura brasileira. São Paulo: Atlas,

NOGUEIRA, Oracy. Pesquisa social: introdução às suas técnicas. $3^{\text {a }}$.ed. São Paulo: Ed.Nacional, 1975.

OCCHIALINI, Silvana H. Feng shui no trabalho: uma experiência transformadora. In: BOOG, Gustavo e BOOG, Madalena (Coord.). Manual de gestão de pessoas e equipes. São Paulo: Gente, 2002.

OLIVARES, Inês C. e SANTIAGO, Guilherme. Musicoterapia In: BOOG, Gustavo (COORD.) Manual de treinamento e desenvolvimento. São Paulo: Makron Books, 1999

OLIVEIRA FILHO, Kepler de S. Astrologia não é ciência. Disponível em: http://astro.if.ufrgs.br/astrologia.htm. Acesso em: 25 jun. 2004.

PARK, Kil H. (coord). Introdução ao estudo da administração. São Paulo: Pioneira, 2000..

PETRONE, Patrick. Abordagem holística e o caminho espiritual. São Paulo: Summy, 1988.

PUPPIM, Leir Martins. A influência dos aromas naturais na produtividade. Dissertação de mestrado. Iowa: American World University. 2000

RANDALL, E. James; RANDAL, Cindy H. Review of salesperson selection techniques and criteria: a managerial approach. Amsterdan: International Journal of Research in Marketing, dec.1990, v. 7, n. 2,3, p. 81, 15 p.

REDE GLOBO. O poder da astrologia. Disponível em: www.redeglobo6.globo.com/Globoreporter/0,19125, Acesso em: 25 jun. 2004. 
REVISTA CARTACAPITAL. Religiosidade e saúde. São Paulo: Abril, 30 jun. 2004, p. 44-45.

REVISTA EXAME. Melhores e maiores. São Paulo: Abril, jul. 2004, p. 39-182.

REVISTA ISTO É. Saber do outro mundo. São Paulo: Abril, 18 mar. 2004.

RIBEIRO, Anna M.da Costa. Conhecimento da astrologia. Rio de Janeiro: Hipocampo, 1986, 4..ed.

RIBEIRO, Carlos R.M. A empresa holística. São Paulo: Vozes, 1993.

RICHARDSON, Jarry Roberto et al. Pesquisa social: métodos e técnicas. $3^{\text {a }}$.ed. São Paulo: Atlas, 1999.

ROESCH, S. M. A. Projetos de estágio e de pesquisa em administração. São Paulo: Atlas, 1999.

SANTIAGO, Guilherme. Música em Recursos Humanos. In: BOOG, Gustavo e BOOG, Madalena (Coord.). Manual de gestão de pessoas e equipes. São Paulo: Gente, 2002.

SCHRAGE, Michael. Sorry about the profits, boss. my feng shui is off . New York: Fortune, 27 nov. 2000, v. 142.

SELLTIZ e outros. Métodos de pesquisa nas relações sociais. São Paulo: EPU, 1965.

SEVERINO, Antonio J. Metodologia do trabalho científico. 13 ed.. São Paulo: Cortez, 1986.

SCHEIN, Edgar H. Organizational culture and leadership. San Francisco: Josseybass, 1992.

Awareness or organizational culture. Massachusetts: Sloan management review, 1984, v.25, n. 2, p. 3-16.

SMITH, Bob. Graphology in business. New York: HR Focus, v.69, n.3, p.4.

SOARES, Edvaldo. Metodologia científica: lógica, epistemologia e normas. São Paulo: Atlas, 2003. 
STEINER, Dirk D.; GILLILAND, Stephen W. Fairness reactions to personnel selection techniques in France and the United States. Washington: Journal of Applied Psychology. apr. 1996, v. 81, n. 2, p.143, 8 p.

SUNOO, Brenda P. What's with all this feng shui? New York: Workforce, feb. 2000, p. 42.

SPIRI, Sandra R.T. Aromaterapia. In: BOOG, Gustavo e BOOG, Madalena (Coord.). Manual de gestão de pessoas e equipes. São Paulo: Gente, 2002.

SZANTO, Gregory. Astrologia: a escolha da hora certa. São Paulo: Pensamento, 1989.

TACHIZAWA, Takeshy. Metodologia da pesquisa aplicada à administração: a Internet como instrumento de pesquisa. Rio de Janeiro: Pontal, 2002.

THOMAS, Steven L. The write stuff: What the evidence says about using handwriting analysis in hiring. Cincinnati: Advanced Management Journal, v. 66, n. 4, 2001, p. 31, $5 \mathrm{p}$.

TIXIER, Maud. Employers' recruitment tools across Europe. Londres: Employee Relations, v. 18, n. 6, 1996, p.69-80.

TOMLINSON, H. Utensílios de alumínio e doenças: os perigos do uso indiscriminado deste metal. São Paulo: Ícone, 1993.

TUNICK, Britt New investing motto: what's your sign?': when all else fails, why not turn to astrology? New York: The Investment Dealers' Digest, jul., 8, 2002, p. 1.

UNIVERSIDADE DE BRASÍLIA. A ciência contida nos astros. Disponível em: www.unb.br/acs/bcopauta.astrologia1.htm. Acesso em 20 jul. 2004.

VERGARA, Sylvia C. Sobre a intuição na tomada de decisão. Cadernos Ebap. n. 62, Rio de Janeiro: FGV/Ebap, mar. 1993.

VIANNA, Marco Aurélio Ferreira. Estratégia de vida: uma base holística para estratégias de empresas. Recife: 29a . RESEMP, 4 a 9 out. 1992.

WALTON, R. Criteria for quality life. In: DAVIS, L.E., e, CHERNS, A.B. The quality of working life: problems, prospects and state of the art. New York: The Free Press, 1975 
WEBER, Max. Sociologia da burocracia. Trad. Edmundo Campos . Rio de Janeiro: Zahar Ed. 1981.

WEBSTER, Richard. Feng shui para o local de trabalho. São Paulo: Pensamento, 1998.

WEIL, Pierre. Holística: uma nova visão e abordagem do real. São Paulo: Palas Athena, 1990.

Rumo à nova transdisciplinaridade: sistemas abertos de conhecimento. São Paulo: Summus, 1993.

Organizações e tecnologias para o terceiro milênio: a nova cultura organizacional holística. Rio de Janeiro: Rosa dos Tempos, 1995.

WHITE, Suzanne. A nova astrologia. São Paulo: Pensamento, 1986.

WILBER, Ken (Org.). O paradigma holográfico e outros paradoxos: explorando o flanco dianteiro da ciência. São Paulo: Cultrix, 1995.

ZIEMER, Roberto. Mitos organizacionais: o poder invisível na vida das empresas. São Paulo: Atlas, 1996. 
ANEXOS

ANEXO 1 - E-mails enviados para empresas de grande porte

Prezados Senhores,

Meu nome é ELENIR HONORATO VIEIRA. O objetivo deste contato é viabilizar a pesquisa de campo que estou desenvolvendo, para conclusão do doutorado em Administração de Empresas, na FEA/USP.

O tema que estou pesquisando versa sobre Práticas Alternativas em Recursos Humanos. Para tanto, estou em busca de empresas que empreguem um ou mais tipos de práticas alternativas em sua gestão como, por exemplo: astrologia, numerologia, feng-shui, grafologia, essências florais, aromaterapia.

Gostaria de saber se essa empresa utiliza rotineiramente ou utilizou em algum momento qualquer destas práticas para que possa realizar o referido estudo.

Meus contatos por e-mail são elenirhv@uol.com.br ou elenirhv@petrobras.com.br Meus telefones são (11) 97303131 ou (11) 352356549.

Agradeço desde já a atenção em ter respondido a este e-mail.

ELENIR HONORATO VIEIRA 


\section{ANEXO 2 - Pesquisa junto aos gerentes da área de Gestão de Pessoas}

São Paulo, Agosto de 2004.

Senhor(a) dirigente da área de Gestão de Pessoas da empresa:

Estamos enviando, anexo a este e-mail, questionário que foi desenvolvido através da área de Pós-Graduação da Faculdade de Economia, Administração e Contabilidade - FEA, da Universidade de São Paulo, com objetivos estritamente acadêmicos, relacionados à pesquisa na área de Gestão de Pessoas.

O objetivo desta pesquisa é identificar e descrever a utilização, na gestão de pessoas das empresas, de ferramentas consideradas alternativas, ou seja, as práticas não dominantes, cotidianas e comumente empregadas nas organizações, não caracterizadas como cientificamente comprovadas e que, de modo geral, são apresentadas como contendo aplicações mais espiritualistas no sentido de artes adivinhatórias e/ou esotéricas.

Asseguramos o sigilo dos dados aqui informados bem como o caráter estritamente acadêmico de sua utilização. Para dirimir quaisquer dúvidas, pedimos contatar a Sra.Elenir H.Vieira, através do telefone (11) 35236549.

Atenciosamente,

Profa.Dra.Ana Cristina Limongi-França

Orientadora
Elenir Honorato Vieira

Doutoranda 


\section{PESQUISA JUNTO AOS GERENTES DA ÁREA DE GESTÃO DE PESSOAS}

\begin{tabular}{|c|c|c|c|}
\hline \multicolumn{2}{|l|}{ 1. Nome da Empresa } & 2. Nome do Profissional responsável pela Gestão de Pessoas \\
\hline 3. Ramo de atividade & 4. Número de Empregados & $\begin{array}{l}\text { 5. A empresa utiliza uma ou mais ferramentas que considera alternativa? } \\
\text { ( ) SIM (Responda a questão 6) }\end{array}$ & ( ) NÃO (Passe para a questão 7) \\
\hline
\end{tabular}

6. Assinale abaixo, caso a organização faça uso de uma ou mais destas ferramentas e, ao lado, informe a frequência deste uso:

\begin{tabular}{|c|c|c|c|c|c|c|c|c|c|c|c|}
\hline \multirow{3}{*}{$\begin{array}{l}\text { Ferramenta } \\
\text { Utilizada }\end{array}$} & \multicolumn{5}{|c|}{ Freqüência: } & \multicolumn{6}{|c|}{ Programa/área que utiliza: } \\
\hline & \multicolumn{5}{|c|}{$\begin{array}{l}\text { 1. Nunca utilizou esta ferramenta } \\
\text { 2. A empresa trouxe um profissional para ministrar uma } \\
\text { palestra e/ou demonstração da técnica em um evento } \\
\text { 3. Algumas vezes a empresa contratou consultoria ou } \\
\text { técnico para atuar nesta área } \\
\text { 4. Frequentemente a empresa se utiliza desta ferramenta } \\
\text { na gestão de pessoas } \\
\text { 5. Esta ferramenta faz parte da rotina empresarial }\end{array}$} & \multicolumn{6}{|c|}{$\begin{array}{l}\text { 1. Qualidade de Vida no trabalho } \\
\text { 2. Saúde Ocupacional } \\
\text { 3. Recrutamento e Seleção } \\
\text { 4. Treinamento e Desenvolvimento } \\
\text { 5. Avaliação de Desempenho } \\
\text { 6. Outra (citar) }\end{array}$} \\
\hline & 1 & 2 & 3 & 4 & 5 & 1 & 2 & 3 & 4 & 5 & 6 \\
\hline \multicolumn{12}{|l|}{ Astrologia } \\
\hline \multicolumn{12}{|l|}{ Numerologia } \\
\hline \multicolumn{12}{|l|}{ Feng-Shui } \\
\hline \multicolumn{12}{|l|}{ Grafologia } \\
\hline \multicolumn{12}{|l|}{ Essências Florais } \\
\hline \multicolumn{12}{|l|}{ Musicoterapia } \\
\hline \multicolumn{12}{|l|}{ Aromaterapia } \\
\hline \multirow{2}{*}{\multicolumn{12}{|c|}{ 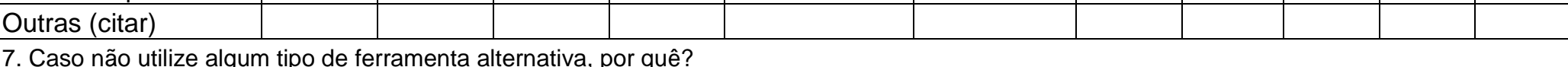 }} \\
\hline & & & & & & & & & & & \\
\hline \multicolumn{6}{|c|}{ ( ) As ferramentas tradicionais suprem as necessidades da organização } & \multirow{2}{*}{\multicolumn{6}{|c|}{ ( ) Outro motivo (cite) }} \\
\hline \multicolumn{6}{|c|}{ ( ) Não acredita ou não considera válidas tais ferramentas } & & & & & & \\
\hline
\end{tabular}

ANEXO 3 - Pesquisa junto a especialistas em ferramentas alternativas 
Este questionário foi desenvolvido, com objetivos estritamente acadêmicos na área de Pós-Graduação da FEA/USP. Solicitamos, pois, alguns minutos de seu tempo, para responder às seguintes questões.

1. Nome

2. Área na qual é especialista:

3. Em que faixa etária você se encontra? ( ) 20 a 29 anos ( ) 30 a 39 anos ( ) 40 a 50 anos ( ) acima de 50 anos

4. Há quanto tempo é consultor/especialista em ( ) Menos de um ano De um a cinco ) De seis a dez Acima de dez empresas? anos 


\section{ANEXO 4 - Pesquisa junto a especialistas}

(Roteiro de Entrevista semi-estruturada e em profundidade)

FEA/SUP

O objetivo desta pesquisa é estritamente acadêmico na área de Pós-Graduação da

Solicitamos, pois, alguns minutos de seu tempo, respondendo às perguntas que seguem:

1. Nome

2. Em qual faixa etária se encontra?

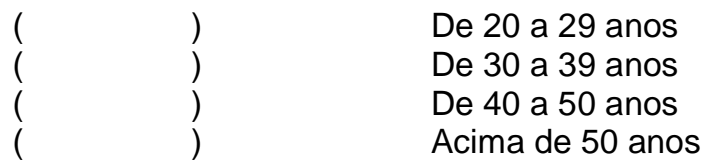

3. Relate sua trajetória profissional.

4. Cite os momentos de crise e os momentos de oportunidade que teve ao longo de sua trajetória profissional.

\begin{tabular}{|l|}
\hline \\
\hline \\
\hline \\
\hline \\
\hline
\end{tabular}


5. Em que momento de sua trajetória profissional passou a se interessar por ferramentas alternativas? Por quais razões?

\begin{tabular}{|l|}
\hline \\
\hline \\
\hline 2 \\
\hline
\end{tabular}

6. Qual(is) ferramenta(s) alternativa utiliza e qual a mais requisitada por empresas?

Para cada uma das ferramentas que citou acima, responda:

7.1. Há quanto tempo aplica esta ferramenta em empresas?
1.
2.
Menos de um ano
Mais de um ano e menos de cinco anos
3. ( ) Mais de cinco anos

7.2. As empresas o(a) contratam:
1. $(\quad)$
Especificamente para que você aplique esta ferramenta na gestão de pessoas.
2. ( ) Para o desenvolvimento de um trabalho relacionado à gestão de pessoas e, durante ele, você aplica esta ferramenta por opção, pois já havia negociado previamente com a direção da empresa.
3. ( ) Para o desenvolvimento de um trabalho relacionado à gestão de pessoas e, durante ele, você aplica esta ferramenta se julgar necessário, mesmo sem conhecimento prévio da direção da empresa.
4. ( ) Para o desenvolvimento de um trabalho em gestão de pessoas, mas nem todas as empresas concordam que você utilize esta ferramenta durante o trabalho.
Se assinalou as alternativas $1, \mathrm{e} 2$, em quais programas de gestão de pessoas você utiliza?

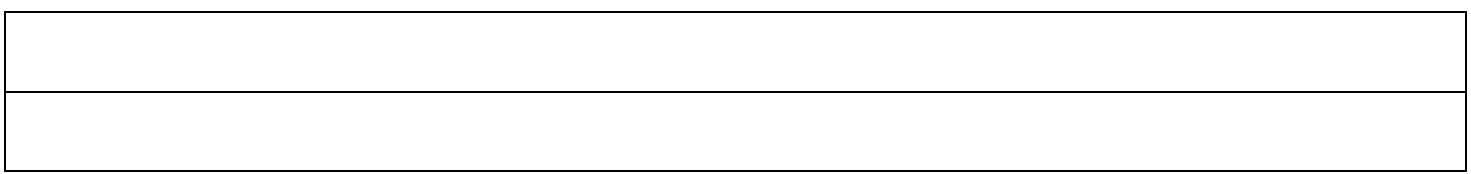

7.3. Você considera que os resultados obtidos com a aplicação desta ferramenta são:

$\begin{array}{lll}1, & (\quad) & \text { Positivos em todas as vezes } \\ 2 . & (\quad) & \text { Positivos na maior parte das vezes } \\ 3 . & (\quad) & \text { As vezes é positivo e outras vezes negativo } \\ 4 . & (\quad) & \text { É negativo na maior parte das vezes } \\ 5 . & (\quad) & \text { É negativo todas as vezes }\end{array}$


Justifique sua resposta:

\begin{tabular}{|l|}
\hline \\
\hline 2
\end{tabular}

7.4. Quais as vantagens desta ferramenta quando comparada a ferramentas tradicionais?

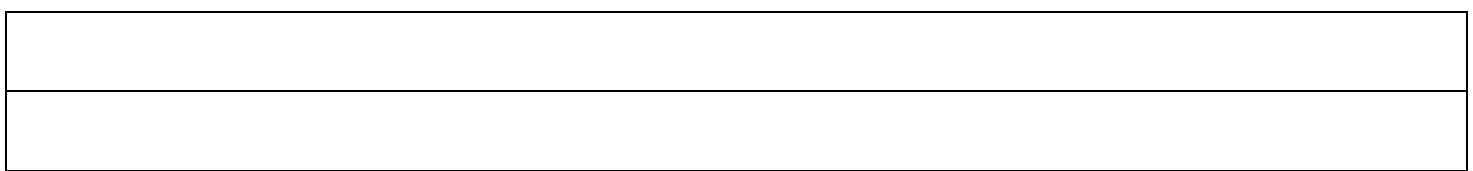

7.5. Quais as desvantagens desta ferramenta quando comparada a ferramentas tradicionais?

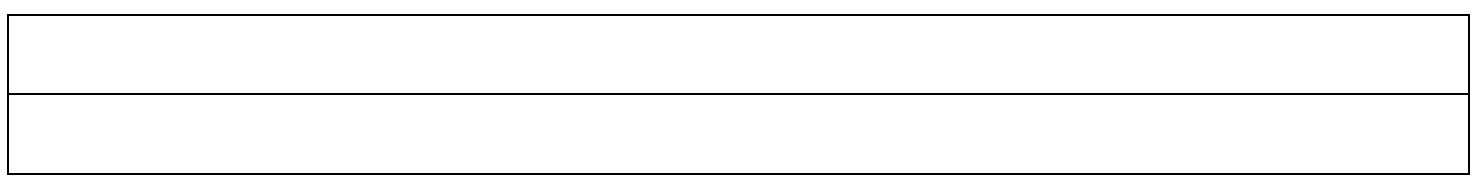

7.6. Como aplica esta ferramenta em empresas?

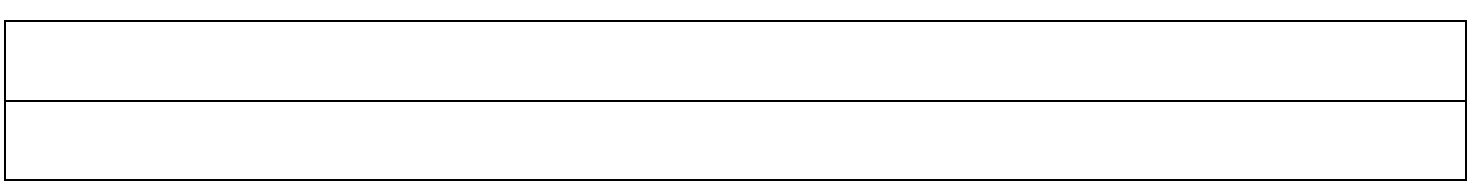

7.7. Descreva como é o grau de aceitação da direção da área de gestão de pessoas das empresas para esta ferramenta.

7.8. Descreva como é o grau de aceitação ou reprovação dos empregados das empresas, quando utiliza esta ferramenta.

8. Você identifica alguma relação entre a visão de mundo e de sociedade e dos valores propostos nas organizações nas quais presta serviços e a aceitação/utilização de ferramentas alternativas?

( ) SIM ( ) NÃO

Justifique sua resposta. 
9. Você identifica alguma relação entre a utilização de ferramentas alternativas e a motivação dos empregados? ( ) SIM

Justifique sua resposta.

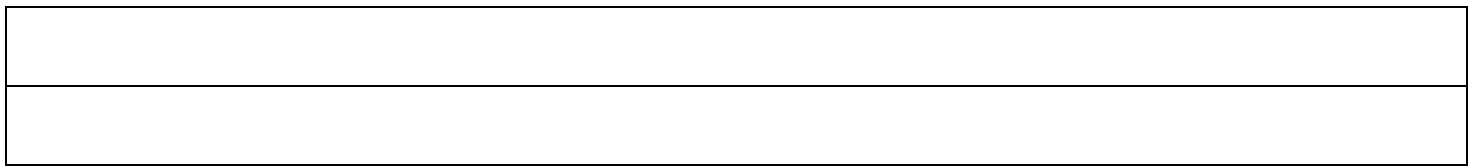

10. Você identifica alguma relação entre a utilização de ferramentas alternativas e a gestão de qualidade de vida no trabalho? ( ) SIM ( ) NÃO

Justifique sua resposta.

11. Quais setores empresarias mais utilizam os seus serviços:

Serviços de :Transporte ( ) Públicos ( ) Tecnologia e Computação ( ) Telecomunicações ( )

Comércio: ( )

Terceiro Setor ( )

Indústria: ( ) alimentos, bebidas e fumo ( ) automotivo ( ) Confecções e têxteis

( ) Construção ( ) Eletroeletrônico ( ) Farmacêutico ( ) Material de Construção

( ) Mecânica ( ) Mineração ( ) Papel e Celulose ( ) Plásticos e Borracha

( ) Siderurgia ( ) Química e Petroquímica ( ) Siderurgia e Metalurgia

12. Qual o tamanho das empresas que mais utilizam os seus serviços:
( ) Pequeno porte
( ) Médio Porte
( ) Grande Porte

13. A empresa o contrata para qual atuar junto a que público (se mais de um relacione em ordem crescente:

( ) Alta Direção $\quad(\quad)$ Média Gerência $\quad(\quad ） \quad$ Empregados
administrativos

14. Observações complementares: 


\section{ANEXO 5 - Pesquisa junto aos dirigentes que atuam na área de gestão de pessoas e utilizam} práticas alternativas

(Roteiro de Entrevista semi-estruturada e em profundidade)

FEA/SUP.

O objetivo desta pesquisa é estritamente acadêmico na área de Pós-Graduação da Solicitamos, pois, alguns minutos de seu tempo, respondendo às perguntas que seguem:

1. Nome do Gestor:

2. Em qual faixa etária se encontra?

\begin{tabular}{|c|c|c|}
\hline 1. & ) & De 20 a 29 anos \\
\hline 2. & ) & De 30 a 39 anos \\
\hline 3. & ) & De 40 a 50 anos \\
\hline 4. & ) & Acima de 50 anos \\
\hline
\end{tabular}

3. Há quanto tempo atua como gerente na área de pessoas nesta empresa?

\begin{tabular}{|c|c|c|}
\hline 1. & ) & Menos de um ano \\
\hline & ) & Mais de um ano e menos de cinco anos \\
\hline & ) & Mais de cinco anos \\
\hline
\end{tabular}

4. Formação escolar
1.
2.
3.
4.

$\begin{array}{ll}( & \\ ( & \\ ( & \end{array}$
Nível médio
Nível superior
Pós-Graduação (especialização/MBA)
Mestrado e/ou doutorado

5. Relate a história da empresa, desde o momento de sua criação até o momento atual, enfatizando aspectos que possam ter contribuído para a utilização de ferramentas alternativas na empresa. 
6. Cite os momentos de crise e os momentos de oportunidade que a empresa teve ao longo de sua história.

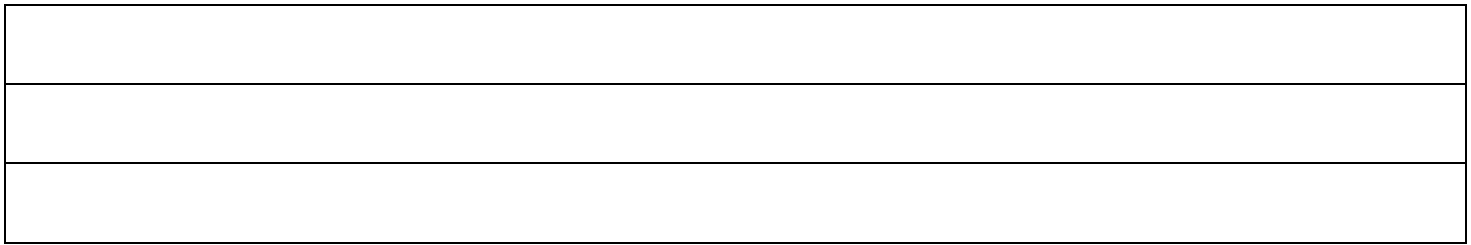

7. Em que momento da história da empresa, esta passou a utilizar ferramentas alternativas? Por quais razões?

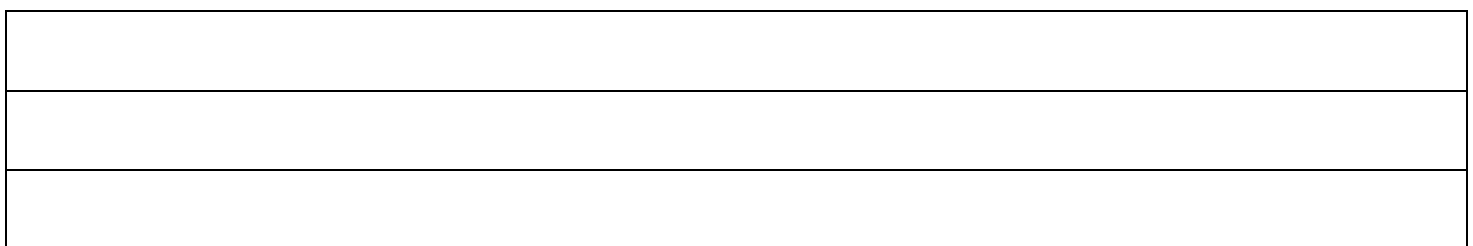

8. Qual(is) ferramentas alternativas é(são) utilizada(s), com que freqüência e em quais programas institucionais ou áreas ocorre esta aplicação?

Para cada ferramenta que utiliza:

8.1. Quais os resultados obtidos com a aplicação desta ferramenta?

8.2. Quais as vantagens desta ferramenta quando comparada a ferramentas tradicionais? 
8.3. Quais as desvantagens desta ferramenta quando comparada a ferramentas tradicionais?

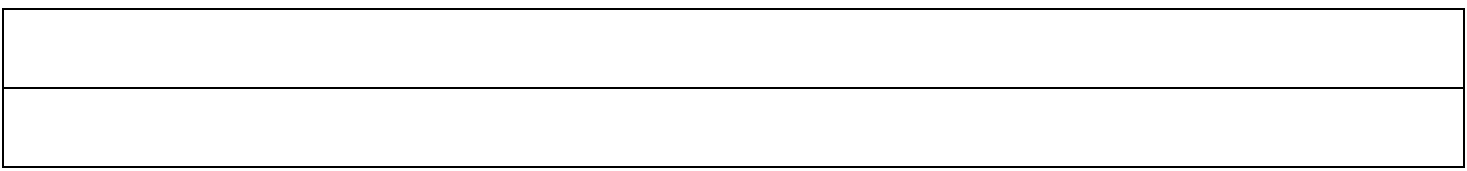

8.4. Em quais situações aplica esta ferramenta?

8.5. Como aplica esta ferramenta na empresa?

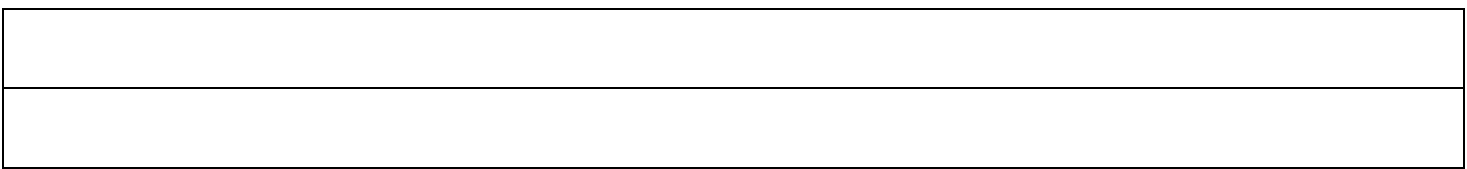

9. Você identifica alguma relação entre a visão de mundo e de sociedade e dos valores propostos nesta organização e a aceitação/utilização de ferramentas alternativas? Se respondeu SIM, explique esta relação.

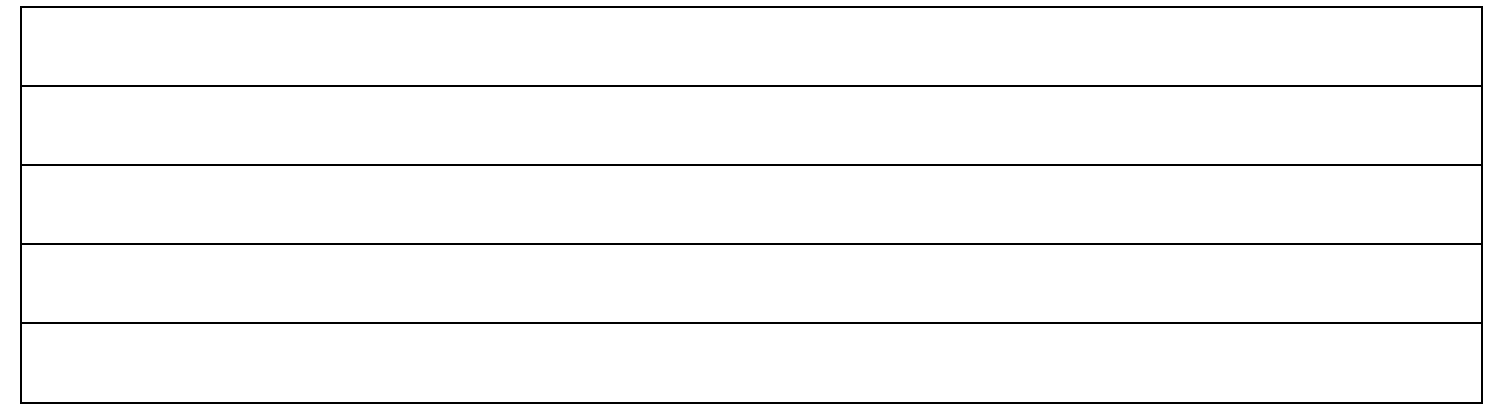

10. Descreva o grau de aceitação ou discordância do corpo gerencial para estas ferramentas?

11. Descreva o grau de aceitação ou discordância dos empregados da empresa, quando se utilizam ferramentas alternativas? 
12. Existe alguma relação entre a utilização de ferramentas alternativas e motivação dos empregados? ( ) SIM Não Justifique.

13. Existe alguma relação entre a utilização de ferramentas alternativas e a gestão da qualidade de vida no trabalho? ( ) SIM ( ) Não Justifique.

14. Informações complementares:

\begin{tabular}{|l|}
\hline \\
\hline \\
\hline \\
\hline \\
\hline \\
\hline
\end{tabular}




\section{ANEXO 6 - Previsão astrológica entregue semanalmente à empresa e afixada no Mural para consulta de todos os empregados}

\section{CLIMA DE 07 a 13/03/05 - Utilizando Conhecimentos de Astrologia e Cosmologia - por Vera Fernandes}

Participamos da Unidade e contemos em nós a totalidade. Como Microcosmo que somos estamos inter-relacionados às Configurações planetárias, especialmente do nosso Sistema Solar. Essa influência no Homem se traduz em 12 energias, que chamamos doze casas. Esse trabalho destina-se a informar essas influências para que possam ser utilizadas conscientemente.

Podemos, então, usufruir dos movimentos de benesses energéticas, e nos prevenir nos momentos difíceis. Como o positivo atrai o positivo, podemos usar os momentos favoráveis, para iniciar movimentos importantes, escolhendo-os conscientemente. Cada signo solar é conduzido por uma energia em especial:

Preto - Leão ; Branco - Gêmeos ; Amarelo - Virgem ; Prata - Peixes ; Dourado - Áries ; Rosa - Aquário ; Verde - Touro ; Celeste - Câncer ; Vermelho - Sagitário ; Azul Libra ; Marrom - Capricórnio ; Violeta - Escorpião.

Observe especialmente os dias em que a sua cor está positiva, para usufruir, ou negativa, para evitar momentos complicados e também usufrua quando a Lua estiver da cor do seu signo solar, especialmente se estiver Cheia.

\section{Sugere-se não usar roupas nas cores negativas}

OBS.: LUA FORA DE CURSO - A Lua fica sem condução, como que perdida no Céu; nesses momentos ficamos sujeitos a falha de atenção, o que pode causar pequenos aborrecimentos, como perder um documento, chaves do carro, perder-se no caminho, perder o fio da meada de algum assunto, etc., e tudo o mais que pode causar uma falha de atenção, inclusive, conforme a configuração cósmica e filtro da Lua, uma batida de carro. Então, sugere-se nesses períodos fazer uma coisa de cada vez e procurar não se irritar.

07/03 - Segunda - Lua Minguante Rosa. Temos Rosa e Vermelho em desarmonia, com Lua Rosa. Tende haver brigas, desentendimentos e atitudes impulsivas. Sugerese levar o dia na rotina, sem decisões importantes. Não é recomendado tratar de temas relacionados com Seguros, Máquinas e Equipamentos, atenção a qualquer possibilidade de problema com maquinário. Bom para dormir com a cabeça ao Sul, para usufruir do amanhecer do dia seguinte. Cor sugerida Dourado ou Azul (jeans) 
08/03 - Terça - Lua Minguante Rosa fica fora de curso das 12:29 até 21:33 hs quando entra em Peixes. Temos Verde, Violeta e Prata em harmonia até 06:00 hs. Desde $0: 15 \mathrm{hs}$, até o amanhecer temos um momento muito especial, pois a Lua enfatiza a harmonia de Júpiter e Netuno desses tempos, para a noite entrar em Peixes (cujo regente é Netuno). Se você acordar ao amanhecer, coloque uma intenção de usufruir dessa benesse de Prata, Verde e Violeta, que pode jogar Luz sobre seu caminho para acura. Bom para tratamentos em geral. Bom para mudanças na rotina, com possibilidade de simplificação, bom para assuntos estratégicos. Procure observar as idéias que vêm à sua mente ao acordar. Bom para desenvolver essas idéias. Cor sugerida Verde ou Violeta.

EMPRESA - Bom pela manhã para assuntos em geral

CHEGANDO - IDEM

09/03 - Quarta - Lua Minguante Prata, Temos dias neutro, que tende ser tranqüilo com fluidez nos assuntos. Bom especialmente para piscianos usarem o Prata para resolver quaisquer problemas . Cor sugerida Prata.

10/03 Quinta - Lua Nova Prata fica fora de curso a partir das 13:45 até 23:04hs. Temos Preto e Violeta em desarmonia das 10:00 até 20:00hs. Procure evitar as Horas Pretas e Violetas para iniciar movimentos importantes e sugere-se não tratar de assuntos importantes ligados ao financeiro, compras, orçamento, cobrança. Não é dia indicado para tratar de objetivos e metas, nem para planejamentos em geral. Após as 20:00hs temos Dourado e Rosa em harmonia. Bom para eventos, celebrações. Cor Sugerida Prata

11/03 Sexta Lua Nova Dourada. Dia neutro, bom para tratar de assuntos que pedem calma e concentração. A Lua Dourada é benéfica para tratar de assuntos ligados a promoções, eventos, marketing, propagandas. Cor Sugerida Dourado ou Verde.

12/03 Sábado - Lua Nova Dourada fica fora de curso a partir de 17:14 até o fim do período. Hoje o Violeta está negativo por todo o período. O Rosa negativo até 16:00hs e o Vermelho a partir das 10:00hs. Atenção para não entrar em clima de ressentimentos e brigas, nem se envolver nas emoções dos outros. Procure manter o centramento e observar o que acontece sem envolver-se. Cor Sugerida Verde.

13/03 Domingo - Lua Nova Verde. Temos o Vermelho fracamente negativo no período. Sugere-se evitar horas Vermelhas para iniciar movimentos importantes, bem como não colocar-se em situações ou locais de risco. Não é recomendado tratar de assuntos importantes referentes a seguros, testes de máquinas e equipamentos, atenção ao dirigir. Cor Sugerida Verde. 